UNITED STATES DEPARTMENT OF THE INTERIOR

Ray Lyman Wilbur, Secretary

GEOLOGICAL SURVEY

w. C. Mendenhall, Director

Professional Paper 161

\title{
QUATERNARY GEOLOGY OF MINNESOTA AND PARTS OF ADJACENT STATES
}

BY

\section{FRANK LEVERETT}

WITH CONTRIBUTIONS BY

FREDERICK W. SARDESON

Investigations made in cooperation with the MINNESOTA GEOLOGICAL SURVEY

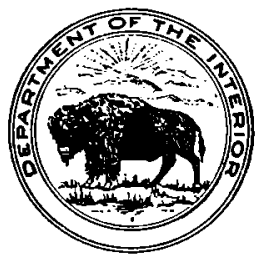

UNITED STATES

GOVERNMENT PRINTING OFFICE

WASHINGTON : 1932

For sale by the Superintendent of Documents, Washington, D. C. 



\section{CONTENTS}

Abstract

Introduction . . . .

Scope of field work

Earlier reports

Outline of the Pleistocene series of glacial deposits

The oldest or Nebraskan drift............. Aftonian soil and Nebraskan gumbotil........

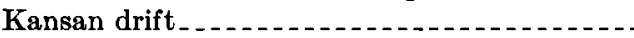

Yarmouth beds and Kansan gumbotil. .......

Pre-Illinoian loess (Loveland loess) ...........

Erosion in the second (Yarmouth) interglacial stage

Illinoian drift and Iowan drift..............

Sangamon soil and Illinoian gumbotil.......

The main deposit of loess............

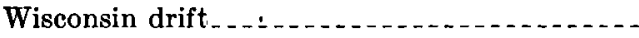

The great glacial lakes .................

Physical features and rock formations of Minnesota.... Outline of the geography and geology of Minnesota....

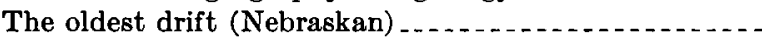

Distribution and character........

Effect on outlying drainage

Kansan drift . .

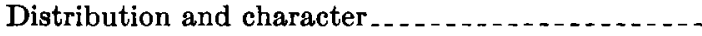

Effect on outlying drainage

Illinoian or old red drift.

Iowan drift

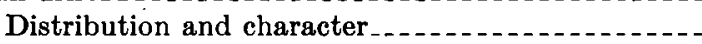

Probable Iowan drift west of Des Moines lobe of Wisconsin drift.

Outlying gravel plains

Pebble concentrate and weathered zone on Iowan drift.

Loess of upper Mississippi Valley .

Loess west of the Des Moines lobe...........

Relative age of loess and Iowan drift.........

Wisconsin red drift.

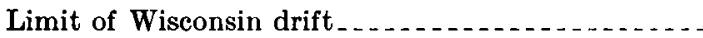

St. Croix morainic system

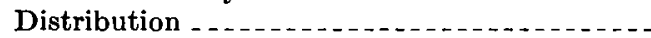

Morainic topography

Structure and constitution of the drift........

Outwash from St. Croix morainic system ......

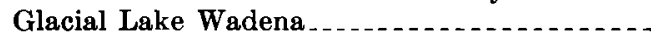

Features on inner border of St. Croix morainic

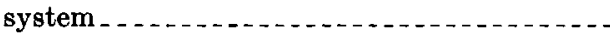

Eskers ............

Sandy outwash plains . .

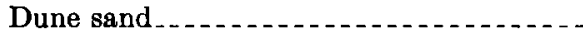

Striae . . . . . . . . . . . . . . . . . . . . .

Weak moraines between St. Croix and Mille Lacs

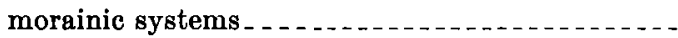

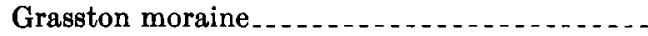
General features....................... Outwash deposits...................... Contemporary drainage. . . . . . . . . Eskers

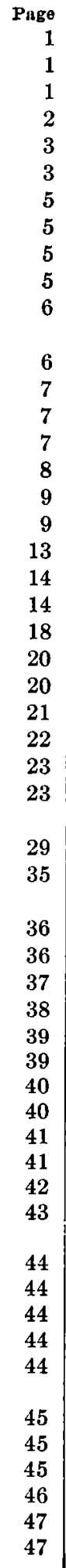

Page

Wisconsin red drift-Continued.

Weak moraines, etc.-Continued.

Beroun moraine . .

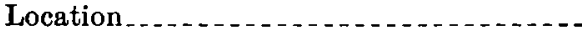

Topography ...........................

Constitution of the drift in relation to rock

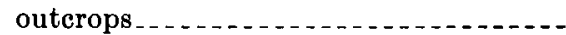

Striae . . . . .

Ground moraine inside of Beroun moraine

Mille Lacs morainic system . . . . . . . .

Location

Topography ....

Character of the drift.......................

Rock outcrops and striae. . . . . . . . . . .

Outwash ..............

Associated till plains . .

Eskers.......

Plain between Mille Lacs morainic system and Kimberly moraine.

Outlets of Mille Lacs Lake.

Kimberly moraine . ...................

Moraines of the Superior ice lobe in Minnesota and correlative Patrician moraines. ...............

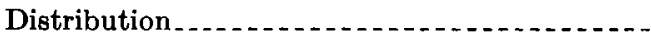

General characteristics......................

Outwash and glacial drainage from the Superior ice tobe.

Glacial lakes connected with the Superior ice lobe Glacial Lake St. Louis . . . . Glacial Lake Nemadji . . . . . . . . . . . . . . Glacial Lake Duluth. . . . . . . . . . . . . . . .

Late Wisconsin moraines of the Patrician ice in northeastern Minnesota......................

Wisconsin gray drift (Des Moines lobe)

General features.................................

Bemis moraine in South Dakota...............

Bemis moraine in southwestern Minnesota

Bemis moraine in Iowa . . . . . . . . . . . . . . . . .

Bemis morainic belt on east side of Des Moines lobe.

Bemis moraine and limits of young gray drift north of Grantsburg sublobe.

Keewatin drift south of Mesabi iron range........

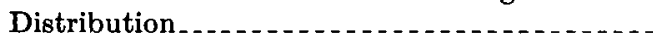
Relation to Patrician drift. Relation to Superior ice lobe...........

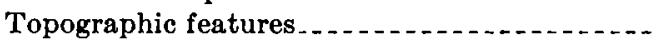
Character of Keewatin drift.......... Probable place in Wisconsin stage . ........ Lake Aitkin.

Outwash and glacial drainage on east side of Keewatin ice sheet.

Altamont morainic system . . . . . . . . . Name. . . . . . . .

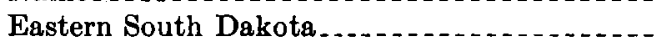
Southwestern Minnesota ................ Iowa. . South of Grantsburg sublobe............. 
Wisconsin gray drift-Continued.

Altamont morainic system-Continued.

North of Grantsburg sublobe............

Outwash from Altamont morainic system .....

Gary moraine . . . . . . . . . . . . . . . .

Extent . . . . . .

Topography

Structure of the drift

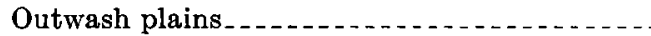

Grantsburg sublobe of Wisconsin gray drift, by F. W.

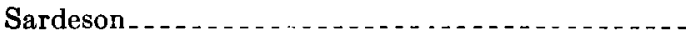

General relations . . . . . . . . . . . . . . . . . .

Extramorainic till sheet............................

The first or Rush Lake morainic system .......... Pine City moraine . . . . . . . . . . . . . .

Cambridge moraine . . . . . . . . . . . . . .

Isanti moraine $\ldots \ldots$

Harris moraine . . . . . . . . . . . . . . . . . . . .

Topography .............................. Composition ...........

Glacial striae . . . .

Associated outwash and glacial drainage.....

Intermorainic plains ........................

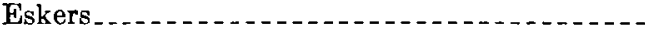

Crow River morainic system

Anoka moraine..............

Loretto moraine . .

Delano moraine............................

Montrose moraine . . . .

Topography

Composition. . . . .

Associated outwash and glacial drainage . ....

Associated ground moraine

Glacial river terraces................................

Terraces of St. Croix Valley .

Terraces of Mississippi Valley . . . . . . . . .

Terraces of Minnesota Valley ............

Other river terraces

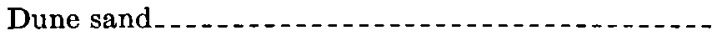

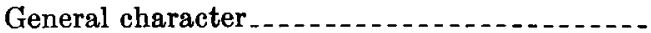

Mode of deposition

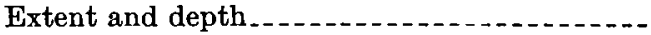

Minor moraines of Wisconsin gray drift in Minnesota

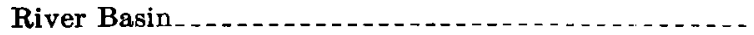

Fairmont morainic system

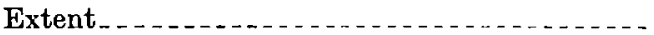

Topographic features....................

Character of the drift.

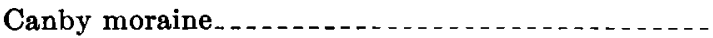

St. James morainic system $\ldots$

Extent . . . . .

Topographic features......................

Character of the drift. . . . . . . . . . .

Features of inner-border district. ..........

Relation of glacial Lake Minnesota to St.

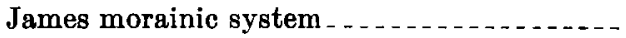

Marshall moraine . . . . . . . . . . . . . . . . . .

Extent . . . . . . . . . . . . . .

Topographic features . . . .

Character of the drift. ...................

Outwash and border drainage.
Minor moraines of Wisconsin gray drift, etc.-Contd.

Marshall moraine-Continued.

Outwash and glacial drainage in Minnesota

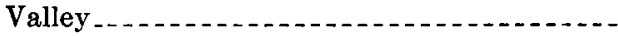

Features of inner-border district. . . . . . . .

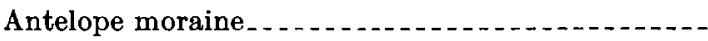

Extent . . . . . .

Topographic features

Character of the drift

Outwash and border drainage

Moraines and associated features between Antelope

moraine and Minnesota Valley ...............

Moraines of Red River Basin

Bigstone morainic system..........

Extent . . . . . . . . .

Topographic features.

Character of the drift . . . . . . . .

Outwash and border drainage

Inner-border features .......................

Moraines between Bigstone morainic system and glacial Lake Agassiz......

Distribution

Topographic features..........

Character of the drift. . .

Outwash and border drainage. . . .........

Erskine moraine and its probable continuations....

Extent . . . . . . . . -

Topographic features..........

Character of the drift.........

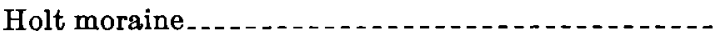

Minor morainic ridges in Kittson County, Minn.--

Glacial Lake Agassiz ... . . . . . . . . . . . . . . .

Early observations and interpretations..........

Character and extent of present studies............

Ponding north of Mesabi iron range prior to the

formation of Lake Agassiz .

Lake Milnor, a preliminary stage of glacial Lake

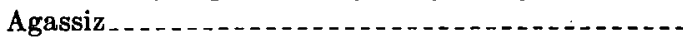

Lake Milnor beach

Lake Milnor outlet

Ice-border lake (pre-Herman beach stage) east of

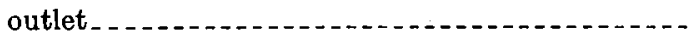

River Warren, the outlet of Lake Agassiz

So-called deltas of Lake Agassiz . . . . . . . . . . .

Herman shore lines . . . . . . . . . . . . . . .

General features.......

Features of the west shore..................

Eastern shore in Minnesota..................

Lower members of the Herman series of beaches

Character of the Herman shore lines. . . . . . .

Norcross shore lines. . . . . . . . .

Tintah shore lines.

Campbell shore line. ...

McCauleyville shore line........................

Lower shore lines in Minnesota...............

Classes of land on the bed of Lake Agassiz . . .

Pleistocene fossils.

Development of present Mississippi drainage

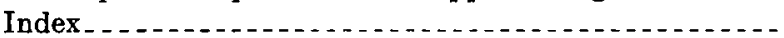

Page

102

102

103

103

103

104

104

104

105

105

105

106

107

108

110

111

111

113

114

114

115

115

116

116

117

118

119

119

119

120

121

122

123

123

123

126

127

127

129

132

133

134

134

136

137

139

139

140

141

144

147 


\section{ILLUSTRATIONS}

Plate 1. Map of northern Minnesota showing surficial deposits. . . . . . ............ In pocket.

2. Map of southern Minnesota showing surficial deposits . . . . . . . In pocket.

3. Map of Minnesota showing the relations of the moraines of the Keewatin ice to those of the Patrician ice and of the Superior lobe of the Labrador ice........... In pocket.

4. $A$, Wisconsin gray till of the Keewatin ice overlying Wisconsin red till of the Patrician; $B$, Wisconsin till of the Keewatin ice overlying stony till of the Patrician ice..

5. Map of Lake Agassiz outlet............ In pocket.

Figdre 1. Map of Minnesota showing extent of glacial ice sheet, directions of ice movement, and shores of glacial lakes.

2. Map of Minnesota showing altitudes above sea level.

3. Physiographic provinces of Minnesota and adjacent regions.........................

4. Geologic map of Minnesota and adjacent region, showing distribution of rock formations _...............................

5. Sketch map of Iowa showing surface distribution of the five sheets of glacial drift.

6. Sketch map showing extent of Iowan and Wisconsin drifts in southwestern Minnesota and eastern South Dakota. .......

7. Map showing extent of Iowan and Wisconsin drifts in northwestern Iowa

8. Map of the northeast township of Sioux County, Iowa, showing drainage development on each side of the west border of the Iowan drift.

9. Drainage deflections in northwestern Iowa due to Iowan ice invasion

10. Map showing relations of drainage in Gillett Grove and Logan Townships, Clay County; Iowa, to the outer terminal moraine of the Wisconsin drift.
Figure 11. Map showing relations of moraines of the Des Moines and Dakota ice lobes near their junction in the northern part of eastern South Dakota. ..............

12. Map showing relations of moraines of the Des Moines and Dakota ice lobes near their junction in the southern part of eastern South Dakota..............

13. Drumlinoid ridges in Wadena County, Minn.

14. Outlet of glacial Lake Norwood across

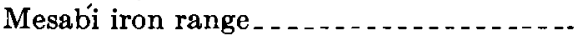

15. Outlet and southern part of glacial Lake Agassiz basin, showing Milnor, Herman, and Campbell shore lines...............

16. Map of southern part of glacial Lake Agassiz basin, showing glacial moraines, shore lines, and outlet of the glacial lake......

17. Map of shore lines, dune areas, and moraines at west side of glacial Lake Agassiz basin

18. Map of shore lines and moraine at east side of glacial Lake Agassiz basin . ........

19. Map of moraines and western shore lines of glacial Lake Agassiz, Cass and Traill Counties, N. Dak.

Page

20. Map of moraines and eastern shore lines of glacial Lake Agassiz, Clay and Norman Counties, Minn.

21. Map of moraines and western shore lines of glacial Lake Agassiz, Grand Forks and adjoining counties, $N$. Dak

22. Map of moraines and shore lines of eastern part of Lake Agassiz basin, Polk and adjacent counties, Minn...............

23. Map of western shore lines of glacial Lake Agassiz near the international boundary in North Dakota and Manitoba.........

24. Generalized profiles showing successive stages of St. Anthony Falls from Soldier Ravine to the present falls below Nicollet Island. 



\title{
QUATERNARY GEOLOGY OF MINNESOTA AND PARTS OF ADJACENT STATES
}

\author{
By Frank Leverett
}

With contributions by Freperick W. SARDEson

\begin{abstract}
ABS'TRACT
The area here described embraces the entire State of Minnesota and adjacent parts of Wisconsin, Iowa, and North and South Dakota, which have a glacial history closely bound up with that of Minnesota. This area is one of considerable complexity of glacial movements in the last or Wisconsin glacial stage, as well as a succession of glaciations in the preceding stages. A considerable part of this history has been presented in previous reports.

An introductory chapter of the present report gives an outline of earlier reports, of glacial gathering grounds and ice lobes, and of the Pleistocene series of glacial deposits, loess, etc. The physical features of Minnesota are briefly discussed in a separate chapter.

The Nebraskan or oldest drift and the probable effect of the Nebraskan glaciation on outlying drainage take a brief chapter, and so do the Kansan stage of glaciation and its attendant drainage. The old red drift of probable Illinoian age is next considererl. This is followed by a discussion of the Iowan drift and of drift of supposed Iowan age exposed west of the Des Moines lobe of Wisconsin drift, including outlying gravel outwash in the Big Sioux River drainage basin. The relation of the Iowan drift to the Illinoian is indicated as not definitely determined.

The Sangamon soil and weathered zone, developed on the Illinoian drift, and a pebbly concentrate developed on the Iowan drift are next discussed, together with the loess deposit that overlies them.

The limits of the red drift of middle Wisconsin age are outlined, and the several moraines or morainic systems, eskers, till plains, striae, and outwash plains are described.

The gray drift of late Wisconsin age is the uppermost deposit over a large part of Minnesota, and its description takes up the major part of this report. The features of the Minnesota or Des Moines lobe and those of two sublobes on its east side are described separately. The Grantsburg sublobe is discussed by F. W. Sardeson.

The interpretation of the morainic succession on the east side of the Minnesota lobe differs radically from that given in the reports of the Geological and Natural History. Survey of Minnesota. It has been found that the border of the ice lobe receded from the central part of the State toward the Minnesota and Red River Valleys instead of away from these valleys toward the central part. The numbering of moraines in the earlier reports as sixth, seventh, eighth, ninth, etc., is the reverse of their order of development as interpreted by the present writers.

The time relation of the late Wisconsin gray drift to the middle Wisconsin red drift is clearly shown by their relative positions, the gray drift overlapping the red. The part of the later drift that lies south of the Mesabi iron range has a
\end{abstract}

reddish color because of incorporation of material from the range, but it also carries the limestone pebbles characteristic of the gray drift, derived from outcrops in Manitoba.

The southern parts of the loops of some of the moraines within the Red River drainage basin were deposited in the waters of glacial Lake Agassiz. These parts have very weak expression compared with the parts of the same morainic belts formed on the land, yet the moraines are in large part traceable.

Evidence of ponding of moderate extent prior to the beginning of Lake Agassiz is found along the north side of the Mesabi iron range and also at the south end of the Red River drainage basin, in Minnesota and North Dakota.

In the description of the features of glacial Lake Agassiz the distribution and altitude relations of the higher beaches, or those connected with the southern outlet through the Minnesota or River Warren valley, receive chief attention, though notes on lower beaches connected with an eastward outlet or outlets in Canada are presented. Numerous data showing the direction and rate of tilting of several of the beaches are given. The complexities of drainage at the south end of the lake are described and illustrated by topographic maps. A brief statement as to classes of land in the bed of Lake Agassiz is given.

The history of the Falls of St. Anthony as worked out by Winchell and later more fully by Sardeson is briefly outlined to show its value as a geologic chronometer.

\section{INTRODUCTION} SCOPE OF FIELD WORK

The area here described embraces the State of Minnesota and adjacent parts of Wisconsin, Iowa, and North and South Dakota, which have a glacial history closely bound up with that of Minnesota.

In the spring of 1906 the writer, assisted by Rollin T. Chamberlin, began the study of the drift deposits bordering the driftless area in Minnesota and neighboring parts of Wisconsin and Iowa. Pebble classifications were made at numerous points in the district, to determine variations from place to place and at different horizons, and to learn the rock formations represented in the drift deposits and the probable sources of drift material. The general character of the oxidation and leaching under various conditions of texture and of topographic situation was also studied. This study was carried through the field seasons of 1906 and 1907. A preliminary report was then prepared covering the work of the two years in 
the three States. The publication of this report was withheld pending investigation of a wider region, but it was some years before the study was thus extended. In 1909, 1910, and 1911 the writer investigated the district bordering Lake Superior, in Minnesota, Wisconsin, and Michigan. The results of these studies have recently been published. ${ }^{1}$

Considerable field work was done in Minnesota in 1912 along the border of the Wisconsin (latest) drift and on the outlying older drift formations in the southwestern part of the State and in neighboring parts of North and South Dakota. In this work the writer was assisted by Clifton S. Corbett. Some field work was also done, with the assistance of Earl $\mathbf{R}$. Preston, along the Mesabi range in northern Minnesota. The writer also worked to some extent with Frederick W. Sardeson in a special study of the drift in four quadrangles centering at Minneapolis and St. Paul, the results of which appear in the MinneapolisSt. Paul folio (No. 201) of the Geologic Atlas of the United States, prepared by Sardeson. The writer worked in a similar way with Sardeson in 1913 in the study of the drift deposits in four quadrangles in western Minnesota, which are described in the Herman-Morris folio (No. 210), also prepared by Sardeson.

The funds for the work done down to 1912 by the writer and his assistants and by Sardeson were provided by the United States Geological Survey, but from 1912 to 1915 aid in field work was given by the Minnesota Geological Survey. During 1913, 1914, and 1915 Sardeson and the writer extended the study of the Pleistocene deposits over the remainder of the State. The field has been revisited by the writer in later years down to 1923 , in order to clear up certain matters of interpretation and correlation. In May, 1921, the writer joined James H. Lees, of the Iowa Geological Survey, in completing the tracing of the Altamont moraine of the Des Moines ice lobe through northern Iowa. In 1923 several weeks was spent in northwestern Wisconsin in a special study of the preWisconsin drifts.

In addition to the geologic folios cited above three bulletins have been published by the Minnesota Geological Survey. Bulletin 12, prepared by the writer, deals with the soils and surface features of the northwest quarter of the State. Bulletins 13 and 14, prepared with Sardeson's assistance, deal, respectively, with the northeast quarter and southern half. Each of these bulletins includes a section on the climatic conditions of Minnesota, prepared by U. G. Purssell, director of the Minnesota section of the United States Weather Bureau. These bulletins treat mainly of the

\footnotetext{
${ }^{1}$ Leverett, Frank, Moraines and shore lines of the Lake Superior Basin: U. S. Geol. Survey Prof. Paper 154, pp. 1-72, 1929.
}

agricultural conditions in relation to the several classes of drift deposits, but discuss the geologic features in an incidental way.

The purpose of the present report is to set forth the geologic history as interpreted from the surficial deposits of Minnesota and adjacent regions. There is perhaps no part of the United States in which the complexity of the glacial movements is better illustrated than in Minnesota. This State also falls within the area affected by a northward differential uplift, which came in the final stages of the glacial epoch. Significant data are here obtainable in regard to the amount and direction of the tilting, as it affected the shore lines of the glacial lakes.

The present report embraces much material collected by Sardeson, aside from the portions that appear under his name, and it is with pleasure that the writer expresses here his appreciation of the aid and stimulation received from his associate during the prosecution of the work.

\section{EARLIER REPORTS}

In publications of the Geological and Natural History Survey of Minnesota under the direction of N. H. Winchell, appearing at intervals from 1872 to 1900 , a large amount of information as to moraines and other glacial features is presented, and a nearly complete mapping of moraines through most of the counties is shown. It has been found, however, that certain correlations of moraines need revision. This is true of some correlations where but little correction is required in the position or course of the moraine.

A report by George W. Ralph, State drainage engineer, entitled "Topographical survey of Minnesota, 1906," contains a large amount of data on swamp lands in much of the northern half of the State. Several other reports of the State Drainage Commission deal mainly with water resources. Under cooperative arrangement between the State drainage engineer and the Director of the United States Geological Survey, topographic surveys of a considerable number of quadrangles have been made. A map with 10 -foot contours of a district embraced between Red Lake and the international boundary, from Lake of the Woods to Rainy Lake, made by a special survey under the Department of the Interior for the purpose of planning drainage ditches, is of much value in furnishing data on the altitude of shore lines of glacial Lake Agassiz.

A report on the geology and underground waters of the southern third of Minnesota ${ }^{2}$ embraces the results of work by Hall and Sardeson in assembling

${ }^{2}$ Hall, C. W., Melnzer, O. E., and Fuller, M. L., Geology and underground waters of southern Minnesota: U. S. Geol. Survey WaterSupply Paper 256, 406 pp., 1911. 
and interpreting well records, etc., carried on for some years after the work of the Geological and Natural History Survey, under the direction of N. H. Winchell, had been discontinued, and of supplementary work by M. L. Fuller and O. E. Meinzer, of the United States Geological Survey, each of whom spent a season in rounding out the study of wells and water supplies in the southern part of the State in cooperation with the Minnesota State Board of Health. The report includes a map showing the thickness and character of the surface deposits of southern Minnesota. It follows the Winchell maps in the delineation of moraines but gives the distribution of the loess as worked out later by Sardeson and by Leverett.

GIACIAL GATHERING GROUNDS AND ICE LOBES

The glacial gathering grounds that pertain to the last or Wisconsin stage of glaciation are more easily determined than those of earlier stages, the records of which are largely buried under the later deposits, but there were probably essentially the same gathering grounds in earlier glacial stages.

In the differentiation of glacial gathering grounds in North America three names have been appliedLabrador, Keewatin, and Cordilleran. The Labrador and Keewatin ice fields together formed the Laurentide area of glaciation. The Labrador portion of the ice field covered eastern Canada and the northeastern part of the United States as far west as the Mississippi Valley. The Keewatin portion covered central Canada and the part of the United States between the Mississippi and Missouri Valleys, with a slight extent outside these limits. In the last glaciation the ice extended only to central Iowa, but in two earlier glaciations it extended to central Missouri and into eastern Nebraska and Kansas. The Cordilleran ice field occupied much of Canada in and west of the Rocky Mountains, but did not extend far south into the United States.

In 1913 it was announced by Tyrrell ${ }^{s}$ that in the waning part of the Wisconsin glacial stage ice radiated from the district of Patricia, in northwestern Ontario, between the Labrador and Keewatin ice fields. It seems probable that at an earlier time in the Wisconsin stage than that noted by Tyrrell there was. a definite ice movement southward from the Patricia district into Minnesota and across the western part of the Superior Basin into Wisconsin.

The basis for differentiating the ice sheets as having the several centers of dispersion is found in the radiating bearings of the glacial striae and the transportation of drift material in directions accordant with these bearings. There is, however, very much

${ }^{3}$ Tyrrell, J. B., The Patrician Glacier south of Budson Bay : Twelfth Internat. Geol, Cong., Canada, Compt. rend., pp. 523-534, 1013. (i7605-32-32-2 complexity both in drift transportation and in the bearings of the striae, which seems to indicate some shifting of centers of dispersion with attendant, changes in the direction of ice movement in the course of a single stage of glaciation. The complexity becomes still greater if the several stages of glaciation are taken into account.

In Minnesota the shiftings of the ice movement in the Wisconsin glacial stage are shown with exceptional clearness. It is found that the Patrician ice movement culminated and had begun to wane before the Keewatin movement had reached its culmination. (See pl. 3.) Similarly the culmination of the Lahrador part of the ice sheet, with movement into central Illinois, antedated the culmination of the Patrician part, with movement into Minnesota and Wisconsin. As indicated in an earlier paper, ${ }^{4}$ the phenomena suggest the westward growth of an ice sheet that started on the Labrador peninsula and moved southwestward into central Illinois. This growth westward favored a later southward movement from the Patricia district and a still later southward movement from Manitoba into the Dakotas, Minnesota, and Iowa. By the time of the Patrician culmination the part of the ice sheet farther east had shrunk materially, its limits being at either Union City or the Missisinawa morainic system in Indiana and Ohio. At the culmination of the Keewatin movement of the Wisconsin stage the limits in the east appear to have been at the Port Huron morainic system, which encircles the southern edges of the Huron and Ontario Basins. The Labrador part of the ice sheet at that time, however, seems to have taken full possession of the Superior Basin by an advance into the west end, which had been vacated by the Patrician part. In the final phase of the Wisconsin glaciation the ice in the Labrador district seems to have persisted longer than that in the Patricia district. The Labrador ice figures in the present report only so far as it touched Minnesota. The deposits of the Patrician ice here discussed lie west of the Chippewa ice lobe in Wisconsin.

\section{OUTLINE OF THE PLEISTOCENE SERIES OF GLACIAL DEPOSITS}

The Pleistocene deposits include a complex series of till sheets and associated sand and gravel beds, separated by soil and nonglacial beds, formed in long intervals of deglaciation between stages of glaciation. The States bordering the upper Mississippi River, especially Minnesota and Iowa, have an exceptionally full exhibit of the deposits and thus offer very favorable ground for their study. (See fig. 1.)

- Leverett, Frank, Pleistocene deposits of Minnesota and adjacent districts [abstract]: Geol. Soc. America Bull., vol. 2i, pp. 68-69, 1916. 
The outlines of the drift sheets of this region that have been given in reports and textbooks for the last 30 years have represented five drifts, representing five distinct glacial stages, with intervening relatively warm interglacial stages. In some outlines the last or Wisconsin stage has been subdivided into early and late $W$ isconsin, though it has been commonly held that

sidered a probable correlative of the Illinoian drift, representing the Keewatin part of the ice sheet in the third glacial stage, as indicated more fully below.

The names of the drift sheets in the Mississippi drainage basin have been shifted so often as to procluce confusion without giving a fully satisfactory nomenclature. At first it was proposed to name the oldest drift of the se-

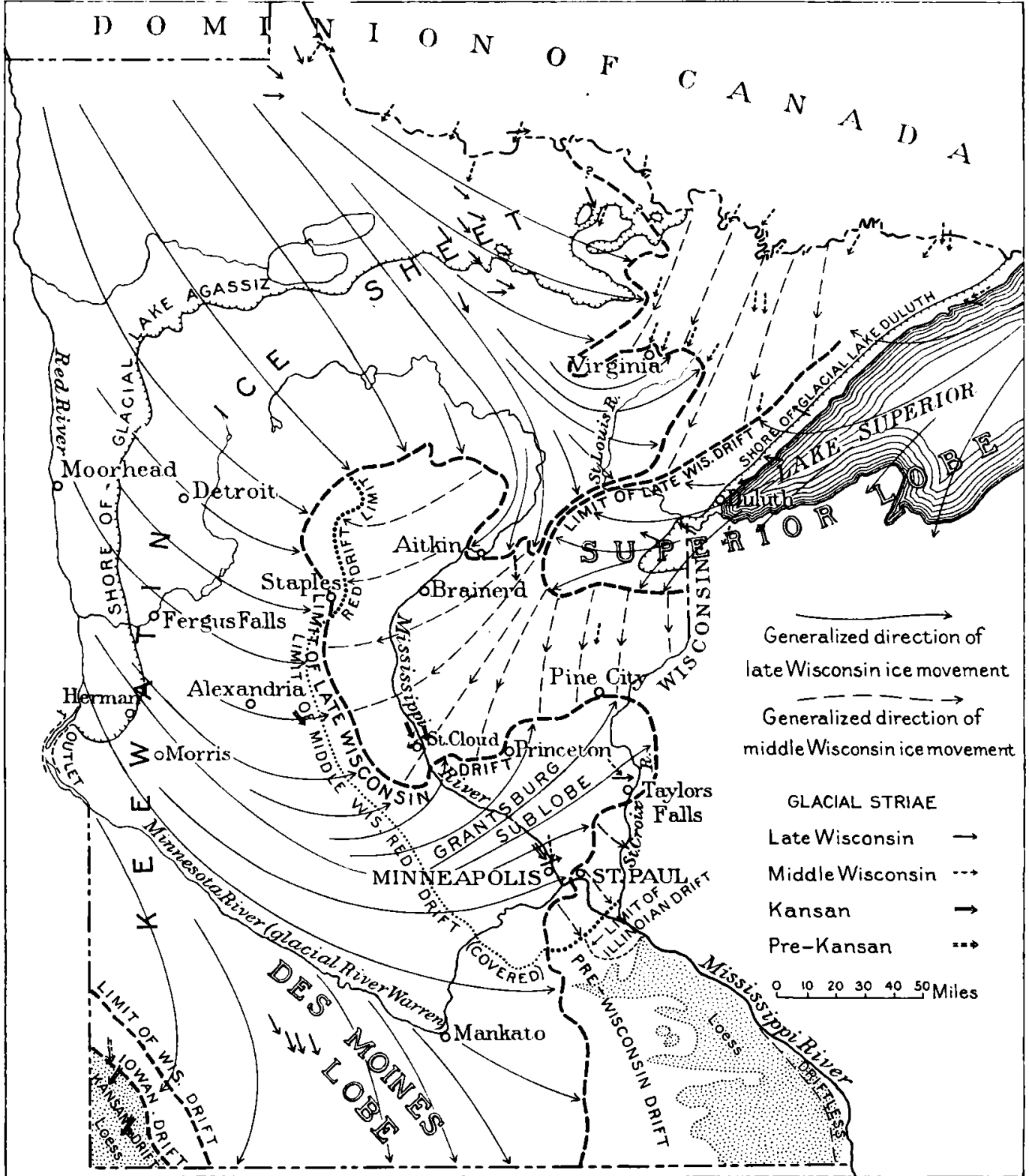

Figurw 1-Map of Minnesota showing extent of glacial ice sheet, directions of ice movement, and shores of glacial lakes there was no intervening warm stage between these subdivisions. The first, second, third, and last drift sheets are all well-defined deposits exposed or identified over a wide extent of country, but the Iowan drift, which has been classed between the third and the last drift sheets, is a deposit of rather scanty exposure, and its reference to a separate glacial stage has been, with some geologists, a matter of doubt. By them it is con- ries Kansan and the s e cond, or the one above it, "East Iowan," so o n contracted to Iowan. ${ }^{5}$ But because of the discovery of a third drift in eastern Iowa, where only two drifts had been previously recognized, it was thought advisable to call this third drift Iowan and the second drift Kansan. ${ }^{6}$ It is now better understood that the second drift is the principal drift sheet of Iowa and therefore the one that might more appropriately be called Iowan, as originally proposed. The lowest drift, originally named Kansan, was called sub-Aftonian and also preKansan, for a number of years; but in 1910 Shimek ${ }^{\text {' de- }}$ scribed it as Nebraskan. $T h$ is name, however, seems to the writer of questionable application, as the drift has scarcely any exposure in Nebraska, either in outcrop or as a surface sheet, being almost completely covered by the second drift. Meantime, in 1906, Chamberlin and Salisbury ${ }^{8}$ introduced a new name for a very old drift in the eastern United States, calling it Jerseyan, a term which has pertinence

${ }^{B}$ Chamberlin, T. C., in Geikie, James, The great lce age, 3d ed., pp. 753-775, 1894; Jour. Geology, vol. 3, pp. 270-277, 1895.

- Chamberlin, T. C., Jour. Geology, vol. 4, pp. 872-876, 1896.

' Shimek, Bohumil, Science, new ser., vol. 31, pp. 75-76, 1910; Gcol. Soc. America Bull., vol. 20, p. $408,1910$.

${ }^{8}$ Chamberlin, T. C., and Salisbury, R. D., Geology, vol. 3, pp. 383$384,1906$. 
for that district, as the drift is widely exposed in New Jersey and its characteristics were worked out there. The Illinoian or third drift of the eastern part of the Laurentide area of glaciation and the Wisconsin or youngest drift have not been subjected to such changes of names as the other drifts. The Illinoian seems appropriately named because of its wide exposure in the State of Illinois. The Wisconsin (originally termed "East Wisconsin") also seems pertinently named, because it was in Wisconsin that this drift was first differentiated from earlier ones.

The oldest or Nebraskan drift.-West of the driftless area and the Mississippi River the oldest drift is largely covered by the second, or Kansan, drift. It may be represented by scattered erratics found beyond the limits of the Kansan drift in Kansas and Missouri. In its extreme extension the ice may have reached into Kentucky beyond the limits of later drifts and deposited the erratics that have recently been discovered there. The deposits in southeastern Missouri below the mouth of the Missouri River may also pertain to the oldest drift. The erratics and patches of drift in Kentucky and southeastern Missouri were deposited by the Labrador part of the ice sheet and so may prove to be of Jerseyan age. Those in central and western Missouri and in Kansas were left by the Keewatin ice and may thus be Nebraskan. The Keewatin ice may also have been the source of deposits of black till east of the Mississippi River in western Illinois. Some of the limestone pebbles in that till may have come from formations in Manitoba. If the oldest drift is demonstrated to include all these outlying deposits, the first glaciation must have been the most extensive of the several Pleistocene stages. The characteristics and degree of preservation of this drift are discussed on pages 14-19.

Aftonian soil and Nebraskan gumbotil.-The soil which had been developed on the oldest drift sheet before the second drift was laid down was called Aftonian by Chamberlin. ${ }^{8}$ At that time numerous occurrences of buried soil had been noted by $\mathrm{W} \mathrm{J} \mathrm{McGee}$ in eastern Iowa, and exposures near Afton, Iowa, were examined in a field conference which Chamberlin and McGee had been holding prior to the naming of the interglacial soil. At the type locality, as well as in other places in that general region, there is a conspicuous development of gumbotil ${ }^{10}$ at the top of the subAftonian (Nebraskan) till, which constitutes impressive evidence of prolonged interglacial action. Kay has accordingly urged that the gumbotil be given a

\footnotetext{
O Chamberlin, T. C., Jour. Geology, vol. 3, p. 272, 1895.
}

${ }^{10}$ The term "gumbotil" was proposed by G. F. Kay (Sclence, new ser., vol. 44 , pp. 637-638, 1916) to apply to the tenacious gummy deposits formed an the surface of the old tills (Nebraskan, Kansan, and Illinoian), which are regarded as largely the product of chemical weathering of the upper parts of these tills in interglacial time. See Jour. Geology, vol. 28, pp. 89-125, 1920, for a fuller description. leading place in solving problems pertaining to the length of the several interglacial stages in which it has been developed.

Certain bone-bearing gravel deposits in the Missouri River Valley have been referred by Calvin ${ }^{11}$ and Shimek ${ }^{12}$ to the Aftonian, but as Kay ${ }^{13}$ has recently questioned the evidence that the bone-bearing gravel is Aftonian, its age and its relation to the ice sheet are yet to be determined.

Kansan drift.-Since 1896 the drift deposited in the second stage of glaciation, when the ice sheet reached the northeastern part of Kansas, ${ }^{14}$ has been known as Kansan. This drift forms a nearly complete cover of the oldest drift in the district west of the Mississippi River and is the upper till sheet in southern and western Iowa, northern Missouri, and adjacent parts of Kansas, Nebraska, South Dakota, and Minnesota. Its exposure in Minnesota is in the southeastern and southwestern parts of the State. Its characteristics are set forth on pages 20-22. The Kansan drift in the glaciated district east of the Mississippi Valley is largely covered by later till sheets.

Yarmouth beds and Kansan gumbotil.-At Yarmouth, Iowa, a well section was found to embrace thick deposits of peaty material between the Kansan drift and the overlying Illinoian drift. The peat deposit has a thickness of 15 feet and is underlain by about 12 feet of silty deposits containing wood and other organic material, which seem referable to this interglacial stage. These beds of peat and silt, which have been named Yarmouth by the writer, ${ }^{15}$ were developed between the withdrawal of the Kansan ice sheet and the culmination of the Illinoian ice sheet and thus seem to be restricted to this interglacial stage. It is unfortunate that the type locality is of a sort not open to study, except by borings.

The gumbotil developed on the Kansan till is widely exposed outside the limits of the Illinoian drift and has been found beneath the Illinoian drift in south eastern Iowa. Where it underlies the Illinoian drift it is commonly 6 to 8 feet thick and is thus fully as impressive as the Yarmouth peat bed in giving evidence of a long interglacial interval. It seems to be to a large degree the product of chemical weathering, as determined by Kay and Pearce, ${ }^{16}$ and thus to have required a long time for its development. Gumbotil probably includes considerable material that was de-

1 Calvin, Samuel, Geol. Soc. America Bull., vol. 20, pp. 133-152, 341-356, 1909; vol. 22, pp. 207-216, 1911 ; Iowa Acad. Scl. Proc., vol. 17, pp. 177-180, 1910 .

12 Shimek, Bohumil, Science, new ser., vol. 28, p. 923, 1908 ; vol. 31, pp. 75-76, 1910 ; vol, 33, p. 467,1911 ; vol. 34, p. 28,1911 ; Geol. Soc. America Bull., vol. 20, pp. 399-408, 1909 ; vol, 22, p. 730, 1911.

${ }^{13} \mathrm{Kay}$, G. F., Geol. Soc. America Bull., vol. 35, pp. 71-74, 1924.

14 Jour. Geology, vol. 4, pp. 872-876, 1896.

${ }^{15}$ Leverett, Frank, Jour. Geology, vol. 6, pp. 238-243, 1898; U. S. Geol. Survey Mon. 38, pp. 119-124, 1899.

1e Kay, G. F., and Pearce, J. N., The origin of gumbotil : Jour. Geology, vol. 28, pp. 89-125, 1920. 
posited on the till in interglacial time from atmospheric dust. In many exposures examined by the writer the major part of the gumbotil seems not to have been derived from the till but to have been deposited on it. But even if the major part was contributed from the atmosphere, the time required for the development of gumbotil of the thickness found on the Kansan till could not have been brief, for the entire deposit is chemically weathered. It differs in this respect from the overlying loess of southern Iowa, parts of which show but slight chemical weathering. The loess thus seems to have been laid down more rapidly than any atmospheric material included in the gumbotil.

Pre-Illinoian loess (Loveland loess).-A deposit of typical loess has been found under the Illinoian drift in western and southwestern Illinois. Its occurrence in Rock Island County, in western Illinois, on the border of the Mississippi Valley, was brought to notice in an early report by the writer, ${ }^{17}$ and its fossils were identified by W. H. Dall as of similar species to those found in the surface loess of that region. A similar deposit was noted by the writer later in Monroe and Randolph Counties, southwestern Illinois.

The Loveland formation of western Iowa and northwestern Missouri is also a reddish loesslike silt loam that underlies the buff loess of that district. This deposit was interpreted by early students to be a phase of the loess, but Shimek, ${ }^{18}$ who called it Loveland, considered it a water deposit. He thought it was deposited by water accompanying the melting of the Kansan ice sheet. But later Kay ${ }^{10}$ determined that the Kansan drift had become greatly eroded before this deposit was laid down and that it has no genetic relation to the Kansan glaciation.

The age of the Loveland loess was not definitely fixed by Kay in this report, but he subsequently published two papers interpreting the Loveland deposit to be post-Illinoian. ${ }^{20}$ This interpretation was based on the occurrence of two deposits of loesslike character over the Illinoian drift, the lower being correlated by him with the Loveland. This lower deposit, however, seems to be present in only a few places and is not general and widespread, like the upper one, and its significance remains to be determined. In these papers Kay failed to consider the question of correlating the Loveland with the pre-Illinoian loess.

\footnotetext{
${ }^{17}$ Leverett, Frank, The Illinois glacial lobe: U. S. Geol. Survey Mon. 38, pp. 114-115, 1899.

${ }^{18}$ Shimek, Bohumil, Iowa Geol. Survey Ann. Rept. for 1909, pp. $371-375,1910$.

${ }^{10}$ Kay, G. F., Iowa Geol. Survey Ann. Rept. for 1919-20, pp. xvilxviii, 1921.

${ }^{20}$ Kay, G. F., Loveland loess : Post-Illinoian, pre-Iowan in age : Science, new ser., vol. 68 , pp. $482-483$, Nov. 16,1928 ; The relative ages of the Iowan and Illinoian drift sheets: Am. Jour. Sc1., 5th ser., vol. 16, pp. 497-518, December, 1928.
}

The present writer ${ }^{21}$ accordingly called attention to this pre-Illinoian loess as the probable equivalent of the Loveland loess. Kay ${ }^{22}$ made a partial acceptance of this correlation and suggested that part of the Loveland may be pre-Illinoian and part post-Illinoian. As no separation of the Loveland loess into two distinct parts has been noted, it seems to the present writer more probable that the Loveland is to be correlated in the main with the pre-Illinoian loess.

In 1925, in a field conference held by G. F. Kay, Paul MacClintock, E. R. Apfel, and the writer, exposures of what seem likely to be the Loveland loess were found near Sheldon, Iowa, between the Kansan till and an overlying drift sheet, which, as indicated below, seems to be the correlative of the Iowan till of northeastern Iowa. This may have the same age as the pre-Illinoian loess of western Illinois. This loess near Sheldon had suffered considerable leaching prior to the deposition of the overlying till and also rested on the eroded surface of the Kansan drift.

Erosion in the second (Yarmouth) interglacial stage.-Although the peat, muck, gumbotil, and loess deposits between the Kansan and Illinoian drifts afford impressive evidence of the long duration of the second or Yarmouth interglacial stage, they have only local exposures and are no more significant than the amount of erosion the Kansan drift suffered in this stage, which is widely evident. The relative amounts of erosion displayed by the Kansan and Illinoian drifts where they are exposed side by side are not only striking features in the field but are also clearly shown by the topographic maps published by the United States Geological Survey. Thus the maps of quadrangles in the Kansan drift area, such as those of the Atlanta and Kahoka quadrangles, Missouri, and the Knoxville, Milo, and Creston quadrangles, Iowa, may be compared with those of quadrangles within the Illinoian drift area, such as the Milan, Edgington, Macomb, Canton, Vermont, Goodhope, and Laharpe quadrangles, Illinois. In the Kansan area there are much dissected valley slopes a quarter to half a mile wide; in the Illinoian area the bluffs are much steeper and the valleys relatively smaller. On the Kansan drift there are preserved only narrow strips of the original drift plain; on the Illinoian about half of the original plain is preserved. A comparison of this sort serves to make it evident that the duration of the Yarmouth interglacial stage was markedly longer than the time since the Illinoian stage of glaciation. The places are relatively few where the peat and gumbotil are exposed for study, but the amount of erosion is

${ }^{2 \pm}$ Leverett, Frank, Loveland loess ; pre-Illinoian, pre-Iowan in age : Sclence, new ser., vol. 69, pp. 551-552, May 24, 1929.

${ }^{22} \mathrm{Kay}$, G. F., Significance of post-Illinoian, pre-Iowan loess : Science, new ser., vol. 70, pp. 259-260, Sept. 13, 1929. 
open to study everywhere. The Kansan drift is also much more deeply oxidized and leached than the Illinoian. In Minnesota the comparison of Kansan and Illinoian drifts is confined to a small area southeast of St. Paul, and that of Kansan and Iowan drifts to narrow strips in the southeastern and southwestern parts of the State, as shown on pages 22-30. Neither of these areas is as yet topographically mapped. The field studies, however, show that the Kansan drift was markedly eroded and weathered before the later drifts were brought in.

Illinoian drift and Iowan drift.--The Illinoian drift, so named because of its wide exposure in the State of Illinois, was in large part the product of an ice sheet that moved southwestward from the Labrador peninsula, across the Great Lakes district, to the vicinity of the Mississippi River, in western Illinois and southeastern Iowa. Its margin forms part of the east border of the driftless area in Wisconsin and Illinois. The drift north of the driftless area was brought in from the Patricia district, to the north, and a considerable part of it is referred tentatively to the Illinoian stage of glaciation. The same drift has a slight exposure in Washington and Dakota Counties, eastern Minnesota. The Iowan drift may have been deposited in this same glacial stage, as the product of ice coming in from the region west of Hudson Bay. The Iowan drift appears to include a strip of drift exposed in southwestern Minnesota and neighboring parts of Iowa and South Dakota. It is the third drift of that district, the Kansan and pre-Kansan drifts being found beneath it.

In the Illinoian drift and to a lesser degree in the Iowan drift terminal moraines, kames, and other constructional features are preserved. The slopes of the ridges and knolls, however, are worn down to a marked degree, compared with the erosion of similar features on the Wisconsin or latest drift.

The writer has recently published an estimate of the probable time involved in the several Pleistocene glacial and interglacial stages, ${ }^{22 a}$ in which it is found that the Illinoian and Iowan as well as Wisconsin glaciations all fall in the last third if not in the last fourth of the glacial epoch and are separated by interglacial stages much shorter than those between the preceding glacial stages.

Sangamon soil and Illinoian gumbotil.-On the Illinoian drift there is a widespread dark soil containing much organic material which has been buried under a deposit of loess. It seems to have been developed in a cool, damp climate that followed the withdrawal of the Illinoian ice sheet. This soil the writer proposed to call Sangamon soil, because it is conspicu-

22a Relative length of Pleistocene glacial and interglacial stages: Leverett, Frank, Science, new ser., vol. 62, pp. 193-195, 1930. ously developed and was early noted in the drainage basin of the Sangamon River, in western Illinois. ${ }^{23}$ In a few places peat of considerable depth is found between the Illinoian till and the loess. Gumbotil 2 to i) feet thick is also present where conditions favored its development and preservation. The black soil, peat, and gumbotil are restricted to parts of the surface of the Illinoian till where drainage conditions were poor. The well-drained portions have the ordinary brownish soil, with leached subsoil and oxidation to ciepths of 15 to 25 feet or more. In eastern Minnesota the black soil is rare, and the leached and weathered condition is common.

On the Iowan till there is a pebbly concentrate, which is described below (pp. 23-24, 28, 36, 37, 38).

The main deposit of loess.-At the time the Iowan drift was first brought to notice by Calvin and his assistants on the Iowa Geological Survey, about 1894, the main deposit of loess was regarded by many geologists as a water deposit. ${ }^{24}$ The Iowa geologists thus correlated it with the Iowan drift as an outwash in the eastern part of Iowa and called it Iowan loess. The present writer accepted this name and has used it in some previous discussions of the deposit, though he was long ago convinced that it is a wind deposit and not outwash from an ice sheet. In places the loess begins with a very thick border at what has been considered by the Iowa geologists to be the limit of the Iowan drift, and this led to the view that it was kept off the Iowan drift area because of the presence of the ice sheet during the loess-depositing stage. These geologists were, however, aware that in other places the borders of the two deposits do not thus coincide. It is now a question whether the main deposition of this loess took place at or near the time when the ice sheet was present or was separated from it by an interval of some length marked by the development of the pebbly concentrate above noted.

It appears that the deposition of loess preceded the Wisconsin glaciation by an interval of sufficient length for it to become somewhat leached and weathered but not deeply so. This interval has been termed by the writer ${ }^{25}$ the Peorian. The loess is thus pre-Peorian and post-Sangamon. This loess has been referred by Alden and Leighton ${ }^{26}$ to the early part of the Peorian interval. The selection of a permanent name may perhaps be left to the future, when the time relations of the deposit are more fully understood. The extent and characteristics of the loess are set forth below (pp. 36-39).

${ }^{23}$ Leverett, Frank, Jour. Geology, vol. 6, pp. 171-181, 1898.

as Iowa Geol. Survey Ann. Rept. for 1894, pp. 170-171; idem for 1895 , pp. $66-69$, idem for 1896 , pp. $40,86-88,174-176,234-238$.

${ }^{26}$ Leverett, Frank, Jour. Geology, vol. 6, pp. 244-249, 1898.

${ }^{26}$ Alden, W. C., and Leighton, M. M., Iowa Geol. Survey, vol. 26, pp. $157-158,1917$. 
Wisconsin drift.-The Wisconsin drift is the product of the latest glacial stage and is relatively little eroded and weathered. In the early part of this glacial stage the ice sheet moved southwestward from the Labrador peninsula across the Great Lakes region into central Illinois. This is generally known as the Labrador ice movement. At that time the ice sheet appears not to have extended into the region north and west of the driftless area of the upper Mississippi Valley. The moraines formed in this early part of the Wisconsin stage, the Shelbyville, Champaign, Bloomington, and Marseilles morainic systems, are perceptibly more eroded than those farther north and west and have been generally classed as the product of an early $W$ isconsin substage.

The writer ${ }^{27}$ some years ago called attention to evidence that the ice sheet which started in the Wisconsin glacial stage on the highlands of the Labrador peninsula gradually expanded westward, so that in the midst of this stage its highest part was farther west than in early Wisconsin time. There came as a result a movement more directly southward into the Great Lakes region, and the development of morainic systems more or less concentric with the south ends of their basins, from New York westward into Wisconsin. This may be termed the Patrician movement, as distinguished from the earlier or Labrador ice movement, the district of Patricia, west of James Bay, in northwestern Ontario, being within the area of ice dispersion. At this time the outer moraine of the Green Bay lobe of eastern IVisconsin was formed, and this appears to be correlative with the Tekonsha moraine in Michigan. It may be correlated also with the St. Croix or outermost strong morainic belt of Wisconsin red drift of western.Wisconsin and eastern Minnesota.

Still later in the Wisconsin glacial stage there was a vigorous ice movement from the district of Keewatin (from a tract now partly within the present northern limits of the Province of Manitoba) into Minnesota, Iowa, and the Dakotas, which deposited. the Wisconsin gray drift. The Des Moines lobe, in Minnesota and Iowa, and the James River or Dakota lobe, in the Dakotas, pertain to this movement, which is generally known as the Keewatin ice movement. Its drift overlaps the red Wisconsin drift in Minnesota and is easily distinguished from the red drift by the paler color and the presence of the limestone fragments from Manitoba. The overlap in eastern Minnesota is at least $7 \check{0}$ miles. The ice that deposited the red drift seems thus to have melted back to so marked a degree that it allowed the ice from the area west of Hudson Bay to spread freely in Minnesota. The correlative morainic system of the Great Lakes region appears to be the Port Huron

${ }^{n}$ Leverett, Frank, Geol. Soc. America Bull., vol. 27, pp. 68-69, 1916. system. While the ice of the eastern district was barely filling the basins of Lake Ontario, Lake Huron, and Lake Superior, that of the western district was at or near its culminating position. The features of the Minnesota field seem more consistent with this interpretation than with that of Warren Uphanı, as presented in the reports of the Minnesota Geological and Natural History Survey, that the ice which brought in the red drift was still covering nearly all of the red-drift area at the culmination of the western ice movement which brought in the gray drift. The former ice can not have been in contact with the western lobe, for lines of glacial drainage, as indicated fully in the detailed discussion, lead from the graydrift border across the red-drift area in a way which leaves no doubt that that part of the red-drift district. was free from ice. The shrinking of the eastern part of the ice field was probably due to the smaller amount of snowfall in that region, rather than to a moderation of the climate.

Still later, in the waning part of the Wisconsin glaciation, when the Keewatin ice front had receded, there seems to have been renewed activity in the Patrician district, with a spreading of the ice northward and westward, as determined by Tyrrell, ${ }^{28}$ into the district just vacated by the Keewatin ice. After this, according to Tyrrell, the Patrician ice melted away from the district and the Labrador ice spread westward as far as the Hayes River. It thus appears probable that the Labrador peninsula was the ranishing ground of the Wisconsin glaciation, as well as the probable starting ground. It seems not improbable, however, that a remnant of the ice sheet may have persisted far to the north on the west side cf Hudson Bay to about as late a time as it remained in Labrador. Further studies are necessary to clear up this question.

In a brief paper appearing recently Leighton ${ }^{29}$ has adranced the view that the Iowan drift was deposited in the first or earliest substage of the last glacial stage. He has also proposed a reclassification of the Iowan and Wisconsin drifts. The evidence cited by Ieighton for referring the Iowan to the last glacial stage is the moderate state of leaching of the loess deposit whose stratigraphic position is between the Iowan and Wisconsin drifts and which he terms the Peorian loess. He maintains that the deposition of this loess embraced practically the whole interval between the deposition of the Iowan drift and the early Wisconsin, and that this interval is apparently too brief to represent an interglacial stage. $\mathrm{He}$ assumes that the development of a pebbly concentrate

28 Tyrrell, J. B., Ontario Bur. Mines Rept., vol. 22, pp. 197-205, 1913 ; Cong. géol. internat., $12^{\mathrm{e}}$ sess., Comp. rend., p. 533, 1914.

${ }^{20}$ Leighton, M. M., The Peorian loess and the classiflcation of the glacial drifts of the Mississippi Valley: Jour. Geology, vol. 39, pp. 45-53, January-February, 1931. 
on the Iowan drift prior to the deposition of the Peorian loess was a hasty process requiring a negligible amount of time, an assumption that is open to serious question. It remains to be determined whether this process, combined with the deposition of the loess, may not have involved so much time as to constitute a stage of deglaciation.

Leighton suggests that the early Wisconsin ice sheet of the Labrador field was in a state of advance while the Iowan ice sheet of the Keewatin field was being melted away, but he does not explain how such a singular relation could exist. It is evident that the Iowan ice sheet must have been melted away in order to give the Labrador part of the ice sheet the free field for westward expansion that it had in the Wisconsin stage. As indicated below, there was a wide extension of ice westward from the Superior basin into central Minnesota in the middle Wisconsin substage, covering the axis of Iowan ice movement. In the opinion of the present writer the disappearance of the Iowan ice sheet must have occurred in a relatively warm period preceding the cold period that brought on the Wisconsin glaciation.

The great glacial lakes.-When the ice border shrank within the limits of the Great Lakes basins waters were ponded in front of it to a sufficient height to find escape across low places on the rims of the basins. There was thus a discharge southwestward from the Erie Basin past a summit at Fort Wayne, Ind., into the Wabash Valley and from the south end of the Lake Michigan Basin to the Illinois Valley; also southward from the Lake Superior Basin through the St. Croix Valley to the Mississippi. With the withdrawal of the ice from the basin drained by the Red River there came a ponding of water in that basin. As the ice melted back the ponded area enlarged until it finally reached an estimated area of 100,000 square miles, or about as great an area as the combined areas of the five lakes of the St. Lawrence system-Superior, Michigan, Huron, Erie, and Ontario. This great ancient water body, known as the glacial Lake Agassiz, is the subject of a monograph by Upham, ${ }^{30}$ published more than 30 years ago. The present writer has extended the study of the shore lines of this glacial lake considerably beyond the limits mapped by Upham in northern Minnesota, as will appear in the detailed discussion.

\section{PHYSICAL FEATURES AND ROCK FORMATIONS OF MINNESOTA}

The situation of Minnesota, in the east-central part of the North American continent, is such that it is drained entirely to the Atlantic side of the continent but by three widely divergent courses, part of the

\footnotetext{
${ }^{30}$ Upham, Warren, U. S. Geol. Survey Mon. 25, 1896.
}

drainage leading to the Gulf of Mexico, part to the Gulf of St. Lawrence, and part to Hudson Bay. The Gulf of Mexico receives about 57 per cent of the drainage, the St. Lawrence less than 9 per cent, and Hudson Bay fully 34 per cent. There was a time, however, in the latest part of the glacial epoch, after the ice had melted from Minnesota but was still occupying the northeastern part of the Lake Superior Basin and neighboring parts of Ontario and Manitoba, when all the drainage had a southward course to the Gulf of Mexico. The western part of the Lake Superior Basin for a time discharged through the St. Croix Valley to the Mississippi. The Red River Basin, when occupied by glacial Lake Agassiz, was drained southward through Lake Traverse and the Big Stone Lake to the Minnesota Valley and thence to the Missis. sippi and the Gulf of Mexico. This condition was maintained only until the ice had ceased to block the present lines of discharge, but the valleys excavated by the outlets of the glacial lakes in the Lake Superior Basin and the Red River Basin are very conspicuous features because of the great volume of the streams that excavated them.

Minnesota has an extreme length of nearly 400 miles, from the Iowa line, in latitude $43^{\circ} 30^{\prime}$, to the north end of the projection known as the northwest angle, northwest of Lake of the Woods, 23 miles north of the forty-ninth parallel. The greatest width is 367 miles, but the average width is about 225 miles. The State embraces an area of 84,682 square miles, of which about 93 per cent is land and 7 per cent water. There are fully 7,000 lakes within its borders. The largest is Red Lake, which has an area of 440 square miles. Other large lakes are Mille Lacs, Leech, Winnibigashish, and Minnetonka. It is estimated that about 14 per cent of the State is swamp land, part of which, by artificial drainage, can be rendered fit for cultivation. The swamps and lakes thus occupy about one-fifth the area of the State. The remaining fourfifths is fairly well drained, though there are many places in which tile drainage is of much value in disposing of the surface water and aerating the soil.

The altitude of Minnesota ranges from 2,230 feet, on a rock hill in western Cook County, in the northeastern part of the State, to 602 feet, the level of Lake Superior. The average altitude is about 1,200 feet, and a large part falls between 1,000 and 1,500 feet. (See fig. 2.) The portions above 1,500 feet are chiefly in two areas, one at the northeast corner of the State and the other at the southwest corner, though there is a fair-sized area around the sources of the Mississippi River, in the western part, and several small tracts in that same vicinity. The main portions below 1,000 feet fall in two areas, widely separated except for a narrow connecting strip along the Minnesota River-one in the Red River Basin, on the 
western edge of the State, and the other between the Mississippi and St. Croix Rivers, in the eastern part. There is also a narrow strip bordering Lake Superior.

The altitudes just given pertain to the drift surface and the surface of Lake Superior. The bedrock surface is buried in a large part of the State to a depth of more than 200 feet. The buried rock floor of the drift deposits removed from the State the average altitude would probably be reduced to 1,000 feet or less.

In a number of counties in the western part of the State borings have reached a depth of 300 feet or more without striking rock, and too few reach rock to give a basis for an accurate estimate of the thickness of the drift. The drift is also very thick in the high district in the southwestern part of the State, known as the Coteau des Prairies, there being several records of borings in that region in which rock had not been reached at a depth of 500 feet. The drift is very scanty in the southeastern part of the State, in Wabasha, Olmsted, Winona, Fillmore, and Houston Counties. Parts of Winona and Houston Counties li e within the driftless area of the upper Mississippi Valley. The upland here is 1,200 to 1,300 feet or more above sea level.

In Pipestone and Rock Counties, in the southwestern part of the State, there are quartzite ledges : with an altitude of 1,500 to 1,700 feet or more. The quartzite is also promi$\mathrm{nent}$ in Cottonwood County and western Watonwan County, at altitudes of 1,200 to 1,400 feet or more. These quartzite areas and the high area in southeastern Minnesota are the most prominent parts of the rock forma-

Figure 2.-Map of Minnesota showing altitudes above sea level
Mississippi Valley in the southeastern part of the State is about 500 feet above sea level and the bedrock surface at the southwest end of Lake Superior seems to be nearly down to sea level, for the drift deposits are 400 to 500 feet thick at that end of the lake, as shown by borings along the south side of the St. Louis River in the vicinity of Superior, Wis. ${ }^{31}$ Were the

a Wisconsin Geol. Survey Bull. 35, p, 13, 1912. tions in the southern half of the State, and they constitute less than 10 per cent of its area. The surrounding land has a rock surface at an average altitude of scarcely 1,000 feet.

The most rugged part of the State is in the northeast quarter. It is occupied largely by volcanic formations and iron-bearing rocks which, though glaciated, are but thinly covered by the glacial deposits. The 
most conspicuous relief in this district is found in the Sawtooth Range and other prominent ridges that closely border Lake Superior and rise to an altitude of 700 to 1,000 feet above the lake. The rock ranges lying back from the shore, though higher than those fronting on the lake, do not generally rise more than 200 to 300 feet above the swamps and lakes among them. In fact, several of the lakes in Cook County are more than 1,900 feet above the sea, or within 300 feet of the level of the highest points in the State.

A prominent rock range lying some distance back from the Lake Superior shore is the Mesabi iron range, which runs northeastward from the Mississippi River near Grand Rapids across the central part of St. Louis County. Its most prominent part stands 400 to 450 feet above the bordering plains and about 1,800 feet above sea level.

In the high northeastern part of Minnesota the valleys are very shallow and the streams descend in cascades to Lake Superior. In Cook and Lake Counties they descend 900 feet within a few miles. This area was probably not crossed by large drainage lines before the glacial epoch, and this may be one reason why the valleys are so shallow. This view seems sustained by the fact that a short distance northeast of the Canadian line the Kaministiquia River comes into Lake Superior through a large valley with a gentle rate of descent in its lower course.

The St. Louis River, which is now a tributary to Lake Superior, is flowing for most of its course through a lowland between the Mesabi iron range and ranges fronting on Lake Superior. Its course is southwestward toward the Mississippi River in western St. Louis County, and probably in preglacial time it was continued to the Mississippi. Its present deflection southeastward into Lake Superior may have been caused by an ice advance from the northwest that blocked its old course to the Mississippi. It has been suggested by Lawrence Martin that the St. Louis River was drained into the Lake Superior Basin in preglacial time as a result of stream piracy, ${ }^{32}$ it being his thought that a small stream working headward from the Lake Superior Basin cut a notch in the range of slate near Carlton and captured a large drainage system north of that range. However, he does not locate the notch in the range, and the present writer is unaware of any notch or gap in the vicinity of the place where the St. Louis River now crosses it. Martin's interpretation thus seems to be purely hypothetical and lacks supporting data. The present course was evidently begun late in the Wisconsin stage of glaciation.

The prominent Coteau des Prairies, in the southwestern part of Minnesota, was for some time interpreted by geologists as owing its great prominence

32 U. S. Geol. Survey Mon. 52, pp. 112-113, figs. 9, 10, 1911. chiefly to Cretaceous strata, which were thought to fill in the gaps between the high areas of Sioux quartzite noted above. But studies by Meinzer ${ }^{33}$ along the Coteau and later studies by the present writer have shown that the filling between the quartzite areas consists largely of glacial material, borings having been put down to depths of 400 to 500 feet without encountering rock. The quartzite areas thus seem to stand above the general level of the bordering Cretaceous formations, much as the Baraboo quartzite of southern Wisconsin stands above the surrounding Paleozoic formations. The highest altitude reached by the Cretaceous of southwestern Minnesota may not exceed 1,300 feet. The Coteau surface has an altitude of 1,700 to 1,900 feet or more along the highest part of its crest in Minnesota. The morainic ridges of Wisconsin age, which to some extent follow the crest of the Coteau, stand only about 50 feet above the district outside. It thus appears that the great bulk of the glacial material on the Coteau was laid down in earlier stages of glaciation.

The preglacial drainage of western Minnesota was probably northward along the lowest part of the Red River lowland in about the present drainage course. It is possible that part of the headwaters of the present Mississippi were tributary to the Red River lowland in preglacial time, but the available data are insufficient to throw much light on the question.

The southern part of Minnesota, now drained by the Minnesota, Des Moines, Mississippi, and St. Croix Rivers, appears to have had a preglacial southeastward drainage, in courses not widely different from those of the present streams. Borings indicate that a preglacial stream flowed southeastward from the basin of Lake Minnetonka across the Minnesota Valley, just above its mouth, and thence through Dakota County, a few miles south of the present Mississippi. This old valley and that of the present Mississippi may have united a few miles above Hastings. Another preglacial valley came southward through the eastern part of St. Paul and followed the present Mississippi to the valley just noted. A preglacial valley followed the course of the St. Croix River from Stillwater to the junction with the Mississippi. This convergence of streams and continuation of the combined stream down the Mississippi is thought to indicate that the preglacial drainage took the same direction and course as the present Mississippi. It appears to have followed essentially the present course as far as the vicinity of Clinton, Iowa, beyond which the course probably was southeastward to the Illinois Valley at the great bend near Hennepin, Ill. ${ }^{34}$ The bed of the valley that leads southeastward from Lake Min-

s Meinzer, O. E., U. S. Geol. Surrey Water-Supply Paper 256, pp. 233-235, pl. 2, 1911.

st Leverett, Frank, Outline of Pleistocene history of the Mississippi Valley: Jour. Geology, vol. 29, pp. 615-626, 1921. 
netonka is only about 500 feet above sea level in northwestern Dakota County, Minn., or nearly 200 feet below the level of the present Minnesota and Mississippi Rivers at their junction. The altitude of the rock floor at the border of the Mississippi at Fort Snelling is 486 feet. Borings along the Mississippi Valley in southeastern Minnesota and farther south show that the rock floor of the valley descends down the course of the old stream. It is less than 400 feet above sea level at Clinton, Iowa, about 340 feet near Hennepin, IIl., and 280 feet opposite St. Louis, Mo.

It is important to bear in mind that the excavation of the valleys to this low level appears to have been accomplished in preglacial time and not in interglacial or postglacial time. The records of wells along the Mississippi Valley in southeastern Iowa and exposure along its bluffs show the oldest or Nebraskan drift beneath the Kansan and Illinoian drifts. What is regarded by the writer as Nebraskan drift at Fort Madison extends down to a level 135 feet below the present stream at that point, or to about 365 feet above sea level. The writer wishes to emphasize this matter, inasmuch as Trowbridge ${ }^{35}$ has argued that the Mississippi River probably did not flow along the northeast border of Iowa prior to the Nebraskan ice invasion and that some streams were at that time flowing at a level about 600 feet higher than the rock floors of the present streams.

The preglacial drainage flowed from the vicinity of St. Paul and Minneapolis southeastward across a figher region than that in the vicinity of these cities. The bluffs of the Mississippi in the vicinity of Winona and southward about to the Iowa line are 500 to 600 feet above the present stream, or 1,100 to 1,200 feet above sea level; but in the vicinity of St. Paul the rock bluffs are about 300 feet lower, or only 800 to 900 feet above sea level. This peculiar condition is discussed by Hall and Meinzer ${ }^{36}$ as follows:

In going from St. Paul down the Mississippi this discordance between the direction of drainage and the direction of the upland slope is apparent. At St. Paul the cliffs from the valley bottom to the upland level are only of moderate height, but they become increasingly higher downstream, at a rate entirely out of proportion to the gradient of the stream, until they tower above the river in picturesque grandeur. Farther south, along the eastern margin of Iowa, the upland surface slopes southward, and the cliffs diminish in height. * * *

The uplands of southeastern Minnesota and adjacent parts seem to represent a surface which was first beveled and then gently bowed up. The Mississippi River flows through this elevated area in a direction nearly opposite to the direction of the inclination of the surface. Such a condition could be brought about in several ways, but probahly the river existed before the present elevation and was able to cut down its

35 Trowbridge, A. C., Iowa Acad. Sci. Proc., vol, 21, pp. 208-209, 1915 ; Iowa Univ. Studies, vol. 9, pp. 115-127, 1921.

${ }^{30} \mathrm{Hall}$, C. W., and Meinzer, O. E., U. S. Geol. Surrey Water-Supply Paper 256, pp. 31, 36, 28-29, 1911. valley rapidly enough to maintain its course in spite of the regional uplift. The amount of erosion effected by the Mississippi and its tributaries in this area gives a rough measure of the time that has elapsed since the uplift and the present denudation cycle began. * * *

The southenstern province, adjacent to the Mississippi and approximately 500 feet above it, is traversed by an intricate drainage system which has cut innumerable steep, rugged valleys and ravines several hundred feet into the hard rocks in some localities, learing only remnants of the plateau surface. * * * A thousand steep-graded ravines conduct rain water to the Mississippi. The erosion features are conspicuous, for the present cycle of denudation is well under way and has nearly reached the stage when the denuding processes shall have attained their maximum activity.

In general, the valleys of the streams that are flowing in the drift-covered portion of Minnesota are of small size and represent the work of the present drainage lines, but there are some large valleys which were excavated by streams flowing from the melting ice or from glacial lakes that fringed the ice border. The most conspicuous of these valleys is the one now utilized by the Minnesota River from Big Stone Lake to its mouth. This valley is about 200 feet in depth and half a mile to 4 miles in width. It was excavated by the outlet of glacial Lake Agassiz to which the name River Warren has been applied. ${ }^{37}$

The tributaries of the Minnesota come to the border of this valley in shallow trenches of their own excavation and then make steep descents into the great valley. The lower end of the Minnesota Valley is now being graded up by the silt brought in from the upper part of the valley. Lakes in the lower end of the valley (see topographic map of Minneapolis quadrangle) mark the unfilled places and carry 20 to 30 feet cf water at low stages of the river. From a position near the mouth of the Minnesota to St. Paul this outlet of Lake Agassiz cut a valley in rock formations a mile wide and 200 feet deep. It then entered a preglacial valley which comes to the present river from the north.

Another large valley is that of the St. Croix River, excavated by the outlet of glacial Lake Duluth. This valley ranges in width from a fraction of a mile where it cuts across rock ridges, as at Taylors Falls, to 5 or 6 miles where it is excavated in easily eroded glacial deposits. The lower end of the St. Croix Valley is now occupied by a lake, for the Mississippi River has built up sediment across the mouth of the St. Croix and raised the water level about 40 feet above the level at which the streams flowed at the end of the period of drainage from the glacial lakes.

Bordering the gorge of the Mississippi River above its junction with the Minnesota is a broad, shallow valley, formed by the water drained from the ice sheet. This is older than the great valley cut by the

3i Upham, Warren, Am. Assoc. Adv. Sci. Proc., vol. 32, p. 231, 1884. 
outlet of glacial Lake Agassiz and has its bed at the level of the top of the rock formations into which the Lake Agassiz outlet cut between Fort Snelling and St. Paul. The gorge of the Mississippi below Minneapolis was cut in the bed of this glacial river channel after River Warren, the Lake Agassiz outflow, had eroded its deep channel below the junction of the Minnesota and Mississippi Rivers.

\section{OUTLINE OF THE GEOGRAPHY AND GEOLOGY OF MINNESOTA ${ }^{38}$}

In its general geographic and geologic relations the Minnesota district forms a part of the Central Lowland, which lies between the Allegheny Plateaus on the southeast, the Ozark Plateaus on the southwest, and the Superior Upland on the north, and extends westward to merge into the Great Plains. It is situated near the northern margin of the Central Lowland, not far from the border of the southwestern extension of the Superior Upland that is called "The Ranges," otherwise known as the Lake Superior highlands. (See fig. 3.) The Minnesota district embraces the greater part of the upper Mississippi Basin and of The Ranges.

The upper Mississippi Basin subprovince includes a bout 10,000 square miles, mainly in Wisconsin, which escaped glaciation and is called the driftless area. In other respects, however, the history of the driftless area is similar to that of the surrounding region. The Ranges are covered with drift and in this respect are similar to the Central Lowland, though different in many other respects. The Ranges comprise a region of old crystalline rocks and of worn-down mountain ranges, whereas the Central Lowland is underlain by a series of nearly horizontal beds of sedimentary rocks. The upper Mississippi Basin subprovince is underlain chiefly by Ordovician and Cambrian rocks.

These sedimentary rock formations beneath the drift in the upper Mississippi Basin are thickest on the south and thin out toward the north. These rocks lie everywhere upon older crystalline igneous and metamorphic rocks of pre-Cambrian age. The older rocks come to the surface chiefly in the northern part of the subprovince, where the sedimentary rocks are absent. The structure of the crystalline rocks is com-

${ }^{38}$ Adapted from description by $\mathbf{F}$. W. Sardeson in U. S. Geol. Survey Geol. Atlas, Folio 201, 1916. plex, and their surface was deeply eroded and planed down before the sedimentary deposits were laid down upon them. The general distribution of the rock formations beneath the drift in the Minnesota district is shown in Figure 4.

The Cambrian system comprises sandstone and some dolomitic formations and has a maximum thickness of about 1,000 feet. The beds lie nearly horizontal and thin out toward the north, their margins overlapping the older crystalline rocks, which formed most of the land at the time they were deposited. At some places a thick series of red sandstone and shale of supposed Algonkian age lies beneath the Cambrian strata.

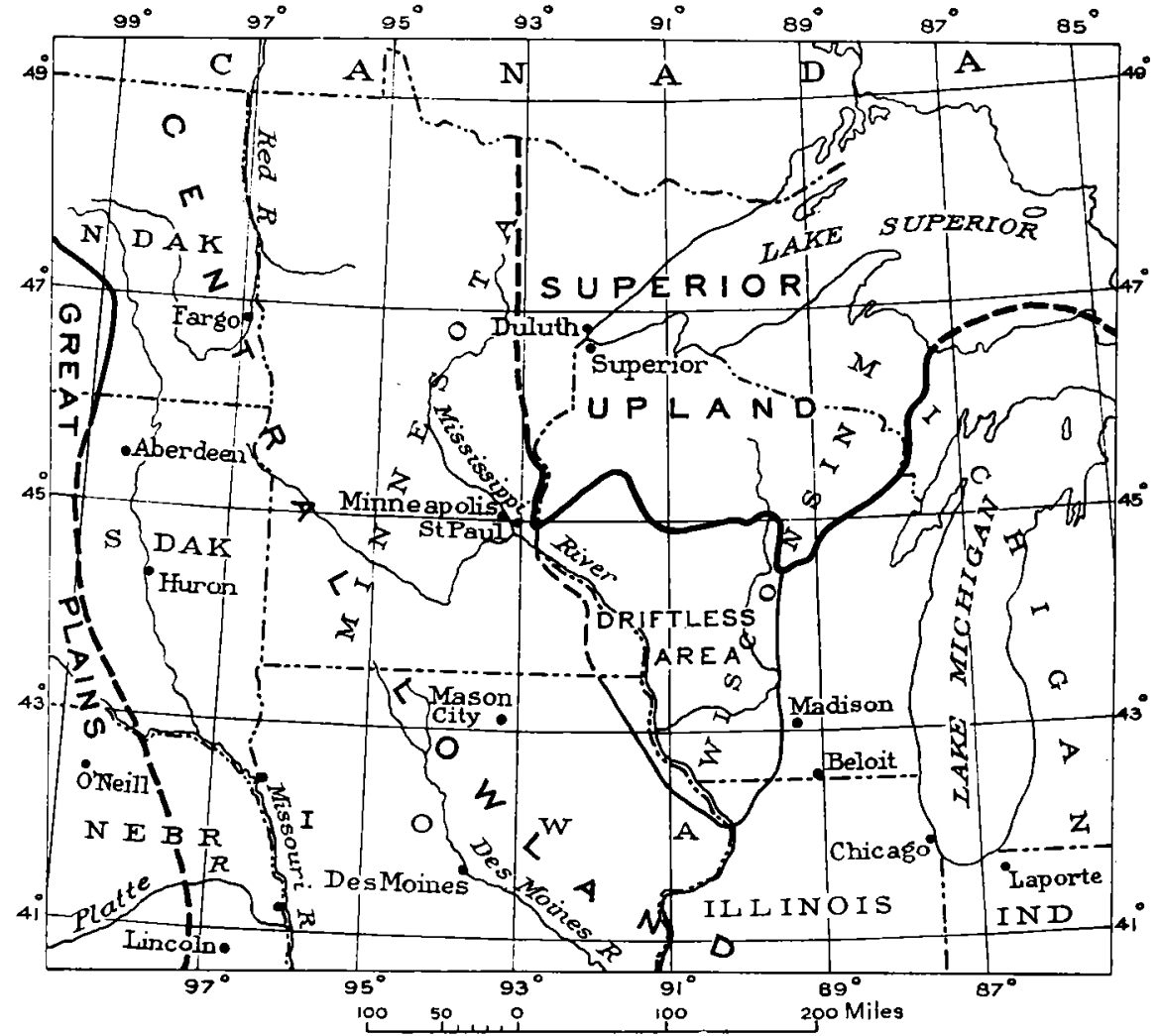

IGLEE 3.-Plysiographic provinces of Minnesota and adjacent regions

The Ordovician system consists of thin formations of limestone, dolomite, shale, and some sandstone. The deposits that formed these rocks were laid down upon the Cambrian rocks over all this subprovince but at the north have been removed by erosion, so that the Ordovician rocks do not extend as far north as the Cambrian. Each formation of the Ordovician system is less widespread than the next underlying cne, and the complete succession is found only in the neighborhood of overlying Silurian or Devonian limestones.

Representative formations of the Silurian system were laid down over only the outer border of this subprovince in eastern and southern Wisconsin, in Illinois, and in Iowa, but not in Minnesota. They are chiefly dolomitic limestones, which include many coral 
reefs. They were laid down in clear, shallow seas while this region was a low coastal plain between the Superior Upland on the north and the sea on the south.

The Devonian system covers the Silurian and extends beyond it, resting on the Ordovician, in south-
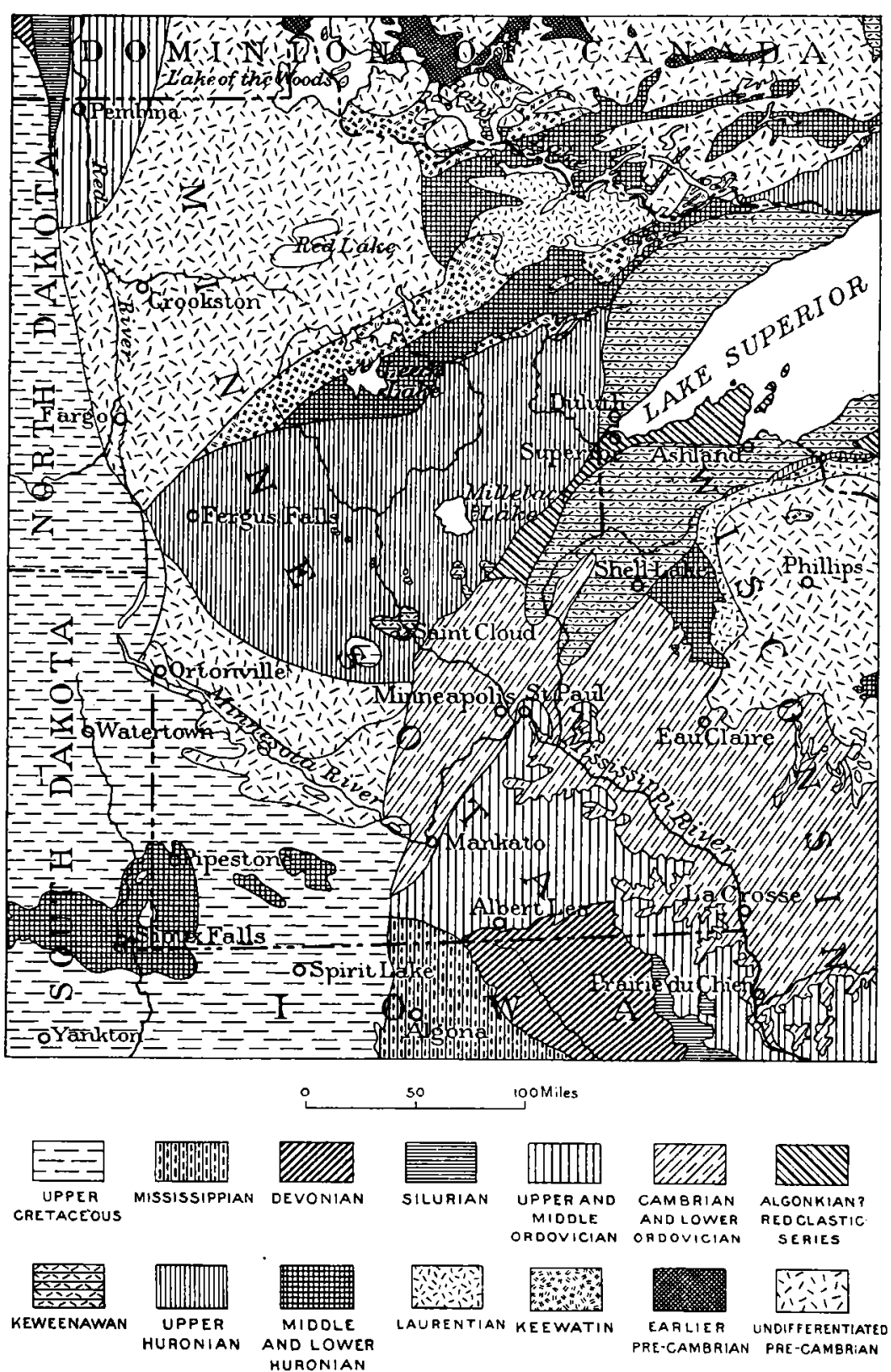

FigURE 4.- Geologic map of Minnesota and adjacent region, showing distribution of rock formations. In much of the area the bedrock is deeply covered with glacial drift. (From geologic map of North America in U. S. Geol. Survey Prof. Paper 71, 1912, somewhat revised)

ern Minnesota (fig. 4), but elsewhere it has been more eroded and is less extensive than the Silurian system. It consists of limestone and clay shale, which were laid down under nearly the same conditions as the Silurian deposits.

During the Carboniferous period, when the Pennsylvanian and Mississippian series were formed in the neighboring subprovinces on the south and east, this region was a lowland area subject to slight erosion. Essentially the same conditions prevailed later, during the Triassic and Jurassic periods, although the seas were then farther distant from this region.

Cretaceous fluviatile and estuarine beds, consisting generally of unconsolidated sand and clay, are found at some places in southern Minnesota. The more extensive marine formations of the same age in the Dakota subprovince on the west do not reach southwestern Minnesota. During Tertiary time the present Mississippi drainage system was established and the valleys were eroded deeper than they are now. No Tertiary deposits are known in this subprovince. So far as known the surface throughout Minnesota was land and was subjected to erosion in Tertiary time.

The Quaternary deposits are widespread. Glacial drift, including unconsolidated material, from melting ice, from rivers, and from lakes, covers the greater part of the surface and has in places a thickness of several hundred feet. Even within the driftless area nearly all the surface is covered with wind-blown loess.

\section{THE OLDEST DRIFT (NEBRASKAN) DISTRIBUTION AND CHARACTER}

As indicated in the outline of drift sheets (pp. 3-5), there are two very old drifts, representing the first and second stages of glaciation; in Minnesota and bordering States. The limits of the oldest, or Nebraskan, drift appear to be not greatly different from those of the second, or Kansan drift. In each of these glacial stages the ice sheet moved southward from central Canada over the same series of rock formations, so the drifts are similar in constitution and general characteristics. They are both deeply weathered and much indurated. The constituent pebbles are generally in an advanced stage of decay. Many of the granites are so highly disintegrated that they can be cut by a spade or trowel, and the feldspars are kaolinized to a perceptible degree. Limestone is a conspicuous element in each drift, forming usually 50 per cent or more of the pebbles, and many of the limestone pebbles are so much softened that they can be easily crushed to powder.

Over a wide region from the Missouri Valley northeastward across Iowa and Minnesota into Wisconsin, the oldest drift consists mainly of a nearly black till, 
in which a large amount of woody material, still present in identifiable species, was incorporated. It seems to contain the black alluvium and dark humus soil of the region over which the ice sheet passed. McGee applied the terms "bituminous" and "carbonaceous" to this till, as noted by him in northeastern Iowa. The black till extends into western Wisconsin along the west side of the Driftless Area and has been noted in the St. Croix Valley as far north as Grantsburg, Wis. Farther north and east it is very scanty, to judge by well records. Numerous lenses of orange-yellow sand and gravel are included in the till, as well as more extensive interbedded gravel formations. Such beds appear to be much more extensive in this drift than in the overlying Kansan, so that wells are frequently sunk through the Kansan drift to these gravel beds in a considerable part of Iowa and in parts of Minnesota and western Wisconsin to obtain water.

As the oxidized portion of each drift is yellowish brown, where only this portion is exposed it may be difficult to distinguish one drift from the other, and it is rarely that exposures extend into the unoxidized portion. Where the drift is less than 10 feet thick it consists entirely of oxidized material. The exposures in which the two drifts exhibit their distinguishing characteristics are thus relatively few. In the western part of Minnesota and Iowa, where Cretaceous shale is present, the pre-Kansan drift appears to be more abundantly supplied with this material than the Kansan. In a considerable part of its area the Kansan drift shows a tendency to crack vertically and form a "jointed clay." This feature seems to be rare in the underlying drift, which has a tendency to crumble rather than cake.

In southwestern Minnesota both drifts are present in great thickness. There is 50 to 100 feet of Kansan drift on the divides between the main drainage lines, and the underlying drift is in places 300 to 500 feet or more thick. The relief of the Coteau des Prairies is due in large part to the great thickness of these drifts along it. The same is true of the high part of western Iowa along and near the divide between the Mississippi and Missouri drainage systems, the thickness of these drifts there being from 200 to 500 feet or more. The Big Sioux and Missouri Rivers have cut deeply enough to expose both drifts, and there are a few exposures of the lower drift along some of the smaller streams of western Iowa. Carman ${ }^{39}$ has noted a number of such exposures along the Little Sioux River and Mill Creek in Cherokee County, Iowa. He states that the Nebraskan till is more compact and tougher than the Kansan and contains fewer pebbles and boulders. Limestone pebbles are also a less con-

${ }^{39}$ Carman, J. E., Iowa Geol. Survey, Twenty-sixth Ann. Rept., pl. 25. 1917 . spicuous constituent of the Nebraskan till than of the Kansan in that locality. This difference may be due to the greater incorporation of the underlying Cretaceous shale in the lower till.

The two old drifts seem to be present in considerable thickness beneath the Wisconsin drift in much of its area in Minnesota. The rugged northeastern part of the State, however, has rather scanty deposits of all the drifts. The older drifts are commonly classed by well drillers as "hardpan." Exposures of the old drifts within the area of the Wisconsin drift are few and of slight extent but are sufficient to bear out the testimony of the drillers that the deposits are much more inclurated than the Wisconsin drift. There is considerable blue-black till in the western part of the State. Toward the east it extends a short distance beyond the valley of the Mississippi River and is present in western Wisconsin from the vicinity of Grantsburg southward to the borders of Lake Pepin. Some of this blue-black till may prove to be of Kansan age, as it comes nearly up to the base of the Wisconsin drift, with only a few feet of oxidized Illinoian drift between the blue-black till and young drift.

East of the border of the Wisconsin drift in southeastern Minnesota and neighboring parts of Wisconsin and Iowa the drift deposits vary remarkably in thickness. Some of this variation is due to the deposits being thicker in preglacial valleys than on intervening uplands. Some thick strips, however, follow the course of the divides between drainage systems, where erosion is naturally less rapid than on the borders of the drainage lines. But there are wide areas where the variations do not seem to depend upon either of these relations. The drift is very scanty in some places for several miles back from the present drainage lines, and its thinness seems to have been determined by other factors preceding the erosion by the present drainage systems. These drainage systems probably date from no farther back than the withdrawal of the Kansan ice sheet, and possibly some of them from the Iowan, though as a rule the postIowan drainage seems to have followed essentially the same courses as the post-Kansan drainage. The scantiness of drift thus appears to have been an original condition so far as the Kansan and Iowan deposits are concerned. But it may not have been an original condition of the pre-Kansan. There are possibilities of removal by glacial erosion at the Kansan stage, as well as extensive stream work in the long Aftonian interglacial stage. There are also possibilities of glacial erosion at the Iowan stage. Where the deposits are preserved in considerable thickness they consist largely of the blue-black till with abundant woody matter, and the till contains a large percentage of 
Cretaceous material. There are also embedded in it many quartz pebbles from the pre-Pleistocene gravel beds of the region. The presence of so much local and semilocal material in the drift seems to favor its assignment to the earliest glaciation rather than the Kansan. The Kansan may prove to be a relatively thin deposit in this region, in the strips of thick drift as well as where the drift is thin.

At several places in southeastern Minnesota and neighboring parts of Wisconsin and Iowa there are soils and beds of peat and muck between till sheets, which have been commonly referred to the Aftonian interglacial stage. Among the earliest brought to notice are those of western Fillmore County and southern Mower County, Minn., discussed by Winchell. $^{40}$ As a rule the bed of muck and peat is found at the moderate depth of 20 to 30 feet. The greatest depth noted is 50 feet; the least is only 7 feet. Where the drift is thin the peaty beds are found near its base, but where it is thick they are near the top. It thus appears that the lower drift had been almost entirely removed in some places but was preserved in considerable thickness in others. Possibly the Iowan is also represented in the drift above the peat and muck, but it has not been clearly recognized.

As the data are derived entirely from well records they throw little or no light on the amount of alteration by leaching and weathering which the underlying drift had experienced. In some places the drift is said to be entirely of bluish color, a feature that may be áue to swampy conditions having prevented the oxidation of the till beneath the peaty muck. Records of this sort are liable to be faulty and should be judged in the light of evidence obtained where a similar succession of deposits is open to view.

A condition similar to that in Fillmore and Mower Counties is found in exposures in railroad cuts near Woodville, Wis. In a cut just west of the railroad station two tills are separated by a bed of peaty material, which contains considerable wood. The underlying till has a greenish color for a few feet below the peat bed, such as is characteristic of swampy areas. The pebbles in it are so decayed as to be easily pulverized. There thus seems to have been a deglaciation interval of considerable length before the overlying till was brought in. 'This interval seems to have been longer than is consistent with the recession and readvance in a single glacial stage. It is, however, not improbable that the development of interglacial features here noted required only a fraction of the entire Aftonian stage. The lower till may have first ex-

10 Winchell, N. H., Am. Assoc. Adv. Scl. Proc., vol. 24, pt. 2, pp. 43-56; 1876 ; Minnesota Geol. and Nat. Hist. Survey, vol. 1, pp. 313$315,363,1884$. perienced a period of erosion that developed a valley in whose bottom lands swampy conditions and the development of peat came in the later part of the Aftonian stage. In this exposure the peat bed is at a lower level than neighboring rock ledges and is thus near the edge of an old valley. Records of wells in Woodville show that the drift filling there extends to a level 80 to 100 feet below the peat bed. This drift fills a preglacial valley, but the peat may lie in an interglacial valley cut in the early part of the Aftonian stage.

These railroad cuts show two distinct tills above the peat bed. Immediately over the peat is a bluish till, which is oxidized and leached in its upper part and is apparently to be referred to the Kansan stage. It has a thickness of about 25 feet. Above this is a drift of strikingly different constitution, with numerous red rocks brought in from the district bordering the west end of Lake Superior and with a distinctly reddish tinge in the clayey matrix. This drift is described lelow as a probable Illinoian deposit.

Woodville stands in one of the areas of thick drift noted above, records of several wells within a few miles both north and south of the village showing 150 feet or more of drift. The deposits seem to fill an old valley, for there are outcropping ledges near by on either side. Only the upper 30 to 40 feet of this glacial material seems to be referable to the Kansan and later drift, thus leaving more than 100 feet for the oldest glacial stage.

Another exposure of a peaty bed between tills is found in a cut on the Chicago, Rock Island \& Pacific Railroad 2 miles southeast of Faribault, Minn. Here black soil and greenish-gray subsoil are exposed near the level of the railroad track. Above the soil is about 20 feet of bluish till, with pockets of very rusty gravel, stained deeply with iron. Above this the till is oxidized to a yellowish-brown color and is leached to a depth of about 4 feet. This drift, which seems more likely to be of Kansan age than Illinoian, is overlain by 12 to 15 feet of fresh-looking drift of Wisconsin age.

The glacial deposits below the mucky soil are relatively thin, for rock is exposed along the Straight River a few rods south of the cut, at a level scarcely 20 feet lower. The pale ashy-green color of the subsoil indicates swampy conditions, as well as the mucky soil. Here too, as in the exposures at Woodville, a period of erosion may have preceded the development of the mucky soil.

Two analyses of the mucky soil in this railroad cut by Frank F. Grout, of the University of Minnesota, are of especial interest in showing that the muck really contains but a small amount of organic matter. 
Analyses of Aftonian (or Yarmouth?) soil near Faribault, Minn.

[Frank F. Grout, analyst]

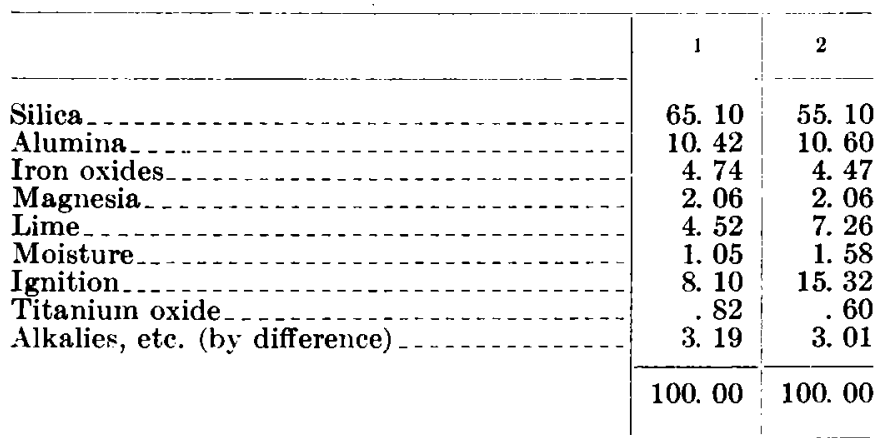

Excellent exposures of at least three sheets of drift are to be seen along the southern tributaries of the Minnesota River between Mankato and New Ulm. There are also exposures here of a preglacial quartz gravel resting on the Paleozoic formations. The lowest till, presumably of the first glacial stage, has considerable very rusty, orange-colored gravel associated with it. The till in places has a greenish-gray cast, like a swamp subsoil, but without associated peat beds. In other places it is deeply iron stained and of dark-brown color. The Kansan till of this district is much indurated and shows a tendency to form joints and break in cubical nearly rectangular blocks. Neither of these old drifts averages more than 30 feet in thickness in this locality. But where preglacial valleys have been filled the thickness of the lowest till may exceed 100 feet. The Wisconsin drift here is 30 to 50 feet thick.

The gummy soil and subsoil between tills at Flandreau, S. Dak., is only 1 to 3 feet thick and is blackened by humus. The underlying till is of brown color and exposed to a depth of 20 feet. It shows but little leaching, though its pebbles are rotten and easily pulverized. It is probably pre-Kansan, for the till above the soil is Kansan. The upper till has suffered considerable erosion and only its basal part is here present.

It was supposed by Winchell, and his opinion is generally accepted, that the patches of old drift and the scattered pebbles and boulders found along the west side of the Driftless Area in Minnesota and Iowa represent the frayed-out edge of the oldest drift, and that the limits of the second or Kansan drift are farther west, where a heavier deposit sets in. This interpretation, however, has some elements of uncer. tainty. It is not clearly established that this is the scanty remnant of a thick sheet of drift. The deposit may have been thin originally.

In the southwestern part of Minnesota, in Pipestone and Rock Counties, the quartzite ledges carry two sets of glacial striae-an earlier set bearing nearly south and a later set bearing south-southwest. It seems not unlikely, though not clearly evident, that the earlier set is the product of the first glaciation and the later set of the second. These ledges are now nearly bare over wide areas, yet there is little doubt that they have been covered by the two ice sheets. It is surprising that such faint features as striae should be so well preserved from the remote time even of the later of these glacial stages. There may, however, have been a covering of till during the greater part of the time since glaciation occurred. In fact, the present bareness of the ledges may be a condition of relatively recent origin.

Along the St. Croix River from Taylors Falls, Minn., southward past Osceola, Wis., there are exposures of drift that embrace Kansan and probably pre-Kansan drift as well as later drifts. In the northwestern part of Taylors Falls the west bluff of the river exposes the following beds, where a road ascends the bluff.

\footnotetext{
Section of bluff exposure at Taylors Falls, Minn.

iT: i Seet

1. Yellow calcareous till (Wisconsin) in patches

2. Gravel of red drift material (Wisconsin) _....... 5-15

3. Indurated brownish-yellow calcareous till, becoming gray near base in thickest part (probably Kansan) _ 8-20

4. Gravel and cobbles of red-drift material, filling an old valley (probably pre-Kansan) _-____-_-_-_ 50-70

5. Red till, gummy and of bright color near top, but paler and more flaky and jointed below (probably pre-Kansan)

6. Red assorted material in alternate coarse and fine
} beds exposed along the road. $10-25$

When followed westward Nos. 5 and 6 thin out and end at the base of a sandstone bluff. The indurated till, No. 3, exhibits the usual characteristics of Kansan drift, with infiltration of dark material in seams or joints. The included limestone pebbles are well rounded and of a type common in southern Manitoba. The patches of yellow till at the top of the bluff seem referable to the Grantsburg sublobe of the Keewatin ice in late Wisconsin time; the red drift underneath seems to be assignable to the Patrician ice of the Wisconsin stage.

In a ravine a few miles south of Taylors Falls, in sec. 15, Franconia Township, Chisago County, Minn., there is at the top a deposit of fresh gray till of the Grantsburg sublobe, 10 to 15 feet thick. Below this is a deposit of red-drift gravel estimated to be 80 feet thick. This appears fresh enough to be of Wisconsin age. Beneath it is a red till of bright color at the top but of a duller shade below, which is about 35 feet thick and extends to the rock. This till, like that at Taylors Falls, appears to be pre-Kansan, though it may prove to be as late as Illinoian. In it are 
places where limestone fragments form about $25 \mathrm{per}$ cent of the stony material, but generally limestone is scarce. There seems to be none of the indurated calcareous till here of Kansan type, but in the southern part of the adjacent sec. 16 of this township a deep ravine exposes an indurated calcareous till of Kansan type, which has been referred to that stage by $R$. T. Chamberlin. ${ }^{41}$ It is of brownish-yellow color at the top, with ferruginous seams and tubes. 'This grades downward into a dark-blue till, which is clayey and calcareous but not very stony. The red till was not found in this ravine. There are other places between Taylors Falls and Osceola where an old till rests on the rock ledges, but the exposures are only of slight depth.

\section{EFFECT ON OUTLYING DRAINAGE}

The first Pleistocene glaciation seems to have covered the Mississippi Valley as far down as Winona, Minn., and also the lower course of the Chippewa River. The St. Croix drainage area was entirely covered at this glacial stage. The outlying drainage on the east embraced the tributaries of the Mississippi that have courses wholly or in part through the Driftless Area, such as the Buffalo, Trempealeau, and Black Rivers and the lower part of the Wisconsin River. The Mississippi Valley from Winona, Minn., to Savanna, Ill., and probably to Clinton, Iowa, was encroached upon only slightly by the earliest ice sheet. The preglacial course of the Mississippi may have been southeastward from Clinton through the Green River Basin to the Illinois at the great bend near Hennepin, Ill., and thence down the present Illinois Valley to the junction with the present Mississippi River. This course, also, may have been outside the earliest ice sheet. If so, the Mississippi maintained its preglacial course from a point near the mouth of the St. Croix down to the mouth of the present Illinois, as well as below there to the Gulf of Mexico.

Although the old Mississippi Valley may not have been occupied to any great extent by the first ice sheet below Winona, Minn., it is probable that the valley was filled to some degree by the glacial drainage of that stage. The gradient of the river at that time, which depends on the amount, if any, of differential uplift, is a matter on which we have very little knowledge. If the district it traverses had the same altitude relations as at present, the gradient was low, for the rock floor is 100 feet or more below the level of the present stream, and the fall from the mouth of the St. Croix to the Gulf of Mexico is scarcely 500 feet. This low gradient might suffice for a clear stream such as the preglacial Mississippi probably was, but it would have been very low for a turbid stream, such as the

4 Jour. Geology. vol. 18, pp. 542-543, 1910. river is likely to have been during this stage of glaciation. There may, therefore, have been considerable aggradation in the vicinity of the border of the first ice sheet as far down as its southern limits, near St. Louis, Mo., or nearly to the Gulf of Mexico, as indicated below. Very few data have yet been obtained to throw light on the upper limit of filling in this valley during the first or the second glacial stage, nor are we able to distinguish clearly between fillings of each stage. Gravelly deposits are preserved on a rock shelf on the north side of the Wisconsin River near its mouth, at a level about 200 feet above the river. These are evidently glacial, for they contain numerous striated pebbles, and large quartzite boulders are found on and in the gravel. These deposits have been tentatively referred to the Kansan stage by MacClintock, ${ }^{42}$ who has made a special study of the lower course of the Wisconsin River. But they lie somewhat outside the generally recognized limits of the Kansan and may prove to be of pre-Kansan age. A deposit of river rubble containing erratics of glacial derivation was noted by the writer near the northeast limits of the city of Dubuque, Iowa, on the east side of the Couler Valley, whose upper surface reaches a level 150 to 160 feet above the present Mississippi flood plain, or about 760 feet above sea level. It seems probable that the Mississippi Valley was at one time filled to this height, but whether at the first or at the second glacial stage has not been determined. The Kansan ice probably extended about to the Mississippi Valley in the vicinity of this deposit. Filling to the height reached by these deposits at the mouth of the Wisconsin River and at Dubuque may have been general along the Mississippi Valley during each of these glacial stages. The great amount of erosion since these early stages and between them naturally has left only a few scanty traces of the valley filling.

The Wisconsin Valley carries remnants of an old filling which was made by a stream flowing westward into the Mississippi and which is best preserved in the vicinity of Muscoda and the Blue River, where it stands fully 75 feet above the present flood plain. These remnants have been studied by MacClintock, ${ }^{43}$ who interprets them to be older than Illinoian. The deposit is so old that the limestone and dolomite pebbles which it probably once contained have been completely dissolved. In some respects it appears older than the deposit near the mouth of the Wisconsin, above noted. The border of the old drift, of which this terrace remnant is the valley train, is now concealed beneath the Wisconsin drift of the Green Bay lobe. These terrace remnants are of importance in

2 MacClintock, Paul, Jour. Geology, rol. 30, p. 680, 1922.

${ }^{43}$ Idem p. 677 . 
showing that glaciation at a stage earlier than Illinoian affected the region east of the Driftless Area, as well as that to the west. Farther south, in Illinois and Indiana, and also in southeastern Missouri, are found evidences of a pre-Illinoian drift..4 This old drift seems to have been brought in from the Labrador center of glaciation.

The Chippewa and its western tributaries were probably covered by the earliest ice sheet, and the deeper part of the filling in their valleys is probably in large part of the first glacial stage, for it is unlikely that the interglacial stream cutting extended to the low level reached by the preglacial streams. The smaller streams to the east of the Chippewa, such as the Buffalo, Trempealeau, and Black Rivers, were less completely covered by the earliest ice sheet, though scattered boulders are found along the Buffalo and bordering hills clear to its mouth, and the headwaters of the Trempealeau and Black Rivers may have been covered at this first glacial stage. The writer has not made a detailed study of these valleys, but in a trip up the Trempealeau Valley he noted in the vicinity of Arcadia deposits of very old gravel which seem referable either to the Illinoian or an earlier glacial stage. They are exposed beneath a fresher gravel which is probably a filling of Wisconsin age, connected with the aggradation of the Mississippi. As preserved, this old gravel reaches a height of only about 30 feet above the present stream, but it stands as a witness to aggradation in one of the earlier glacial stages.

The effect of the earliest Pleistocene glaciation on the drainage lines that led toward the ice sheet from the west was revolutionary in their lower courses. The upper Missouri and its tributaries as far down as the White River in South Dakota appear to have had preglacial drainage to Hudson Bay instead of to the Gulf of Mexico. ${ }^{45}$ The shifting to a southward course through the Dakotas probably took place in the first or Nebraskan glacial stage. But whether it returned to the old course in the succeeding interglacial stage and then was again deflected in the Kansan stage is not known.

There appears to have been a ponding of the streams of Nebraska, Kansas, and western Missouri at the earliest glacial stage, as no continuous, well-defined channel of the deflected Missouri outside the drift border in these States has been noted. The Platte River was the main stream discharging to the Gulf of Mexico. It has recently been suggested by Greene ${ }^{46}$ and supported by considerable evidence that the pre-

4 Leverett, Frank, U. S. Geol. Survey Mon. 38, pp. 107-111, 1899

45 Todd, J. E., Science, new ser., vol. 39, pp. 265-267, 1914. Bauer, C. M., Jour. Geology, vol. 23, pp. 52-58, 1915. Alden, W. C., Geol. Soc. America Bull., vol. 35, pp. 412-414, 1924.

${ }^{48}$ Greene, F. C., Preliminary sketch of the history of the lower Mis. souri: Geol. Soc. America Bull., vol. 32, pp. 83-86, 1921. glacial Platte River flowed southeastward across northwestern Missouri and came to the present Missouri Valley near the mouth of Grand River. The preglacial Kansas River appears to have followed the course of the present Missouri from Kansas City to the mouth of Grand River, where it met the preglacial Platte River, and the combined stream followed the course of the present Missouri to its mouth, near St. Louis.

If the earliest ice invasion extended into the district west of the Blue River, as seems probable, the ponded waters may have found a southward outlet to the Arkansas River through a valley that leads across the present divide through Saline and McPherson Counties, to which Udden ${ }^{47}$ called attention some years ago. The valley is about 150 feet deep and several miles in width, and its deeper part is filled with gravel and sand. Udden writes:

The Smoky Hill River (a tributary of the Kansas) has carved its bed through the northern end, and here erosion has nearly reached the old bottom, and the river has thrown its mantle of alluvium over extensive areas along its course. The southern end, extending from the valley of the Smoky Hill to that of the Little Arkansas, is marked by a rather steep slope along the western margin and by a chain of lakes and basins that make a rather unique feature in a country that is otherwise well drained.

The gravel is reported by Udden to include pebbles of different kinds of crystalline rocks, fragments of silicified wood, and bones of Megalonyx and the horse, as well as several kinds of mollusks. These beds become clayey near the top, and on the surface of the clay is a bed of volcanic ash. This in turn is covered by "yellow marl," apparently loess. On the borders of the valley, at an altitude of 1,480 feet, the ash bed rests on "a thin black seam containing bog manganese and bog iron, and underneath the jointed clay is dark and carbonaceous." If this was a line of southward discharge for waters ponded in front of the ice at the earliest stage of glaciation, it makes an easy solution of the question of the ice-border drainage. Study is now in progress by the Kansas Geological Survey to test this interpretation.

The ice covered the lower course of the preglacial Kansas River as far up as the mouth of the Blue River, near Manhattan, Kans., in the second stage of glaciation. It extended to an undetermined distance south of the valley in eastern Kansas and western Missouri. This may have been at the earliest glacial stage, as there is a less continuous drift than the Kansan usually presents, and the boulders are much decayed. Granite boulders are found as far up the Osage Valley as Tuscumbia, Mo., and are present elsewhere south of the Missouri River at all altitudes up to the

${ }^{47}$ Udden, J. A., Megalonyx beds in Kansis: An. Geologist, vol. 7 . pp. 340-345, 1891 
highest places on the divides. The ice appears to have covered several of the smaller southern tributaries of the Missouri sufficiently to prevent their finding outlet through that valley. They, as well as the headwaters of the Osage River, may have been ponded sufficiently to find outlets eastward through low passes to the south of the Missouri Valley. The course of such drainage remains to be determined. The effect of the pre-Illinoian encroachment of the Labrador ice sheet on the Mississippi Valley below St. Louis is also undetermined.

The extent to which the lower Mississippi Valley may have been filled by glacial drainage at the first glacial stage is briefly discussed by Chamberlin and Salisbury ${ }^{48}$, as follows:

At Natchez, Miss., there is a section of assorted material about 200 feet in thickness, which is chiefly made up of derivatives from the Lafayette formation, upon which it rests unconformably, but it also contains crystalline pebbles and calcareous clays assignable to wash from the glacial regions, all other assignments seeming to be excluded by a special investigation. A marked interval between its deposition and that of the overlying loess is indicated. As the sub-Aftonian and Aftonian deposits are the only older ones with which great gravel deposits are known to be associated, and as the Natchez deposit must be referred to an early Pleistocene stage, because the great Mississippi trench, 60 miles more or less in breadth, has been excavated since it was formed, reference to one of these two stages is more plausible than to any later one. This reference is strengthened by the fact that almost the whole formation, which was clearly a valley train leading back to the drift area, has been removed.

Assuming the correctness of this reference and combining it with other data, the following tentative conception of the sub-Aftonian and Aftonian stages is reached. The ice sheet spread from the Keewatin and Labradorean centers to the approximate limit of the known drift in the Mississippi Valley and deposited a typical sheet of boulder clay (sub-Aftonian) and also gave rise to great valley trains of glaciofluvial material that stretched from the drift border to the Gulf.

The credit of noting pebbles of greenstone, porphyry, etc., among the shingle of the lower Mississippi Valley should be given to Hilgard, ${ }^{49}$ but he supposed that the pebbles might have come from formations in Arkansas and thus have had no relation to the Pleistocene glaciation. 'This interpretation seems to have been set aside by the special investigation by Chamberlin and Salisbury referred to in the above quotation.

\section{KANSAN DRIFT}

\section{DISTRIBUTION AND CHARACTER}

In the second or Kansan stage of glaciation an ice advance from central Canada passed across Manitoba, Minnesota, and Iowa into Missouri, with a slight encroachment on the western edge of Wisconsin and Illi.

\footnotetext{
s Chamberlin, T. C., and Salisbury, R. D., Geology, vol. 3, pp. 386$388,1906$.

${ }^{9}$ Hilgard, E. W., Am. Jour. Sci., vol. 41, p. 318, 1866.
}

nois and a broader encroachment on North and South Dakota, Nebraska, and Kansas. This stage of glaciation has become widely known as Kansan, the farthest limits of its drift being found in the State of Kansas. Its western limits in the Dakotas are undetermined. They may be no farther west than the Missouri Coteau.

There seems also to have been an ice advance from the district of Patricia southward through the basins of the upper Great Lakes and across the Erie Basin into the bordering States. This advance is tentatively referred to the Kansan stage. Copper nuggets and copper-bearing rocks of the Lake Superior region were carried into Indiana and Ohio by this ice move. ment, and a single copper nugget has been found at Warren, Pa. The drift of this eastern district lies almost entirely outside the region treated in the present report. In the northeastern part of Minnesota, north of Lake Superior, about on the border between the Keewatin and Patrician ice movements, there seems to be very little Kansan drift. There are, however, heavy deposits of what seems to be Kansan till a short distance farther northeast, in the lowlands bordering the Kaministiquia River, in the Province of Ontario. It is an indurated jointed till, similar to the Kansan of Iowa and adjacent States and strikingly in contrast with the overlying fresh Wisconsin till.

The Kansan drift of the western district is a calcareous blue-gray till, containing rocks derived from the limestone formations of southern Manitoba, together with Cretaceous shale from Minnesota, as well as a liberal supply of crystalline rocks from Canada and Minnesota. This old calcareous till has been found on the Mesabi iron range as far east as the mine pits at Hibbing, where it is extensively exposed beneath a very stony drift of Wisconsin age. It probably underlies the Wisconsin drift in the basin south of this range drained by the St. Louis River. The red clay of the western part of the Lake Superior Basin scems to be largely pre-Wisconsin, and a considerable part of it may be referable to the Kansan glaciation. It includes limestone pebbles, but the source of the pebbles has not been determined.

In the district south of the limits of the Wisconsin drift in western Wisconsin the Kansan drift is present as far east as the border of St. Croix and Dunn Counties and the eastern part of Pierce County. In Wisconsin and Minnesota it extends about to the east end of Lake Pepin. A line marking the east edge of a definite sheet of till runs southward through eastern Wabasha, western Winona, and central Fillmore Counties, Minn., into Iowa. Both the pre-Kansan and the Kansan drift seem to extend about as far east as this line, for the buried soils noted in the discussion of the pre-Kansan drift are present within a few miles to 
the west. The till above the old soil is referred to the Kansan glaciation. As already indicated, the patches of drift east of the line are of uncletermined age.

Throughout its extent in Minnesota and neighboring States the Kansan drift shows considerable induration in the unoxidized as well as the oxidized portions. 'The well drillers liken it to frozen ground. It is very difficult to excavate with a spade, a pick being usually required to loosen it. The overlying Wisconsin drift, on the other hand, is easily spaded.

The depth of oxidation of the Kansan drift is far from uniform and seems to depend on the facility with which water penetrates the deposit. Where the till is traversed by deep vertical cracks or joints, as in southern Iowa and northern Missouri, oxidation generally extends to a depth of 35 to 40 feet. In Minnesota the till shows a more moderate depth of oxidation. In places the bluish till is within 10 or 15 feet of the surface. The gravel deposits are more deeply affected, both by oxidation and by leaching, than the till. In a gravel pit about 6 miles westsouthwest of Adams, in southern Mower County, the limestone pebbles have been leached out for the entire depth of the pit, 22 feet. Chert pebbles such as are derived from cherty limestone formations occur throughout the gravel, so there probably were at least a small number of limestone pebbles in the original deposit. This gravel was probably laid down as an outwash deposit on the border of the ice sheet, for it stands at the general level of the upland. Its beds show a southward dip, directly away from a drainage line north of the pit. This pit was examined by the writer in company with George F. Kay in 1925, and the degree of leaching here displayed was considered by each entirely consistent with the alteration required in the production of the Kansan gumbotil.

The development and preservation of the Kansan gumbotil seem to have been much greater in southern Iowa and northern Missouri than farther north. The material reaches a depth of 5 feet at few places in northeastern Iowa, but is 6 to 8 feet or more deep in southern Iowa. It is best preserved there and in northeastern Missouri in the Mississippi drainage basin, as erosion there has not reached so advanced a stage as that on the Missouri River side of the divide. The difference in the amount of erosion of the Kansan drift in this part of the Mississippi and Missouri drainage basins appears to be to a large degree a result of the advantages for rapid opening of deep drainage lines tributary to the Missouri. The Mississippi tributaries from southern Iowa southward into Missouri have in many places in their lower courses been compelled to cut into resistant rock formations, whereas the Missouri tributaries have not encountered such formidable barriers, excavating mainly in glacial deposits. In northeastern Iowa the drainage has been less retarded by rock barriers. The exceptional retardation to drainage probably has been an important factor in the development as well as in the preservation of the gumbotil. The gumbotil is a conspicuous feature from the Missouri-Mississippi divide in southern Iowa eastward to the Mississippi River but lessens perceptibly in amount westward toward the Missouri River. Its area of exceptional development thus nearly coincides with the part of the Kansan drift area in which drainage development was retarded by the rock barriers. Another important factor may be found in the difference in degree of humidity. It is in the more humid parts of Iowa and Missouri that the gumbotil is best developed. The cover of vegetation in these more humid areas may have been better suited to check erosion and to hold such atmospheric material as settled on it than the vegetation in less humid areas.

The Kansan drift appears to have been a relatively thick deposit over western Minnesota, averaging perhaps more than 50 feet. This thickness appears to have been maintained southward across western Iowa and adjacent parts of Nebraska, Kansas, and Missouri. In Iowa it appears to maintain a considerable thickness as far east as the Iowa River. But the part east of the Iowa River, like that in southeastern Minnesota, seems to lack evidence of an original general thickness of Kansan drift comparable to that found in the districts to the west. Instead, as indicated in the discussion of the underlying drift, there are strips of considerable width in which it seems to have been originally thin. Evidence of the development of a drift plain such as is so well shown in southern Iowa is lacking. Consequently, it is difficult to determine the amount of post-Kansan erosion in this part of Minnesota and Iowa. Estimates are further complicated by a later (Iowan) glaciation in this region.

\section{EFFECT ON OUTLYING DRAINAGE}

The ice in the Kansan stage may have covered the Mississippi as far down as the lower end of Lake Pepin but probably did not obstruct the Chippewa and other eastern tributaries farther south. It covered the headwaters of some of the western tributaries of the Mississippi from the Zumbro River southward, both in Minnesota and Iowa, as far as Clinton, Iowa. If the Mississippi was then maintaining a course southeastward from Clinton to the Illinois Valley, through the lowlands noted above (p. 18), the Kansan ice invasion probably caused no change in its course. There thus appear to have been no important drainage shiftings of the Mississippi or its tributaries on the east side of the Kansan ice sheet. 
On the west side of the ice sheet the Missouri River may have been free to follow its present course about as far as Yankton, S. Dak., but was covered below that place. There was probably some ponding of waters on its border from the vicinity of Yankton southward to the Platte Valley, as well as southward from the Platte. The valley of the Blue River was covered so deeply at the culminating position of the ice border that it could not give a line of discharge to the Kansas River. There was a slight displacement of the Kansas River near Topeka, Kans., and a ponding of water, called by Todd Kaw Lake, in the valley above that city. The ponded waters discharged into the valley of Wakarusa Creek, ${ }^{50}$ but this affected the stream only as far as Lawrence, Kans. The border of the Kansan drift appears to lie north of the Kansas River and north of the Missouri as far east as Carrollton, Mo. Below Carrollton, in Saline and Cooper Counties, drift that.seems referable to the Kansan stage is found on the south side of the river. Todd ${ }^{51}$ called attention to old drainage courses across these counties just outside the Kansan drift limit that probably carried the drainage for a brief period. From Cooper County down to the mouth of the Missouri the Kansan ice sheet seems not to have reached the valley.

The reports of the Iowa Geological Survey contain frequent references to what is termed Buchanan gravel, from exposures noted by Calvin ${ }^{62}$ in $\mathrm{Bu}$ chanan County, Iowa. Although originally called an interglacial deposit, the descriptions given generally relate to gravel that seems to have been closely connected with the Kansan glaciation. In some places it may have been laid down as outwash from the ice sheet, but in quite as many other places the gravel cleposits were involved in the till. The term has also been applied to gravel laid down as a secondary deposit along valleys that were excavated in the Kansan till. In general the Kansan drift is remarkably free from deposits that are to be interpreted as outwash, throughout its wide exposure in Kansas, Nebraska, Missouri, and Minnesota: The drainage from its border appears to have been generally sluggish during the recession of the border from central Missouri northward across Iowa into Minnesota. One of the few places where deposits that seem to be outwash have been noted is that in southern Mower County Minn., in which the gravel pit above described (p. 21) was opened.

${ }^{50}$ Todd, J. E., History of Wakarusa Creek : Kansas Acad. Sci. Trans., vol. 23, pp. 211-218, 1911.

51 Todd, J. E., Formation of the Quaternary deposits in Missouri : Missouri Geol. Surrey, vol. 10, pp. 134-142, 1896.

${ }^{62}$ Calvin, Samuel, The Buchanan gravels; an interglaclal deposit in Buchanan County, Iowa : Am. Geologist, vol. 17, pp. 76-78, 1896; Iown Acad. Sci. Proc., vol. 3, pp. 58-60, 1896.

\section{ILLINOIAN OR OLD RED DRIFT}

In Dakota and Washington Counties, Minn., and St. Croix, Dunn, Barron, and Pierce Counties, Wis., there is a sheet of reddish drift lying outside the limits of the Wisconsin drift and covering the earlier drifts. It lies like a blanket on the eroded surface of the underlying drift, covering the valley bottoms and slopes as well as the uplands. The amount of material is so slight that the streams are flowing in essentially the same courses that they had opened in the earlier drift prior to the deposition of the red drift. The average thickness of this old red drift is scarcely 10 feet, but in Dakota County, Minn., it is heaped up into a moraine, or prominent range of hills, that runs from Hampton southeastward nearly to the Cannon River. The hills are 75 to 100 feet high and form an intricate network a mile or more in width. They are composed largely of gravelly material but also contain boulder clay.

As the degree of weathering which this drift has experienced is much greater than is found on neighboring portions of the red Wisconsin drift, it has been classed by the writer as old red drift, the latter being called the young red drift. The contrast in the degree of weathering is especially striking in the gravelly parts of these drifts. The gravel of the old red drift is stained dark reddish brown to a depth of sereral feet. In this deeply stained portion only a few cherts remain to bear witness to the former presence of limestone pebbles. Limestone, however, may never have been so abundant as in the underlying Kansan drift.

This drift appears to have been brought in by a southward ice movement from the district bordering the west end of Lake Superior, and the rocks contained in it are very largely from nonfossiliferous pre-Cambrian formations. The red color is probably due to the large percentage of material from the red rock formations around the head of Lake Superior. The percentage of this material decreases southward, being markedly less in Pierce County, Wis., than in St. Croix and Barron Counties.

It is thought by Weidman ${ }^{53}$ that a lobe of ice, farther east than that just discussed, extended to the north edge of the Driftless Area from Dunn County eastward across Eau Claire, Clark, Wood, and Portage Counties, Wis. Studies by the present writer in 1923 on this drift support Weidman's interpretation. The Marshfield moraine of that district shows a degree of erosion and its pebbles a degree of alteration similar to those displayed by the moraines of Illinoian age in

an Weidman, Samuel, Wisconsin Geol, and Nat. Hist. Survey Bull 16, pl. 2, 1907 ; Geol. Soc. America Bull., vol. 24, pp. 697-698, 1913. 
Illinois. Outside that moraine there is a narrow strip of thin drift whose age is less clearly determinable, but in the absence of evidence to the contrary it is tentatively included in the Illinoian.

\section{IOWAN DRIFT}

\section{DISTRIBUTION AND CHARACTER}

Certain features in southeastern Minnesota are a continuation of those in Iowa which have been referred by the Iowa geologists and by Alden and lacking. The headwaters of most of the druinage lines are in broad, shallow swales, which fade out into nearly flat upland interstream areas. The valleys deepen and become very capacious in their lower courses, the size being similar to that of valleys cut in the Kansan drift of southern Iowa. Where they are developed in belts of thick drift, as in parts of Mower, Dodge, Goodhue, and Rice Counties, the depth of these valleys reaches 100 to 150 feet, and the bredth 1 to 2 miles or more. Here, as in northeastern Iowa, the impression is gained that a dendritic system of drain-

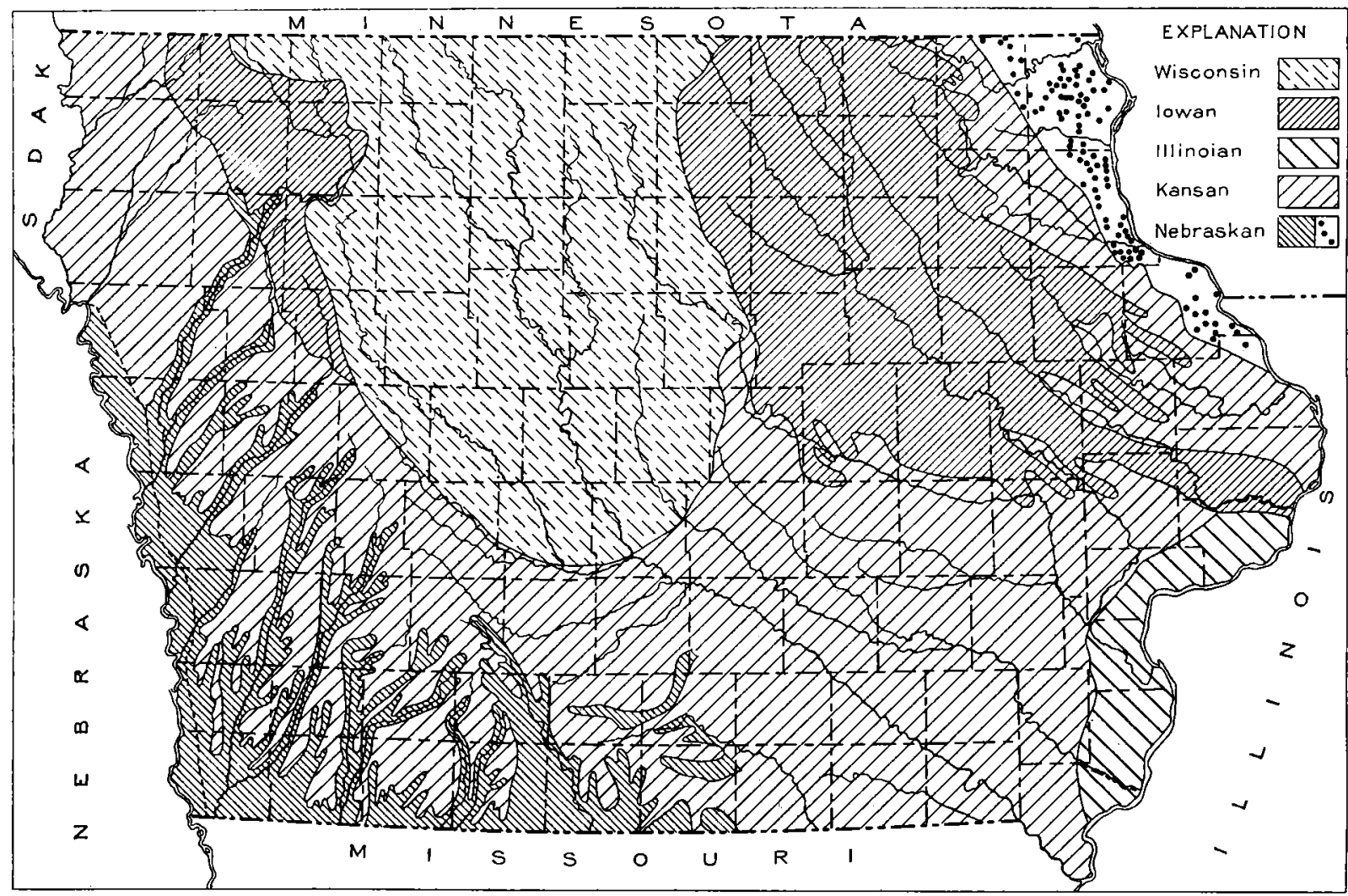

Figure 5.-Sketch map of Iowa showing surface distribution of the five sheets of glacial drift. (Redrawn from map by G. F. Kay and E. T. Apfel)

Leighton $^{54}$ to the Iowan drift. (See fig. 5.) They are about as clearly defined in Minnesota as in Iowa and are tentatively referred to the same drift. The features seem inconsistent with continuous and normal erosion of Kansan drift, such as that drift has experienced farther south, and are suggestive of a later ice invasion.

The dominant and most widespread feature of the Iowan drift is a peculiar topography which Alden and Leighton have called "mantled mature erosion topography." The main features of mature dendritic drainage systems are present, but minor branches are

st Alden, W. C., and Lelghton, M. M., The Iowan drift; a review of the evidences of the Iowan stage of glaciation: Iowa Geol. Survey Ann. Rept. for 1915. pp. 50-212, 1917. age had developed to maturity by ordinary stream erosion, and this had become partly masked, as if overridden by an ice sheet, which left the main valleys and major branches only partly filled. This mantled erosion topography is dominant in Mower and Dodge Counties, in the western part of Fillmore, Olmsted, and Goodhue Counties, and in eastern Rice County. Farther east the drift is relatively thin and the valleys are to a large extent preglacial.

The character of the surficial portion of the drift in this district where the mantled erosion topography is dominant seems to the writer to indicate decidedly greater age than that of the Wisconsin drift of the adjacent district on the west. This is most strikingly shown in a pebbly concentrate which was developed 
by slope wash and by wind action after the ice had deposited it. The presence of this pebbly concentrate was noted by Alden and Leighton,,$^{55}$ and it was interpreted by them to have been "left from the slight wind erosion and rain wash *** before the till was protected by the loess" and was thought to have been developed in a relatively brief time. It seems to the present writer to represent a removal of several feet of till, to judge from the small number of coarse pebbles and boulders embedded in the till directly under it. The concentrate is present on slopes facing in all directions. It is also more conspicuous on the lower part of the slope than over the crest. 'This fact may be of significance in working out the problem of relative effectiveness of the wind work and the slope wash in this district. 'The wind would seem likely to have greatest effect on the crowns of ridges in exposed situations. Slope wash is not restricted to slopes facing in a particular direction, and it has application in humid regions such as this. Many of the pebbles in this concentrate show the effect of sand blasting by the wind and thus support the view that wind took part in its development. Whether this sand blasting is more pronounced on slopes facing in a particular di. rection remains to be determined. The proper evaluation of this feature may be of service in determining the degree to which the wind has been a factor in producing the concentrate. The general prevalence of this pebble concentrate has been made more evident since the recent road-building period, when a large number of fresh cuts brought it to light. There are now many exposures where prior to the road building there were not half a dozen. A thin coating of loamy material, 1 to 4 feet in depth, is widely prevalent in the Iowan drift district as a cover to the pebble concentrate, and this has prevented its proper recognition. This loamy cover seems to be allied to the loess, which is found to some extent within the Iowan drift area as well as outside. It is a wind deposit, but whether of the same age as the main loess deposit or more recent is not known. As it is too thin to withstand complete leaching, it can not exhibit the calcareousness or the fossil content displayed by unleached loess. In the determination of the age of the Iowan drift the date of deposition of this cover, as well as the time involved in the development of the pebble concentrate, will have an important bearing.

The Iowan till is found by Alden and Leighton to have been leached of its lime content to a moderate depth below the pebble concentrate. A table presented by them ${ }^{56}$ shows that of 59 cuts examined 36 , or 63 per cent, showed leaching of 3 to $4 \frac{1}{2}$ feet, and of 165 auger borings, 92 , or 56 per cent, showed the same

${ }^{5 s}$ Alden, W. C., and Leighton, M. M., op. cit., p. 156.

so Idem, p. 82. amount of leaching below the surface of the till. In 11 cuts and 38 borings the depth of leaching was less than 3 feet; in 12 cuts and 18 borings it exceeded 5 feet; and in 1 cut and 4 borings it exceeded 7 feet.

The present writer's tests of depth of leaching of the lowan drift in southeastern Minnesota are in close accord with the results obtained by Alden and Leighton in Iowa. In southeastern Iowa, south of the Iowan drift limits, tests by the writer, as well as by Alden and Leighton, have shown the depth of leaching to be rarely less than 6 feet and not uncommonly to reach 15 feet or more. Tests of leaching of Kansan drift in western Wisconsin, where the old red or Illinoian drift overlies the Kansan, show a general leaching of about 6 feet, and this apparently took place prior to the deposition of the Illinoian drift. The material in the valley bottoms in the Iowan drift area, both in northeastern Iowa and in southeastern Minnesota, may be largely pre-Iowan, for it shows deeper leaching than the till of the uplands and slopes. In many places no lime was found in it at depths of 8 or $^{\circ}$ 10 feet, and it has a rusty reddish-brown color like Kansan material. The leaching seems to be greater in valleys inside the Iowan limits than in those outside that lead away from the drift border. The latter are more nearly in harmony with the leaching displayed by the Iowan till and by gravelly knolls within the Iowan area and may prove to be Iowan outwash. Belts of gravelly drift of strongly ridged and knolly type which have been developed along some of the valleys in the Iowan area have been leached of their limestone pebbles in some places to a depth of only 1 to 2 feet, and the gravel shows remarkable freshness in comparison with some of the gravel found in the adjacent valley bottoms. It thus appears not unlikely that the deeply weathered material of the valley bottoms is a pre-Iowan deposit brought in by the wash of the Kansan drift.

The preservation of kames and other knolls and ridges of constructional type within the Iowan drift area is a feature inconsistent with Kansan age, for in the Kansan drift areas outside the Iowan drift limits. the amount of erosion has been so great that the preservation of such forms is scarcely to be expected. In one of the southern counties of Iowa the erosion has. been estimated to average about 50 feet for the entire county. So far as the writer is a ware no knolls of constructional type have been noted on the Kansan drift in Iowa or any of the bordering States. Not only are knolls preserved within the Iowan drift area, however, but steep valley slopes are still coated with drift in the rugged eastern part of the area, where an amount of erosion such as seems to have taken place in postKansan time should have left but scanty remnants of the deposit. 
In southern Dakota County and northern Rice and Goodhue Counties, Minn., east of the Wisconsin drift border, there are rock prominences of mesa type, some of them rising abruptly to a height of 100 feet or more above the bordering plains, which usually carry a few feet of drift that seems of fresher aspect than the Kansan drift. The depth of leaching is only 4 to 5 feet, and the deposit is less indurated than is characteristic of Kansan drift and seems more probably of Iowan age.

In Fillmore County, Minn., the topography characteristic of the Iowan extends to the eastern edge of the heavy deposits of drift, in both the southwestern and northwestern parts of the county. Farther east the features are indecisive. There is a strip free from loess and containing very little drift, north and west of Granger, in Bristol Township and eastern York Township, over which the Iowan ice may have passed, but decisive evidence of such an extension beyond the border of the thick drift was not found. In western Fillmore County the drift is thin for several miles north, south, and east of Spring Valley. Large granite boulders of relatively fresh aspect are not rare in any part of this area and are numerous in some places. Possibly they were brought in by the Iowan ice sheet. In the northwestern part of the county there is a plain of thick drift, east of which is a strip of knolly drift that may be a marginal feature of the Iowan glaciation, though the gravel is deeply weathered. This knolly drift covers much of sections $20,21,28$, 29, 30, 31, 32, and 33, Jordan Township (T. 104 N., R. 12 W.). The presence of these drift knolls has disarranged the old drainage courses to some extent and caused the streams to cut new courses partly in the rock. The details of the drainage changes were not worked out.

In several places in Olmsted County there are features suggestive of Iowan glaciation, but they do not seem to form a definite marginal belt. For 2 or 3 miles east of Stewartville, in the southern part of the county, the drift has a knolly surface of constructional type and is liberally strewn with boulders, thus presenting features characteristic of an ice border. North of this locality, in the northern part of High Forest Township and eastward over Pleasant Grove Township (T. $105 \mathrm{~N}$., R. $13 \mathrm{~W}$.) there is very little drift but a general coating of loess. North of this loess strip there is a belt of thin drift nearly free from loess, 6 to 8 miles wide, extending from Rochester eastward past Eyota to Dover and continuing in a narrower strip into western Winona County. Features suggestive of Iowan glaciation are found near Dover. Shallow swales thickly strewn with boulders are char. acteristic features for 3 miles south of the village, clear up to the border of the loess-covered district.
These features are also found to the southwest, across the divide between the Whitewater and Root River drainage basins. Farther west, in the vicinity of Marion, several exposures of relatively fresh yellow calcareous till appear beneath the loess, just within the loess-covered district.

North of Dover, in a loess-covered district, gravel knolls are present, but they are as a rule nearly free from loess. In these knolls there are limestone pebbles within a very short distance of the surface, and the gravel is not deeply stained nor rusty looking. A gravel pit 25 feet deep in a knoll about 8 miles northnorthwest of Dover, 2 miles south of the Wabasha County line, has coarse cobbles and boulders with the gravel in the upper 10 feet, and limestone blocks are present clear to the surface, as well as many waterworn limestone pebbles. The deeper part of the pit is in a fine gravel of relatively fresh aspect. East from this pit for 2 miles, along the borders of secs. 7, 8, 17 , and 18, T. 108 N., R. 11 W., the drift has an undulating surface of glacial type and consists largely of gravel. It has subterranean drainage, which perhaps accounts in some measure for the preservation of the glacial topography. A similar topography, however, extends southward to section 28 and thence eastward into sections 23 and 26 in a district with good surface drainage. The knolls are bouldery and cobbly on the surface, features which add to the glacial expression. There is a rather abrupt change near the east side of Olmsted County to a nearly driftless condition, and the few erratics there present show more pronounced weathering than those in the knolly drift just noted.

West from this knolly strip clear to the valley of the South Fork of the Zumbro River, there is a loesscovered district with thin drift and very little to suggest Iowan glaciation, but in the northwestern part of Olmsted County, from Byron northeastward past Douglas to Orinoco, gravelly knolls are numerous. Some in southern Orinoco Township (T. 108 N., R. $14 \mathrm{~W}$.) are 50 to 75 feet in height. In several pits examined the beds dip northeastward, as if the knolls had been built up at the border of an ice lobe fronting in that direction. The gravel shows only a moderate degree of leaching, limestone pebbles being usually found within 4 feet of the surface. In some places the surface portion is iron stained and filled in with iron deposits. On the whole, the aspect of the gravel is scarcely as fresh as in the smaller knolls in the northeastern part of the county, above noted. The difference, however, may be due to unlike drainage conditions rather than to disparity in age. This gravelly district is in part free from loess but is nearly surrounded by loess-covered drift. Boulders are very numerous in low areas among the gravel knolls and to 
some extent are strewn over their surface. They seem to be more numerous than in the neighboring loess-covered districts.

In Wabasha County there are a few gravelly knolls near Elgin, in the same general district as those of northeastern Olmsted County, above noted, and within the drainage area of the Whitewater River. But in the Zumbro drainage basin there seem to be few features suggestive of Iowan glaciation below the mouth of the South Fork. Above that point, on both sides of the main Zumbro, in western Wabasha County, and in Goodhue County, such features are more pronounced. Some of the small tributaries have drift barriers that have deflected the streams into the bordering valley slopes, where they are now cutting trenches in the rock. Most of these barriers are knolly dumps that obstruct the old valleys for only a short distance. They preserve the glacial contours more perfectly than seems consistent with Kansan age. Northeast of Mazeppa the swales are choked with knolls of gravelly and stony drift, and no wide open valleys of erosion type occur. In places the bottom lands widen out to a quarter of a mile or more, but within a short distance upstream or downstream they narrow and look clogged with drift knolls. Almost complete clogging is shown in a valley at the west side of sec. 29 , T. 110 N., R. 14 W., where the stream has cut a narrow, deep trench through a gravelly accumulation. The upper part is cobbly and bouldery and poorly assorted. The deeper part is well assorted and shows a sharp southeastward dip. About 2 miles farther west, in the edge of Goodhue County, a drift accumulation in a valley near the line of secs. 24 and $25, T .110 \mathrm{~N}$, R. $15 \mathrm{~W}$., has turned a stream across a rock point on the north. On the west side of the Mazeppa and Lake City road in the southern part of sec. 7, T. 110 N., R. $13 \mathrm{~W}$., a low drift ridge lying in the midst of a valley has been trenched by a small drainage line leading westward across it. In this part of Wabasha County drift deposits are preserved on steep slopes to a degree that seems inconsistent with an age as great as that of the Kansan. This evidence is perhaps less definite than that of the drift knolls but is of value in support of it.

In northwestern Wabasha County there is an exceptionally prominent strip of knolly drift that has the general aspect of a terminal moraine. It is about 8 miles long and nearly 2 miles wide and passes entirely across the northwest township of the county from its northwest corner to the south line of sec. 34 . It dies out within a mile both at the north and at the south. It has a generally undulating surface above which a few sharp gravelly knolls rise to heights of 25 to 50 feet or more. The upland on which it lies is more than 1,100 feet above sea level, and the highest points reach 1,160 to 1,175 feet. It is thus about 500 feet above the level of Lake Pepin, which is only 4 or 5 miles distant to the northeast. The gravel shows a very moderate amount of leaching, limestone pebbles being abundant within 2 or 3 feet of the surface. It also shows but little discoloration by iron and is usually of a fresh gray color. The till is yellowish brown, of fresher appearance than the ordinary oxidized Kansan till. If this is an Iowan moraine, the limits of the ice in the district to the south would naturally be as far east as the district just noted, where knolls are obstructing the valleys.

In Goodhue County there is a strip of relatively thick drift on the high ridge south and southeast of Red Wing, in Hay Creek Township (T. 112 N., R. 14 W.), and this is continued across Wells Creek southeastward to the morainelike belt in northwestern Wabasha County just described. The features are not distinctly morainic, but there are several rather prominent gravelly knolls, and in some of them 60 feet or more of drift is penetrated in wells. The gravel knolls contain a large amount of local limestone, and in one in sec. 5 Sardeson found nodules of Cretaceous material of local derivation with willow-leaf imprints. The presence of so much local material impressed Sardeson as an indication that the drift should be referred to the earliest glaciation rather than to the Iowan, for it seems doubtful if there was much local rock exposed to contribute material for the later drift. $\mathrm{He}$ is therefore inclined to refer the thick drift and the knolly surface to peculiar preservation in the course of erosion of a very old drift. Of similar import seems to be the fact that both north and south from this ridge the drift is very scanty over a space several miles in width. The best exposures are in the gravelly knolls, where pits have been opened for road material, and this gravel shows only a moderate degree of weathering and leaching. Limestone pebbles are usually found within 2 or 3 feet of the surface. The degree of freshness seems to the writer suggestive of Iowan age.

About 4 miles west of Red Wing, in the northern part of sec. 3, Featherstone Township, gravel pits have been opened in a deposit in a recess or depression between rock hills. This deposit is directly south of an old drainage line filled with sand of Wisconsin age, but it stands about 50 feet above the level of the Wisconsin filling, or 800 feet above sea level. The drift is distinctly knolly, and its surface part contains numerous erratic boulders as well as large blocks of local limestone. The small limestone pebbles are dissolved out to a depth of 2 or 3 feet, and the deposit is weather stained to a depth of several feet. The moderate depth of leaching and the preservation of 
the knolly surface seem more consistent with Iowan age than with Kansan.

The deposits in Wabasha and Goodhue Counties contain relatively little red rock material such as characterizes the old red drift of the counties directly north-Pierce County, Wis., and Dakota County, Minn. The constitution of the drift indicates that the ice movement was from the west rather than from the north. The present writer was unable to find any clear evidence that the Iowan drift overlaps the old red (Illinoian) drift; instead they appear to be rather close correlatives.

In some parts of Goodhue County features suggestive of Iowan glaciation are stronger than in the marginal part just discussed. Thus along the south side of the Zumbro Valley, for several miles above Zumbrota, there is a belt of gravelly knolls, 1 to 2 miles in width, in which the material is only moderately leached and weathered. In all the gravel pits examined limestone pebbles were found in abundance within a foot or two of the top, and the gravel has an appearance nearly as fresh as in the Wisconsin drift. Boulders are very numerous, both on the knolls and on the low areas among them. The knolls are on the slope of a large valley that seems to have been excavated in the old drifts prior to the deposition of the gravel and boulders. The highest knolls are 60 to 75 feet above the swales among them, but their tops are scarcely as high as the bordering upland on the south. In neighboring districts there seems to have been at best only a thin coating of Iowan drift on the older deposits. A pit in the northern part of Kenyon shows 4 feet of very stony drift with numerous boulders over a deposit of gravel of medium coarseness. The appearance is that of an overridden outwash, in which only the upper 4 feet is of direct glacial deposition. It is doubtful if there is an average coating of Iowan material 4 feet thick in this county aside from the gravelly knolls. Such knolls are scattered over the central part of the county in the vicinity of Goodhue and for several miles in all directions from the village. Some of them contain nodules and lumps of clay from the local Cretaceous deposits, a feature that has led Sardeson to refer the deposits to the earliest glaciation, like those near Red Wing, cited above. The moderate degree of weathering exhibited by the deposits, however, does not seem to support such an interpretation.

If the Iowan ice extended into Goodhue County it must have crossed into that county from Rice and Dakota Counties. The greater part of Dakota County, outside the limits of the Wisconsin drift, is covered by the old red (Illinoian) drift or by gravel deposits connected with the Wisconsin glaciation. A few square miles in the southern part of the county lies $67665-32-3$ outside both of these drifts. It is mainly a district of thin drift with mesas rising 100 feet or more above intervening lowlands. Whether this thin drift is a remnant of Kansan or Nebraskan drift or is due in some measure to an Iowan ice invasion has not been clearly determined. South of the Cannon River between Northfield and Randolph there are a few gravelly knolls that may be Iowan, for they show only a moderate degree of weathering. A few such knolls are present north of the Cannon River in Castle Rock Township and southwestern Hampton Township, but the drift generally is without distinct constructional glacial features.

The pre-Wisconsin drift of eastern Rice County is characterized by small gravelly knolls in the northeastern part, where the drift is relatively thin, but in the southeastern part there are thick deposits of till in which large valleys have been carved, as in neighboring parts of Goodhue and Dodge Counties. In this area of thick drift there is very little that seems referable to Iowan glaciation. The valleys are broad and deep and of erosional type, about as in the Kansan drift outside the Iowan limits, yet they appear to be well within the limits of the Iowan drift.

In the greater part of southeastern Minnesota the boulders as a rule consist mainly of granite and syenite, with but a small percentage of basic rocks. In a few places in Goodhue County, however, R. T. Chamberlin found the basic Keweenawan rocks well represented. Thus in a railroad cut 2 miles northwest of Zumbrota he noted several boulders of Keweenawan diabase, porphyritic and amygdaloidal diabase, and the peculiar pitted "smallpox" diabase such as he had seen at Taylors Falls. In a cut 2 miles east of Bombay there is a gravelly drift with a large inclusion of red Keweenawan rocks resting on the clayey Kansan till. These puzzling sporadic occurrences are within the area that seems referable to Iowan glaciation.

There are many small gravelly hills in the large valleys in Mower and Dodge Counties that show a remarkable degreee of leaching of the limestone. In some pits 6 to 8 feet in depth no limestone pebbles were found, and the gravel has a very rusty aspect. This condition is thus strikingly in contrast with that shown in the gravelly knolls found on uplands farther north and east, nearer the border of the supposed Iowan drift. Possibly these are degradational features, the gravel being an inclusion in old drift, brought to light by the opening of the valleys. Such gravel is a common feature in the part of Dodge County south of Kasson and in the southwestern part of Mower County. Old gravel of this sort is found in some places on uplands, as near the southwest limits of Rochester and in Mower County southwest of Adams. It seems probable that limestone was once 
present in the gravel, for fossiliferous chert abounds in the deposit from the surface down in each of the pits examined. Such great leaching certainly seems more consistent with Kansan than with Iowan age.

From the foregoing description it may be seen that the features suggestive of Iowan glaciation or of postKansan glaciation in southeastern Minnesota affect only a small part of the surface of the district in which they occur. The peculiar type of valley classed as "mantled mature erosion" is restricted to the area in which the drift is of exceptional thickness. There the type of erosion and size of valleys are in places very similar to those developed on the Kansan drift of southern Iowa. The drift barriers in valleys are found in the eastern or peripheral part of the district that appears to carry Iowan drift, where the older drift is relatively thin. The chief development or preservation of drift knolls is also in this peripheral portion.

The degree of leaching and weathering in the gravelly knolls ranges from a deep and thorough removal of limestone in some of the knolls to a very moderate removal in others, and the rusty stain of the gravel shows a corresponding range. Where the leaching is deep and thorough the deposits appear to date back as far as the Kansan glaciation, and where it is modcrate the alteration seems consistent with Illinoian or Iowan age. In other words, the wide difference in leaching and weathering these knolls display seems best explained on the basis of a difference in age. In general the till shows several feet of surface leaching, but in a few loess-covered places there is scarcely any leached till. The cause for this exceptional condition has not been satisfactorily determined. Possibly it is due to infiltration of calcareous waters from the overlying loess, which probably carried calcareous material when first deposited. The till is oxidized but not so rusty or weather stained at the top as in districts where there is no loess cover, or as most of the loess-covered till outside this district. It is more common to find in the Iowan drift area a pebbly concentrate than a deeply weathered till at the base of the loess. Such a concentrate seems to the writer to indicate a considerable erosion interval between the deposition of the till and that of the loess. Leaching has, as a rule, been more rapid than the surface wash or erosion that developed the pebbly concentrate. It is the writer's observation that in the swales the depth of leached material is much greater than on the slopes, a large amount of leached material having been washed or otherwise carried into them. This contrast is shown markedly in northeastern Iowa, in the midst of the extensive loess-free Iowan drift area, but is also exhibited in the loess-covered peripheral portion.
The drift classed as Iowan differs in constitution from the old red (Illinoian) drift of the adjacent district to the northeast about as the young gray drift of Wisconsin age differs from the young red drift which it borders and overlaps, and it is but natural to infer that the Iowan and the old red (Illinoian) drift are referable to the same glacial stage. The degree of leaching can not well be compared, because the old red drift never had much calcareous material, whereas the Iowan probably had a considerable percentage of such material, except in places where it was derived from the leached surface of the older drifts. The old red drift is also looser textured and thus more liable to become deeply stained than the Iowan, which is generally clayey and compact. Taking these matters into consideration the writer is unable to present any conclusive evidence that the old red or Illinoian drift is older than the Iowan. The loesscovered portion of the old red drift shows a strong weathered zone that contrasts more strikingly with the overlying loess than the surface of loess-covered Iowan drift commonly does with its cover. But it is not improbable that this weathered appearance would be reached in as short a time as would be required for the development of the pebbly concentrate on the Iowan drift. It is also to be noted that the clayey Iowan may have suffered more reduction by wash than the loose-textured old red drift and may thus have developed a pebbly concentrate while the old red drift was developing a weathered zone.

The Iowan drift is so scanty and its limits in northeastern Iowa as well as in southeastern Minnesota are so ill defined that its extent is still an open question. There seems also to be an entire absence of recessional moraines. These conditions strongly suggest a stagnation or nearly complete cessation of movement in the Iowan ice sheet soon after it had reached its culminating position. The belts of gravelly ridges, which generally have a trend toward the border of the drift instead of parallel with it, are consistent with and seem to support the interpretation of a stagnation of ice movement.

As described by Alden and Leighton, ${ }^{, 7}$ the Iowan drift nowhere overlaps the Illinoian, for these authors favor the exclusion of the long lobate area in Clinton County, Iowa, that has been mapped by other writers as the Iowan, as well as several smaller tongues to the north. They are inclined to think that the Iowan ice sheet had a fairly regular border that extended about to the base of these lobate tracts. In the present writer's opinion these lobate tracts in northeastern Iowa have about as definite Iowan characteristics as the main area of Iowan drift, and they probably will

57 See Iowa Geol. Survey, vol. 26, pp. 171-181, and fig. 11, p. 122, 1915 ; also fig. 3 on back of topographic map of Camp Dodge area. 
have to be reckoned with before the Iowan drift question is satisfactorily settled. It may be found that the loess-covered strips between these long tongues of loess-free drift in northeastern Iowa carry a drift that should be included with the Iowan. The features of southeastern Minnesota that seem to indicate Iowan glaciation, as outlined above, fall largely in the loess-covered district and extend beyond the ends of the loess-free strips.

In conclusion, the writer is of the opinion that the occurrence of an Iowan stage of glaciation distinct from the Illinoian stage is not clearly demonstrated.

PROBABLE IOWAN DRIFT WEST OF DES MOINES LOBE OF WISCONSIN DRIFT

A strip of drift that borders the west edge of the Wisconsin drift of the Des Moines lobe in southwestern Minnesota and adjacent parts of Iowa and South Dakota (figs. 6 and 7 ) differs strikingly from the Kansan drift in topography and in degree of weathering and erosion, but it is somewhat more eroded and weathered than the Wisconsin drift of the Des Moines lobe. In the map that accompanies Bulletin 14 of the Minnesota Geological Survey, by Leverett and Sardeson, published in 1919, this drift was included in the Wisconsin area, as it seemed much nearer the Wisconsin than the Kansan in age, and some doubt was felt as to its being enough older to be referable to the Illinoian glacial stage and as to there being an Iowan glacial stage distinct from the Illinoian. In a later map, ${ }^{58}$ however, the present writer labeled this "Iowan? drift," the question mark being used to denote uncertainty as to the use of the term "Iowan" for the drift. From the foregoing discussion of the Iowan of northeastern Iowa and southeastern Minnesota it will be seen that the writer still feels doubt of an Iowan stage distinct from the Illinoian. He regards this post-Kansan drift in northwestern Iowa as a probable correlative of the drift that has been classed as Iowan. The particular label the drift receives is a matter of less consequence than the recognition of the presence of a post-Kansan drift.

This drift has surface features of a sufficiently definite character to make it feasible to map its limits within a mile or less throughout its exposed portion in Iowa, Minnesota, and South Dakota, or for a length of fully 200 miles. The district outside its limits is markedly more eroded than that inside. The outlying district lacks the knolls and ridges of constructional type that characterize this drift. On this later drift gravelly knolls or kames are common features. There are also extensive deposits of gravelly outwash along its border from which gravel trains lead down valleys that had been opened widely by previous erosion of the Kansan drift.

Geol. Soc. America Bull., vol. 33, flg. 1, p. 103, 1922.
The gumbotil that forms so conspicuous a feature on the surface of the Kansan drift in southern Iowa has not been noted in northwestern Iowa and neighboring parts of Minnesota and South Dakota, either inside or outside the limits of the drift under discussion. This fact and the fact that the later drift is of similar constitution to the Kansan drift and was probably in large part derived from the Kansan drift make it difficult to separate them in places where one

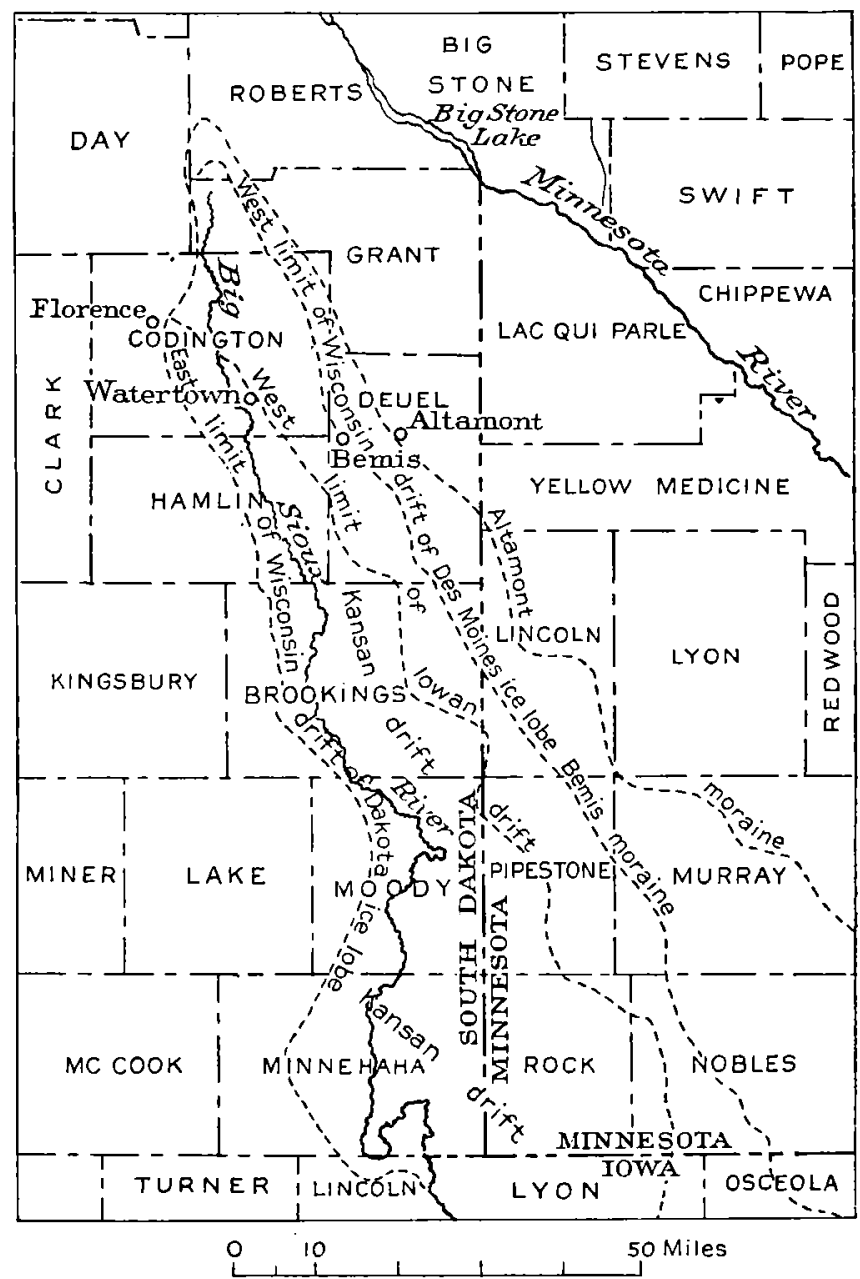

FIGURE 6.- Sketch map showing extent of Iowan and Wisconsin drifts in southwestern Minnesota and eastern South Dakota

is exposed above the other. In much of the area, however, the later drift has a much fresher aspect than the Kansan, being grayish yellow rather than yellowish brown.

Beginning at the north, the border of this drift is found to emerge from beneath the outer moraine of Wisconsin drift of the Dakota lobe about 3 miles east of Florence, Codington County, S. Dak. (See fig. 6.) The drift is exposed for about 20 miles farther north, chiefly on the east side of the Big Sioux River, and fills the interval between the Bemis moraine of the Des Moines lobe and the outer Wisconsin moraine of the Dakota lobe. 
The western or outer border passes to the east side of the Big Sioux River about 5 miles above Watertown and follows the river southward to Appleby, 6 miles below that city. It then bears away from the river southeastward across the northeastern part of Hamlin County and the southwestern part of Deuel County, about to Toronto, S. Dak. There the border turns southward and lies along or near the Chicago, Rock Island \& Pacific Railroad as far as Bushnell, whence

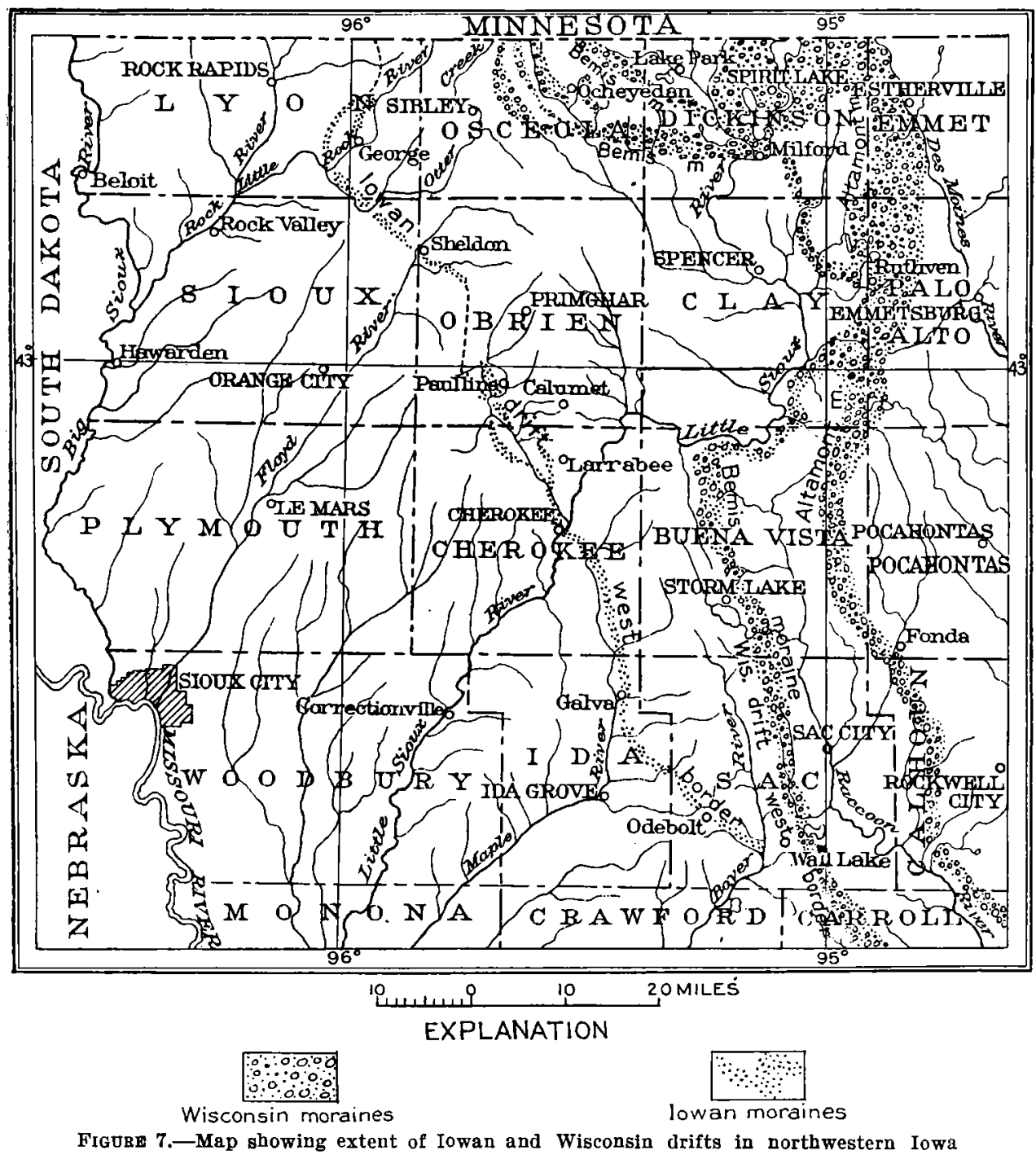

Lismore and Adrian and a similar distance east of Ellsworth, Minn.

In Iowa (see fig. 7) the border runs southward through the western part of the northeast township of Lyon County and then takes a southwestward course, passing 2 miles west of George and crossing the Little Rock River about 3 miles below that village. A turn is then made to the southeast, and the border lies along the north side of Otter Creek to the bend in the creek 2 miles west of Matlock. Thence it runs southeastward to the Floyd River at Sheldon and continues in the same course to Archer. It then runs southward for 9 miles, crosses the Chicago \& Northwestern Railway about 3 miles west of Paulina, extends along or near Mill Creek to Cherokee and the valley of the Little Sioux River, crosses to the east side of that valley and takes a southeast course to the Maple River 3 miles southwest of Aurelia, follows the east side of the Maple River southward as far as Galva, and bears southeastward past Odebolt to the Boyer River 2 miles west of Wall Lake village. An outwash plain and a glacial drainage channel from the Wisconsin drift border fill in the space to that border, a distance of 3 miles. The drift under discussion is not known to appear outside the Wisconsin drift border farther south.

The border as above outlined was carefully traced by the writer from its emergence from under the Wisconsin drift near Florence, S. Dak., it swings eastward to the Minnesota line about 2 miles northeast of Elkton, S. Dak. It runs southward near the State line past Elkton and Ward to the valley of Flandreau Creek before turning into Minnesota. In Minnesota it bears southeastward past Pipestone nearly to Edgerton and then follows the west bluff of Rock River southward into Rock County. It bears eastward from Rock River across the northeast township of Rock County, passing 2 miles north of Kenneth. On entering Noble County it turns southward and traverses the western range of townships for 20 miles, to the Iowa line, passing about 3 miles west of southward across southwestern Minnesota into Iowa as far as Cherokee. But from Cherokee southward to Wall Lake, where it passes under the Wisconsin drift, only a rather hasty trip by automobile was made, in company with J. E. Carman. This trip followed a zigzag course back and forth across this border, which enabled the writer to note the contrast in erosion in the districts on the two sides of the line and the main characteristics of this part of the drift border. At the time this trip was made Carman was of the opinion that a post-Kansan drift is present and has the limits here outlined. In his report fea- 
tures that suggest post-Kansan age are referred to, as may be seen by the following quotations, though at the time of its publication he considered the evidence inconclusive. ${ }^{.9}$

This area and that to the northeast have at many places small features that appear to be constructional. They are located on surfaces of more distinct erosional features, giving to the slopes a somewhat uneven or billowy appearance. These features suggest that a later ice sheet overrode the region at a time when it had an erosional topography and left a thin but uneven veneer of drift. Such an explanation was carefully considered during the progress of the field work. It was not

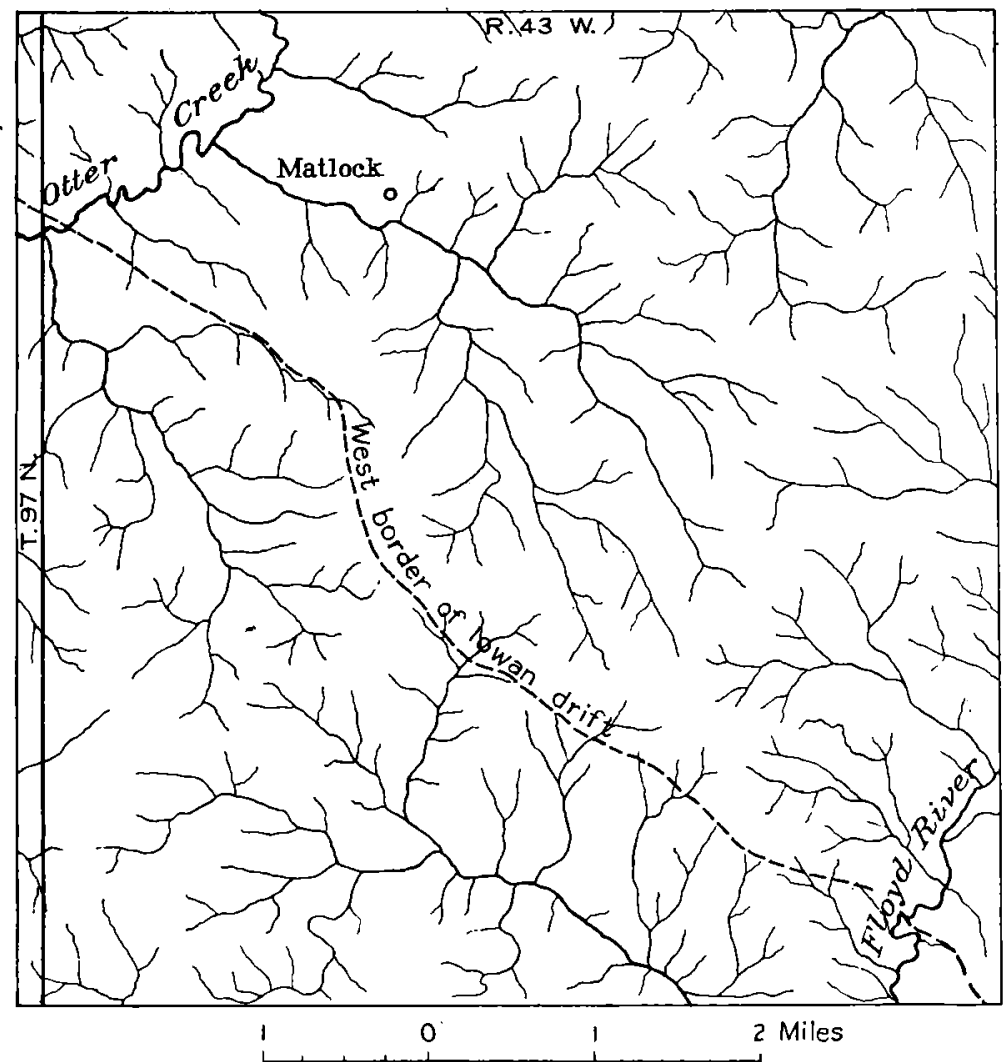

Fiaure 8.-Map of the northeast township of Sioux County, Iowa, showing drainage development on each side of the west border of the Iowan drift
In the district west of this drift border the valleys have broad, gentle side slopes, with a descent of 60 to 80 feet or more in a width usually of over half a mile. The slopes are not only long but are unbroken by knolls or ridges suggestive of glacial readvance. Inside the drift border there is a filled-up appearance, and the valleys lack the characteristic erosion curves. As expressed by Meinzer, ${ }^{60}$ in discussing the drainage features in O'Brien County, Iowa, "the smaller streams have not yet dissected the plain to any great extent but occupy broad, shallow, and rather indefinite

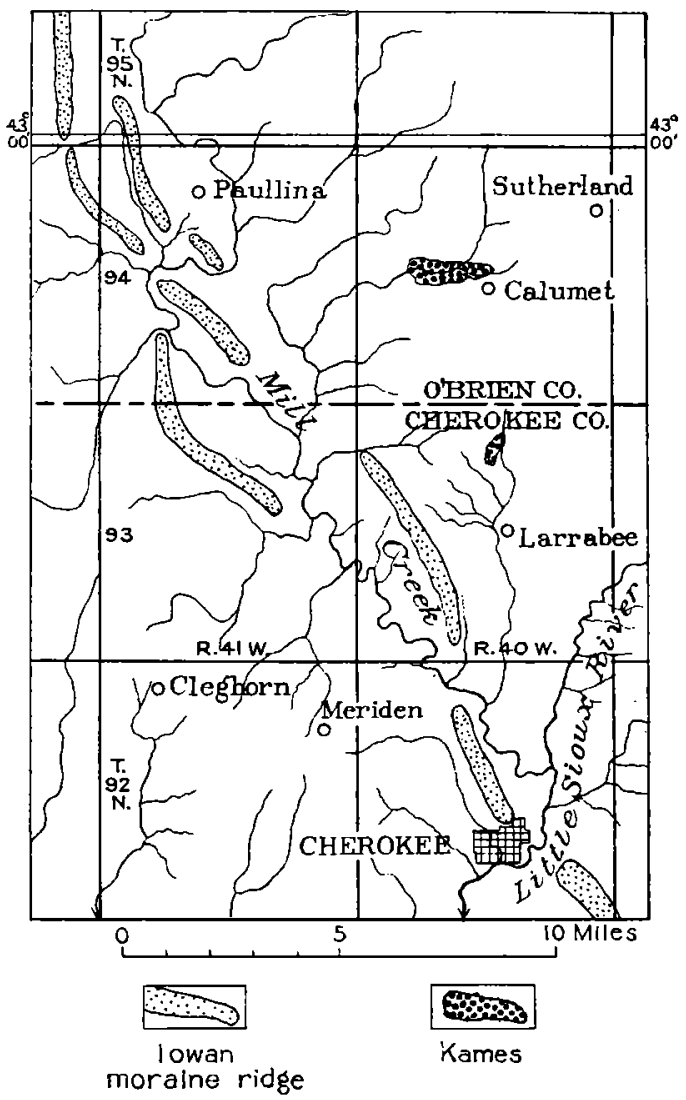

EIGURE 9.-Drainage deflections in northwestern Iowa due to Iowan ice invasion

possible, however, to differentiate a drift material or find a definite southwest boundary for these apparently constructional features.

At many places within the Kansan region, a drift somewhat lighter in color than the typical Kansan is to be found. It is yellowish gray or brownish gray instead of the usual brownish yellow. However, the difference is not distinct, and it seems there are all gradations. Commonly this lighter-colored till contains considerable pebbly material scattered through it and has associated with it lenses and beds of gravel. This phase of the till is found in a number of exposures north of Cherokee, as in the bluffs of Mill Creek in sec. 14 ; as a layer of till in the pit of the Cherokee Sand \& Gravel Co.; and in the NW. $1 / 4$ sec. 13, Cherokee Township, on the farm of $M$. Doupe. North of Cherokee County this phase is commonly present and is the usual till material.

שo Carman, J. E., Iowa Geol. Survey Ann. Rept. for 1915, pp. 325, $335,1917$. valleys, through which they habitually meander lazily." The widely branching dendritic drainage pattern which had been developed on the Kansan drift before this later drift was laid down is reproduced almost completely but as a series of shallow swales. (See fig. 8.) These swales afford lines of discharge for the surface water, but the discharge is so slow that it has been found necessary to put in a large amount of tile drain along them. Tiling is seldom required in the district outside the limits of this drift.

Some slight deflections of drainage have been caused by the building of drift ridges across the old stream courses, as on Mud Creek near Paullina, Iowa (fig. 9), and on a small tributary of the Little Sioux River

${ }^{60}$ Meinzer, O. E., Iowa Geol. Survey, vol. 21, p. 1059, 1912. See also U. S. Geol. Survey Water-Supply Paper 293, p. 864, 1912. 
north of Cherokee. But the drift ridges and knolls of this post-Kansan drift have caused very few deflections in the drainage courses.

Some drainage deflections of a higher order may have resulted from this ice invasion, but these Carman has referred to a later time. Thus, the Little Sioux River as far down as southern Clay County appears to have been from Kansan time to Iowan time tributary to the Des Moines River instead of to the Missouri River. Its headwaters are east of the high ridge that farther north and also farther south forms the divide between the Missouri and Des Moines drainage old divide a short distance southwest of Gillett Grove, between tributaries of the Des Moines. From a point a few miles above Cherokee to its mouth the course is evidently that which had been developed by a tributary of the Missouri River. It is, however, partly filled with Iowan drift as far down as Cherokee, and only below that city does it present the broad, gentle side slopes characteristic of the post-Kansan drainage.

Mill Creek, which enters the Little Sioux at Cherokee, shows the effect of the Iowan glaciation along its entire length, for only a short section of its valley, a few miles above its mouth, escaped covering by the

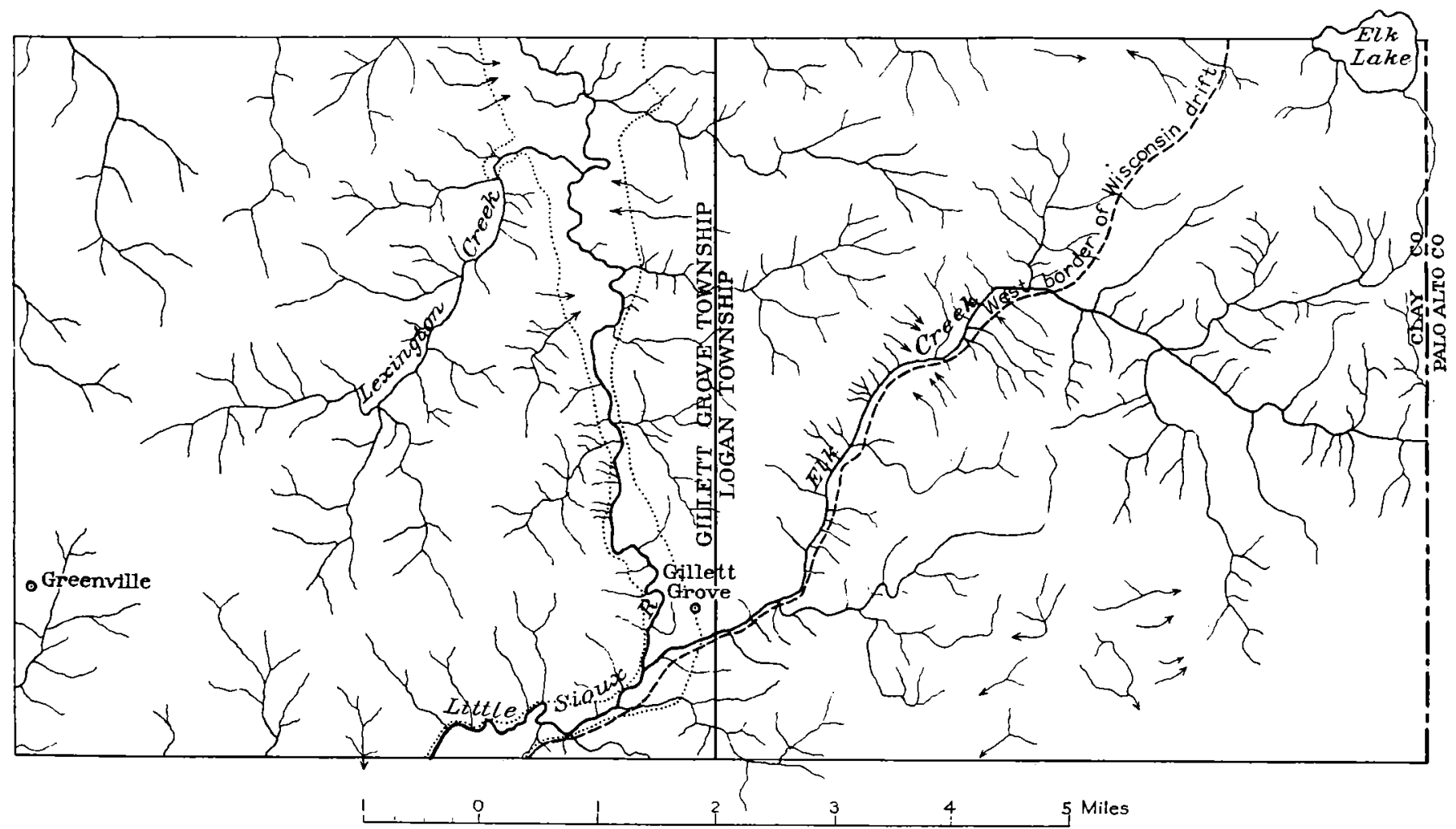

Figurw 10.- Map showing relations of drainage in Gillett Grove and Lcgan Townships, Clay County, Iowa, to the outer terminal moraine of the Wisconsin drift. Dotted lines show limits of Little Sioux Valley

systems. As suggested by Carman, ${ }^{61}$ this old drainage seems to have been deflected across a divide near Gillett Grove, where the valley is now exceptionally narrow. (See fig. 10.) From that point to the northeastern part of Cherokee County the valley is narrow and deep and perhaps only to a slight degree coincident with the earlier drainage course. The height of land is greatest 20 to 25 miles west of Gillett Grove, below the mouth of Waterman Creek, and it is not improbable that the drainage as far down as Waterman Creek, inclusive, was once tributary to the Des Moines River, but the line of discharge is not clearly cietermined. It may have been along or near Brooke Creek (reversed) to Storm Lake and thence eastward to the Raccoon, now tributary to the Des Moines River. In that event the Little Sioux may cross an

¿1 Carman, J. E., op. cit., pp. 310-318.
Iowan ice sheet. (See fig. 9.) As a result of this glaciation its valley has been filled to a marked degree by the Iowan drift, chiefly sorted material, and is strikingly out of harmony with its western tributaries, which are opened to a breadth and depth characteristic cf post-Kansan erosion. This contrast was noted and clearly set forth by MacBride ${ }^{62}$ in the following statement:

We have already had occasion to mention the differences between Cherokee and Buena Vista Counties; but even in Cherokee County the difference in form, in relief, between the steep boulder-strewn slopes in Cherokee and Cedar Townships and the fair and long-sloping loess-covered hillsides of Rock and Tilden Townships is not only patent but seems sufficiently striking to awaken the interest of every student, not to say every intelligent farmer.

az MacBride, T. H., Iowa Geol. Survey Ann. Rept. for 1901, pp. 311-312, 1902. 
Everywhere, especially to the northeast, the topography of Cherokee County has been profoundly modified by close association with a topography of an entirely different character, as will appear in what is here to follow. The topography, indeed, seems to be all erosional; but the typical and pure sculpture of the erosion model does not appear north and east of the mouth of Mill Creek Valley.

Especially north of Cherokee the banks of the river valley are everywhere marked by gravel terraces far above the flood plain of the present stream, sometimes as much as 100 feet above it. Such deposits are not the effect of ordinary erosive process. There is every evidence that the channel of the river had been fully excavated long before these deposits came to place. ***

The presence of these gravel trains affects the topography in yet another way; the gravel has not only in many places filled up and obliterated older erosion features, but it has itself been subject all the while to the processes of erosion. This often brings about a superposition of a newer topography directly against or upon one a great deal older. We encounter evidence of recent change, of newness and youth, where we should naturally expect the reverse. The walls of the river valley to the north everywhere show this. Old tributary streams have been choked across, and new channels later excavated, sometimes-generally, indeed-in the direction of the older valley; not always. The banks of Mill Creek show all these same erosion peculiarities; high terraces of gravel cut by recent steep and short erosion channels. * * * Everywhere the gravel along the principal stream has filled the mouths of incoming valleys and then been again cut ont, so that the mouth of any tributary valley is apt to be the narrowest part of it.

The Mill Creek drainage system is entirely west of the highest ridge of that region and has probably suffered only slight shiftings from courses held by the streams prior to this later (Iowan) glaciation. It was probably the main headwater part of the Little Sioux of that earlier time.

Another notable shifting of drainage, suggested by Carman, is that of the headwater part of the Boyer River. From its source to the Wall Lake outlet, in southern Sac County, the Boyer is flowing through a district east of the highest ridge that slopes toward the Des Moines Valley, and probably at one time it turned into that valley near this channel. But it now turns southwestward and cuts across the high ridge near Herring, thus lengthening out a valley discharging to the Missouri that once headed near Herring. This old valley exhibits the broad, gentle side slopes that are characteristic of the post-Kansan erosion.

The deflection of the headwater part of the Boyer River from the Des Moines drainage basin into that of the Missouri is thought by Lees ${ }^{63}$ to have been independent of glaciation and due to stream capture by the headward lengthening of the southwestwardflowing part of the river, at a time prior to the Wisconsin stage of glaciation. The shallowness of its valley he accounts for by its situation on the back

6ees, J. H., The history of Boyer Valley: Iowa Acad. Scl. Proc., vol. 26, pp. 493-500, 1920. side of the prominent divide across which he supposes it was deflected by stream capture. He makes no mention of the presence of a post-Kansan drift in this headwater portion.

It is probable that these drainage lines that were formed on the east side of the prominent old divide had somewhat shallower channels than those on the west side, but this relation seems to account for only a part of the difference. In the writer's opinion the filling with post-Kansan drift is the main factor in causing the shallowness of the valleys. That this is so may be seen by examining valleys in Lyon County, Iowa, and in southwestern Minnesota which are inside the limits of the Iowan drift but are entirely west of the prominent old divide. In valleys such as those of the Rock and Little Rock Rivers, Kanaranzi Creek, and Flandreau Creek the headwater parts, inside this post-Kansan drift, are shallow and small, but the lower parts, outside this drift, are large and deep, and the change sets in at this drift border.

The shifting of these old drainage lines from the Des Moines or Mississippi to the Missouri River is assumed by Carman to have been effected in the Wisconsin stage of glaciation-that is, at the time the Bemis moraine was formed. It seems quite as likely to have occurred, however, at the earlier time when the Iowan drift was brought in by ice that filled the Des Moines drainage basin.

The Iowan drift of Nobles, Rock, and Pipestone Counties, Minn., occupies a narrow strip outside the Bemis moraine of Wisconsin drift, on the western slope of the Coteau des Prairies. (See fig. 5.) This slope has had drainage to the Missouri through the Big Sioux Valley and eastern tributaries from Kansan time on and thus has been favorably situated for the development of capacious valleys, such as are found in the western part of Iowa. The Iowan drift has blanketed the valleys and the intervening ridges or divides, but they still stand out as the prominent features of the topography. The courses of some of these old valleys are not directly down the slope toward the southwest but southward for several miles before turning southwestward. Thus a valley now drained by the north branch of Kanaranzi Creek leads southward to Adrian, Nobles County, with a prominent ridge on its west side, and then takes a southwest course to the Rock River Valley. Between Adrian and Rushmore another valley starts in, a southward course to the Little Rock River, with a prominent ridge on the east between it and the headwater part of the Little Rock Valley and another on the west that runs southward into Iowa and drops off near Little Rock, where the stream turns southwestward. Similar southward courses of the upper parts of valleys are found in southwestern Murray County, Minn., 
and an especially conspicuous example occurs in eastern Pipestone County, where for more than 20 miles the Rock River takes a southward course between prominent ridges on the east and west. Still farther north, in southern Lincoln County, Flandreau Creek runs southward from Lake Benton, with a prominent ridge on the west as far as Verdi.

These ridges do not seem to represent moraines nor the valleys intermorainic depressions, but instead they seem to have been erosion features developed by postKansan drainage prior to the Iowan ice advance. The border of the Iowan drift is in places nearly coincident with interstream prominences, but it passes from these prominences down into the valleys and across them to other prominences in its course from northern Iowa across southwestern Minnesota into South Dakota. The valley slopes and bottoms now present irregularities of contour due to the later drift, and in places a subdued morainic topography is to be seen. The valley of Kanaranzi Creek west of Adrian contains numerous small knolls of the later drift, and scattered small knolls are found on the bordering uplands in and near Adrian. A more common feature along the border as well as back within the area of this later drift is a very gently undulating surface. It is found on valley slopes and on the divides as well. The effect of this later drift has been to fill the old valleys in part, as well as to give diversity to their slopes. It thus becomes an easy matter to fix the limits of this drift, even where there is no definite moraine at the border. The average amount of drift in the later advance may be but 10 to 20 feet, to judge by the appearance of the old ridges and valleys inside the drift border compared with their continuations outside.

An interesting development of a new drainage line in this later drift was noted about 4 miles east of Pipestone. A small stream heads there and leads southward past Hatfield. Its course is winding and it has cut across the rims separating basins that form a chain leading toward Hatfield. The basins are 10 to 15 feet deep, and this stream has made sharply incised cuts across the spaces between them. These basins and the narrow connecting channels are features of youthful drainage inconsistent with the interpretation that the drift in which they are cut is of Kansan age. This valley is fully 10 miles outside the Bemis moraine of Wisconsin drift and 4 or 5 miles inside the limits of the Iowan drift.

Knolls near the waterworks tank in Adrian and others a mile or more to the west contain a mixture of fresh drift with weathered material from the underlying Kansan drift. In forming the knolls the gravel beds have been in places shoved into steeply inclined positions. In the knoll by the waterworks tank the southern part shows undisturbed old gravel resting on old (Kansan) till. The higher part of the knoll shows a jumble of beds of weathered gravel, with fresher material to a depth of 25 to 30 feet. Silt and sand beds are also shoved into an inclined position and then covered with fresh gravel. Over the surface of this knoll there is a very bouldery coating of slight depth.

From the vicinity of Pipestone northward into Lincoln County, Minn., there are ridges overridden by the Iowan glaciation, separated by broad nearly plane tracts 50 to 75 feet lower than the ridges. The ridges usually trend northwest, nearly parallel with the crest of the Coteau des Prairies. Their relief is thought to be due mainly to erosion of the bordering swales prior to this ice invasion, but knolls on the slopes seem due to some degree to deposition of drift at this later glaciation.

In Brookings and Deuel Counties, S. Dak., the district in which Iowan drift is exposed (outside the Bemis moraine) embraces a prominent part of the Coteau des Prairies, standing in places higher than the crest of the Bemis moraine. The highest points in the vicinity of Toronto are about 2,000 feet above sea level, the railway station being 1,996 feet. 'There is a gently undulating surface. on the highest land covered by this drift, as well as on the slopes and to some extent in the broad swales between the high areas. Sharp knolls such as characterize the Bemis moraine are very rare. In eastern Codington County, S. Dak., there is a high tract running northward through central Kranzburg Township, its highest points being 1,950 feet or more above sea level, on which boulders are exceptionally numerous, and the surface has the gentle undulations of a ground moraine. It is strikingly in contrast with the strongly morainic topography of the Bemis moraine, on the east, and also is perceptibly different from the area of Kansan drift to the west of the Big Sioux Valley, both north and south of Lake Pelican. (See fig. 5.) The Kansan drift has a thin deposit of loess in this region, but there is little or no loess or silt loam on the Iowan drift.

About 2 miles east of Watertown, S. Dak., on the border of Willow Creek, there are sharp gravelly knolls or kames, 30 feet or less in height, which so fill the valley that the bottom land is reduced to a width of only 30 rods, although above and below this place it is a quarter of a mile or more in width. These kames appear to be constructional features due to the Iowan glaciation. They stand only 1 to 2 miles inside the limits of the Iowan drift.

Directly north of Watertown the Iowan glaciation probably formed a low ridge of till situated along the east bluff of the Big Sioux River. This ridge diverts 
the drainage away from the east bluff, partly to a small stream that flows southward into the eastern part of Watertown, partly to a stream that leads northward to the Big Sioux.

Between the Big Sioux and Gravel Creek, an eastern tributary, there is a very flat till plain covering several square miles in Rauville and Germantown Townships, which is within the limits of the Iowan drift. Between this plain and the Bemis moraine there is a higher and more rolling strip of country about 6 miles in width, on the western slope of the Coteau des Prairies. Its strong erosion features are partly masked by the knolls of Iowan drift, as in the district south of Watertown.

West of the Big Sioux River, in northern Codington County, S. Dak., there is a narrow strip of gently undulating post-Kansan drift. This is overridden by the outer moraine of the Dakota lobe of the Wisconsin glaciation 2 to 4 miles west of the river. Its border passes beneath the moraine directly north of Still Lake, 3 miles east of Florence. South of Still Lake there is Kansan drift with broad erosion features, but north of the lake the erosion features are masked by the Iowan drift. There is 2 to 4 feet of silt loam or loess on the Kansan drift that conceals the boulders and till, but on the Iowan drift boulders and till are well exposed, as scarcely any silt loam is present.

Lake Kampeska and Pelican Lake occupy depressions at the east border of which there are gravel deposits brought down the Big Sioux Valley. These are probably in part of Wisconsin age, but some of the gravel stands a little above the level of the Wisconsin valley train and may pertain to the Iowan drift.

In a field conference in 1925 by G. F. Kay, Paul MacClintock, E. R. Apfel, and the writer, exposures were found near Sheldon, Iowa, in which the drift under discussion is separated from the underlying Kansas drift by a thin deposit of loess. It is also overlain by loess. Two exposures were noted, one on the line of sections 4 and 5, Carroll Township, O'Brien County, and the other on the line of sections 4 and 9 of the same township. At the latter the till is only 1 to 3 feet thick. It is thickly set with pebbles and is very calcareous throughout. The loess above it is about 3 feet thick and has been completely leached. The loess beneath this till was penetrated with a post auger to a depth of $4 \frac{1 / 2}{2}$ feet. It has a drab color and is but slightly calcareous near the top, but at $3 \frac{1}{2}$ feet it becomes highly calcareous. This loess was found to have a thickness of 8 feet in a cistern at a neighboring farm house in the northern part of section 9 . West of Sheldon a till of much fresher aspect than the Kansan drift was noted on the line of sections 25 and 36 , Grant Township, Sioux County. Its color is grayish yellow; that of the Kansan drift is a brownish yellow. An exposure of similar fresh appearance was noted 4 miles south of George, on the line of sections 25 and 26, Wheeler Township, of which samples were taken by Kay for laboratory study. All these exposures are in the outer ridge of the Iowan till, within a fraction of a mile of its limits. This terminal ridge, though only 10 to 25 feet high, is distinctly traceable for many miles in that part of Iowa.

Although the Iowan drift in this district west of the Des Moines lobe of Wisconsin drift has a more definite border than that east of this lobe, it seems to have no recessional moraines and is generally a very scanty deposit. These conditions make it seem probable that this part of the Iowan ice sheet also became stagnant soon after reaching its culminating position.

\section{OUTLYING GRAVEL PLAINS}

Gravel plains are conspicuous features on the outer edge of the Iowan drift and seem to sustain the relation of outwash aprons, developed while the ice was at its farthest limits. They are especially conspicuous in Brookings County, S. Dak., where they extend 2 or 3 miles from the border of this drift and form a nearly continuous fringe. Elsewhere in South Dakota and in the Minnesota and Iowa portions of this drift border gravel trains lead down nearly every valley that heads within its limits, but there is little gravel on the interstream areas. On Mill Creek and the Little Sioux River for a few miles above their junction, at Cherokee, Iowa, gravel forms the main filling of the valleys but is to some extent interbedded with till, as these valleys lie within the edge of this drift. Below their junction a gravel train extends down the Little Sioux Valley. An extensive gravel plain is found along Champepadan Creek east of Kenneth, Minn., similar to those of Brookings County, S. Dak. This plain is trenched to a depth of 40 or 50 feet by the creek, but the trenching was perhaps done mainly by the glacial drainage from the Bemis moraine of the Wisconsin stage, which crosses the creek a few miles farther up. In several of the valleys in Minnesota the gravel trains that head in the Iowan ice border stand distinctly higher above the present streams than those that head in the Bemis moraine, thus indicating an interval of some length between their times of deposition. Yet the terraces marking the filling at the earlier deposition have far less toning down than the valley slopes of the Kansan drift area outside and also bordering the gravel filling.

The weathering of the gravel deposits that connect with the Iowan drift is very distinctly greater than that of the deposits that connect with the Bemis moraine, of Wisconsin age. There is usually a deep rusty-brown stain in the former to a depth of several feet, whereas the gravel connected with the Bemis 
moraine has a fresh gray color nearly to the surface. The erosion of this gravel and the degree of weathering it displays seem inconsistent with Wisconsin age. These features are more conspicuous in the gravel deposits than in the till deposits under discussion, which do not show so striking evidence of greater age than Wisconsin. It is probable, however, that the gravel is a deposit of streams from the same ice that laid down the till, and not the product of earliel stream work, though part of the gravelly material along these valleys may have been laid down as a concentrate of erosion prior to the time of the ice invasion that brought in the fresher till. Some of this material seems to have been involved in the valley filling that accompanied the ice occupancy.

\section{PEBBLE CONCENTRATE AND WEATHERED ZONE ON IOWAN DRIFT}

The alteration of the surface of the Iowan drift by weathering is less conspicuous than that of the Illinoian drift of western and southern Illinois and southeastern Iowa. In the latter region a gumbotil is somewhat prevalent and is developed to a depth of 2 to 5 feet. But on the Iowan drift in southwestern Minnesota and adjacent parts of Iowa and South Dakota there seems to be little or no gumbotil. Instead there is either a pebbly concentrate or a leached and weathered till surface. These features seem to call for an interglacial stage of at least moderate length. Where loess is present some erosion and weathering occurred prior to the deposition of the loess. Further study of the weathered surface of the till and the pebbly concentrate is necessary to determine whether or not they are the full equivalent of the Sangamon soil and the Illinoian gumbotil.

Should the Iowan and Illinoian drifts prove to be referable to the same stage of glaciation, the main loess deposit will fall in the succeeding interglacial stage, as it is older than the Wisconsin stage, and the Sangamon and Peorian times of weathering, as well as the main deposition of loess, will fall in a single interglacial stage, the Sangamon standing for the earlier and the Peorian for the later part of this interval.

\section{LOESS OF UPPER MISSISSIPPI VALLEY}

A belt of loess extends down the Mississippi Valley along the east side of the Iowan drift area. Geologists who investigated this belt at first thought that it was due to certain drainage conditions, either lacustrine or fluviolacustrine, attending the glaciation on the border of the driftless area. The fact that in eastern Iowa loess strips extend long distances up certain valleys tributary to the Mississippi but do not cover the interfluvial tracts so far back was thought to support this interpretation of loess as a drainage product. The loess-free strips along certain other valleys were referred to the persistence of ice lobes in those valleys. To explain the deposition of loess on isolated prominences, surrounded by loess-free lowlands, it was commonly assumed that ice persisted on the lowlands and that water issuing from it covered the exposed prominences and laid down the loess.

As studies progressed, however, it was found that the loess covers too wide a district to have been hemmed in by ice barriers. It borders the Ohio as far east as West Virginia, and a broad belt extends from Iowa and Missouri as far west as Colorado. Loess also borders the east side of the Mississippi southward to the Gulf of Mexico. There is no land barrier at the south to have ponded the waters, and there is no evidence of such widespread epeirogenic movement in the Mississippi Basin as would cause a belt of country extending from West Virginia to Colorado to become too low for fluvial drainage. In short, the great extent of the loess, together with its topographic relations, shows that it is not a water deposit.

The study, notably by Shimek, of fossils included in the loess brought out clearly the terrestrial as opposed to the aquatic origin of the shells, Helicina, succinea, etc. As a result of its geographic and paleontologic features the loess has come to be regarded in America, as it has long been regarded by most of its students in other parts of the world, as an eolian deposit, dependent only locally and in a secondary way on fluvial action. In the region under discussion it is doubtful if fluvial action has contributed to any great extent, except secondarily, in furnishing loess material.

The question next arises whether the loess is a glacial or an interglacial deposit. The portion in eastern Iowa seemed to McGee and also to Calvin and his assistants so definitely related to lobes of ice that its glacial age was inferred. It was also at first thought that the fossils were sufficiently depauperate to bring support to the glacial interpretation. The later study of fossils by Shimek, however, not only failed to establish the depauperate condition, but iristead brought him to the view that the mollusks lived in a temperate climate such as now characterizes the region. The loess of this region seems to fall into a position such as is assigned to the interglacial loess of the plains of Russia, formed during what is called the steppe phase of interglacial climate to distinguish it from the forest phase of cooler climate that preceded the deposition of the loess. ${ }^{64}$

Southward from the hilly or deeply dissected districts of southeastern Minnesota on the smoother tracts of southeastern Iowa and western Illinois the Sanga-

6 Bogoljubow, N. N., Ueber die Phasen der interglacialen Epoche im Gouvernment Moskau: Annuaire géol. et min. de la Russie, vol. 9, p. 43, 1907. 
mon soil forms a conspicuous feature between the loess and the underlying till. Such of the woody material in this soil as has been studied suggests cool temperate climate, similar to that of the forest phase of the European interglacial stage. In the hilly loesscovered district in southeastern Minnesota and northeastern Iowa the surface is in few places flat enough to favor the development of this interglacial soil. Only 6 out of the 200 soil records presented by McGee in his paper on northeastern Iowa ${ }^{05}$ seem to represent the forest phase preceding the loess deposition-Nos. $29,65,114,164,174$, and 175 . There is, however, very commonly a concentration of pebbles at the base of the loess and on top of the Iowan drift, which seems to stand for an interval of erosion between the disappearance of the Iowan ice and the deposition of the loess.

It is doubtful whether the loess deposition in the upper Mississippi region occurred at a time when the region was destitute of forests. In fact, arborescent vegetation is thought by Shimek and others to have determined the extent of loess retention, the prairie regions being too strongly swept by winds to permit the atmospheric dust to find permanent lodgment. It is probable, however, that there was in the region to the west, from which the winds came, sufficient aridity to warrant the application of the term steppe.

The loess presents some variation in color and texture from top to bottom, which has given rise to the question of its separation into distinct deposits of different age. Thus the basal portion not uncommonly differs from the ordinary loose-textured buff-brown loess in being close-textured and bluish and in having the iron segregated along joints or in pipes, like old root cavities. Calvin considered this phase a distinctly older one than the ordinary loess and cited the iron segregation as an evidence of the greater age. This bluish phase is found only where the loess is exceptionally thick and in many places where it seems to fill a depression in the till. It is, however, in general not sufficiently well exposed to exhibit the full topographic relations. The writer has never found evidence of unconformity between the brownish and bluish loess-in fact, there generally seems to be strict conformity in the bedding of the two deposits. The differences displayed are therefore perhaps due to difference of conditions attending the deposition. The bluish loess may have been laid down where imperfect drainage conditions prevailed. With the removal of these conditions, perhaps by the filling of a depression, a change in texture might result, and the ordinary permeable loess might be laid down. In some of the paha ridges a bluish loess has been noted which

${ }^{05}$ McGee, W J, U. S. Geol. Survey Eleventh Ann. Rept., pt. 1, pp. 514-540, pl. 51, 1891. is as loose textured as the overlying brown loess. In such places the brown loess has the appearance of being merely the oxidized portion and the blue loess the unoxidized portion of a single deposit.

Here and there are exposures of a reddish loess, resting directly on till, overlain usually by the ordinary buff-brown loess but in some places by bluish loess, as in an exposure directly east of Lamotte, in Jackson County, Iowa. A sample of red loess from a place near Sterling, in southern Jackson County, was sent by the writer to R. T. Chamberlin for microscopic examination. He found considerable limonite in the form of ferric oxide, or hydroxide, disseminated through the deposit. The coloring matter seems not to be a superficial stain, for neither boiling nitric acid nor boiling aqua regia destroys it appreciably. It appears unlikely, therefore, to be due to $\mathrm{Fe}_{2} \mathrm{O}_{3}$. The color seems to Chamberlin instead to be due to the presence of a pink or reddish silicate, such as orthoclase.

As a rule the ordinary buff-brown loess does not contain fossils, but a peculiar phase of the loess, best developed along the borders of valleys and known as "bluff loess," contains fossils in large numbers. It is this loess that is conspicuous in the ability to resist frost action and thus to stand in vertical walls for long periods and to retain inscriptions carved in it. This phase of loess is sometimes found in the pahas of northeastern Iowa.

One of the most puzzling questions in connection with the loess of the upper Mississippi region is its interrupted or patchy condition. Elsewhere it forms a practically continuous sheet, the breaks in it being due to removal by streams, but in the region west of the Driftless Area it is patchy in situations where conditions seem well suited for its retention and nearly continuous on some of the deeply dissected tracts with steep hillside slopes. If the old idea of ice occupancy of the loess-free tracts held by McGee and Calvin is ivcorrect, as now seems probable, the peculiar distribution is probably to be explained by some exceptional combination of wind action and vegetal conditions. The meteorologic conditions that gave rise to the deposition of loess, as well as the peculiarities in the distribution of the loess, present a most inviting field for speculation and investigation.

\section{LOESS WEST OF THE DES MOINES LOBE}

The loess deposits west of the Des Moines lobe of the Wisconsin drift in northwestern Iowa, southwestern Minnesota, and eastern South Dakota show clearly that they were deposited by winds from the southwest. The Missouri River bottoms as well as the semiarid plains to the west seem to have contributed material for the wind to transport eastward. Studies by F. J. 
Alway and C. O. Roost ${ }^{66}$ have shown that in Nebraska the loess becomes of finer texture from west to east, also that on the east side of the Missouri Valley a coarser-grained, more readily pervious loess begins, which likewise becomes finer eastward. The thickness of the loess is much greater in southwestern Iowa than in northwestern, clear up to the border of the Wisconsin drift. The decrease in thickness from western Iowa northward into Minnesota is due to getting out of range both of the material gathered in the Missouri bottoms and of the material carried eastward from the semiarid districts.

Considerable dust is now being carried by the wind across this region and lodged in sheltered places, and it should be distinguished from the loess brought in before the Wisconsin glacial stage. The recent material can usually be recognized by its lack of homogeneity, there being in it coarse and fine sand particles as well as finer material, whereas the older loess in its original state carried nothing coarser than very fine sand. Any coarse material now found embedded in it is of secondary nature and an evidence of redeposition.

\section{RELATIVE AGE OF LOESS AND IOWAN DRIFT}

The relative age of the loess and of the glacial features that have been classed as pertaining to the Iowan drift is a problem of prime importance, for upon its proper solution seems to hang the verity of an Iowan stage of glaciation distinct from the Illinoian stage. At first the loess was closely correlated with the Iowan drift and hence was termed Iowan loess. But the advocates of an Iowan stage of glaciation later came to regard the loess as a somewhat younger deposit. Thus in the last paper on the subject by Calvin, ${ }^{87}$ published after his death, the following statement is made:

The Iowan loess is related to the Iowan drift in much the same way that the gravels are related to the Kansan. The earlier view was that the loess was deposited at the time of maximum development of the Iowan glaciation, when the Iowan area was still covered with ice. The only modification of that view at the present time is that loess deposition took place after the Iowan ice had retreated to a greater or less extent, after an interglacial interval had actually begun. By such retreat extensive mud flats were left, and as these dried before becoming covered with vegetation, strong winds coming, probably, from the ice fields to the north carried fine sand and dust from the bare surfaces and deposited them beyond the edge of the Iowan area, out upon the old, eroded Kansan. * * * The color, composition, and calcareous content of the Iowan loess are in perfect accord with the hypothesis just expressed; its geographic distribution around the lobed margin of the Iowan area agrees also with the view; the great thickness of this loess at and near its margin and its thinning out with increasing distance from the source of supply corroborate all the other lines of evidence; while the great amount of eolian sand associated with it in a narrow belt surrounding

Soll Science, vol. 1, pp. 405-430, 1916.

ar Calvin, Samuel, The Iowan drift: Jour. Geology, vol, 19, pp. 601-602, 1911. the lobes of Iowan drift lends additional support. * * * Studies in the field afford overwhelming evidence that, genetically and geographically, the Iowan drift has very intimate relations to certain bodies of loess.

The following statement is made by Alden and Leighton ${ }^{88}$ as to the relation of the Iowan drift to the overlying loess :

In the area of the Iowan drift the loess is generally so thin that the leached zone extends down into the till. None of the exposures or borings revealed calcareous loess overlying leached till. On the other hand, at least one section, in an interurban cut near Lisbon, Linn County, exposed calcareous till immediately beneath calcareous loess and sand. ***

Relations similar to these were found by making borings in the southwestern part of the Iowan drift area, in Benton, Tama, and Grundy Counties. The loess in this latter territory is thicker than in the rest of the Iowan area and lies as a general mantle with an average thickness of 4 to 6 feet. In penetrating this again and again with the auger, it was found that the loess was wholly leached but that the till beneath was rarely leached more than a few inches to $1 \frac{1 / 2}{2}$ feet. In other words, where the covering of loess on the Iowan drift is thicker the leaching of the till is less. This strongly suggests that the leaching process has but recently reached the till. The absence of any deeper color due to oxidation of the upper part of the till as compared with the color of the overlying loess is of like significance. It indicates that the Iowan till suffered but little modification by weathering before the loess was deposited upon it. There is generally at the top of the till and beneath the loess, as seen in cuts, a more or less definite line of pebbles. This is probably the residual coarse material left from the slight wind erosion and rain wash which occurred at those particular places before the till was protected by the loess.

In line with the foregoing evidences is the fact that no soil was seen between the loess and the underlying till in the area of the Iowan drift such as was observed in the Illinoian drift area in the vicinity of Wapello and Burlington. Moreover, the Iowan till, where not loess-covered, is leached to somewhat less depths than the average sections of loess in the bordering Kansan drift area. This is in harmony with the textures of the two formations. Since the loess is more porous than the till, it should show a greater depth of leaching if both are of approximately the same age.

The general conclusions from this study of the loess are those stated above-(1) that the deposition of the uppermost till of the Iowan drift area occurred but a short time prior to the accumulation of the main sheet of loess which borders and overlaps it; (2) that the Illinoian till was deposited at a time considerably before this epoch of loess deposition; and (3) that the Kansan drift was deposited considerably earlier than the Illinoian till and much earlier than the loess was formed, or in other words, this line of evidence also supports the view that the Iowan stage of glaciation was distinct from and later than either the Kansan or Illinoian stages of glaciation. ***

As compared with the Iowan drift topography the Illinoian shows considerably more erosion. In some parts of the Illinoian drift area this may be due partly to proximity to Mississippi River, which has resulted in fairly high gradients. But on the other hand, the original surface of the Illinoian drift probably was nearly flat, whereas the surface of the Iowan drift originally had gentle slopes, with inherited major drainage lines. The latter condition is thought to be as favor-

${ }^{68}$ Alden, W. C., and Leighton, M. M., Iowa Geol. Survey Ann. Rept. for 1915 , pp. 156-157, 164, 167, 170, 1917 . 
able to the development of a drainage system as the formor, if not more so; and hence the greater amount of erosion of the Illinoian drift appears to indicate a longer time of exposure.

From these various observations it is evident that the Illinoian drift has been modified much more by weathering and erosion than has the Iowan. It also appears that most of the modification of the Illinoian occurred prior to the formation of the main deposit of loess. It seems clear, therefore, that the Iowan drift is entirely distinct from and considerably jounger than the Illinoian drift. ***

The consideration of the various lines of evidence reviewed in this paper leads the writers to the conclusion stated in the introduction, that there is warrant for the continued use of Iowan drift and Iowan stage of glaciation as major subdivisions of the Pleistocene classification.

The present writer recognizes that there are certain features which seem to favor the view that the loess and the Iowan drift are of similar age, notably the slight amount of leaching of the Iowan drift where it underlies the loess and the similarity of the depth of leaching where each is a surface deposit. The thickening of the loess around the borders of some of the Iowan drift lobes, such as the North Liberty lobe near Iowa City, also suggests a close relation to the Iowan glaciation.

On the other hand, there are certain features that do not seem to fit in well with the interpretation of a close relation between the Iowan drift and the main loess deposition. As indicated by Alden and Leighton in the statement above quoted, there is generally at the top of the Iowan till and beneath the loess, as seen in cuts, a pebbly concentrate, left as a residual deposit from the wash that occurred before the till had become protected by the loess cover. Inasmuch as this pebbly concentrate is found on some very gentle slopes its development seems likely to have been a slow process, perhaps by sheet erosion, and thus not consistent with the view that the deposition of the loess closely followed the melting of the ice sheet. In the writer's opinion this concentration may have required as long a time as the development of the Sangamon soil on the Illinoian drift, and thus the Iowan drift would date back to the Illinoian stage. As already suggested, the calcareousness of till immediately underneath loess may prove to be due to recharging of the till with calcareous material by penetration of calcareous water from the loess. Furthermore, calcareous till directly below the loess is a rare feature, due to some exceptional condition. It is the writer's observation that the till in this situation is commonly leached to a depth of several feet.

\section{WISCONSIN RED DRIFT}

In the Wisconsin stage of glaciation the ice sheet showed a remarkable amount of shifting, so that certain districts in the eastern part of Minnesota were covered first by a southward movement, and later by a southeastward one, with local deflection to the northeast. (See pl. 3.) The drift laid down at the time of the southward movement into eastern Minnesota is known as the young red drift and also as the Patrician drift; that which was brought in from the northwest and overlaps the red drift to some extent is known as the young gray drift and also as the Keewatin drift.

The ice that laid down the red drift formed a prominent lobe in western Wisconsin and eastern Minnesota, lying west of the Chippewa lobe and embracing the drainage basin of the St. Croix River and much of that of the Mississippi above Hastings. The reentrant angle between the Chippewa lobe and this lobe is in Barron County, Wis.

\section{IIMIT OF WISCONSIN DRIFT}

There is a strong morainic belt, the St. Croix morainic system, which, as interpreted by the writer, is either a close successor to or includes an outlying weak morainic ridge that forms part of the border of the Wisconsin drift in western Wisconsin and southeastern Minnesota. In places this outlying moraine is combined with the main morainic belt, but it lies well outside of that belt in loops at the main valleys. In Dakota and Washington Counties, Minn., and St. Croix County, Wis., it is distinct from the main belt and lies from 2 to 8 miles outside of it, but in Barron County, Wis., it is closely combined with the main belt. Studies by the writer in 1923 on the border of the Chippewa lobe showed this weak outlying moraine to be distinct from the main belt only for short distances at the valleys of the Yellow, Wolf, Black, and Wisconsin Rivers. It is combined with the main belt at the Chippewa River.

The outlying loop in St. Croix County, Wis., lies along the east side of the Star Prairie gravel plain, from Stanton station, on the Chicago, St. Paul, Minneapolis \& Omaha Railway, southwestward past New Richmond, Boardman, and Burkhart, passing only 1 to 2 miles east of these places. It passes just west of Roberts to Glover and comes to the St. Croix Valley near the mouth of the Kinnikinnic River, in the northwest corner of Pierce County.

On the Minnesota side of the St. Croix Valley the border is at Trout Brook, 3 miles south of Afton. It runs northward over limestone hills to a point about a mile west of Afton, where it turns abruptly westward, passes near Cottage Grove, and comes to the Mississippi Valley about 3 miles above Hastings. West of the Mississippi this outlying loop is covered by the outwash from the main St. Croix moraine for several miles back from the river. It has a small exposure in the midst of this outwash in a prominence a mile south of Rich Valley. It appears outside the outwash in Lakeville Township, northwest of Farmington, and is exposed as far as the western part of the 
QUATERNARY GEOLOGY OF MINNESOTA AND PARTS OF ADJACENT STATES

township, where it passes under a strong moraine of young gray drift of the Des Moines lobe. (See pl. 3.)

Weidman ${ }^{60}$ believes this outlying morainic loop of the Wisconsin drift to be markedly older than the St. Croix morainic system. He finds some differences in rock constituents, which he thinks are sufficient to warrant the separation, as well as the lack of concordance in trend.

The drift is a rather loose-textured reddish till. Its coarse rock constituents are derived largely from formations around the west end of Lake Superior. But quartzite, limestone, and rocks from other formations south of the Lake Superior Basin are well represented. It differs from the underlying old gray drift in carrying notably less material derived from the northwest and is deficient especially in the limestones from southern Manitoba. Any material from the northwest it contains was probably derived from the underlying drift.

Striae that bear southeastward have been noted on quartzite hills of eastern Barron County, Wis. Whether they pertain to the Wisconsin glaciation or to an earlier ice movement is undetermined. They are several miles inside the limits of the Wisconsin drift border, as traced by the writer. Being on the west side of the area covered by the Chippewa ice lobe, they appear out of harmony with the general direction of ice movements on that border of the lobe. If not of pre-Wisconsin age, they may mark merely a local deflection in the movement of the Chippewa ice lobe in the Wisconsin stage, due to some obstruction or induced by some depression.

On the Wisconsin side of the St. Croix Valley, south and east of Hudson, there is a high plain of sandy gravel which seems to have received a coating of outwash from the ice at the time of the deposition of the thin sheet of till under discussion. It stands a little higher than the gravel filling along the St. Croix Valley that connects at the north with the St. Croix morainic system. The deposits of gravelly material are very thick, and the deeper portions are probably of pre-Wisconsin age.

The question whether an area of this thin marginal part of the red drift is exposed in central Minnesota is not fully answered. The district outside the St. Croix morainic system, in Todd, Wadena, and Cass Counties, is underlain by gray drift, but in the surface portion there is an admixture of rocks that seem to have been brought in from the borders of the Lake Superior Basin. These rocks are much less abundant than in the red drift of the St. Croix morainic system. The condition here found might result either from an advance of the Patrician ice into a gray-drift area

Weidman, Samuel, Geol. Soc. America Bull., vol. 24, pp. 697-698, 1913. or of Keewatin ice into a red-drift area. In either case the Patrician ice seems at some time to have extended a little beyond the St. Croix morainic system.

\section{ST. CROIX MORAINIC SYSTEM}

DISTRIBUTION

In western Wisconsin and eastern Minnesota there is a very prominent morainic system which was mapped and described by Chamberlin ${ }^{70}$ as a correlative of the great Kettle moraine of eastern Wisconsin. It is so conspicuous on the borders of the St. Croix Valley that the name St. Croix morainic system has been given to it. ${ }^{71}$ Short sections of some of its members have also been named (Stillwater, Osceola, Alden, Franconia, etc.), but these members have not been traced and correlated along the entire exposed course of the morainic system. Its width is usually several miles, and it embraces an intricate system of ridges and sharp knolls, with inclosed basins and irregular depressions. In places the knolls rise abruptly to heights of 75 to 100 feet or more above the inclosed basins.

This morainic system as interpreted by the writer connects with its correlative system of the Chippewa lobe a short distance northeast of Cumberland, in northern Barron County, Wis. It runs across the northwestern part of Barron County and the southeastern part of Polk County to Deer Park, where it doubles back northward around a great outwash plain near Star Prairie. It is reported by Weidman ${ }^{72}$ to have a prominent interlobate spur extending northward from the vicinity of Star Prairie across Polk County, as if the ice had been split into two lobesa narrow one to the east, embracing the Namakagon Valley, and a broad one to the west, which spread widely in Minnesota. From Star Prairie the border takes a southward course through western St. Croix County, Wis., along the west side of the Willow River, and comes to the St. Croix River between Stillwater, Minn., and Hudson, Wis. There was a slight protrusion of the ice into the St. Croix Valley, so that the border on the west side of the river doubles back and runs northwestward past Stillwater Junction to the north end of a gravel plain north of Lake Elmo. The moraine then turns abruptly to a southward course and follows the border of Washington and Ramsey Counties to the Mississippi River immediately below St. Paul. West of the river it covers a belt from 8 to 12 miles in width in the northwestern part of Dakota County, Minn. Near the line of Dakota and Scott Counties this morainic system is overridden by a

To Chamberlin, T. C., U. S. Geol. Survey Thlrd Ann. Rept., pp. 291402, pl. 35, 1883 .

7 Berkey, C. P., Am. Geologist, vol. 20, p. 360, 1897.

72 Personal communication. 
morainic belt of young gray drift, which crosses it from north to south. (See pl. 3.)

Although the St. Croix morainic system is concealed to some extent by the later deposit of gray drift it had considerable influence on the topography, because of its great roughness, and is traceable across northern Scott County to the Minnesota River above Shakopee, and thence northwestward from the Minnesota Valley around the west end of Lake Minnetonka. It probably continues northwestward from Lake Minnetonka across Wright County, but the later gray-drift deposits are so thick in that county as to conceal the underlying red-drift moraines completely. The St. Croix morainic system probably passes through the central to the northwestern part of Wright County, for it appears outside the limits of the young gray drift in southeastern Stearns County, opposite the northwestern part of Wright County. However, the young gray drift covers its outer or western part in southern Stearns County and northeastern Meeker County. (See pl. 3.)

There are two conspicuous moraines of red drift in southeastern Stearns County, the eastern one near the Mississippi River as far north as St. Cloud, with the Maine Prairie outwash plain on its outer or western border, and the western and earlier one west of Maine Prairie and extending from Kimball to Cold Spring. The gray drift covers the outwash of the western moraine and encroaches on its western slope.

North of the Sauk River, opposite Cold Spring, there is a very broad morainic belt running northwestward through northern Stearns County, passing between Albany and Holdingford. It separates into two moraines near the line of Stearns and Todd Counties. The outer or western one follows the county line westward to Sauk Lake and then lies on each side of the lake northward to Little Sauk. Thence it bears northeastward past the south side of the Round Prairie outwash plain and joins the eastern moraine 4 or 5 miles southeast of Long Prairie. The eastern and larger moraine runs northward through the eastern range of townships in Todd County, its eastern border being in places east and in places west of the Morrison County line. The $\mathrm{St}_{\text {, }}$ Croix morainic system is crossed by the Northern Pacific Railway between Cushing and Philbrook and there has a width of about 10 miles. It takes an eastward course across northwestern Morrison County, and turning north crosses Crow Wing River near its mouth. The main part of the morainic system is on the west side of the Mississippi River, but a few spurs on its inner border lie east of the river in the vicinity of Fort Ripley.

From the Crow Wing River the St. Croix morainic system passes west of Gull Lake in great prominence and occupies a belt 10 to 12 miles wide across Tps. 136 and 137 N., Rs. 29, 30, and 31 W., but becomes narrowed to 4 or 5 miles in T. $138 \mathrm{~N}$., R. $31 \mathrm{~W}$. It runs northward past the west side of Pine Lake nearly to Leech Lake, with an outwash plain on its west side extending as far as Chamberlin. South of Leech Lake it is overridden by a moraine of young gray drift, but contributes to the rugged morainic topography along the south side of the lake.

The part of the St. Croix morainic belt south of Leech Lake is probably a spur from its inner border rather than a moraine formed by ice fronting toward the Leech Lake Basin. This interpretation is suggested by evidence of two kinds-(1) the termination of the strongly morainic topography near the southeast border of the Leech Lake Basin and (2) the more significant fact that red drift of the Patrician type underlies the gray Keewatin drift on the borders of the Red Lakes, some 50 miles north-northwest of Leech Lake, there being exposures of this drift on the south shore of the Lower Red Lake in the vicinity of Redby. Also west of Lake of the Woods in southeastern Manitoba there are red-drift moraines overridden by the Keewatin ice which appear to have been formed by a westward (Patrician) ice movement. The westward movement also extended about to Lake Winnipeg. It is thought that the red drift may contribute materially to the prominence of the broad morainic belt that runs westward from Leech Lake, though the surface portion of this morainic belt consists of gray Keewatin drift.

\section{MORAINIC TOPOGRAPHY}

The topography of the St. Croix morainic system is well shown on the topographic map of the St. Paul quadrangle, in the part lying west and south of the Mississippi River. Basins as well as knolls are very conspicuous. In places three 20 -foot depression contours are required to show the depth of a basin, and some of the knolls take five or more 20-foot contours. The strong expression is found in the entire length of the exposed portion of the morainic system in Minnesota, in Washington, Ramsey, Dakota, Stearns, Morrison, Todd, Crow Wing, and Cass Counties. Even where it was overridden by a later sheet of gray drift from Aitkin County northward through Itasca County, it was so rugged that it is still easily traceable.

\section{STRUCTURE AND CONSTITUTION OF THE DRIFT}

The drift of the St. Croix morainic system is exceptionally stony throughout the exposed portion, and this character seems to be maintained in the overridden portions. Cobblestones and pebbles, as well as boulders, abound on the surface, and the till is thickly set with them. The matrix is generally so loose tex- 
tured that water penetrates it quickly, and there are few surface drainage lines, for a great part of the rainfall is absorbed. Many of the basins never fill with water high enough to overflow their rims. This morainic system of red drift, although older than the morainic systems and ground moraine of the young gray drift of Minnesota, has not developed so complete a system of drainage as is generally found on the gray drift. The explanation is found in the compactress of the clay of the gray drift, which causes a larger amount of water to remain on the surface. This is gathered into streams or runs into the basins. The basins are filled to overflowing and thus have developed outlets into drainage lines. In a few places the red drift is clayey, but the clay is not so compact as that ordinarily found in the gray drift.

Large areas in the morainic system in Stearns, Todd, Crow Wing, and Cass Counties, Minn., are still covered with forest and are sparsely settled. In Washington, Ramsey, and Dakota Counties, because of the nearness to St. Paul, the land is largely cleared and cultivated, even where the steepness of the hillsides makes it difficult to work. The part in Wisconsin is fully half in forest and sparsely settled.

\section{OUTWASH FROM ST. CROIX MORAINIC SYSTEM}

There was vigorous outwash from the St. Croix morainic system into St. Croix Valley, which has had a filling more than 200 feet in depth. This filling is well exposed along the Chicago \& Northwestern Railway where it rises from the St. Croix River to Stillwater Junction, opposite Hudson, Wis., and seems fresh enough from top to bottom to be of Wisconsin age. The deposit is very sandy, with thin layers of pebbly or cobbly material separating beds of coarse sand. This outwash heads below Stillwater, at the place where the morainic system crosses the St. Croix Valley, and is continued down the valley to its mouth. There is a narrow strip of outwash northeast of Hudson, just outside the morainic system, extending past New Richmond, Wis. It is traversed by the Willow River from New Richmond to the St. Croix Valley. North of New Richmond is a wider outwash plain, known as Star Prairie, which stands outside the interlobate spur between the main St. Croix lobe and a small sublobe developed on its eastern side. It seems to have received outwash from the sublobe as well as the main lobe. This prairie and much of the outwash strip from New Richmond to Hudson has been long under cultivation, though the soil is in places very sandy. The freedom from boulders and the level surface have rendered the opening of farms relatively easy.

Outwash on the upland between the St. Croix and Mississippi Valleys in the vicinity of Lake Elmo,
Minn., fills a recess in the moraine border, noted in the above description.

The outwash into the Mississippi Valley and westward along the ice border to the gray-drift morainic belt was very vigorous, the valley and district to the west being filled to a height of more than 250 feet above the river, or to 940 to 960 feet above sea level. A considerable part of this filling occurred in Wisconsin time. The strip of outwash is several miles in width. It is traversed by channels which appear to have been cut by streams flowing from the ice border while it was still at the morainic belt. They are about 40 feet deep and half a mile or more in width. One of these channels leaves the border of the morainic belt at Crystal Lake and leads southeastward to Farmington. It is there joined by a similar valley coming in from the west, and their combined drainage went down the Vermilion Valley to the Mississippi. These valleys carry little or no outwash from the gray drift, their beds as well as the bordering bluffs being made up of the kind of rocks found in the red-drift moraines and lacking the limestones and other rocks that were incorporated in the gray drift. This seems remarkable in view of the fact that the gray-drift morainic belt is built across the northwest end of the one leading from Crystal Lake. It is also built across the valley west from Farmington.

As the ice border melted back glacial drainage was extended up the Mississippi, and this drainage cut a channel through the outwash plain outside of the moraine similar to the channels just noted. There is several square miles of outwash in the western part of St. Paul which stands only 900 to 920 feet above sea level, or a little lower than that outside the morainic system. The discharge from this outwash tract went down the Mississippi through the channel just noted. Its limits are indicated on the areal-geology map of the St. Paul quadrangle in the Minneapolis-St. Paul folio of the Geologic Atlas. This outwash tract in St. Paul has coarse cobbly material over much of its surface. It is somewhat more undulating than the ordinary outwash plain, and the material seems to be less well sorted. It may have been formed to some extent beneath the edge of the ice sheet.

In the overridden portion of the St. Croix morainic system, on the border of the Minnesota Valley, outcrops of the outwash from the red drift are found under the gray drift as far up as the vicinity of Jordan. They are very conspicuous near Chaska and Carver. The red color of the outwash is strikingly in contrast with the gray, yellow, and brown colors of the gray-drift deposits that overlie it.

The outwash from the part of the morainic system in Stearns and Todd Counties is concealed by the gray drift to a large extent, and banks cut by the streams 
are rarely deep enough to reach it, but on the border of the Crow Wing River, in Morrison and Cass Counties, the outwash plains both south and north of the river are well exposed. The outwash, however, extends only a short distance beyond the morainic border, for the ponded waters of glacial Lake Wadena stood west or outside of the ice front in the Crow Wing drainage basin. The outwash plains were built up at the edge of the ice to the level of the lake. The topographic map of the Pillager quadrangle shows these features clearly and indicates that the level of the lake was near the 1,350-foot contour. There is extensive outwash for several miles north from the Crow Wing River in Cass County, but farther north the district outside the morainic system carries very little outwash, except in the vicinity of Chamberlin, in southeastern Hubbard County, where gravelly and cobbly outwash covers an area of several square miles.

\section{GLACIAL LAIKE WADENA}

The blocking of the eastward-flowing Crow Wing River by the Patrician ice at the time of the development of the St. Croix morainic system gave rise to a glacial lake of considerable extent in this drainage basin. As it covered a large part of Wadena County, Minn., it has been named Lake Wadena. The height to which the waters were ponded was determined by the altitude of the lowest pass on the border of the Crow Wing drainage basin outside the St. Croix morainic system. There was such a pass south of Long Prairie at about 1,350 feet above sea level, and the discharge from the lake seems to have been southward from that pass. The outlet probably had a course not far outside the border of the St. Croix morainic system to the Mississippi Valley in Dakota County, Minn. Its entire course as far down as the line of Scott and Dakota Counties, however, was subsequently covered by the Keewatin ice, and its valley was so completely filled by the gray Keewatin drift that the course is effectually concealed.

The outwash gravel plains outside the St. Croix morainic system in the vicinity of the Crow Wing River are shown by the topographic map of the Pillager quadrangle to be about 1,350 feet above sea level, or at practically the same altitude as the pass near Long Prairie and about 130 feet above the low plain bordering the Crow Wing River. There is a very abrupt drop to the 1,220-foot contour at the southwest border of the gravel outwash north of the river near Pillager. The river here traverses a plain about 4 miles wide standing between 1,200 and 1,220 feet. This plain does not seem to have been reduced in level by erosion, for there are low extensions from it northward among the knolls north of the river into places plainly out of reach of the river erosion. The plain seems to mark the lowest part of the bed of Lake Wadena and to show that the lake had a maximum depth of 130 feet. The plain rises gradually westward across the old lake bed, indicating a shallower depth of the lake in that direction. Only a few square miles of the lake bed in Wadena County stands below 1,300 feet.

The district covered by Lake Wadena seems to have experienced considerable northward differential uplift, if the altitude of the border of the outwash from the St. Croix morainic system in Hubbard County may be taken as an index. The outwash there stands 1,450 to 1,470 feet above sea level, and the swampy plains bordering it at about 1,400 feet. There is an abrupt drop of 35 feet on the western border of the outwash directly west of Chamberlin, at what is thought to be the border of Lake Wadena; if it is, the lake there covered ground now standing about 1,435 feet above sea level. Chamberlin is about 40 miles north of Pillager, where the lake appears to have covered ground only to 1,350 feet. There is thus a suggestion of a differential uplift of about 2 feet to the mile in this interval. Such a rate of uplift to the north of Pillager would imply some difference in the level at Pillager and that of the head of the outlet near Long Prairie, but there appears to be none. The amount of differential uplift is thus still in a state of uncertainty, depending on the limits of Lake Wadena at the north.

The greater part of the area covered by Lake Wadena is a plain of sandy gravel that slopes to the south and east in the direction taken by the Crow Wing River. It is improbable that this material was laid down as a lake deposit, and the date and method of deposition are still unsettled. There is a strip of gray drift between the St. Croix morainic system and this plain of sandy gravel, in which limestone fragments are much more abundant than in the red drift of the morainic system. This gray drift shows a considerable number of rudely parallel northeasterly ridges, separated by shallow troughlike swales that are poorly drained. These features suggest the invasion of Keewatin ice in Wisconsin time, but perhaps the drift is pre-Wisconsin. It seems less weathered and indurated than the Kansan drift, and possibly it dates from the Iowan stage of glaciation. Similar northeastwardtrending ridges on part of the west edge of the area covered by Lake Wadena carry a drift that seems of an age between that of the Wisconsin and Kansan drifts. But the greater part of the west edge of the Lake Wadena area was covered by Keewatin ice in the Wisconsin stage, and the shore features were obliterated. This subject is more fully treated in the discussion of the drift of Wisconsin age brought in by the Keewatin ice (pp. 62-63). 
The eastern limit of Lake Wadena seems to have been along the border of the St. Croix morainic system, but definite shore features have not yet been traced on the morainic knolls, though it is not improbable that critical study may disclose them.

\section{FEATURES ON INNER BORDER OF ST. CROIX MORAINIC} SYSTEM

The writer has given very little attention to the district inside or north of the St. Croix morainic system in Wisconsin, as that district has been under investigation by Samuel Weidman, for the Wisconsin Geological Survey. The moraines in the interlobate spur in Polk County and southern Burnett County extend on the west about to the edge of the young gray drift of the Grantsburg sublobe and are overlapped to some extent in the vicinity of St. Croix by the gray drift..$^{73}$

In Washington, Ramsey, and Dakota Counties, Minn., the St. Croix morainic system extends westward to the young gray drift and in places passes under its edge. The overridden part lies between White Bear Lake and Minneapolis and runs westward to Lake Minnetonka. The topography in this overridden part is strongly morainic, as may be seen by reference to the areal-geology maps in the Minneapolis-St. Paul folio of the Geologic Atlas, yet the gray drift forms only a thin coating on most of the moraine. In places the ice that deposited the gray drift worked some of the red drift into its knolls, but in other places the knolls were formed as part of the red-drift moraine and were simply coated with the gray drift and not greatly modified by this later ice advance.

There is an extensive till plain east of the St. Croix morainic system in northeastern Stearns County and western Morrison County, west of the Mississippi River, and in northern Morrison County and southern Crow Wing County, east of the river. Its surface is gently undulating and thus is strikingly in contrast with the rugged moraine adjacent to it. The till has a rather loose-textured clayey to sandy matrix and contains numerous small stones. The surface is usually thickly strewn with boulders, which are in places a serious drawback to the cultivation of the land. The soil yields good returns in pastures and meadows. Already many dairy farms are opened on this plain on both sides of the river.

Eskers.-Eskers are found on this till plain in Morrison County both east and west of the Mississippi. They all trend west-northwest, somewhat directly toward the inner border of the morainic system. The longest one is about 6 miles from end to end. It starts at the west bluff of the Mississippi about 4 miles north of Little Falls and runs to a point about 3 miles south

\footnotetext{
${ }^{73}$ Chamberlin, R. T., Jour. Geology, vol. 13, pp. 251-253, 1905.
}

of Randall. The Northern Pacific Railway crosses it about 4 miles from Little Falls and has opened a large gravel pit in it for railroad ballast. The esker appears to be composed largely of gravel suitable for road metal. It ranges in height from 10 feet or less to fully 40 feet and is everywhere narrow and steep sided.

About 6 miles farther north there is a short esker west of the Mississippi, which extends from the river bluff westward into the edge of the morainic system, the length being about 2 miles. It is about 30 feet in lieight and is very steep sided. The material seems to be largely gravel and may be of suitable grade for road ballast.

The main esker east of the Mississippi comes to the east bluff of the river about 3 miles below Fort Ripley. It is about 5 miles in length and is a narrow, steep ridge 10 to 40 feet in height. As in those west of the river, a large part of the material seems suitable for road use. About 2 miles south of this esker is a shorter one, less than 1 mile in length, whose west end is at the east bluff of the Mississippi River. It is about like the longer one in character of material and in its variation in height.

During the development of these eskers there was probably little or no movement in this part of the ice sheet.

Sandy outwash plains.-There are extensive plains of sandy gravel in Cass and Crow Wing Counties east cf the St. Croix morainic system, and a narrower strip runs down the Mississippi Valley. Here and there are knolls or groups of knolls of boulder clay scattered through these plains. These features as well as the sandy plains seem to have been developed in the course of the recession of the ice border eastward across the area.

Dune sand.--Sand has drifted to some extent from the Mississippi Valley eastward over the upland bordering the valley, coating knolls as well as level tracts to a depth of several feet. There is also west of Brainerd a plain several miles across in which the sand is nearly free from pebbles. The slight amount of pebbly material in it suggests wind deposition rather than outwash material, but whether it was deposited by water or by wind is not clear. Where the sand is dry it is now being shifted to a slight degree by the wind.

Striae.-A few exposures of glacial striae have been Inoted inside the area bordered by the St. Croix morainic system. Some of them seem to be the product of a pre-Wisconsin ice movement that laid down the old gray drift, but others seem to be of the age of the Wisconsin red drift. Thus at Randall, in Morrison County, an older set of striae bears eastward and is probably of pre-Wisconsin age, and a later set bears 
west-northwestward toward the St. Croix morainic system and appears to be correlative with it. In St. Paul the striae that are apparently to be correlated with the red drift bear S. $10^{\circ}-14^{\circ}$ E., and in Minneapolis striae of this age bear S. $2^{\circ}-4^{\circ} \mathrm{E}$. Striae in the vicinity of Taylors Falls which bear S. $63^{\circ}-80^{\circ} \mathrm{E}$. are referred to the time of Wisconsin red-drift deposition, but those bearing $\mathrm{S} .40^{\circ}-50^{\circ} \mathrm{E}$. are referred to a preWisconsin ice movement. At Hinckley striae with southward bearing seem to be correlatable with the Wisconsin red drift. In eastern Pine County, Minn., along the Minneapolis, St. Paul \& Sault Ste. Marie Railway, there are several exposures of striae bearing about S. $10^{\circ} \mathrm{W}$. that apparently may be correlated with the red drift. The examples cited thus serve to show a range from a few degrees north of west on the west side of the ice lobe to a southerly bearing near the axis and to an easterly or southeasterly bearing on the east side.

\section{WEAK MORAINES BETWEEN ST. CROIX AND MILIE LACS MORAINIC SYSTEMS}

The area between the St. Croix and Mille Lacs morainic systems embraces southeastern Morrison, southern Mille Lacs, Benton, northern Sherburne, northern Isanti, Kanabec, and Pine Counties, Minn. It is largely till plain or gently undulating ground moraine, with a rather stony, loose-textured reddish till. Southeast of this area is one of gray drift laid down by the Grantsburg sublobe, which extends to the inner border of the St. Croix morainic system in Burnett and Polk Counties, Wis., and Washington and Ramsey Counties, Minn. This gray drift rests upon red drift of Wisconsin age, a continuation of that in the area under consideration.

There are slender and relatively weak moraines of red drift that lie in part outside and in part beneath the gray drift of the Grantsburg sublobe. One, the Beroun moraine, lies entirely outside the limits of the gray drift. The tracing of these moraines has been largely the work of F. W. Sardeson, the writer's observations being confined mainly to the part in Pine County.

Three slender morainic ridges have been noted in eastern Pine County, which trend south-southwest and die out at the south in a gravel plain bordering the St. Croix Valley. They control the courses of drainage of some of the northern tributaries of the St. Croix River. Their relief is only 10 to 20 feet above the bordering plains and their width is generally a mile or less. They are more knolly than the bordering ground-moraine areas but are of similar character in other respects. In both the drift is stony, with a liberal number of surface boulders. Except at St. Croix River there seems to be no definite gravelly or sandy outwash connected with these moraines.

\section{GRASSTON MORAINE ${ }^{74}$}

General features.-The Grasston moraine is a slender but well-defined moraine of red drift in the southern part of Kanabec and Mille Lacs Counties, which passes under the gray drift about 3 miles southeast of Grasston, in southwestern Pine County. A moraine that is probably its continuation emerges from beneath the gray drift at Cross Lake, just north of Pine City, about 8 miles from Grasston, and runs northeastward to the gravel plain on the border of the St. Croix Valley. About 6 miles farther northeast, at the north edge of the gravel plain, two narrow morainic ridges appear. The inner or western one runs northward along or near the Sand Creek Valley and connects with the Beroun moraine about 3 miles east of Askov. The other is parallel to it, nearly 2 miles farther east, and does not make so close a connection at the north with the Beroun moraine. Each of these moraines is very slender, their combined width being scarcely a mile, so they may perhaps both be correlated with the single Grasston moraine to the southwest. That moraine is about a mile in general width where exposed northeast of Pine City and also in southern Kanabec and Mille Lacs Counties. Sardeson has furnished the following description of it:

Two miles north of the southwest corner of Pine County the moraine appears at the border of the young gray drift. It is a mile wide here and runs northwest to the Snake River at Grasston and then along the river, chiefly on its south side, to the mouth of the Groundhouse River. Its course continues 3 miles farther westward on the north side of the Groundhouse River. An abandoned river valley lies across its course there, in secs. 4 and $9, T$. 38 N., R. 24 W. West of that valley the moraine is divided; the outer part, about three-quarters of a mile wide, runs southward across secs. $17,19,30$, and 31 into Isanti County and is cut off by the morainic gray-drift border at Day, $11 / 2$ miles south of the county line. The inner part, which is a mile wide, arches northward across secs. 5 and 6, T. 38 N., R. 24 W. It then resumes its southwesterly course, fcllows the north side of the south branch of the Groundhouse River, and passes just north of the southwest corner of $\mathbf{K a}$ nabec County into Mille Lacs County. It then follows Bogus Brook to the Rum River, which crosses the moraine in secs. 21 and 22 , T. $37 \mathrm{~N}, \mathrm{R} .26 \mathrm{~W}$. It continues its southwest course across both branches of Rum River and then turns southward and is cut off abruptly by the morainic border of the young gray drift 2 miles north of the Mille Lacs and Sherburne County line in secs. 23 and 24, T. 36 N., R. 27 W.

The course of the moraine in Sherburne County is completely concealed by the young gray drift and clune sand associated with it. This moraine may be correlated with one that comes up to St. Cloud from the south along the west side of the Mississippi River, to which reference was made in the description of the St. Croix morainic system. The moraine south of St. Cloud is, however, much stronger than any part of the moraine under consideration. It lies in an out-

\footnotetext{
74 From notes by F. W. Sardeson.
} 
wash gravel plain which interrupts it for several miles directly west of St. Cloud. The continuation of the Grasston moraine is more probably found in a weak moraine that runs northward from a point near St. Cloud on the west side of the Mississippi Valley for 12 miles, to the line of Stearns and Morrison Counties. A further continuation appears on the east side of the Mississippi Valley about 4 miles southeast of Little Falls. The moraine which sets in here is well defined for 25 to 30 miles northeast, to a point where it passes under the Mille Lacs morainic system in the southeastern part of Crow Wing County. It is merged with the Beroun moraine for a few miles before it passes under the Mille Lacs morainic belt. It is 1 to 2 miles wide in its course across Morrison County. For part of its course it has a gravel plain on each side, the one east of it, along the Platte River, being extensive, but its northern part is bordered by till plains.

The moraine has for the most part a moderately rolling surface, but in a few places its knolls and ridges are sharp or steep sided. Thus along Sand Creek in Pine County the moraine, though narrow, is characterized by sharp knolls. The strip of moraine south from St. Cloud also includes many sharp knolls.

The greater part of this moraine is a loose-textured clayey till. In Pine County near the Kettle River it is composed of sandy and gravelly ridges, produced perhaps by the crumpling up of outwash material in a readvance of the ice border. The moraines near St. Cloud are very sandy. The part of the moraine east of the Mississippi in Morrison County is also in large part gravelly and sandy. The part in southern Kanabec and Mille Lacs Counties is on the whole looser textured than the neighboring part of the Beroun moraine.

Outwash depasits.-The outwash deposits are relatively inconspicuous along most of the border of this moraine and are generally made up of fine sandy gravel. On Sand Creek in Pine County a narrow belt of sandy gravel extends for several miles lengthwise of the moraine, from sec. 18, T. 44 N., R. 17 W., to sec. 8, T. 43 N., R. 18 W. Along the St. Croix River there is an extensive plain of sandy gravel that seems to have been developed in the course of the recession of the ice border from the St. Croix morainic system to the moraine under consideration. In fact, the outwash appears to have been encroached upon and roughened by the advance of the ice over it at the time this moraine was formed. It was thus reworked into gravelly ridges and knolls with a little sandy till covering. Boulders are to be seen on its surface in secs. 28,32 , and 33, T. 41 N., R. 18 W., secs. 6 and 7, T. 40 N., R. 18 W., and secs. $12,13,14$, and 23 , T. 40 N., R. 19 W. Small deposits of outwash lie along the
Snake River and its tributaries between Grasston and Mora, but much of this material is included in the description of eskers which follows. East of Grasston a sandy outwash deposit extends from the lower end of Pokegama Lake southwest to and across the Snake Valley to the place where the moraine of red drift is overridden by young gray drift. The red outwash deposits both east and west of Grasston appear to extend with a covering of gray till down to Braham. From that place outwash originally extended southwest nearly to the Elk River and thence north to Princeton. By the ice advance which brought in the gray drift it has been converted into a sandy terminal moraine and sandy ground moraine of the young gray drift. From Princeton westward for 4 miles there is red-drift outwash covered by gray drift and by dune sand, but from Rice Lake westward a surface belt of red outwash extends nearly to East St. Cloud. This outwash is bordered mainly by dune sand on the south and by red till on the north. It forms a strip about 30 miles long and 1 to 3 miles wide. It has a gentle slope lengthwise from west to east, but it heads in several places along streams that come in from the north, including Mayhew Creek, the Elk River, Rice Creek, and the St. Francis River. From the Elk River eastward these outwash deposits were largely overswept by border drainage during the deposition of the young gray drift south of them.

West of the Mississippi River from Clearwater northward there is a red-drift outwash plain which slopes southwestward. Its superficial extent is restricted by the young gray drift. It is overlain on the south by gray ground moraine and on the east by gray outwash gravel; on the north glacial river gravel and silt from the gray drift encroach upon it. The Mississippi Valley has been cut across it. This outwash is east of and younger than the strong moraine of red drift that comes up to St. Cloud from the south. That moraine has an extensive outwash plain on its outer or west border, which has been noted in connection with the St. Croix morainic system.

An area of about 75 square miles of red outwash lies in adjacent parts of Benton, Morrison, and Stearns Counties. Its north end, at Royalton, is a plain sloping westward from the Platte River to the Mississippi Valley. The whole of this outwash is rather sandy. Part of it along the Watab Valley is low and swampy.

On the Platte and Skunk Rivers in Morrison County a plain of outwash gravel occupies about 30 square miles. It consists mostly of fine gravel and sand, but the material is coarser nearest its source, at the northeast end of the plain. This deposit lies well outside the Beroun moraine but may have been brought down from the border of that moraine along the valleys of the Platte, Skunk, and Hillman Rivers. 
Contemporary drainage.-The courses of the glacial drainage lines leading away from the outwash plains are partly covered and obscured by the later glacial invasion that deposited gray drift. In the area now occupied by gray drift of the Grantsburg sublobe the main rivers followed different courses from those of the present streams. The upper St. Croix apparently did not flow by Taylors Falls into the lower valley but turned near Sunrise and crossed to the Mississippi, passing near North Branch and Anoka. There was a lake west of Grasston into which the Snake River flowed, and most probably the Snake flowed south from this lake toward Anoka. The Rum River drained southeastward from Princeton, probably into the Snake River above Anoka. At Princeton drainage from the St. Francis and from the territory east of St. Cloud appears to have joined the Rum River. Drainage from the area south of St. Cloud may have run by Clearwater south to the Crow River Valley. The plains north of St. Cloud probably drained by way of Maine Prairie to the Crow Valley. With the recession of the ice border there came a lengthening of the drainage lines and more or less shifting of their courses.

$E$ skers.-Two prominent eskers, or esker belts, are found on the till plain between the moraine just discussed and the Beroun moraine-one near Mora and the other near Foley. The Mora esker is large and complex. The west branch of this esker is about 9 miles long. It begins in a small gravelly area in sec. 2 , T. 39 N., R. 24 W., and runs on the east side of the Snake Valley 11/2 miles to Mora. There the esker turned west but has been cut off by the river where the railroad bridge now stands. The esker runs southwest to Ann River and down its valley past the west side of Ann Lake. It then follows an abandoned valley southward past Devils Lake and continues through a swamp to the south side of sec. 9, T. 38 N., R. $24 \mathrm{~W}$. Gravel deposits border the esker above and close below the point where it enters the Ann Valley. The east branch of the esker joins the other between Ann and Devils Lakes. At its north end is a somewhat undulating gravel area of about 2 square miles. On Spring Creek in sec. 18, T. 39 N., R. 24 W., it begins to be definitely ridged and eskerlike and runs first to the mouth of the valley, where it is cut off by the Snake Valley, but continues beyond it up the Ann Valley, on the north side of Fish Lake.

The Foley esker is about 8 miles long and for the greater part is a single ridge 10 to 30 feet high. Ronneby stands at its head, and the esker is north of the Great Northern Railway nearly to Foley. From that place it follows the west side of Rice Creek for several miles. In sec. 16 , T. 36 N., R. 29 W., it is crossed by the stream, and there is a gap of about a mile between it and the outwash plain to the south. Throughout its length this esker consists mainly of coarse gravel, much of which is of good grade for road use.

These eskers indicate lessening of activity following an active ice movement, noted above, that shoved outwash material into morainic ridges.

\section{BEROUN MORAINE ${ }^{75}$}

Location.-The Beroun moraine, named from a village standing on it in southern Pine County, emerges from beneath the Kerrick morainic system of the Lake Superior ice lobe in northeastern Pine County, 4 miles south of Kerrick. For about 15 miles its course is southwestward nearly parallel with the Great Northern Railway, which runs 1 to 2 miles west of its inner border. It then turns southward along the east side of the Kettle River and crosses the valley east of Hinckley, where the stream turns southeast. The moraine then swings westward toward Beroun. This village is at the inner border, the outer border being at the north end of Cross Lake. The moraine then runs westward past the north end of Polkegama Lake to the line of Pine and Kanabec Counties, Henrietta station being on it. The moraine is about 2 miles wide in Pine County and is a little narrower in Kanabec County.

Though the general course of the moraine in Kanabec County is from east to west, it meanders slightly. Thus from Henrietta it runs northwestward past Quamba to the Snake River. It there turns at a right angle and follows the valley southwestward for 4 miles. Above the mouth of the Knife River it turns northwestward again and crosses obliquely a mile up the Knife Valley. Thence it runs west to Ann River and southwest past the south end of Ann Lake into Mille Lacs County. It continues southwestward across the Rum River to the west branch of the Rum, whence it turns northwestward into the northeastern part of Benton County and northward into Morrison County. In Morrison County its course is west of north for 25 miles to Platte Lake. The width increases northward to about 2 miles at Hillman and to 3 miles or more near Platte Lake. At the east side of Platte Lake, near the line of Morrison and Crow Wing Counties, the Beroun moraine becomes merged with the Mille Lacs morainic system.

Topography.-In general the Beroun moraine has a moderately rolling surface, but in a few places it has sharp knolls and ridges. Most of these rougher parts are at valley crossings. In Mille Lacs County, to the east from the Rum River along Mike Drew Branch, the moraine consists of strong eskerlike gravelly ridges which are in a valley so deep that their tops

\footnotetext{
76 From notes by F. W. Sardeson.
} 
are mostly lower than the neighboring ground-moraine areas. The depressions between these ridges are abrupt and deep. The same old valley with the sharp morainic ridges continues down the Rum River 2 miles and then across to Chase Brook, the tops of the ridges being generally below the level of the bordering till plain.

Constitution of the drift in relation to rock outcrops.-The Beroun moraine is composed mainly of rather loose-textured clay till but shows abrupt changes to sandy till or to heavy clay. The moraine is especially sandy for about 6 miles south from the Kettle River. The rougher parts are in general very stony. Diabase boulders and blocks of red sandstone are of common occurrence in the eastern part, but granite boulders take the place of sandstone in the Festern part. There are sandstone outcrops along or near the moraine from Hinckley northeastward to sec. 13, T. 43 N., R. 19 W. One outcrop occurs on the Snake River in Kanabec County, in secs. 28 and 33, T. 41 N., R. 23 W. Keweenawan diabase is uncovered by erosion in the Kettle River where the river crosses the Beroun moraine. Granite crops out in several places west of the Snake River in Kanabec County and likewise on the Rum River and its branches in Mille Lacs County. Outcrops are very extensive outside the Beroun moraine in the vicinity of St. Cloud. Granite is exposed on Hillman Brook, on the Skunk River east of Pierz, and along the Platte Valley.

Striae.-Glacial striae are found on some of the rock exposures. At Hinckley the sandstone has striae, as reported by Upham, ${ }^{78}$ which bear due south and S. $5^{\circ} \mathrm{W}$. Striae on quartz veins in granite exposures in secs. 5 and 6, T. 41 N., R. 23 W., in Kanabec County, have a magnetic bearing S. $35^{\circ} \mathrm{W}$. A railway cut in the SE. $1 / 4$ sec. 3, T. 40 N., R. 30 W. east of Pierz, exposes glaciated surfaces of granite and gneiss under 3 to 6 feet of red till. Quartz veins show striae with magnetic bearing S. $60^{\circ} \mathrm{W}$. The striae noted thus show a southward movement in the eastern part of the ice lobe, a south-southwestward movement in the central part, and a west-southwestward movement in the western part. These striae all seem referable to the Wisconsin ice movement. In the vicinity of Sauk Rapids and Watab there are several exposures of southward-bearing striae, but these may be referable to a pre-Wisconsin ice movement. West of St. Cloud there are striae with southwesterly bearing which seem referable to the Wisconsin glaciation.

Ground moraine inside of Beroun moraine.-The area of ground moraine between the Beroun moraine and the Mille Lacs morainic system is terminated on the northeast by the Kerrick morainic system of the Superior ice lobe. It is a plain about 70 miles long

36 Upham, Warren, Minnesota Geol. Survey, vol. 2, p. 642, 1888. and 20 miles wide. Four rivers cross it from north to south-the Kettle, Snake, Knife, and Rum Rivers. Most of the plain is comparatively well drained, though there are extensive swamps in the southeastern part, around Brook Park, Mission Creek, and Beroun. The drift is a stony clayey till for the most part and is somewhat heavier in the western than in the eastern part. Around Hinckley there is overridden outwash changed to sandy ground moraine. The ground moraine lies mainly east of the Northern Pacific Railway from Hinckley southward past Mission Creek to the Beroun moraine.

\section{MILIE LACS MORAINIC SYSTEM ${ }^{7}$}

Location.-The Mille Lacs morainic system, united in a single massive moraine, curves around the west and south sides of Mille Lacs Lake. The lake occupies a basin in which lay the south end of a lobe of the Patrician ice sheet at the time when this moraine was made. Eastward from Mille Lacs Lake the morainic belt maintains a width of about 6 miles to the Willow River, where it is overlapped by the Kerrick morainic system of the Superior ice lobe.

The course of the moraine on the west side of the lobe is somewhat irregular. The northwestern part of Mille Lacs Lake projects into the moraine about 2 miles, thus reducing its width locally to 4 miles, but to the north the moraine broadens. Between Mille Lacs Lake and the Mississippi River the moraine divides and reunites, and each part makes a reentrant angle. The outer part runs north between Bay and Nokay Lakes. Thence it turns first westward between Nokay and Lookout Lakes to Brainerd and then northward along the east side of the Mississippi River to the mouth of Pine River. Some of its knolls lie west of the Mississippi.

The inner part of the moraine turns northeast from the west side of Mille Lacs Lake, between Bay and Farm Island Lakes, to Hanging Kettle Lake and Rossburg. It there bends sharply back and runs nearly west past Aitkin and between Serpent and Rabbit Lakes, where it unites with the outer part and turns with it north across the Mississippi Valley.

North of the Mississippi the united moraine is at first restricted to 3 miles in width by outwash deposits along the Pine River, but it soon widens to 5 or 6 miles. Southeast of Emily the inner part of the moraine takes an eastward turn and runs to Esquagamah and Waukenabo Lakes, in western Aitkin County, and then turns northward to Swatara. This inner moraine is 2 to 4 miles wide. In the outer part of the moraine between Emily and Crooked Lake there is a gap of about 3 miles, with ordinary ground-moraine topography. A strong moraine sets in beyond the gap and

" From notes by F. W. Sardeson. 
runs northeastward from Crooked Lake past Mae to Shovel Lake. West of Crooked Lake is another moraine, less definitely referable to the Mille Lacs system, that runs northward past Washburn and Thunder Lakes to Big Rice Lake. Northeast of Big Rice Lake, Shovel Lake, and Swatara the young gray drift forms a veneer over the moraines of red drift. The Mille Lacs morainic system seems to be continued beneath the gray drift from northwestern Aitkin County northward across the Mississippi River into northern Itasca County, as indicated on Plate 3.

Topography.-The Mille Lacs morainic belt is very prominent in certain parts and is mostly well defined in comparison with the ground moraine. West from the Kettle River it consists at first of a series of strong parallel ridges, with either swamps or sandy flats between them. One of these ridges, which is crossed by the Northern Pacific Railway about a mile north of Finlayson, is practically continuous from the Kettle River to the Snake River. West of the Pine Lakes, near the boundary of Pine and Aitkin Counties, the moraine consists more of knolls than of ridges, and that is its general character farther west and north. West of Mille Lacs Lake the moraine is very rugged, and that condition prevails to Hanging Kettle Lake and thence northwest to Rabbit Lake. North of the Mississippi the moraine is generally strong and in part high and rugged. The features of the morainic system from the west side of Mille Lacs Lake northward to the northeastern part of Crow Wing County are well shown on the Deerwood, Cuyuna, and Brainerd topographic maps. In this part lakes and swampy depressions are very numerous. Lakes are less numerous from Mille Lacs Lake eastward, but swampy depressions abound.

Character of the drift.-East from the Kettle River to the locality where the morainic belt is overridden by the Kerrick morainic system the drift is gravelly and loose textured and seems to be reworked outwash material. There are only a few prominent knolls in this part, and these consist of sandy till. West of the Kettle River the moraine is complex. A belt of clayey till 2 miles wide at the Kettle River forms the outer part of the morainic strip from secs. 3 and 10 to sec. 18, T. $43 \mathrm{~N}$., R. $20 \mathrm{~W}$. There is a small area of outwash in sec. 18, near Finlayson. The clayey ridge is narrowed to about a mile from Finlayson westward into the edge of Aitkin County and then becomes wider again. Another belt of clay till about half a mile wide lies in the midst of the morainic system from the Kettle River westward to a lake in sec. 21, T. 43 N., R. 21 W. Between these clay belts is a strip of sandy till 2 or 3 miles in width. This includes much swamp land. The inner half of the moraine, north of the Pine River in Pine County, is mainly clayey till but includes some sandy till. Thus a sandy strip half a mile wide runs from the Kettle River in sec. 3 to Pine River in sec. 19, T. 44 N., R. 20 W. Another runs from sec. 8, T. 44 N., R. 20 W., to sec. 33, T. 44 N., R. 21 W. A belt of outwash 2 miles wide east and northeast of the Pine Lakes includes several ridges of sandy till. This belt extends into the southeast corner of Aitkin County and has a strip of sandy till on the northwest, in secs. 24, 27, and 33 .

Along the border of Kanabec and Aitkin Counties the till of this morainic system is generally clayey. West of Mille Lacs Lake and northward to the Mississippi the moraine is generally of loose texture and contains many cobblestones and small boulders. There are places, however, east of Deerwood in which a heavy clay till is found.

From the Mississippi River northeastward to the area where this morainic system passes under the sheet of young gray drift in northwestern Aitkin County it is generally very loose textured and full of cobblestones. Southeast of Emily is a tract of about 3 square miles in which the drift is a sandy gravel with rugged contours and a relief of about 100 feet above neighboring parts of the morainic system.

Rock outcrops and striae.-Rock outcrops are few within the limits of this morainic system because of the prevailing great thickness of its drift deposit. Along the outer or southern border there are some exposures of granite and other crystalline rocks in the valleys of the Snake, Knife, and Rum Rivers. Near Denham, in northwestern Pine County, on the inner border of the morainic system, there are many small outcrops distributed over secs. 2,3 , and 4, T. $44 \mathrm{~N}$., R. 21 W., and secs. $26,33,34,35$, and 36, T. 45 N., R. $21 \mathrm{~W}$. Gneiss crops out in secs. 1 and 12, T. 43 N., R. 24 W., and although clearly defined glacial striae were not noted on these rock exposures, they are rounded and smoothed by glacial action. At Denham, within the limits of the Kerrick morainic system of the Superior lobe, rock exposures under what is perhaps Patrician red drift show striae with a magnetic bearing S. $62^{\circ} \mathrm{W}$.

Outwash.-Extensive deposits of outwash were made on both the east and the west sides of the ice lobe, but no considerable amount at the center or end. East or southeast of the lobe the moraine is almost displaced by outwash, on the east side of the Kettle River. This deposit was overridden by the Superior ice lobe from Moose Lake south as far as the Willow River and was disturbed by glacial action and augmented somewhat by newer outwash. From the Willow River to Rutledge there is a belt of outwash 2 miles wide and about 5 miles long, lying in the outer half of the moraine. Another area of sandy outwash about 7 miles long and 2 miles wide lies in the inner half of 
the morainic belt and extends southwest and northeast of the Pine Lakes along the Pine River. It is associated with an even larger area of sandy moraine made by the readvance of the ice sheet into outwash deposits. Areas of outwash covering less than a square mile each occur at Finlayson, in sec. $3, \mathrm{~T} .42$ N., R. 21 W., at Bloemendal, and at Red Top.

West of the lobe a strip of outwash about a mile wide extends from the inner edge of the reentrant spur of the St. Croix morainic system along the Nokaysippi Valley to Long Lake and thence to Nokay and Clearwater Lakes, where it spreads out in the reentrant of the Mille Lacs morainic system. It reaches the south end of Bay Lake, and a branch of it extends south to Dagget Brook. At Brainerd outwash gravel extends from the glacial Mississippi channel, in secs. 17,20 , and 29 , T. 45 N., R. 30 W., northeastward into the front of the morainic area at the end of the Brainerd sublobe, in secs. 3 and 11.

North of the Mississippi there is nearly continuous outwash from the western or outer border of the Mille Lacs morainic system westward to the inner edge of the St. Croix morainic system and reaching as far north as Whitefish Lake and Lake Emily. It lies mainly outside of the Mille Lacs morainic system but heads back into that system near the mouth of the Pine River on the Mississippi. Within the morainic belt there is only a small amount of outwash north of the Mississippi. One deposit covering about a square mile occurs at Mud Lake, in sec. 17, T. 37 N., R. 25 W., and other small ones occur elsewhere in the Mud Creek drainage area.

South of the Mississippi a large outwash deposit between the two parts of the Mille Lacs morainic system on the Little Rabbit River appears to be the regular successor to the Pine River area in Crow Wing County. This gravelly outwash area extends over about 20 square miles. It comes within a mile of Mississippi River and reaches from Little Rabbit and Portage Lakes to Serpent, Reno, and Lookout Lakes near Deerwood. An area of outwash and lake sands north of Mille Lacs Lake is described as a dependency of the Kimberly moraine.

Associated till plains.-A till plain interrupts the outer part of the Mille Lacs morainic system in the northeast corner of Crow Wing County and adjacent parts of Cass and Aitkin Counties, embracing an area of about 40 square miles. A part of it directly east of Outing has been cleared and tilled, but most of it is in forest. Its surface is gently undulating and the soil is a moderately stony clay loam. It is less thickly strewn with boulders, in the farms that have been cleared, than most of the bordering moraines or than a till plain northeast of Crooked Lake in southeastern Cass County. That plain where traversed by the road leading from Outing to Remer is in places literally paved with boulders. Scarcely any of it has been brought under cultivation.

Eskers.-About 2 miles south of Little Pine, near the south edge of the plain in northeastern Crow Wing County, is an esker whose features are well shown on the Cuyuna topographic map. It starts near Birchdale Lake, in the northern part of sec. 4, T. 137 N., R. 25 W., and leads westward with a somewhat winding course across sec. 5 into the northeastern part of sec. 6. It is composed of coarse gravel and cobbles, and the surface is boulder-strewn. It splits into several ridges at its west end, next to the moraine. It is very steep sided for its entire length. In places it has a narrow swamp on each side. The bordering land is made up of gently undulating till with a few surface boulders.

Plain between Mille Lacs morainic systemi and Kimberly moraine.-The intermorainic plain between the Mille Lacs morainic system and the Kimberly moraine has been greatly restricted by later ice movements and the deposition both of the Superior red drift and the young gray drift. On the east side, where the Kerrick morainic belt crosses the Mille Lacs morainic belt, an irregular piece of ground moraine lies between them. The extreme east end of this piece is 9 miles east of the Pine and Aitkin County line. The plain widens westward to 6 miles at the county boundary, but is only 3 miles wide 6 miles farther west, in Aitkin County. It widens to about 16 miles at the east side of Mille Lacs Lake.

The east end of the plain is a relatively high tract of clayey till. It is also high south and southwest of Denham, and the clay swells are interspersed with small rock outcrops, from which boulder trains extend southwestward in the direction of ice movement. The surface becomes lower and more swampy westward into Aitkin County. In T. 44 N., R. 22 W., the ground moraine is nearly all covered with swamp muck, and the same condition continues to the Snake River. West of the Snake River the plain spreads widely, westward to the shore of Mille Lacs Lake and northward to the Kimberly moraine. This wide part of the plain is mainly clayey till with isolated groups of small gravelly knolls or kames. It is very swampy except near the lake, where the swamps are moderate in size.

North of Mille Lacs Lake, near Wealthwood, a few square miles of till plain lies between the lake and a plain of sandy gravel to the north and east. It is all low, rather wet land, and much of it has been covered by the lake. It includes a somewhat higher tract in secs. 16 to 21 , T. 45 N., R. $26 \mathrm{~W}$. The southern parts of secs. 19 and 20 were at one time submerged and are cut by low shore lines and thickly strewn with boul- 
ders. The whole area appears to be clayey till, but part of it has also lake silt on its surface. Another strip of ground moraine, with red till, borders the Kimberly moraine between Kimberly and Rossburg. It is cut off at the east by the young gray drift. Some of it along the Rice River has been covered by Lake Aitkin. It is heavy clay and mostly swampy.

Two short eskers are noted here. One about half a mile long lies in sec. 8, T. 43 N., R. 24 W., and runs southwestward to a small lake. Another runs along the south side of secs. 33 and 34, T. 45 N., R. 24 W., and into sec. 5, T. 44 N., R. 24 W. It is strongest in sec. 34 .

Outlets of Mille Lacs Lake.-Mille Lacs Lake appears to have had at its highest stage a discharge by three outlets, one north by the Mud River, a second southeast by the Knife River, and a third southward into the Rum River. The lowering of the lake surface by the deepening of the Rum River Valley appears to have stopped the flow by the Mud River, although the low land tributary to that stream is also shut off by a rampart beach 15 feet above the present lake, along which the wagon road now runs from. Nichols to Wealthwood. Similarly the Knife River has had the discharge from Mille Lacs Lake cut off by beaches or ice ramparts across the outlet at Wahkon, but drainage from land a few rods back of the lake shore in secs. 9 and 10, T. 42 N., R. 25 W., flows to the head of the Knife River. Ogechie Lake is separated now, too, by raised sandy beaches of Mille Lacs Lake, but across that barrier the one necessary outlet from the lake is maintained to Ogechie Lake and thence to the Rum River.

\section{KIMBERLY MORAINE}

The Kimberly moraine was nearly all overridden by later ice movements. It is cut off by the Wright moraine of the Superior ice lobe on the east and covered by ground moraine of the young gray drift on the north. The normal moraine, seen at Kimberly, extends from Rock Lake in sec. 21, T. 48 N., R. 24 W., to Rabbit Lake, in sec. 17, T. 46 N., R. 25 W., a distance of about 13 miles, and is 2 to 3 miles wide. Southeast of Rabbit Lake it is displaced by outwash, and west of this lake it is banked against the reentrant of the Mille Lacs morainic system. Its continuation probably lies beneath the moraines of the Superior lobe eastward from T. 45 N., R. 24 W.

From the north end of the exposed part at Rock Lake northward the moraine is covered by the young gray drift. It is sufficiently prominent, however, around Sandy Lake and northward along the east side of the Mississippi River to Jacobson to be easily traced. Some of its ridges and knolls are 50 feet or more above the bordering plains and have only a thin cover of the young gray drift. For about 5 miles north from Jacobson there is a sandy plain. The moraine then reappears in exceptional strength, directly west of the Swan River, and runs northward along and mainly west of the Great Northern Railway (Swan River and Hibbing branch) to the Mesabi iron range at Nashwauk, beyond which it is less definitely preserved. It is spread out in places to a width of 5 or 6 miles and its highest part, in the vicinity of Acropolis and for several miles to the north, is fully 100 feet above the bordering plains. The young gray drift scarcely forms a continuous coating on this prominent part of the moraine.

This moraine in both its exposed and its overridden portions contains gravelly ridges and knolls and a large amount of loose-textured drift. In places, however, the till is a heavy clay. Its red color and its stony character distinguish it from the overlying gray drift, which contains relatively little coarse material. Where it is overridden by the Superior red drift there is but little contrast in color or in stoniness. The Superior drift, however, is of a somewhat brighter red and includes more clayey material than is commonly found in the red drift of the Patrician ice sheet.

There is an extensive outwash plain of sandy gravel north of Mille Lacs Lake, which rises toward the northeast into the edge of the Kimberly moraine, between Rabbit and Clear Lakes. At the head of the deposit, in secs. $20,21,28$, and 29 , T. 46 N., R. 25 W., there is a succession of gravel banks trending southwest which are separated by shallow drainage channels. The gravel is coarse and contains numerous cobblestones. For the greater part the deposit changes gradually toward the west and south to fine gravel or even sand. This outwash covers more than 50 square miles. The northern part is high and relatively dry; the western and southern parts are mostly swampy. The bottoms of the swamps appear to have some lake silt in addition to the sandy outwash, as they are below a former high level of Mille Lacs Lake, 10 feet or more above the present level. At that level the lake flooded into Round and Borden Lakes and extended an arm into Ogechie Lake.

\section{MORAINES OF THE SUPERIOR ICE LOBE IN MINNESOTA AND CORRELATIVE PATRICIAN MORAINES}

The young red drift deposited by the Patrician part of the Laurentide ice sheet, so far as already described in this report, falls in what has recently become known as the middle Wisconsin substage. This substage is set off from a later one known as the late Wisconsin by a marked recession of the ice front, followed by a distinct readvance, and also by considerable shifting in the direction of ice movement. The later moraines thus have a different trend from the earlier ones Parts of each of the moraines from the St. Croix to 
QUATERNARY GEOLOGY OF MINNESOTA AND PARTS OF ADJACENT STATES

the Kimberly are now covered by drift of late Wisconsin age. The St. Croix morainic system has thus been partly covered by drift laid down by the Keewatin part of the Laurentide ice sheet. The Mille Lacs morainic system and also the Kimberly moraine pass northward beneath the Keewatin drift and eastward beneath drift of the Superior ice lobe, which it is thought pertains to the Labrador part of the Laurentide ice sheet. In middle Wisconsin time the $\mathrm{Pa}$ trician ice movement extended southward across the western part of the Lake Superior Basin into Wisconsin, but in late Wisconsin time it appears to have extended only a few miles beyond the Canadian boundary into northeastern Minnesota. The morainic system marking the limit of the Patrician readvance in late Wisconsin time, as shown in Plate 3, connects in eastern Lake County, Minn., with the Highland morainic system of the Superior ice lobe. It passes westward across central Lake and St. Louis Counties and, as indicated below (p. 64), disappears under the edge of the Keewatin gray drift.

A description of the moraines of the Superior ice lobe in Minnesota has been recently published, ${ }^{78}$ and only a brief summary of the features of the Minnesota portion is given here.

\section{DISTRIBUTION}

By reference to Plate 3 it will be seen that no less than six distinct moraines were developed on the northwest border of the Superior lobe in Carlton County and adjacent parts of St. Louis and Aitkin Counties, Minn., named in order of development the Wright, Cromwell, Draco, Cloquet, Thomson, and Fond du Lac moraines. Five of these are combined into a single prominent morainic system, the Highland, in southeastern St. Louis and Lake Counties, the Fond du Lac moraine alone remaining distinct. On the south side of the ice lobe, in northern Pine County and southern Carlton County, these five moraines are combined into two prominent morainic belts, the Kerrick and Nickerson moraines, and the Fond du Lac moraine is banked against the Nickerson in southeastern Carlton County and eastward into Wisconsin. The Kerrick moraine seems to be the equivalent of the Wright and Cromwell moraines, and the Nickerson the equivalent of the Draco, Cloquet, and Thomson moraines. In Cook County, the northeasternmost county of Minnesota, two moraines were mapped that are younger than the Highland morainic system. The cuter one is regarded as a probable equivalent of the Fond du Lac moraine; the inner one was probably developed somewhat later. The Fond du Lac moraine, at the end of the ice lobe, in Carlton County,

\footnotetext{
${ }^{78}$ Leverett, Frank, Moraines and shore lines of the Lake Superlor
Basin: U. S. Geol. Survey Prof. Paper 154, pp. 1-72, 1929.
}

was laid down in ponded waters of glacial Lake Nemadji and was later covered by the waters of glacial Lake Duluth.

\section{GENERAL CHARACTERISTICS}

The Kerrick morainic belt consists mostly of small knolls, 5 to 20 feet in height, rather closely aggregated, though in places, as near Belden, it includes wide swamps. Where this belt overrides the Mille Lacs morainic system its knolls are less conspicuous than those of the earlier one, and its general relief above outlying districts is slight. The till is generally loose textured but in places consists of heary clay. The color is a brighter red than that of the Patrician drift. The pebbles consist largely of sandstone from the borders of the Lake Superior Basin but include also some of basic volcanic rocks.

In the Wright and Cromwell moraines the knolls are generally more scattered than in the Kerrick moraine. They run through a region of peat bogs and consist of groups of knolls or of short ridges for stretches of 1 to 3 miles, separated by wide swamps. As these bogs have a peaty filling of 5 to 20 feet, low knolls may be completely overgrown and concealed under them.

The Nickerson moraine presents a knolly and ridged surface of moderate strength. As in the Kerrick moraine, its knolls are generally less prominent than those of outlying and underlying parts of the Mille Lacs moraine. Its rock constituents are similar to those of the Kerrick belt. The Draco, Cloquet, and Thomson moraines, which are correlated with the Nickerson, are in places somewhat more diffuse or interrupted more largely by swamps but are on the whole well defined. In places they are interrupted by outwash and glacial drainage channels, as indicated below.

The Highland morainic system is separable into two distinct belts for a few miles directly back of Duluth, with an inclosed till plain of about 50 square miles surrounding Wild Rice Lake. But from the east side of Duluth northeastward for more than 60 miles it is a single massive morainic belt from 4 to 6 miles in general width but in places reaching a width of 7 or 8 miles. Back of Duluth its inner border is only 1 to 2 miles from the shore of Lake Superior, and it stands 600 to 900 feet above the lake. Thence it bears inland and is 9 to 12 miles from the lake in Lake County. It increases gradually in altitude toward the northeast and reaches about 2,000 feet above sea level, or 1,400 feet above Lake Superior, in eastern Lake County. It there meets a correlative morainic system formed by the southward-moving (Patrician) ice, and its great prominence is due in some degree to heaping up of drift at this junction. Some of the drift ridges 
there are 100 feet or more in height. The Highland morainic belt is prevailingly of the strong knob and kettle type, with knobs and ridges of drift rising 25 to 75 feet or more above inclosed depressions. The lakes within this morainic belt are not so large or so numerous as those among the rock hills and ridges farther north, the largest lake being only about 2 square miles in extent. The drift in this morainic belt is generally very loose textured and contains many cobblestones and small boulders. There is, however, enough fine material in the matrix to give it a loamy character. The Keewenawan diabase of Beaver Bay, which forms a notable constituent of the drift, contributes loamy material on weathering.

The Fond du Lac moraine in Carlton County, which was deposited in water, as indicated by railroad cuts and ravines in its prominent part southwest of Fond du Lac, contains a large amount of fine sand and pebbleless clay capped by a few feet of clayey till. The part north of Lake Superior stands above the level of glacial Lake Duluth and is composed of stony till.

\section{OUTWASH AND GLACIAL DRAINAGE FROM THE SUPERIOR} ICE IOBE

Gravelly outwash is conspicuous on most of the outer border of the Highland morainic belt in Lake and St. Louis Counties. It starts a few miles northeast of the head of the Cloquet River, but the discharge from it went down the Cloquet Valley. The breadth of the outwash ranges from less than a mile to 4 or 5 miles. It came in at numerous discharge points, where it is usually made up of coarse cobbly material. In places the ice seems to have readvanced into its outwash and introduced bouldery material, as between Burnett and Brookston and south of Brookston. The outwash at Brookston was carried up the St. Louis Valley a few miles from the mouth of the Cloquet River, for it was prevented from turning down St. Louis Valley by the presence of the Superior ice lobe below the mouth of the Cloquet.

Outwash was relatively scanty on the border of the Wright moraine in southwestern St. Louis County and northwestern Carlton County, and glacial drainage appears to have followed narrow passages among the outlying ridges. There was more conspicuous outwash from the border of the Cromwell moraine. For several miles southwest from Cromwell on the south side of the Northern Pacific Railway it is interbedded more or less with morainic material.

At the end of the Superior lobe outwash takes the place of the Wright moraine for a space of 6 miles and spreads over a width of 2 to 4 miles. It consists of a fine sandy gravel. The outwash on the south side of the lobe, in Pine County, is so closely associated with outwash from the Beroun and Mille Lacs moraines of the Patrician ice that it can be distinguished only with difficulty. In places it fills in spaces between the Patrician knolls and ridges, and in such situations it is rather fine sandy gravel.

There is an outwash plain of fine sandy gravel covering about 10 square miles on the outer border of the Nickerson morainic belt in the Willow River drainage basin. Very little outwash is present on the border of the Draco moraine, but the outwash and glacial drainage between the Draco and Cloquet moraines are very conspicuous. The outwash plains between Big Lake and Cloquet show a steplike succession toward Carlton, either from Big Lake or from Cloquet. In these steps the tread is an outwash plain or glacial drainage line, and the riser is the steep slope down to the next lower slope, marking a correlative ice border. Boulders and till are present in places on these steep slopes. The most conspicuous line of glacial drainage is the Scanlon channel, leading from Scanlon, on the St. Louis River, to Atkinson, beyond which there are two channels, an earlier one along the Northern Pacific Railway to Moose Lake and a later slightly lower channel running southwestward between the Cloquet and Thomson moraines. The Scanlon channel carried a large volume of water, draining the north side of the Superior ice lobe and perhaps also the southeast edge of the Keewatin ice, which seems to have been, at its culmination, only a short distance from the border of the Superior ice lobe. This drainage led southward from Moose Lake to the Kettle River and thence to the St. Croix River and down it to the Mississippi. The drainage from glacial Lake Nemadji also took this course from Moose Lake at the time of the development of the Thomson and Fond du Lac moraines.

\section{GLACIAL IAKES CONNECTED WITH THE SUPERIOR ICE} LOBE

The main lake connected with the Superior ice lobe is known as glacial Lake Duluth. It occupied the west end of the Lake Superior Basin and was held up by the portion of the ice lobe remaining in the eastern part of the basin high enough to outflow southward into the St. Croix Valley, tributary to Mississippi River. Small lakes antedating Lake Duluth occupied the parts of drainage basins tributary to the Lake Superior Basin that lay outside the border cf the Superior ice lobe, and two of them, glacial Lake St. Louis and glacial Lake Nemadji, were in northeastern Minnesota. There were several others on the south border of the ice lobe in Wisconsin and Michigan. 
GLACIAL LAKE ST. LOUIS

There was considerable complication of ice movements involved in the history of glacial Lake St. Louis, and it has not yet been fully cleared up. The lake area is within the limits of the part of the St. Louis River Basin that was covered by the Keewatin ice, which came in from the west. The culmination of the Keewatin ice movement was probably somewhat later than that of the Superior lobe, for moraines of Patrician ice that are correlated with the outer moraine of the Superior lobe were overridden by the Keewatin ice in the district north of the St. Louis Basin, as indicated below (p. 56). At the culmination of the Superior ice movement and prior to that of the Keewatin advance there may have been a ponding of waters in the St. Louis Basin outside the Superior lobe. But any evidence of such ponding is probably concealed beneath the deposits of Keewatin drift. The lake features on the surface of the Keewatin drift are later and are dependent upon the retreat of the Keewatin ice front. This withdrawal appears to have taken place while the Superior ice lobe was still covering the St. Louis Valley as far up as Carlton. At that time the Scanlon channel was opened, and it appears to have received a strong flow of water from the glacial Lake St. Louis.

Winchell ${ }^{79}$ applied two names to the ponded waters in the St. Louis Basin. An earlier lake, called Lake Upham, he assumed had a westward discharge, and a later one, Lake St. Louis, he interpreted to have opened the Scanlon channel. Winchell was unaware that the Keewatin ice was involved in the history of the glacial lake in the St. Louis Basin and so assigned a westward outlet for his Lake Upham into the Mississippi River.

The head of the outlet of glacial Lake St. Louis is near Mirbat, about 3 miles below Floodwood, Minn. A well-defined beach comes to this outlet from the west along the south side of the East Savanna River. Its altitude is about 1,275 feet. This is a little lower than the divide between the East Savanna and West Savanna Rivers at the place where Winchell supposed the lake had a westward discharge. A canal survey from the St. Louis River to the Mississippi shows an altitude of 1,282 feet at the divide. ${ }^{80} \mathbf{A}$ slightly lower pass across the divide is shown by the Great Northern Railway profile between Swan River station and Jacobson, the summit there being about 1.275 feet above sea level. There may be places on the divide with still lower altitude. It is probable, however, that the Keewatin ice was still covering this

\footnotetext{
To Winchell, N. H., Glacial lakes of Minnesota : Geol. Soc. America Bull., vol. 12, pp. 124-125, 1901; Geology of Minnesota, vol. 4, pls. 56, 87,1899 ; idem, vol. 6, pl. 66, 1901 .

${ }^{80} 34$ th Cong., Ist sess., B. Doc. 330, p. $13,1896$.
}

divide while the lake was forming the beach near Floodwood and discharging down the St. Louis River to Scanlon.

It has not been feasible to trace the shore of this glacial lake in the district east of the St. Louis River or indeed anywhere except for the few miles along the south side of the East Savanna River, for that is the only place on the whole circuit of the old shore where the country has been cleared and drained. The banks. of streams traversing this old lake bed show thick deposits of nearly pebbleless silt, and farms around Floodwood show the silt to be present some distance back from the streams. The silt gives place to sand toward the north, and the change seems to take place at an altitude of about 1,300 feet. The sand probably marks the shallow-water margin of the lake and the silt was laid down in the deeper water. It is probable that differential northward uplift has affected this lake basin, for it is known to have affected the bed' of glacial Lake Duluth to the east and of Lake Aitkin to the west. In that event the lake may have stood a little above the 1,300-foot contour on its northern shore.

The outlet of glacial Lake St. Louis led down the St. Louis Valley to Scanlon, and the valley seems to have carried a strong stream about one-third of a mile in width, as shown by the cobbly material on its bed, which is now a low terrace bordering the stream. After turning away from the St. Louis Valley the outlet soon crossed the present divide between the Great Lakes and the Mississippi. This crossing is near Atkinson, at an altitude of 1,170 feet, or 100 feet lower than the head of the outlet near Floodwood. A few miles farther southwest, near Barnum, the outflow cut through the glacial gravel to the underlying rock at about 1,100 feet above sea level.

Glacial Lake St. Louis may have persisted until the Superior lobe had shrunk to a position inside the Thomson moraine, and its outlet may have shifted to glacial Lake Nemadji at Wrenshall. A thick deposit of calcareous clay in the vicinity of Wrenshall may be referable to the drainage from the Keewatin ice and its calcareous drift.

\section{GLACIAL LAKE NEMADJI}

In his report on Carlton County in volume 4 of the "Geology of Minnesota," Winchell called attention to the channel that leads westward from the west end of the Lake Superior Basin to Moose Lake and thence southward through the Kettle River to the St. Croix. He applied the name Lake Nemadji to the small body of water that stood between the receding ice border and the head of this outlet, for its bed is now largely drained by the Nemadji River. The head of the outlet is about 1,070 feet above sea level. The 
width of the outlet to the east of Moose Lake is from one-sixth to one-fourth of a mile, and the channel was cut to a depth of only 10 to 20 feet. The small size of the outlet indicates that only a small volume of water passed through it and that it was in operation for a relatively brief period. It began while the Thomson moraine was being developed and continued until the Superior lobe shrank away from the Fond du Lac moraine sufficiently to permit its waters to flow eastward to the St. Croix outlet, the outlet of glacial Lake Duluth.

The area of glacial Lake Nemadji may have reached 50 square miles before its waters were shifted to the St. Croix outlet. There is a thin deposit of sand over the part of the lake bed outside the Thomson moraine, and two sandy ridges differing about 5 feet in altitude mark its northwest shore. The south shore is mainly a cut bluff along the border of the moraine. There is some sand on the lake bed between the Thomson and Fond du Lac moraines, but inside the Fond du Lac moraine the lake bed is generally a stiff clay.

\section{GLACIAL LAKE DULUTH}

Glacial Lake Duluth was for a short time called the "Western Superior Glacial Lake" but later was renamed from the city of Duluth, in which its shore lines had long been recognized as such. Its outlet to the St. Croix Valley has also been long known. The Superior ice lobe, which held up this body of water, melted back so slowly that the outlet became materially deepened before lower outlets became available and the lake waters were drawn down below its level. The outlet to the St. Croix appears to have been cut down to about 1,070 feet above sea level by a small predecessor, glacial Lake Brule, and was cut to or slightly below 1,022 feet during the life of the large lake. The uppermost strong beach stands 1,070 to 1,076 feet above sea level in the vicinity of the outlet. A lower beach stands at 1,040 to 1,044 feet, and a still lower one at 1,017 to 1,022 feet. As the floor of the outlet has a thin covering of peat and muck at its head there probably was discharge of lake waters through it while the last-named beach was forming.

The eastern limits of glacial Lake Duluth on the south side of the Lake Superior Basin appear to have been at the Huron Mountains, in northwestern Marquette County, Mich. When the ice melted away from the northern and eastern slopes of the Huron Mountains, border drainage channels were opened, and through these the waters were carried into the Lake Michigan Basin. The lake level was lowered step by step as lower and lower lines of border drainage were opened by continued recession of the ice border. The eastern limits of Lake Duluth on the north side of the Iake Superior Basin have not been determined. It is known, however, that it extended at least to the Kaministiquia River Valley back of Fort William, Canada, and it may have extended considerably farther.

Wherever the exposed part of the bed of glacial Lake Duluth has a smooth surface the prevailing soil is a heavy red clay with few pebbles. There is remarkably little sand or loose-textured material covering this clay. The clay carries some calcareous nodules, but limestone pebbles are rather rare. On hilly areas that were covered by the lake, such as the Bayfield and Keewenaw Peninsulas of the south shore and much of the north shore, the soil consists largely of stony till. The Lake Duluth beaches are everywhere formed in this stony till or in gravelly drift.

The shore lines of Lake Duluth show marked northcastward differential uplift throughout their extent. Near the west end there is a rise of about 60 feet between the altitude of the south shore line and that at Duluth, though the intervening space is only about 24 miles. The highest shore line appears to extend eastward only into southwestern Lake County, Minn., where it has an altitude of 1,165 feet. The shore lines that continue into the northeast corner of Minnesota show that the lake there covered ground that is now 1,300 feet above sea level, or 700 feet above Lake Superior. The upper limit on the Keweenaw Peninsula near Calumet, Mich., is similar, being 1,305 feet. A comparison of altitudes of beaches on the north and south shores of Lake Duluth indicates that over much of its area the direction of the line of maximum tilting is about N. $32^{\circ} \mathrm{E}$. Data bearing on this matter are given in a recent report. ${ }^{81}$

\section{LATE WISCONSIN MORAINES OF THE PATRICIAN ICE IN NORTHEASTERN MINNESOTA}

As indicated in the discussion of the Highland morainic system of the Superior ice lobe, there is a correlative morainic system leading westward from the northeast end of the Highland system that was formed by ice moving southward into Minnesota. In general it comprises two and in places three distinct moraines, as indicated in Plate 3 , but in a few short spaces they are coalesced. In eastern St. Louis County the outer moraine lies south of the Mesabi iron range, but westward from the Embarrass River it lies north of that range and follows its north base into the edge of Itasca County. From a point near Chisholm westward it is covered by a thin deposit of Keewatin drift. The other moraines of this system lie only a short distance north of the Mesabi range for most of their course across St. Louis County and trend with the range slightly south of west, but near

8 Leverett, Frank, Moraines and shore lines of the Lake Superior Basin: U. S. Geol. Survey Prof. Paper 154, pp. 57-63, 1929. 
the west side of St. Louis County they swing northwestward into Itasca County and then take a westward course across the northern part of the county. The morainic belt was mapped by the writer as far west as the Minneapolis \& Rainy River Railway at Kenny, Minn. A thin cover of Keewatin drift is found on this Patrician morainic belt from the vicinity of the Sturgeon River in western St. Louis County westward, but the Keewatin ice caused only a slight toning down of its morainic features.

From a point near the head of the Embarrass River, a few miles east of Tower, a slender moraine branches off from the inner edge of the morainic system under discussion and takes a course north of west along the south side of Vermilion Lake to the west end of the lake. West of that point it was overridden by Keewatin ice and coated thinly with its drift, but the Patrician moraine is traceable westward past the south side of Pelican and Nett Lakes into Koochiching County. It was traced by the writer about 6 miles into Koochiching County but is reported by residents to continue westward between Nett Lake River and the Littlefork River to the point where the latter stream turns northward in the northeastern part of T. 65 N., R. $25 \mathrm{~W}$. It apparently continues westward to the Bigfork River and deflects that stream westward near Big Falls. A considerable part of this moraine was mapped in 1893 by Upham, ${ }^{82}$ who named it Vermilion moraine. He interpreted it to run eastward from Vermilion Lake past Ely, but it seems to the writer to have a more definite continuation southeastward from the lake to the stronger morainic system. The moraine at Ely seems to be of later date and to be definitely developed for only 10 or 12 miles, or for 5 or 6 miles to the east and west from Ely. Winchell ${ }^{83}$ gives the Vermilion moraine a southeastward course in his map of the northern part of St. Louis County, published six years later than Upham's report. Upham stated that the Vermilion moraine continues westward from the west end of Vermilion Lake past the south side of Pelican and Nett Lakes, and the writer found this to be its course. But Winchell in the map just cited represents the course of the moraine to be northwestward past the east side of Pelican Lake to Kabetogama Lake. There is, however, a more scanty deposit of drift along this course than on the south side of Pelican and Nett Lakes and but few places where the drift is in definite knolls of morainic type. This district was also covered by the Keewatin ice, and some of the drift was derived from that source.

There is a moraine of Patrician drift running southwestward from International Falls past Nakoda, Upham, Warren, Minnesota Geol. and Nat Hist. Survey Twenty-
second Ann. Rept., p. 51, 1893 .

Winchell, N. H., Geology of Minnesota, vol. 4, pl. 67, 1899.
Minn., which is distinctly developed for about 15 miles with a width of $1 \frac{1 / 2}{2}$ to $21 / 2$ miles. It stands just within the limits of the Keewatin ice movement, but carries only a thin veneer of Keewatin drift.

The rock ledges on the borders of Rainy Lake and also to the southwest for a few miles within the limits of the Keewatin ice movement have striae with a southwesterly bearing that is consistent with the Patrician ice movement. But at Fort Frances, on the Canadian side opposite International Falls, eastwardbearing striae were noted, and the eastward-bearing striae are found at numerous points on the borders of the Bigfork Valley, also along the Littlefork Valley from central Koochiching County southeastward into western St. Louis County, thus showing that the Keewatin ice had weak action for only a few miles near its outer limits.

Upham ${ }^{84}$ estimated that the main morainic strips in the vicinity of Vermilion Lake and Ely have about 40 feet of drift, but that there is not more than 5 feet of drift in much of the nonmorainic area. He estimated about one-tenth of the surface to be nearly bare rock. It is probable that this estimate will hold for the greater part of St. Louis, Lake, and Cook Counties to the north of the morainic belts just outlined. Some of the valleys, however, carry a filling of considerable depth.

Northeastward from the junction of the Highland morainic system of the Superior lobe with the correlative Patrician morainic belt, from eastern Lake County a few miles into Cook County, eskers of considerable prominence were developed. Some of them are nearly 100 feet high. They seem to have been formed about at the line of meeting of the two ice movements.

\section{WISCONSIN GRAY DRIFT (DES MOINES LOBE)}

\section{GENERAL FEATURES}

The young gray drift of Minnesota and neighboring parts of the Dakotas and Iowa was formed by an ice sheet that extended southward from central Canada, with an axis of movement in the Red River Valley. The main lobe continued from the head of the Red River southeastward along the Minnesota Valley to the bend near Mankato, Minn., and thence southward into Iowa and down the Des Moines Valley as far as Des Moines. This is commonly known as the Des Moines ice lobe but has also been termed the Minnesota-Iowa lobe. A smaller lobe extended down the James River Valley in South Dakota to the Missouri River. This is known as the James River lobe but more commoniy as the Dakota lobe. The junction of the two lobes is at the north end of the Coteau des Prairies in northeastern South Dakota and is marked by an intricate network of morainic ridges and out-

\footnotetext{
s Upham, Warren, op. cit., p. 52.
} 
wash plains. Several moraines of each ice lobe, down to and including the Gary moraine, are here massed together. Within a short distance those of the Des Moines lobe separate into three distinct morainic belts, known as the Bemis, Altamont, and Gary moraines, from villages located on them in eastern South Dakota. The moraines on the east side of the Dakota lobe, however, are massed into a single broad morainic system from this junction southward nearly to the end of the ice lobe. In the vicinity of Sioux Falls the inner moraines swing around to the west and become distinctly separated from the outer part of the morainic system. These have been mapped by Todd ${ }^{85}$ in more or less detail.

There were two sublobes on the east side of the main Minnesota-Iowa or Des Moines lobe, one extending northeastward from the Mississippi Valley above Minneapolis to the St. Croix Valley near Grantsburg, Wis., known as the Grantsburg sublobe, and the other extending southeastward across the Mesabi range and spreading out in the St. Louis and upper Mississippi Basins, known as the St. Louis sublobe. These sublobes extended into territory that carries a deposit of Wisconsin red drift. The gray drift of the Grantsburg sublobe thus overlaps the red drift at least 75 miles and that of the St. Louis sublobe nearly as far. The outer moraines of the Grantsburg sublobe appear to be correlative with those of the Des Moines lobe and thus indicate that the movement of ice in the region occupied by the Wisconsin gray drift culminated later than that which laid down the Wisconsin red drift. The correlation of the moraines of the young gray drift with moraines of the Superior, Michigan, and Huron Basins is taken up in a recent report, ${ }^{86}$ in which the outer moraines are shown to be probable correlatives of the Port Huron morainic system.

\section{BEMIS MORAINE IN SOUTH DAKOTA}

Extent.-The Bemis moraine, named from the village of Bemis, in Deuel County, S. Dak., has its northernmost exposure in the southwest township of Roberts County, in the vicinity of Ortley, S. Dak. (See figs. 11 and 12.) There are in this township groups of morainic knolls, surrounded by gravel plains, in which the headwaters of the Big Sioux River take their rise. A continuous morainic ridge sets in on the south side of the Big Sioux about 2 miles west of Summit, near the line of Roberts and Grant Counties, with an altitude at the county line of about 2,000 feet. The base of the moraine is about

${ }^{85}$ Todd, J. E., The moraines of southeastern South Dakota and their attendant deposits: U. S. Geol. Survey Bull. 158, 165 pp., 1899; U. S. Geol. Survey Geol. Atlas, Parker follo (No. 97), 1903; Elk Polnt follo (No. 156), 1908.

so Leverett, Frank, Moraines and shore lines of the Lake Superior Basin : U. S. Geol. Survey Prof. Paper 154, pp. 38-39, 1929.
1.925 feet above sea level on the west and 1,935 feet on the east. The Big Sioux River is about 50 feet iower, or 1,875 feet above sea level, where it crosses the county line.

The outer border of the moraine leads through the western part of T. 121 N., R. 51 W., from sec. 6 to sec. 32 , and it has a relief along its border of 30 to 50 feet. The drainage from it is westward through Indian Creek and is tributary to the Big Sioux River. Very little outwash is present along the border of the moraine in this township, there being till of preWisconsin age in the outer border district. The inner or eastern slope of the moraine drains northward to the Big Sioux River from sec. 15, but within a mile or two southeast from that locality the drainage goes to the Minnesota River. The moraine has a general width of 2 to 3 miles in this township.

After crossing the line of the old Sisseton and Wahpeton Indian Reservation into T. 120 N., R. 52 W., the moraine bears south-southeastward through the eastern part of that township and the western part of 'T. 120 N., R. 51 W., its outer border being in secs. 15, 23,26 , and 35 , T. 120 N., R. 52 W., and its inner border running from the western part of sec. 6, T. $120 \mathrm{~N}$., R. $51 \mathrm{~W}$., to the southeastern part of sec. 33 . There is a gravel plain about a mile wide on the inner border of the moraine, which is an outwash from the Altamont moraine.

This gravel plain now drains through the Altamont moraine to the Minnesota River. The inner slope of the Bemis moraine drains into this gravel plain and thence to the Minnesota River.

The Bemis moraine enters Codington County at the line of T. 119 N., Rs. 51 and 52 W., but covers only the northeast corner of T. 119 N., R. 52 W. It is crossed by the Great Northern Railway immediately west of South Shore, in T. 119 N., R. 51 W. It has a general width of about 2 miles in this township and leaves the township near the middle of the south line. It continues across T. 118 N., R. 51 W., in a course slightly east of south, its western edge being about a mile east of Waverly, and it maintains a width of about 2 miles in this township. Between it and the Altamont moraine there is a great depression, crossed by the Minneapolis \& St. Louis Railroad directly west of Troy, which is poorly drained and occupied by a chain of lakes, one directly south of Troy and others in northwestern Deuel County. The moraine runs through the eastern edge of T. 117 N., R. 52 W., and is crossed by the Chicago \& Northwestern Railway between Kranzburg and Goodwin stations. Its crest at the railroad crossing is nearly on the line of Codington and Deuel Counties.

In Deuel County the moraine passes through Bemis, on the Chicago, Rock Island \& Pacific Railroad, and lies southwest of that railroad from Bemis to Brandt. 


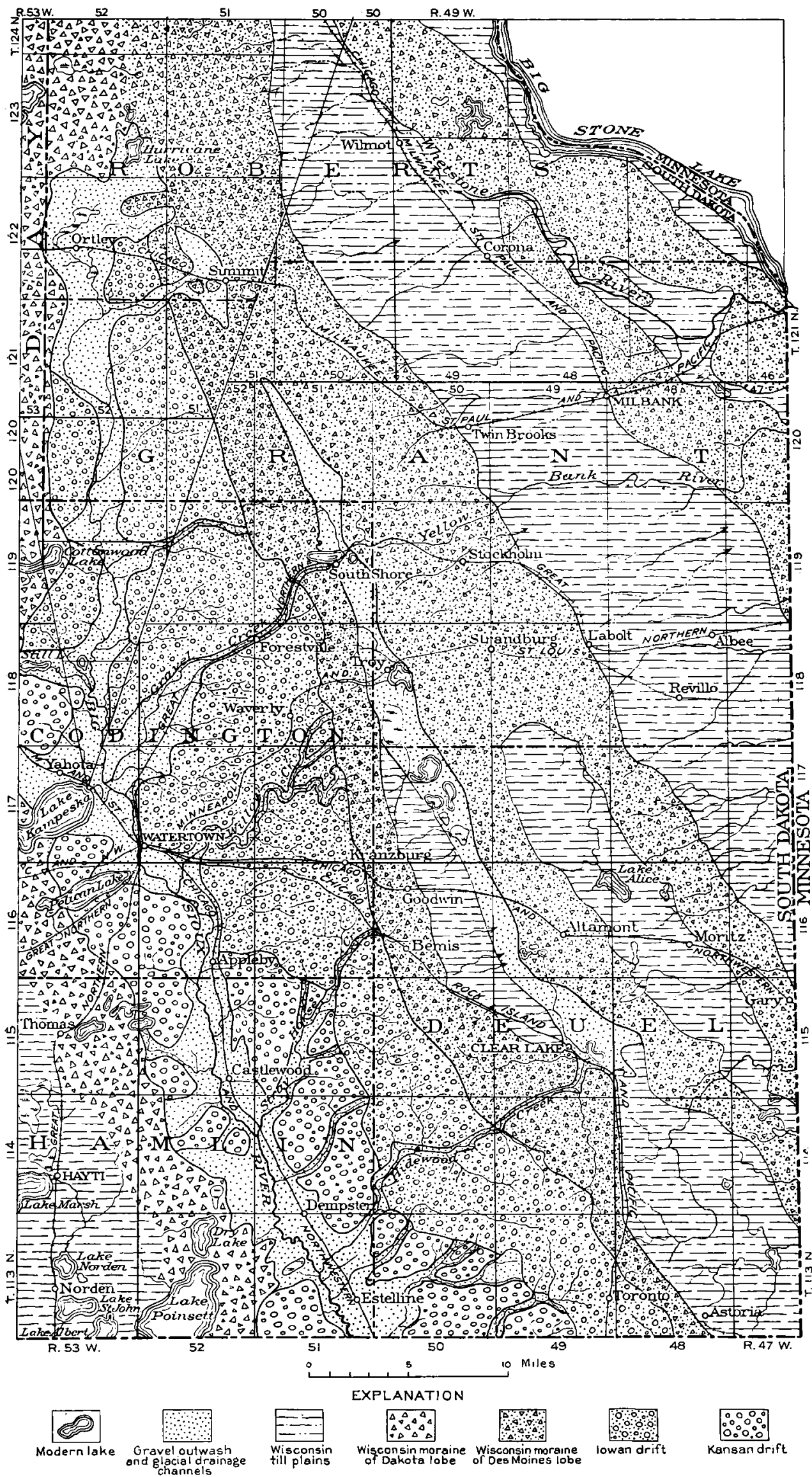

Figdri 11.-Map showing relation of moraines of the Des Molnes and Dakota ice lobes near their function in the northern part of eastern South Dakota
Its inner border is just outside the village of Clear Lake. It passes to the east side of the railroad near Brandt and maintains a southeastward course a cross northeastern Brookings County, passing just west of Astoria, Oak Lake, and Lake Hendricks. It becomes reduced in this county to a width of but little more than a mile but is of great prominence on the inner border, its crest being about 150 feet above the plain that lies east of it. The relief on the outer border is only 30 feet, and its crest is scarcely as high as the highest points on the Coteau des Prairies to the west of it, near Toronto.

Characteristics.-Throughout its course in South Dakota the Bemis moraine is exceptionally bouldery, there being places where the boulders literally cover the ground over many acres. 'They are mainly granite and reach a maximum size of 6 feet or more. The number of boulders is notably greater than on the outlying strip of Iowan drift to the we st, a lready described. Throughout its course the moraine has a strong expression, with sharp knolls 30 to 50 feet high and a network of swales and basins among the knolls. There has been decidedly less toning down of prominent knolls than in the outlying Iowan drift.

The moraine is crossed directly south of Clear Lake by Hidewood Creek, a tributary of the Big Sioux River and the outlet of Clear Lake. This line of drainage seems to have served as an outlet for ponded waters between the Altamont and Bemis moraines in northwestern Deuel County and as far north as the Indian reservation line in Grant 
County. At present this district drains eastward through the Yellowbank River to the Minnesota River, across the Altamont moraine. But from the region near South Shore to the vicinity of Clear Lake neither the Bemis nor the Altamont moraine is crossed by a drainage line, and a chain of lakes is present in this poorly drained area. The valley of Hidewood Creek where it crosses the Bemis moraine is about 150 feet in depth, but the bottom is scarcely oneeighth of a mile wide in its course through the moraine. A small area on the inner border of the moraine in central Deuel County, from the vicinity of Brandt southeastward, has northeastward drainage through the Altamont moraine to the Minnesota River.

A deep depression leads across the Bemis moraine from Lake Hendricks southward. North of the line of the crest of the moraine it is drained into Lake Hendricks and thence to the Minnesota River, but south of that line the drainage goes south to Deer Creek and thence to the Big Sioux River. There are no knolls on the divide in this depression, and it seems to have been the line of a southward discharge of glacial waters near the inner border of the moraine. This channel may also have served as an outlet for glacial waters ponded between the Altamont and Bemis moraines, from points as far north as Brandt, beyond which, as indicated above, the ponded waters found escape through the valley of Hidewood Creek. This depression is about 150 feet lower than the neighboring parts of the Bemis moraine, and its bed is scarcely a quarter of a mile wide.

\section{BEMIS MORATNE IN SOUTHWESTERN MINNESOTA}

Extent.-The course of the Bemis moraine in Lincoln and Pipestone Counties, Minn., was traced by Upham, ${ }^{87}$ who called the moraine "the western or outer terminal moraine forming the crest of the Coteau des Prairies." It has a general southeastward course across Shaokatan, Drammen, Diamond Lake, and Lake Benton Townships, in Lincoln County, and is about $11 / 2$ miles wide. The highest part of its crest, in the vicinity of the State line, is fully 1,950 feet above sea level, and, according to Upham's barometric determinations, its altitude is above 1,950 feet for more than half its course

${ }^{87}$ Upham, Warren, Geology of Minnesota, vol. 1, p. 602, pl. 28, 1884. $67665-32-5$ across Lincoln County. Both northwest and southeast of Lake Benton it reaches nearly 2,000 feet, yet the relief on the outer border is generally not more than 50 feet, the altitude at the base of the outer slope being above the 1,900-foot contour. There are three deep gaps in the moraine, one at the State line, one southwest of Lake Shaokatan, and one at Lake Benton village. The deepest channel is at Lake Benton and is about 200 feet below points on the moraine within 1 to

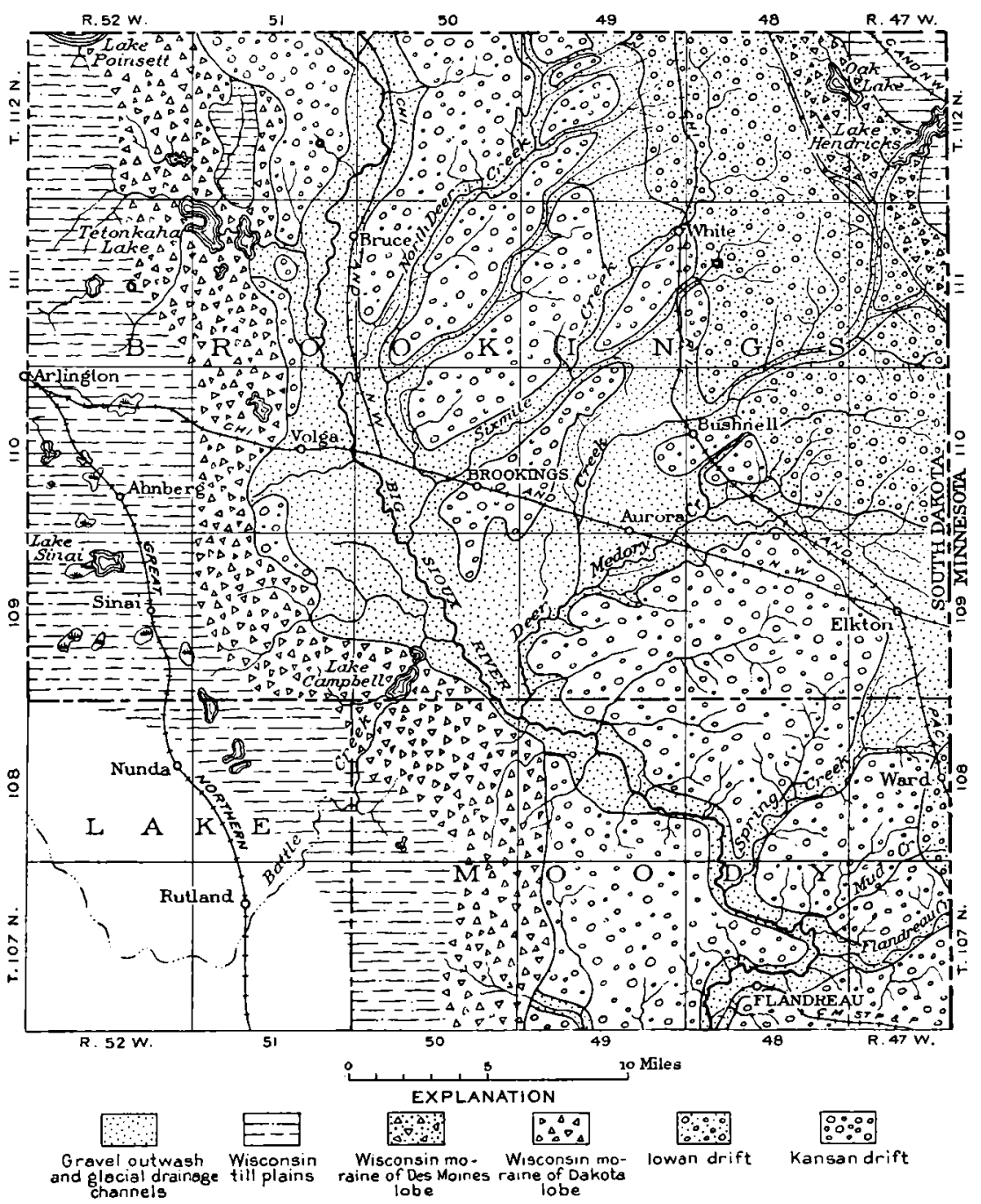

- Map showing relations of moraines of the Des Molnes and Dakota ice lobes ear their Junction in the southern part of eastern South Dakota

2 miles either northwest or southeast. Lake Shaokatan now drains northeastward across the Altamont moraine, but at the time that moraine was forming ponded water between it and the Bemis moraine found outlets through the gaps in the Bemis moraine.

In its course across northeastern Pipestone County the Bemis moraine has a general altitude between 1,900 and 1,950 feet and an outer-border relief of about 50 feet. Its usual width is about 2 miles. From its western slope there was drainage to the Big Sioux River by way of Flandreau Creek and the Rock 
River. From its eastern slope the drainage now goes partly northeastward through the Redwood River to the Minnesota River and partly southeastward through the Des Moines River to the Mississippi. The source of the Des Moines River is in the southeastern part of the northeast township of Pipestone County.

In Murray County the moraine maintains great prominence as far south as the valley of Chanarambie Creek, at Chandler, in the southwestern part of the county. Buffalo Ridge, south of the Chicago, St. Paul, Minneapolis \& Omaha Railroad, and part of the moraine to the north rise above the 1,900 -foot contour, but in general the crest is between 1,800 and 1,850 feet. The outer-border relief is from 30 to 100 feet. Where the moraine is crossed by the railroad the relief is not more than 30 feet, but on Buffalo Ridge, 2 miles south, it is 100 feet. Chanarambie Creek has its sources on the inner slope of this moraine and follows the inner border southeastward into the southwestern part of Leeds Township. It there makes an abrupt turn westward and crosses the moraine near Chandler, in a gap that is below 1,700 feet, or more than 200 feet lower than neighboring parts of the moraine.

From Chandler southeastward there are two slender moraines (see pl. 3), whose combined bulk is no greater than that of the one moraine north of Chandler, and which appear to be the continuation and equivalent of the Bemis moraine. They traverse the southern part of Murray County and run through central Nobles County in a general south-southeasterly course, with a narrow till plain between them. The outer moraine runs from Chandler to St. Kilian and is crossed by the Chicago, Rock Island \& Pacific Railroad just west of Wilmont. It becomes double for a few miles, from the southwestern part of T. $103 \mathrm{~N}$., R. 41 W., southward to the Chicago, St. Paul, Minneapolis \& Omaha Railroad, where it crosses the Little Rock River east of Rushmore. There is a narrow gravel plain between the two members of the moraine where it has this double phase. South of the railroad it continues as a single moraine into Iowa, passing by the village of Bigelow.

The inner moraine branches off from the Bemis moraine about 2 miles west of Iona, runs south-southeastward to Reading, and crosses the Chicago, St. Paul, Minneapolis \& Omaha Railroad directly west of Org Junction. It then swings eastward and runs into Iowa from a point near the southeast corner of Nobles County, Minn.

Characteristics.-The portion of the moraine in Lincoln, Pipestone, and western Murray Counties is so loose textured as to absorb a large portion of the rainfall. Many cobblestones and boulders are embedded in the till, and the moraine also contains gravel knolls and gravel pockets in the midst of the till.
The glacial drainage from this part of the moraine came chiefly from the deep gaps above noted, but there is also gravelly outwash along the border in the southern part of Lincoln County and along much of its course in Pipestone County, extending out in places a mile or more from the base of the moraine. The portion in eastern Pipestone County opens southward along two tributaries of the Rock River which unite west of Woodstock. There is a narrow gravel plain in the vicinity of the Chicago, St. Paul, Minneapolis \& Omaha Railroad between the Bemis moraine and the pre-Wisconsin ridge on which Woodstock stands. From Chandler there was a strong line of glacial drainage down the valley of Chanarambie Creek.

The moraine is very rugged in the vicinity of Chandler, north and east of Chanarambie Creek. A prominent spur of gravelly hills extends northeastward from Chandler to Hadley and covers the greater part of the southeast half of T. 106 N., R. 42 W., with slight extensions into the bordering townships on the east and south. There appears to have been a sublobe of the ice projecting down to Chandler from the vicinity of Hadley, Lake Wilson being in the midst of the district which it occupied. This spur of gravelly hills formed its eastern border.

The slender moraines southeast of Chandler are generally of clayey constitution. They have a relief in places of scarcely 20 feet above the outer-border plains. The knolls are usually from 5 to 15 feet in height. Some of them are widely scattered, with nearly plane surfaces among them. But on the whole the moraines are sufficiently definite to be. readily traced throughout their course in Minnesota.

There was glacial drainage from the outer ridge along each of the streams that led away from it in southern Murray County and in Nobles County. It seems, however, to have been rather weak and to have filled the valleys to slight extent. The drainage down the Kanaranza Valley, for instance, seems to have been too weak to carry the gravel as far as Adrian, which is only 8 to 10 miles from the point where the stream emerges from the moraine. The drainage down the Little Rock River was only sufficient to form a narrow strip of gravel, considerably less than 1 mile in width. Outwash from a recess in the moraine directly west of Bigelow covers 2 or 3 square miles in southern Nobles County and extends slightly into Iowa.

\section{BEMIS MORAINE IN IOWA}

Extent.-The Bemis moraine is split up still more in Iowa than in Minnesota (fig. 7), there being in places four distinct morainic ridges in Osceola and Dickinson Counties. These morainic ridges have a much more easterly course than in the neighboring part of Minnesota and lead to the western edge of the Altamont moraine in southwestern and southern 
Dickinson County and northeastern Clay County in Iowa. The Altamont moraine has a southward course where these earlier moraines come to it, and this course is continued across Emmet and Palo Alto Counties and southeastern Clay County into northwestern Pocahontas County, Iowa. In southeastern Clay County a moraine, which is considered the probable continuation of the Bemis moraine, comes to riew outside the Altamont moraine. This outlying moraine is weaker than the Altamont and differs but little from ground moraine in its course around the southern part of the Des Moines lobe. But it is strong on the east side of that lobe from Marshall County northward, as shown in the county reports of the Iowa Geological Survey, to which reference may be made for a description of the moraine.

Characteristics.-The several members of the Bemis morainic belt in Osceola and Dickinson Counties have a subdued swell and sag topography, with knolls 20 feet or less in height. There is, however, a very prominent gravel knoll, or kame, near the village of Ocheyadan, known as Ocheyadan Mound, which rises about 100 feet above the bordering districts and forms a very prominent landmark. It is one of the highest points in the State of Iowa, the altitude being about 1,670 feet above sea level.

The outwash from the several members of the Bemis moraine in Osceola and Dickinson Counties is of very slight extent. In Dickinson and Clay Counties, to the south of Lake Okoboji, there is an extensive outwash plain leading southward past Spencer. It seems likely, however, that this outwash was derived largely from the Altamont moraine.

\section{BEMIS MORAINIC BELT ON EAST SIDE OF DES MOINES} LOBE

The maps and descriptions of the outer morainic belt on the east side of the Des Moines lobe in Iowa, contained in reports of the Iowa Geological Survey, show it to vary greatly in width and in strength, there being spurs on its inner border, some of which extend several miles westward. The topography also ranges from a gently undulating type to a sharp knob and kettle type. These reports do not separate the morainic belt into distinct members.

In southern Minnesota there is much complexity in the Bemis morainic belt, and in places it is separable into four or five members (see pl. 3), with narrow intervening till plains and strips of outwash. Four distinct members enter Minnesota from Iowa, the outermost 5 miles east of Gordonville, a second directly east of that village, a third 5 miles west, and a fourth 3 miles farther west, directly east of Emmons. The entire series lies east of Albert Lea and Clark Grove but is spread over most of the eastern half of Freeborn County. If crowded together the width would be only 5 or 6 miles, but they are spread over a width of 15 miles or more. The outermost member runs into the western edge of Mower County, west of Austin and Ramsey. The Chicago, Milwaukee, St. Paul \& Pacific Railway crosses five morainic ridges of this series between Albert Lea and Ramsey. The moraines do not run in parallel courses, but instead they split up and then come together, so that the third moraine in one cross section may be the correlative of the second or the fourth in other cross sections. These complications are set forth on the glacial map.

The Bemis morainic belt is not so diffuse in Steele County as in Freeborn, yet its members occupy a width of 10 or 12 miles, mainly east of the Straight River. But from Owatonna northward to Faribault one morainic ridge lies west of the river. There is a very weak moraine in western Dodge County, marking the outer limit of the Wisconsin drift. The moraines converge in southern Rice County to a width of only 5 or 6 miles at Faribault. About 5 miles north of Faribault this morainic belt and the Altamont become merged into a single broad morainic system in which it is difficult to draw the line of separation. It is probable that only the eastern third lies outside the Altamont morainic system in the north half of RiceCounty and in Scott County. The morainic features are much weaker along the eastern edge of the Wisconsin drift in northern Rice County and southwest-ern Dakota County than at a line 3 or 4 miles inside the drift limit. But near Lakeville the strong morainic topography extends out to the edge of the gray drift. North from Lakeville a strong red-drift moraine (St. Croix) is overridden by this strong graydrift moraine, thus giving exceptional strength of expression. This is the condition at the border of the Minnesota Valley.

The district north of the Minnesota Valley lies: within the limits of the Grantsburg sublobe and is discussed by Sardeson on pages 78-90. The Rush Lake morainic system of the Grantsburg sublobe, with its four members, seems to be the equivalent of the Bemis. morainic belt.

\section{BEMIS MORAINE AND LIMITS OF YOUNG GRAY DRIFT NORTH OF GRANTSBURG SUBLOBE}

The moraines in the Grantsburg sublobe are described below by Sardeson. It is probable that the outer system of moraines in the sublobe, the Rush Lake morainic system, may be correlated in a general way with the Bemis morainic belt. The young gray drift north of the Grantsburg sublobe is so complex as to be difficult to interpret, and such interpretations and correlations as are here made are thus more or less tentative. It is found that parts of the border lack a definite moraine and that moraines near the border vary greatly in trend and in strength and thus pre- 
sent a marked contrast to the regular and parallel system of ridges on the southwest border of the ice lobe.

The west base of the Grantsburg sublobe is in the northwestern part of Wright County and the adjacent part of Stearns County. A moraine connects with the moraines of this sublobe directly west of Annandale and bears northwestward past Kimball to the valley of the Sauk River south of Richmond. It forms the border of the young gray drift for most of the 20 miles of this interval. Beyond this point there are two moraines. One that turns southwestward directly away from the gray-drift border is tentatively included in the Altamont morainic system. This seems to be combined with the Bemis morainic belt to the southeast, to form the morainic belt that runs from Kimball to Richmond. The other moraine, which is thought to be the Bemis, becomes distinct on the north side of the Sauk River near Richmond and takes a northwestward course to Sauk Center, crossing the Sauk River south of New Munich. A thin deposit of young gray drift covers a strip several miles wide outside of this moraine east of the Sauk River from the vicinity of Albany to Sauk Center. There is also a small area outside the moraine east of Richmond, near Cold Spring, on each side of the Sauk River.

To the north of Sauk Center, in southwestern Todd County, there is a strip with nearly level surface for several miles west from Sauk Lake. But from Little Sauk past Round Prairie to Long Prairie small hummocks 5 to 10 feet high form a weak morainal border. 'This, however, does not seem to be the full equivalent of the Bemis morainic belt, which is probably represented in a more definite belt running northwestward from Sauk Center past West Union to the south end of Osakis Lake. The Bemis may be the equivalent of both moraines. There is a gap some 3 miles wide at Osakis Lake. North of this gap a definite moraine sets in at the east bluff of the lake and runs eastward past the south side of Maple Jake, and then northeastward to the Long Prairie River at the bend west of Long Prairie, thus nearly coming to the border of the young gray drift. This singular zigzag course of the moraine away from and back to the border in southwestern Todd County is perhaps no more remarkable than the apparent lack of any definite morainal continuation beyond Long Prairie. Perhaps at this time the ice border faced directly north for a few miles, from Long Prairie to Clotho, with its edge near the eastward-flowing part of the Long Prairie River, but it did not form a definite moraine between these points. From Clotho a moraine, which may be the Bemis, is traceable northward through the western edge of Todd County nearly to the line of Wadena
County. It varies remarkably in strength, being very prominent for 6 miles north from Clotho and again just south of the Todd and Wadena County line but relatively weak elsewhere. All along its course, however, small knolls abound, in a strip a mile or more wide, and distinguish it from the smoother surface of the bordering till plains.

There is another moraine that parts from this one at the north bluff of the Long Prairie River near Clotho and takes a course north of west across the rortheast corner of Douglas County into connection with the great "Leaf Hills moraine" of Upham between Miltona and Parkers Prairie. This moraine may be represented south of Clotho in a strip of undulating till that runs south-southwestward into Douglas County on the west side of Osakis Lake but fades out near the south end of the lake. This strip and the moraine in the northeast corner of Douglas County appear to be earlier than the Altamont moraine and more closely related to the Bemis moraine. But, as indicated below, the "Leaf Hills moraine" of Upham should perhaps be correlated with the Altamont moraine.

The features thus far outlined pertain clearly to the young gray drift. There is in Todd County and southern Wadena County a peculiar district which was largely occupied by Lake Wadena in middle Wisconsin time (p. 43). It lies west of the St. Croix morainic system and covers much of Todd County, western Cass County, Wadena County, and bordering parts of Otter Tail, Becker, and Hubbard Counties. Lake Wadena seems to have covered its lower parts, but a considerable part of Todd County stood above the level of that lake. The lake apparently washed part of the outer slope of the St. Croix morainic belt in Todid and Cass Counties. This seems to account for the general absence of an outwash plain and its restriction to high altitudes, as noted in the discussion of that morainic system (pp. 42-43). There seems also to be an abrupt change from the rugged contours of the moraine to a smoother surface at the level of the lake.

The part of Todd County directly west of the northward-flowing part of the Long Prairie River is characterized by numerous elliptical or lenticular hills with a rude resemblance to drumlins. They stand usually about 25 feet above intervening swales but range in height from 10 feet to fully 50 feet. Few of them are a mile in length and the more common length is about half a mile. The width is usually not more than one-third the length. The trend of those in Todd County ranges from nearly due south to south-southwest. A group a few miles northeast of Wadena is shown in Figure 13. Northward from Todd County into Wadena County and bordering parts of Otter Tail and Becker Counties the trend 
gradually changes to southwest and then to westsouthwest. If the ice movement that produced or shaped these hills came from the northeast, there would have been a radiation or spreading of the ice in a southwesterly direction, but if it came from the southwest there would have been a convergence of ice movement toward the northeast. From central Todd County the movement would have been but little east of north, from eastern Otter Tail County about northeast, and from southeastern Becker County more nearly east. This is not inconsistent with what may be inferred as to the direction of the ice movement that brought in the Keewatin drift.

The composition of the drift in the ridges also favors its deposition by the Keewatin ice, for it is calcareous nearly to the surface and carries many limestone pebbles. Such pebbles were noted at depths of only 4 to 5 feet below the crests of the ridges in some of the railway cuts. The surface portion to a depth of about 5 feet is more stony than the deeper portion, and the stones consist largely of granite and other crystalline rocks. There are relatively few stones that can be definitely referred to formations in northeastern Minnesota. Instead the rocks seem more likely to have been brought in from Manitoba and western Ontario. There thus seems to be nothing to oppose the reference of the drift to the Keewatin ice movement.

Inasmuch as this district was covered by the Keewatin ice in some if not all of the earlier glacial stages and as it lies east of the well-defined moraines of Wisconsin drift, it is necessary to consider the possibility that these drumlinlike ridges are of pre-Wisconsin age. The drift in them shows little or no induration of the kind commonly exhibited by the Kansas and Nebraskan drifts in Minnesota. The preservation of the ridge form is also more perfect than seems consistent with the amount of erosion ordinarily shown by these drifts. The evidence thus seems decidedly against referring these ridges to either of these early glacial stages. The Iowan stage remains to be considered. There is a strong probability that the Keewatin ice extended over this district in the Iowan as well as earlier stages. It thus becomes a question whether these ridges are not referable to the Iowan rather than the Wisconsin stage. The state of weathering and erosion may favor their reference to the Iowan stage, for it seems to be somewhat greater than is commonly displayed by the late Wisconsin drift in bordering districts on the west. The writer is accordingly disposed to refer the ridges tentatively to the Iowan stage.
The wide area of sandy and gravelly land that occupies the greater part of Wadena County and the southeru part of Hubbard County is largely within the area covered by glacial Lake Wadena in middle Wisconsin time, but it seems improbable that the sand and gravel are lake deposits. This gravel area appears to have received considerable contributions by glacial drainage from the Keewatin ice in late Wisconsin time. In places the deposits are traceable back to moraines with which they may be correlated. But a large part of the sand and gravel seems to antedate the late Wisconsin invasion.

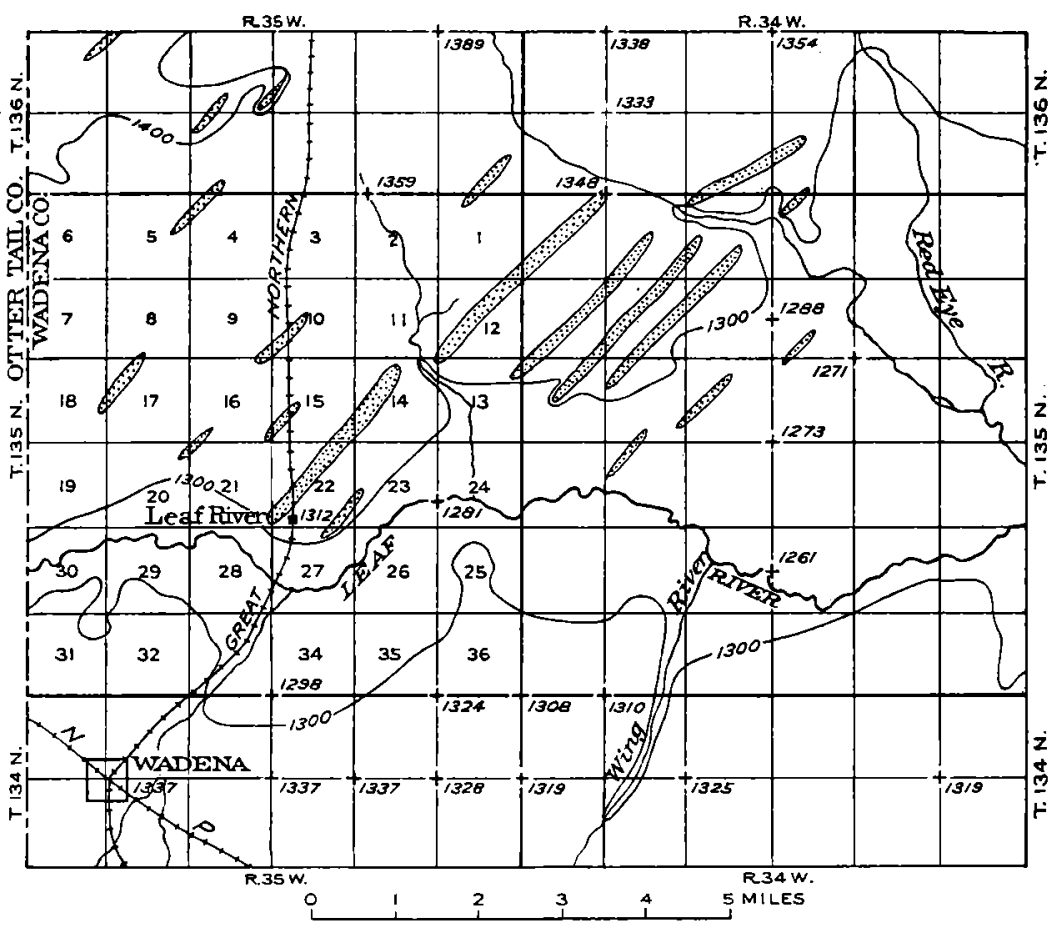

Figune 13.-Drumlinold ridges in Wadena County, Minn.

It is probable that the Keewatin ice sheet covered the till areas of western Wadena County and southwestern Hubbard County, and it may have extended over the gravelly and sandy parts of Wadena County and southern Hubbard County as far as the Crow Wing River, as well as the gravelly and sandy parts of eastern Becker County. The character of the material is consistent with this interpretation. Limestone pebbles abound in it, and the pebbles do not seem to show any striking difference from those in the till areas on the west. A high gravelly plain east of the headwaters of the Crow Wing River near Chamberlin contains material like that of the St. Croix moraine of red drift to the east and was probably formed by outwash from that moraine.

The great morainic belt that lies on the north side of the gravelly area in central Hubbard County and northeastern Becker County is probably part of the 
Altamont rather than the Bemis morainic belt. The Bemis may be represented in short sections or strips of moraine in eastern Otter Tail County and southeastern Becker County. There are strips of moraine with rather weak expression in eastern Otter Tail County, south and east of the village of Deer Creek, that are traceable northeastward to the south side of the Leaf River Valley. North of that valley drumlinoid ridges are conspicuous in western Wadena County and the bordering parts of Otter Tail and Becker Counties, but no definite morainic strips were noted. There is, however, a very prominent morainic tract in southeastern Becker County, extending about 10 miles southeastward from Shell Lake, with a general width of 4 to 5 miles, that seems to lie outside the Altamont morainic system. Yet it may be assigned to that system if the ice border protruded over the great gravelly area of eastern Becker County. The knolls are 30 to 50 feet or more in height, and the general expression is similar to that of the Altamont morainic system.

It is not yet determined whether the sublobe of Keewatin drift in the St. Louis River drainage basin culminated as early as the time when the Bemis moraine was formed or somewhat later. The ice probably maintained an expanded condition in the northern part of the State until it had shrunk materially in the southern part. The St. Louis Basin may, in that case, have remained with nearly its full degree of ice covering down to the time when the Altamont moraine was formed, even if it became filled as early as the time of the Bemis moraine. It seems probable also that the ice would have remained at about its culminating position in the part of Minnesota north of the Mesabi range to a time as late as that of the Altamont moraine. This northern part of the State is still largely unopened, with few roads or trails, and being covered with brush is a difficult region in which to work out details of glacial history. The precise limits of the young gray drift have been determined at only a few places in the district north of the Mesabi range.

The course of the young gray drift border appears to be northward from a point near Chisholm, in western St. Louis County, on the Mesabi range, nearly to the Littlefork River. There was an eastward protrusion of the ice extending 12 to 15 miles into the lowland that borders this stream. North from this lowland the border passes near the west end of Vermilion Lake and continues northward nearly to the international boundary. It then swings westward and runs past the south side of Kabetogama Lake to the west end of Rainy Lake, where it passes into Canada. Its course in Canada, as determined by Johnston, ${ }^{88}$ is

\footnotetext{
Johnston, W. A., Rainy River district, Ontario; Surfeial geology
} and soils: Canada Geol. Survey Mem. 82, p. 123, map, 1915. northwestward to the Lake of the Woods. In this lake Garden Island is within the limits of the gray drift, but islands farther east and north are thought by Johnston to be outside its limits. The border strikes the western shore of the Lake of the Woods near the northwest angle, at the north end of the northward extension of Minnesota on that shore. There was thus a broad ice lobe protruding southeastward nearly 100 miles from the Lake of the Woods, with a slight encroachment on Canada, but lying mainly in northern Minnesota.

\section{KEEWATIN DRIFT SOUTH OF MESABI IRON RANGE}

Distribution.-There was a distinct lobation of the Keewatin ice sheet in the St. Louis drainage basin and the part of the Mississippi Valley immediately south of the Mesabi iron range, for which the name St. Louis sublobe has been suggested (p. 57). Its center or axis of movement across the range was not far from the course of the Mississippi River, and it covered the range as far northeast as Chisholm and as far southwest as the northwest township of Aitkin County, near Shovel Lake. Its width on the range was thus nearly 60 miles. On descending into the basin south of the range the ice spread out to a width of about 110 miles, or 50 miles greater than its width on the range. The extension was northeastward toward the source of the St. Louis River, as well as southwestward down the Mississippi Valley. Its northeastern limits in the St. Louis Basin were near Aurora and Markham. The southeast border of the drift deposited by this sublobe runs somewhat directly from Markham to Culver and thence westward on the north side of the St. Louis River to Mirbat. It there crosses the river and runs southwestward past Prairie Lake and Tamarack to Rice Lake, doubles back sharply northward to Axtell, curves around to the west and south to Rossburg, and continues westward down the south side of the Mississippi Valley to the terminus of the lobe at Rabbit Lake, north of Cuyuna. On the north side of the Mississippi it runs northeastward about to Bain and there curves around to the northwest and runs past Shovel Lake village to Big Rice Lake, from which westward it pertains to the general ice sheet.

On the south slope of the Mesabi range the border is sinuous and adjusted to the contours of the range. It falls short about 300 feet of reaching the height of the highest points on the crest from the vicinity of Virginia eastward to the Embarrass Valley, its upper limit being at an altitude of about 1,500 feet. Where the ice overrode the range in the vicinity of Hibbing it covered points over 1,700 feet above sea level.

The altitude along the southeast border declines frum about 1,500 feet near Markham to 1,300 feet or less where the lobe crosses the St. Louis River near 
Mirbat and to about 1,200 feet at the southwest end of the lobe, near Rabbit Lake. As there has been some northeastward differential uplift in this region, there is now a correspondingly greater range in altitude between the northeastern and southwestern parts of the area covered by this ice lobe than at the time the ice was present. This is known from the tilting which the shores of Lake Aitkin exhibit (pp. 65-66).

Relation to Patrician drift.-That the occupancy of this part of the St. Louis and Mississippi drainage basins by the Keewatin ice was later than its occupancy by the Patrician ice, of late as well as middle Wisconsin time, is clearly shown by the superposition of the Keewatin drift on the latest Patrician moraines in northern Minnesota. In places the Keewatin drift is so thin that the morainic knolls and ridges of $\mathbf{P a}$ trician drift which it overlies are distinctly outlined features, with more expression than is common to the Keewatin drift. On Plates 1-3 these overridden moraines are indicated wherever they stand out clearly. Their weaker parts are so deeply covered by the Keewatin drift or in places by sand and silt deposits that they are no longer traceable.

Relation to Superior ice lobe.-This St. Louis sublobe lay immediately west of an ice lobe that occupied and radiated from the Lake Superior Basin, known as the Superior ice lobe. There is a narrow strip of the Patrician red drift exposed between the drifts of these two ice lobes from the St. Louis Valley at Brookston northeastward past the end of the Keewatin drift sheet. But from Brookston southwestward to Rice Lake the borders of the two drifts are almost in contact, and in places the Keewatin drift slightly overlaps the edge of the Superior drift.

The Superior ice lobe appears, therefore, to have culminated and begun its recession before the culmination of the Keewatin ice lobe. This is indicated by the overlapping of the Keewatin drift just mentioned, and also by the evidence of drainage from the Keewatin ice border, including that of glacial Lake St. Louis, into the area that had been occupied by the Superior ice lobe (p. 54).

Topographic features.-.This sheet of Keewatin drift scems to have little or no terminal-moraine topography but instead presents a smooth to gently undulating surface of the ground-moraine type. It veneers knolls and ridges of Patrician drift, as already noted, but it tends to reduce rather than accentuate the roughness of the surface by filling the depressions among the knolls and ridges.

Character of Keewatin drift.-Besides the difference in color (pl. $4, A$ ) the Keewatin drift is generally of a more clayey and less stony character than the underlying Patrician drift, so the two drifts are readily distinguished wherever exposed. The contrast in stoniness is so striking that it is clearly brought out in photographs. (See pl. 4, B.) The Keewatin drift is a calcareous till, containing limestone pebbles brought in from southern Manitoba. Such pebbles are seldom found in the Patrician drift, and the few that occur were probably derived from an underlying old calcareous gray drift, exposures of which are to be seen at the base of the Patrician drift on the borders of the mine excavations. The clayey character of the Keewatin drift is probably due to the incorporation of clayey shale from formations in southern Manitoba and northwestern Minnesota in the path of this ice sheet. It is the prevailing character of the young gray till of western Minnesota.

The color of the Keewatin drift in this lobe south of the Mesabi range is decidedly red and thus distinctly different from the yellow and gray colors of the same drift to the north and west of the range. This red color is probably due, in the main, to incorporation of red material from the iron-bearing formations on the range, rather than to deep oxidation since the drift was deposited.

Probable place in Wisconsin stage.-The drift in this lobe south of the Mesabi iron range seems about as old as the outer part of the sheet of young gray dirift in the Des Moines lobe and the Grantsburg sublobe. It is thus of late Wisconsin age. It seems to fall in the same part of the Wisconsin stage as the Port Huron morainic system, though perhaps not correlative in a strict sense. North of the Mesabi range this Keewatin drift is associated with that of the Vermilion morainic belt of the Patrician ice sheet (p. 56). The gray drift of the Littlefork drainage basin, however, overlaps the Vermilion moraine nearly as far east as the west end of Vermilion Lake and is thus younger than that moraine.

Lake Aitkin.-The name Lake Aitkin has been applied by Upham ${ }^{89}$ to a body of water which for a time covered the low ground on the borders of the Mississippi River in Aitkin County, with slight extensions northward into Itasca County and westward into Crow Wing County. It occupied a basin south of the Mesabi range into which the St. Louis sublobe of the Keewatin ice sheet had a southwestward extension. With the withdrawal of the ice lobe ponded water accumulated at its southwest end and gradually extended with the melting away of the ice. At the same time another lake, glacial Lake St. Louis, was formed in the St. Louis drainage basin along the eastern border of the same receding ice lobe..$^{80}$

The recession of the ice border eventually was sufficient to expose a low strip on the divide between the St. Louis and Mississippi drainage basins near the

- Upham, Warren, Report on Aitkin County : Minnesota Geol. Survey, vol. 4, pp. 46-47, 1899.

Do Winchell, N. H., Glacial lakes in Minnesota : Geol. Soc. America Bull., vol. 12 , pp. 121, 124, 1901. 
Swan River, and the lakes then may have become confluent and taken a common level in harmony with the lower of the two outlets. The level of the two lakes differed so slightly before they became confluent, however, that it may be a difficult matter to determine which lake took the flow of the other.

Lake Aitkin discharged directly down the course of the present Mississippi. Two beaches that differ about 10 feet in altitude are traceable on the borders of this lake. The higher one seems to mark the level of the head of the outlet when the ponding began, and the lower one registers a deepening of the outlet and a corresponding lowering of the level of the lake.

The higher shore line has an altitude of 1,220 to 1,225 feet above sea level from Aitkin west to the head of the outlet. There is a northward rise to 1,230 feet in the vicinity of Palisade and to 1,250 feet at Jacobson. This rise of 25 to 30 feet, which is made in a. distance of about 40 miles, is the result of subsequent northward differential uplift.

\section{OUTWASH AND GLACIAL DRAINAGE ON EAST SIDE OF KEEWATIN ICE SHEET}

The southeastern part of Stearns County and the bordering part of Wright County received the drainage from the ice in the angle between the main lobe and the Grantsburg sublobe, and as a result the low areas carry a coating of gravel and sand. The gravel trains to the southeast of the Sauk River Valley head in the recess between the ice lobes. On the Sauk River the gravel plain below Cold Spring heads at the gray-drift border and fills two low strips, one leading north toward St. Joseph and the other following the present course of the river to St. Cloud. The Sauk Valley later served as a line of discharge for the waters that formed the extensive outwash plain north of what is regarded as the Altamont morainic system in Pope, Kandiyohi, and southern Stearns Counties. The headwater part of the Sauk River received the drainage from the north end of that great outwash plain through a channel leading from Villard past Westport. It is probable that some outwash was deposited in the upper part of the Sauk Valley between Sauk Center and New Munich, at the time the Bemis moraine was forming along the southwest border of the valley.

The Round Prairie outwash plain extends across the present divide between the Little Sauk and Long Prairie Rivers and blocks the mouths of small valleys that come in from the east, which had been opened prior to the culmination of the Keewatin ice movement. Lake Latimer is hel'd in the lower end of one of these valleys by such a filling. Smaller lakes between Lake Latimer and Round Prairie are in basins in the outwash plain. About 4 miles south of Long
Prairie the border of the gray drift crosses to the east side of the valley that drains northward to the Long Prairie River, and the outwash plain gives place to swampy land that lay beneath the ice edge. Along the east side of this valley past Lake Charlotte and the eastern part of Long Prairie numerous small knolls mark the limits of this drift. There was southward drainage to the Round Prairie gravel plain from the east side of Lake Charlotte.

The part of the Long Prairie Valley north of the village is much broader than that west of it and has been filled with a deposit of sandy gravel; part of this area was a prairie at the time of the settlement of this region, whence comes the name. At a few places along the east bluff of the valley enough fresh-looking calcareous till was found to suggest that the Keewatin ice extended across the valley, but the ice seems not to have covered the valley long enough to make a continuous sheet of till at its edge. The sandy gravel contains some limestone and probably is chiefly Keewatin outwash. Inasmuch as the Long Prairie River heads in an extensive outwash plain connected with what is regarded as the Altamont moraine, its valley was the natural line of discharge for glacial waters down to the time of completion of that moraine, and it is not unlikely that considerable material was carried into this broad northward-flowing section of the stream course. The presence of calcareous gravel here is less significant than the patches of fresh calcareous till in showing that the Keewatin ice extended over this part of the valley.

Eagle Creek, which enters the Long Prairie River at Browersville, has a broad gravel-filled valley, in places a mile in width, in the eastward-flowing part below Eagle Bend, but in the northward-flowing part for 4 miles above Eagle Bend the valley is narrow and its bottoms are cut in till. The headwaters are in an outwash plain of sandy gravel, from which glacial drainage would naturally have gone down Eagle Creek. Probably this drainage had a tendency to erode in the northward-flowing part, but deposited sand and gravel in the eastward-flowing part, below Eagle Bend, where its waters were free to spread out.

The next noteworthy glacial drainage line to the north is the Wing River. This stream heads in an extensive outwash plain in southeastern Otter Tail County, part of which is known as Parkers Prairie. The stream traverses a till tract in northwestern Todd County, in a broad gravel-filled valley more than a mile in average width, and then enters the extensive area of sandy gravel that covers much of Wadena County. For about 3 miles, from Hewitt north to the line of Todd and Wadena Counties, it traverses a strip of bouldery till instead of utilizing the broad gravel plain close by on the east. In explanation of 


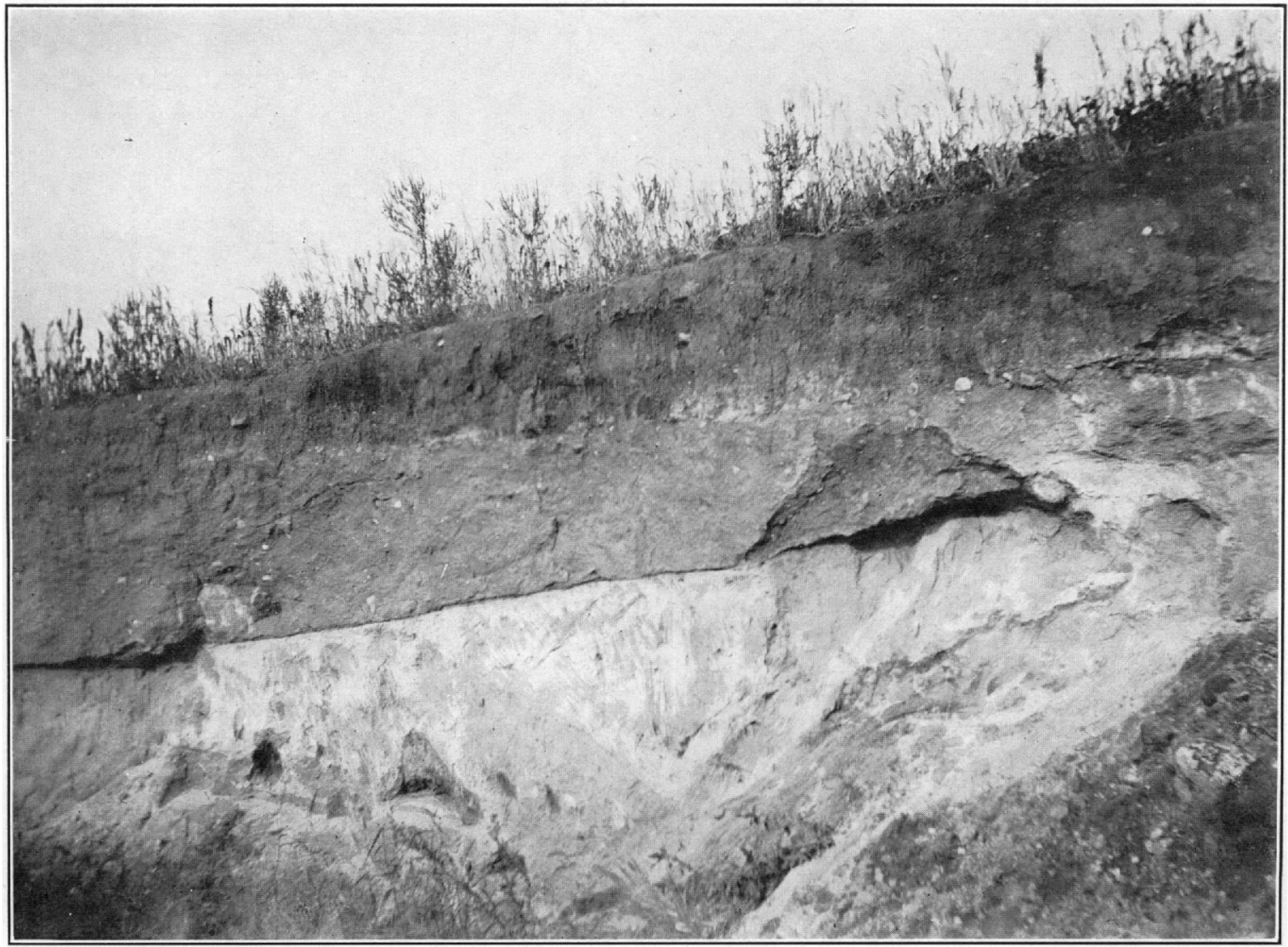

A. WISCONSIN GRAY TILL OF THE KEEWATIN ICF OVERLYING WISCONSIN RED TILI OF THE PATRICIAN ICE, WHICII RESTS ON REDDISII GLACIAL SAND

Photograph by F. W. Sardeson.

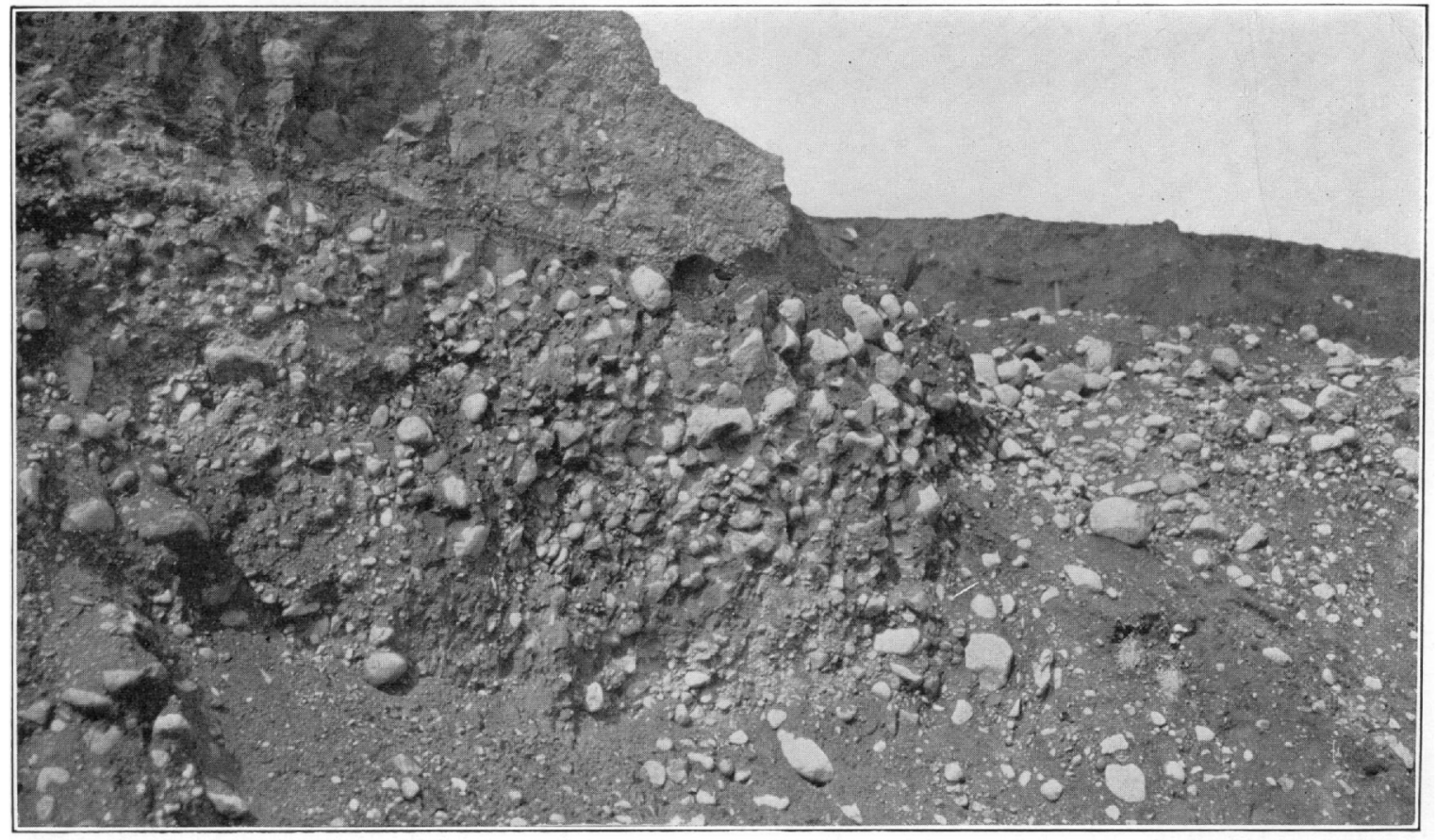

B. WISCONSIN TILL OF THE KEEWATIN ICE OVERLYING STONY TILL OF THE PATRICIAN ICE Mountain Iron open pit, Mesabi iron range, Minnesota. 

chis peculiar course it was at first thought that the Keewatin ice sheet may have covered this strip of bouldery till while the gravelly deposits were being laid down as a direct outwash in the valley on its east border. But the relation of the Wing Valley to the great outwash plain at its head makes it seem probable that glacial waters were depositing material in this part of the valley long after the ice border had withdrawn from this section. The stream may now be following a depression which was to one side of the main flow of the glacial stream and which for that reason remained unfilled. The fresh calcareous gravel carried by this large stream from the Parkers Prairie outwash plain was spread out widely in southern Wadena County, filling the space several miles wide between the Wing and Partridge Rivers and extending down each stream to Leaf River.

In southwestern Wadena County west of Wing River and south of Leaf River there is a tract of several square miles in which the surface is different from a plain of aggradation, though the drift is a loose-textured sandy and pebbly deposit, with little or no admixture of clay. There are a few surface boulders, usually a foot or less in diameter, more or less waterworn. The surface is gently undulating like a till plain or ground moraine, and it is probably a very sandy phase of ground moraine. It is nearly in the line of continuation of the weak moraine that runs northward through western Todd County, but it has too little expression to be classed as a moraine.

The Leaf River has its source in a great outwash plain connected with what is regarded as the Altamont morainic system, and its valley was the line of discharge for a glacial river of considerable magnitude. The channel cut by this glacial stream is half a mile to a mile or more in width in eastern Otter Tail County and southern Wadena County, and 50 to 75 feet in depth. The present stream winds about as a narrow thread in its broad bottoms and has deepened the old valley but slightly.

The Red Eye River also runs in a valley that is too large to have been cut by so small a stream since late Wisconsin time. Its source is in a gravel outwash plain connected with a moraine in southern Becker County that may be the outermost member of the Altamont morainic system. It runs through a till plain of young gray drift in northeastern Otter Tail County and western Wadena County. The valley is 40 to 50 feet deep and a quarter to half a mile wide. Its course is so direct that it affords long views up and down the valley. It is this feature that gives pertinence to the name Hillview, applied to a hamlet standing on one of its bluffs in northeastern Otter Tail County. The present stream has cut an insignificant trench in the bottoms left by the glacial river. $67665-32-6$
The streams in eastern Becker, southern Hubbard, and northern Wadena Counties flow for much of their courses in a great outwash plain of sandy gravel, in which they have cut small valleys consistent with their drainage areas. The glacial waters came in from the west and north from what is thought to be the Altamont morainic system and probably carried material as far out as the borders of the plain of young gray till in southeastern Becker County and western Wadena County. The main line of discharge was down the Crow Wing River. Much of this plain seems to have been ice covered just before the stand was made at the west and north borders, for it contains numerous lake basins which are thought to mark places where masses of stagnant ice remained after the active ice border had receded to the position of the moraine, the outwash material being built around these masses. These lake basins are found in northern Wadena County as well as nearer the morainic systems in Becker and Hubbard Counties. A considerable part of this great outwash area may thus have been overridden by a readvance of the ice that immediately preceded the development of the Altamont morainic system. The gravelly deposit may thus have been built up to some extent as the ice was withdrawing from the area.

\section{ALTAMONT MORAINIC SYSTEM}

Name.-The name Altamont was applied by Chamberlin ${ }^{91}$ to a moraine in eastern South Dakota which he supposed to be the outermost moraine of the latest (Wisconsin) glaciation, the name being taken from the village of Altamont, which stands on it. (See figs. 6 and 11.) The Bemis moraine, which lies only a few miles outside the Altamont in that locality, seems to have been overlooked or unrecognized by Chamberlin as the product of the Wisconsin glaciation. The name Altamont was also applied by Chamberlin to the outermost moraine of the Dakota lobe and has been adopted by later students. But it remains to determine whether this usage is warranted, for the Bemis moraine may lie outside the Altamont. at least on parts of the border of the Dakota lobe. If ordinary scientific usage is followed, the name Altamont should be applied only to the moraine or morainic system that is the equivalent of the one on which the village of Altamont stands.

Eastern South Dakota.-Throughout much of its course in eastern South Dakota the Altamont moraine is so closely associated with the Gary moraine on its inner border that there is rarely a distinct line of separation. The intermorainic strip between them has

a1 Chamberlin, T. C., Terminal moraine of the second glacial epoch : U. S. Geol. Survey Third Ann. Rept., pp. 378, 386, 393, 1883. 
an undulating surface which in places is not clearly distinct from the knolls and ridges of the moraines. Its expression as a rule, however, is milder than that of the moraines. It is in few places as much as 5 miles in width and commonly 2 miles or less.

The junction of the Minnesota lobe and the Dakota lobe at the time the Altamont moraine was forming was in southwestern Roberts County and eastern Day County, S. Dak. (see fig. 11), and a strong interlobate moraine extends northward from this junction across eastern Marshall County and western Roberts County, nearly to the line of North Dakota. Hurricane Lake stands at the junction of the moraines, and an outwash plain leads southward from it down the valley of the Big Sioux River. The morainic knolls bordering the lake reach an altitude of 2,050 feet; the depression in which the lake lies only about 1,900 feet. Other lines of discharge for glacial waters are found both to the southeast and to the west of the one leading from Hurricane Lake, but all of them come together north of Ortley, in a plain 3 or 4 miles in width, drained southward by the Big Sioux River.

The Altamont moraine of the Minnesota lobe passes through the village of Summit and has an altitude of 2,000 to 2,020 feet within the village limits. A short distance southeast of the village the highest points reach fully 2,050 feet. The moraine bears east of south through northwestern Grant County and touches the northeast corner of Codington County. It passes immediately east of Troy and follows the east side of a chain of lakes from 'Troy to Altamont. The border as traced by C. S. Corbett from Altamont to the Minnesota line traverses secs. 22, 21, 16, 17, and 7, T. 114 N., R. 47 W.; secs. 35, 34, 33, 28, 21, 20, 17, and 7 , T. 115 N., R. 48 W.; and secs. 12, 1, and 2, T. 115 N., R. 49 W. In this interval the moraine is very prominent over a width of about $2 \frac{1}{2}$ miles, and a narrow undulating strip separates it from the Gary moraine on the east. This undulating strip continues northward past Lake Alice, beyond which there is a practically complete union of the Altamont and Gary moraines clear to the interlobate moraine at the junction of the Minnesota and Dakota lobes.

Boulders are especially numerous along the crest and on the outer slope of the Altamont moraine and in places make it difficult to cultivate the land, so that some of it is still untilled. The drift is thickly set with stones of all sizes, yet the matrix is usually clayey, especially on the eastern or inner slope.

Lakes are numerous in the depressions in the interlobate moraine, and they are conspicuous features in the moraine of the Dakota lobe for many miles to the south, but in the moraine of the Minnesota lobe they are conspicuous no farther south than Summit. There are, however, lakes in the gravel plain immediately outside the moraine as far south as Clear Lake.
The drainage from the Altamont moraine went westward or southward through gaps in the Bemis moraine into the Big Sioux River, one of these gaps being at Hidewood Valley, near Clear Lake, and another near the State line south of Lake Hendricks. There are others in Lincoln County, Minn., near Lake Shaokatan and Lake Benton. Part of the present drainage leads through some of these gaps into the Big Sioux River. But other streams heading outside the Altamont moraine now flow through the moraine and discharge into the Minnesota Valley. One of these is at South Shore, another east of Brandt, and another near Astoria. These all wind about in depressions among the morainic hills, and not in direct and wide open valleys such as were opened by the lines of glacial drainage.

Southwestern Minnesota.-The Altamont moraine is combined with the Gary moraine from the line of South Dakota and Minnesota southeastward to a locality within about 3 miles of Ivanhoe. The two moraines are thence distinct through much of their course across southwestern Minnesota. The Altamont moraine passes immediately south of Ivanhoe and eastward immediately north of Arco. Near the line of Lincoln and Lyon Counties the moraine turns southward and runs past Florence into the northern edge of Murray County, its inner border being near Burchard, in Lyon County. It then runs eastward for about 12 miles along the border of Murray and Lyon Counties, and turns southeastward past the south side of Lake Sarah. It crosses Lake Shetek near the southeast end of the lake and generally follows the northeast side of the Des Moines River through eastern Murray County, though in places its morainic hills are found on the southwest side of the river, notably about 4 miles northeast of Avoca. In eastern Murray County and southwestern Cottonwood County the moraine is separated into two or three constituent ridges, which unite and separate from place to place, the intervals between them being occupied by narrow, relatively smooth till plains. The main part of the Altamont moraine crosses to the south side of the Des Moines River at Big Bend, in southern Cottonwood County, runs southward past Wilder and Lakefield through central Jackson County, and passes into Iowa near the middle of the south line of the county. The most prominent part of the moraine traverses Tps. 101 to 105 N., R. 36 W., but morainic topography extends as far east as the Des Moines River, the width where most expanded being about 10 miles. Opposite Lakefield the width is about 6 miles, and at the line of Cottonwood and Jackson Counties it is not more than 3 miles. The general width of the moraine in its course across southwestern Minnesota is about 3 miles, but where separated into constituent ridges it may be 5 miles or more. The narrowest part appears to be 
in southwestern Cottonwood County, west of Big Bend, where the width is only about $11 / 2$ miles.

The portion of this moraine in Yellow Medicine, Lincoln, Lyon, and Murray Counties is sufficiently clayey to make good agricultural land, there being few places where it is too stony for cultivation. The clay is so retentive of moisture that the crops usually successfully withstand seasons of drought. Immediately east of Lake Shetek a range of gravelly hills sets in which leads southeastward past Dovray, about to the line of Murray and Cottonwood Counties. There are also a few gravel knolls north of Wilder near the Cottonwood County line. The moraine is gravelly near the south side of Jackson County.

The altitude of the Altamont moraine in southviestern Minnesota is lower than that of the Bemis moraine, for it lies on the northeast slope of the Coteau des Prairies, whereas the Bemis nearly follows the crest. Near the line between South Dakota and Minnesota it is about 1,800 feet above sea level, and its crest maintains an altitude of 1,700 feet as far southeast as Arco and is in places above 1,700 feet still farther south, in the vicinity of Florence. East of Florence the altitude soon drops below 1,600 feet, and the crest of the moraine stands between 1,500 and 1,600 feet throughout much of its course in Murray County. In Cottonwood and Jackson Counties there are only a few segments along the crest that rise above 1,500 fect, the greater part of the moraine being between 1,400 and 1,500 feet. The inner or northeast edge of the moraine is generally 100 to 200 feet lower than the crest.

The Altamont moraine diverges very widely from the Bemis moraine in its course through Murray and Cottonwood Counties and then comes back to that moraine and overrides its several ridges in northern Iowa. The till plain between these moraines has a width of 30 miles in its most expanded part, in southeastern Murray, northeastern Nobles, southwestern Cottonwood, and western Jackson Counties. The plain is remarkably smooth and slopes from the Bemis moraine northeastward to the Des Moines River. The cause for this difference in the courses of the Bemis and Altamont moraines may be found in the prominence of the quartzite range in Cottonwood County in T. 107 N., Rs. 34, 35, and 36 W. (See pl. 3.) This range, which stands nearly 1,500 feet above sea level, may have checked the southward spreading of the ice lobe so that its border at the time of the Altamont moraine was not so far to the southwest as it might otherwise have been. The bearings of striae along the range are in harmony with this interpretation. They bear southeastward on its northwestern part and shift to a southerly trend at its east end. The quartzite range thus appears to have been a buttress over and around which the ice had to pass at the time it was forming the Altamont moraine. The ice was presumably so thick over this range at the time it extended to the Bemis moraine that it had a free flow past the range and did not curve around it.

Iowa.-The Altamont morainic system continues southward in Iowa past Spirit Lake and Lake Okoboji with as great prominence as it exhibits in southern Jackson County, Minn. In central Dickinson County it forms a great loop that embraces Lake Okoboji. (See fig. 7.) East of that lake it doubles back about to the village of Superior and then resumes a southward course through the western part of Emmet and Palo Alto Counties and the eastern edge of Clay County. It loses its prominence in eastern Buena Vista County and northwestern Pocahontas County but is a distinct moraine all the way to the south end of the lobe and includes Mineral Ridge, in northern Boone County. Its course from Buena Vista County to Boone County was determined by J. H. Lees, of the Iowa Geological Survey, some years ago. The results have not been published, but Doctor Lees has kindly supplied the data for outlining its course. It lies some distance inside the limits of the Wisconsin drift of the Des Moines lobe. The Bemis moraine probably forms the limit of the Wisconsin drift from Clay County southward on the west side of the Des Moines lobe.

The Altamont moraine barely enters the eastern edge of Clay and Buena Vista Counties, and its border runs through the southwest township of Pocahontas County. It traverses the western range of townships in Calhoun County and passes through Lavinia and Lake City. After cutting across the northeast corner of Carroll County it swings eastward and crosses northern Greene County about 6 to 8 miles from its north line, the village of Dana being on it. It continues its eastward course in Boone County, where prominent parts, Pilot Mound and Mineral Ridge, have been recognized as morainic features since they were first pointed out by White ${ }^{92}$ in 1870 . The moraine is as a rule about 2 miles in width but in places is narrower. In the northern part, from Albert City, Buena Vista County, northward, its width is greater than 2 miles, in places 6 miles or more. The ice border may have held its position there while making considerable retreat in the southern part of the lobe. In that event the moraine traced around to Mineral Ridge is only a partial representative of the Altamont system. There may be weak moraines in the district east and north of the one traced by Lees which have not yet been traced, for the district has not been carefully examined. The moraine traced by Lees is reported by him to have considerable relief in Greene County, in places 60 to 80 feet above the plain outside, though the usual relief is between 20 and

${ }^{22}$ White, C. A. Geology of Iowa, p. 99, 1870. 
40 feet. It has a gentle swell and sag topography, with here and there a prominent knoll, such as Pilot Mound, 50 feet or more in height. The prominent knolls are liable to be gravelly, but otherwise the moraine consists of clayey till with only a slight amount of interbedded gravel. The part north of Albert City contains many sharp knolls 50 feet or more in height and several lake basins. It is thus in striking contrast to the moraine leading from Albert City to Mineral Ridge.

In June, 1921, Doctor Lees and the writer took up the tracing of the Altamont moraine in Boone County and mapped its course across Boone, Story, Hardin, Hamilton, and Wright Counties, and the writer continued the mapping northward across Hancock and Winnebago Counties, Iowa, into connection with work previously done in Minnesota. The topographic maps of the Boone and Ames quadrangles indicate its course and its topographic expression across much of Boone County and the northwest corner of Story County. It crosses the Des Moines River just above Fraser in a slight protrusion to the south between Pilot Mound and Mineral Ridge. The river is in a narrow valley 250 feet deep where it passes through the moraine. As the moraine stands only 30 to 40 feet above the outer border plain here, the valley is cut far below the level of its base. To the northeast past Mineral Ridge the relief of the moraine is about 80 feet in the most prominent places but is generally only 50 feet. The width is but little more than a mile at Mineral Ridge village, but 5 miles farther east it spreads out to fully 3 miles. It narrows to about a mile at the Squaw Creek Valley, at the border between the Boone and Ames quadrangles, but widens to fully 3 miles at the line of Boone and Story Counties, its inner border being in the edge of Hamilton County. It there takes a sharp turn to the southeast, follows the south side of Keigley Branch to the Skunk River, and crosses that valley 5 or 6 miles above Ames. It is exceptionally weak in the vicinity of this valley, with a relief of but 20 to 30 feet or even less and a width of but 1 to 2 miles. A short distance east of the limits of the Ames quadrangle the moraine swings abruptly northward and follows the east side of Bear Creek to the south end of the line between Hardin and Hamilton Counties. There was thus a distinct protrusion of the ice border 4 or 5 miles southward in crossing the relatively low tract through which the Skunk River flows.

The Altamont moraine follows the line of Hardin and Hamilton Counties for about 15 miles north from its south end, the outer edge of the moraine being within a mile east of the county line, and the inner edge usually within 3 miles west. Farther north it lies almost wholly in Hamilton County. One ridge lies between Bear and Long Dick Creeks and another east of Bear Creek, in the southeast township of Hamilton County, but they are not so distinct farther north. In the vicinity of the Chicago \& Northwestern Railway the ridges are united and the moraine has a relief of about 50 feet above the plains on each side. From Iowa Lake southward to the Story County line the moraine shows knolls 20 to 40 feet high in nearly every section, and thus has a stronger expression than to the north, in northeastern Hamilton County, where there are flat areas separating strips of gently undulating land that rise only 15 to 25 feet above them.

MacBride's map of the surface deposits of Hamilton County ${ }^{93}$ shows a narrow morainic ridge in the eastern part of the county. It follows the west side of the Skunk River from Randall northward to the head of the stream, except for a few knolls on the east side about 3 miles southeast of Blairsburg. It is only about a quarter of a mile in average width but is practically continuous for a distance of 20 miles. It has a hummocky surface and a relief of 15 to 25 feet. This moraine should perhaps be included in the Altamont morainic system. It is only 3 to 6 miles from the inner edge of the main moraine, and appears to be united with the main moraine from the head of the Skunk River northward.

There is some uncertainty as to how much of the morainic complex in counties farther north should be included in the Altamont morainic system. Probably the very strong morainic system lying west of the headwater part of the Iowa River falls in that system, and it may also include part of the morainic area east of the river. The present description, however, applies only to the morainic belt west of the river.

In the southeast township of Wright County the moraine has on its outer border an extensive outwash plain that fills the interval between it and Iowa River. There is also a gap about a mile wide in the main ridge of the morainic system in secs. $21,22,27$, and 28 of this township, through which glacial waters were discharged from the inner part of the morainic system. This glacial stream cut a channel about 15 feet below the general level of bordering parts of the outwash plain. The moraine is much more prominent north of this channel than south of it, knolls and sharp ridges 50 feet or more in height being present. Immediately west of Dows there is a sharp outlying ridge, about 4 miles long and less than a mile wide, that is separated from the main part of the morainic system by a plain of sandy outwash about half a mile wide. The main part passes east of Galt, but for about 2 miles west there are scattered knolls as much as 20 feet in height and a more undulating surface than farther west. The morainic belt follows up the

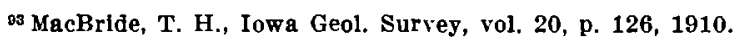


west side of the Iowa River past Elm and Cornelia Lakes, with a general width of about 2 miles. On passing the Great Western Railway it bears away from the Iowa River Valley, and a till plain 2 to 3 miles wide lies along its east border nearly to the north line of Wright County. The morainic belt surrounds Twin Sisters Lake and passes east of Olaf station, on the Minneapolis \& St. Louis Railroad. Its general width in northern Wright County is 2 to 3 miles. Its highest points are about 80 feet above Belmond but only 30 to 40 feet above the till plain on its outer border.

In southern Hancock County there is a single broad morainic belt 3 to 4 miles wide, east of which lies a gravelly outwash plain extending to the East Branch of the Iowa River. Its highest points are about 50 feet above the edge of the gravel plain, and many of its knolls are 20 to 30 feet or more in height.

About 3 miles south of the Chicago, Milwaukee, St. Paul \& Pacific Railway the morainic belt spreads out and splits into distinct ridges. The outer one runs northward nearly to the north side of the county, with a gravel plain 1 to 2 miles wide between it and the Iowa River. Its width also is 1 to 2 miles, and it has a strong expression, with sharp knolls and ridges 25 to 50 feet in height. The middle part of the morainic system runs northward to Eagle Lake, along the east side of the West Branch of the Iowa River, and has a width of about 3 miles. Near Eagle Lake it becomes separated into three narrow ridges, which die out in a plain within 2 to 3 miles to the north. Two of these ridges are east of the lake and the other one west of it. This west ridge follows the Minneapolis \& St. Louis Railroad nearly to Hayfield and is scarcely a quarter of a mile in width for a distance of 4 miles. The western part of the morainic system lies west of the West Branch of the Iowa River for several miles southeast from Britt, which stands at its inner border. It runs northwestward across Britt Township and then swings northeastward and runs past Crystal and Edward Lakes into Winnebago County. Its width in Britt Township is about 2 miles, but in Crystal Township it is 3 miles or more wide and forms the most prominent part of the morainic system. Spurs extend west from it 2 or 3 miles into Bingham and Orthell Townships. There is a narrow strip of sandy gravel outwash on its outer border in Britt and Crystal Townships. This gives place to a clayey plain farther out that occupies the greater part of the low area between the outer and inner members of this morainic system. Much of it is still in a marshy condition. The width of the morainic system and the plain between its members is 12 or 13 miles in the northern townships of Hancock County, but the morainic ridges occupy only about half this width.
In Winnebago County the main part of the Altamont morainic system lies west of Lime Creek. Immediately north of Forest City an outwash plain about 5 miles long and only $1 \frac{1}{2}$ miles wide heads in the western member of the morainic system and passes through a gap in the outer member to the Lime Creek Valley. Another member lies close to Lime Creek from this outwash plain northward into Minnesota, except from Scarville northward, where there is an outwash plain 1 to 3 miles wide between the moraine and the creek. The western or inner member is more prominent than the one east of it and forms the divide between the Cedar River and Des. Moines River drainage basins. It runs past Thompson, Coon Grove, and Lake Harmon and forms the Kiester Hills, in the southeastern part of Faribault County, Minn. Between these two main members there is a strongly undulating till plain with here and there clusters of sharp knolls. In places there is no clear line of separation between the outer and inner members, and where the morainic system passes into Minnesota they are completely united. The morainic: ridges with the intervening undulating land cover a: general width of about 10 miles in their course across. Winnebago County.

South of Grantsburg sublobe.-At the MinnesotaIowa line the main part of the Altamont morainic system is massed together in a single broad moraine of strong expression, whose highest points are known as the Kiester Hills, from the neighboring village of: Kiester. It is about 7 miles wide and covers nearly all of the southeast township of Faribault County and the western part of the southwest township of Freeborn County. An outwash plain of sandy gravel covers most of this township, and the moraine borders: it on the north as well as the west. At the place where the morainic belt makes a turn from a northward to. a northeastward course is the prominent range of kames that form the Kiester Hills, standing about 200 feet above the till plain on the north and west, or nearly 1,400 feet above sea level.

A prominent ridge of this morainic system is crossed by the Chicago, Rock Island \& Pacific Railroad immediately east of Conger and passes between Albert Lea and Manchester. It has an outwash plain of sandy gravel on its outer border from Albert Lea nearly to Clarks Grove. Near Ellendale it overlaps an earlier moraine, which may perhaps be a part of the Altamont morainic system. This outlying morainic ridge is a strong and continuous one from the State line at Emmons to Ellendale. It passes immediately east of Twin Lakes, Albert Lea, and Clark Grove, and is 2 to 4 miles in width. In places it is fully as strong as the ridge just outlined. South of the State line, however, it has a very irregular development. It is relatively weak for 3 miles south of the State line, but about 
2 miles north of Lake Mills, Iowa, there is a sharp range of hills which runs westward about 3 miles to Lime Creek. At its south edge there is a sharp ridge bearing some resemblance to an esker but containing till as well as gravel, which rises abruptly 40 to 60 feet above a featureless plain on the south. West of this plain, between Lake Mills and Lime Creek, there are a few knolls that may pertain to this belt, but it seems quite as probable that connection is made with the Altamont moraine near Scarville. On the whole it seems more probable that this moraine is a part of the Altamont morainic system than of the Bemis. It may be the equivalent and continuation of the eastern morainic ridge in Hancock County, Iowa. Glacial drainage from its outer border went down the Shellrock River and built up a plain of sandy gravel about 2 miles in width. The plain south of it in the vicinity of Lake Mills, Iowa, is covered with a deposit of pebbleless clay 2 to 6 feet or more thick, indicating $a$ ponding of water in that locality. In this connection it should be noted that in and around Albert Lea there is a deposit of lake clay up to a level some 30 feet above Lake Albert Lea. This clay seems to have been due to a drift barrier at the southeast end of the lake which was not cut away until the moraine that passes west of Albert Lea was formed. It is inferred from this deposit that the moraine which passes east of the city is but little older than the one to the west, and both are referable to the same morainic system. The ponding around Lake Mills, Iowa, is probably due to a drift barrier on Beaver Creek or at the southeast end of Rice Lake, in western Worth County, but neither locality was visited by the writer.

There are three morainic ridges in northwestern Freeborn County, Minn., that are combined with the Altamont morainic system in Waseca County. One that leads from Walters, in southeastern Faribault County, northeastward, passing just east of Alden and Hartland, has considerable strength, but the others are rather faint moraines, which die out in a plain near the line of Freeborn and Faribault Counties between Alden and Wells. It is probable that the moraines whose courses have just been outlined are the equivalents of the Gary and later moraines of southwestern Minnesota (p. 75) rather than of the Altamont, but they are completely merged with the Altamont in much of their course from southeastern Waseca County northward to the Minnesota Valley.

North of Grantsburg sublobe.-The equivalent moraines of the Grantsburg sublobe are discussed below (pp. 84-87) by Sardeson. It is probable that the second or Crow River morainic system in that sublobe may be correlated in a general way with the Altamont morainic system. As indicated in the discussion of the Bemis moraine (pp. 61-64), there is some uncertainty as to the correlation of moraines in the ciistrict north of the Grantsburg sublobe with those in the part of the Des Moines lobe to the south. However, there seems little question that the main morainic system in this district is the equivalent of the Altamont system of other parts of the Des Moines lobe. Whether certain moraines outside the main belt, such as the "Leaf Hills moraine," also fall in the Altamont system is a matter of uncertainty. On the inner or western border also, from Pope County northward, later moraines than the Altamont are closely associated with it.

One of the outlying moraines that should perhaps be included in the Altamont system leads from the gray-drift border in the vicinity of Richmond, in southern Stearns County, southwestward between Paynesville and Cedar Lake to the north border of Green Lake near New London, where it becomes united with the main morainic belt. Its outwash apron also seems to merge into that of the main morainic belt north of New London, with no apparent evidence of difference in age. This moraine has a much stronger expression than the Bemis moraine that leads northwestward from Richmond and is also stronger than the moraine along the gray-drift border southeastward from Richmond. Yet that moraine seems to form a natural continuation for the Altamont as well as the Bemis moraine, and it would be expected to have greater strength. The outer part of the moraine next to the outwash plain carries a larger amount of sand and gravel and has a sharper expression than the inner part, which grades into a till plain on the southeast.

The moraine just discussed seems to antedate the outer moraine of the Crow River morainic system of the Grantsburg sublobe, as that moraine is correlated with the main morainic belt of the Altamont system. Before the ice border began to recede from the outer noraine of the Crow River system it had melted back southward across northern Meeker County and taken the position of the main belt of the Altamont system. In the district it thus vacated there are drainage features that make this clear. A ponding of water took place in the part of the Crow River Valley directly above (west of) the outer moraine of the Crow River system, and laminated clay of considerable thickness was laid down in this lake. Its discharge was northward through Eden Valley, a well-defined valley passing just east of the village of Eden Valley, Meeker County, to the Sauk River near Richmond. On the korders of this lake area there are strips of sandy land, the clay being restricted to the deeper part of the basin. To the south, around Litchfield, is an extensive out. wash plain of sandy gravel, formed at the junction of the Grantsburg sublobe with the main ice lobe, and 
this plain drained northward across the ponded waters of the Crow River through Eden Valley to the Sauk River. The headwater part of the Crow River and also Eden Valley are bordered by a till plain standing above the level of the ponded waters and lying between the moraine just discussed and the main morainic belt of the Altamont system, as well as the outer moraine of the Crow River system of the Grantsburg sublobe. The extent of the till plain, the outwash plain, and the ponded district along the Crow River and their relations to the Grantsburg sublobe and the main ice lobe may be seen by reference to Plates 1 and 2.

The main morainic belt of the Altamont system is a conspicuous feature from its junction with the Crow River system of the Grantsburg sublobe, in southern Meeker County, northwestward across northcentral Kandayohi, northeastern Swift, and central Pope Counties. It is bordered on the northeast by one of the most conspicuous outwash plains in the State, 5 to 8 miles wide and over 40 miles long. The morainic belt for 2 to 4 miles back from the outwash i lain is of more gravelly constitution than in its inner cr western part. There is, however, a gravelly spur, part of which is known as Blue Mounds, running westward across the morainic belt in southern Pope County nearly to Lake Emily, and a group of prominent kames south of this spur near Langhei. The morainic belt is interrupted by a great depression southwest of Glenwood, in which Lake Minnewaska lies, about 200 feet below the level of the morainic crest on each side. Numerous lakes occupy pits of various sizes and depths all along this main morainic belt, not only in the section under discussion but for a long distance to the north, as shown on the general glacial map. These lakes, together with the prominent knolls and ridges of the morainic belt, give it a strength of expression exceeded at few other places in the State. Yet the height of the crest of the moraine above the outwash plain on its outer border is very moderate, generally but 25 to 50 feet. The variations of level within the moraine reach 100 feet and in places even 200 feet.

The main part of the Altamont morainic system runs from Pope County in a course west of north across western Douglas County into central Otter Tail County and there passes around the west end of Otter Tail Lake, beyond which its course is east of north into Becker County. A strip of gravelly outwash setting in east of Dalton and running northwest, east of Fergus Falls and Elizabeth, seems to lie ketween it and later moraines on the west. This line of separation is continued northward along the Pelican River to its source in Pelican Lake, and thence northeastward in a broader gravelly strip that termi- nates near Detroit. The morainic belt thus outlined has a strong expression, compared with the later moraines to the west, and might easily pass for the full representative of the Altamont morainic system. It is possible, however, that the "Leaf Hills moraine" of Upham, ${ }^{94}$ lying east of it in Douglas and Otter Tail Counties, should be included in this morainic system.

The "Leaf Hills moraine," as interpreted by the present writer, was developed by an eastward-facing ice lobe and is thus earlier than moraines to the west. In this interpretation it is not the ninth moraine, as numbered by Upham, but is at latest an early part of the second or Altamont morainic system. It may prove to be earlier than the Altamont system. If the outwash plain on the east is regarded as a dependency, formed at the same time, as it seems to be, the moraine includes a strip of sharp gravelly knolls that runs northwestward from southwestern Todd County across northeastern Douglas County. Its southward continuation may run through eastern Douglas County into connection with the main Altamont morainic belt near the line of Douglas and Pope Counties, but if so it lacks the strong expression which it exhibits to the north. Perhaps it connects also with the main morainic belt along a narrow but sharp morainic ridge that runs southwestward from Miltona between Lake Carlos and Lake Ida to Alexandria, its connection at the south being obscured somewhat by outwash from the main morainic belt. In southern Otter Tail County a till plain lies on its inner border near Effington. But in the township to the west is a strong spur, Leaf Mountain, developed where the moraine makes an abrupt turn from a northwest course to a course east of north. The Parkers Prairie outwash plain is widest opposite this bend. At the Leaf River the course of the moraine changes to west of north, and it continues with considerable strength to Pine Lake in northern Otter Tail County, passing immediately west of New York Mills. It seems to have its continuation northward into Becker County in a strong moraine running east of the Otter Tail River to Height of Land Lake, where it becomes merged with the main morainic belt. The general width of the "Leaf Hills moraine" is about 2 miles. It has scarcely one-third the average width of the main morainic belt, but in much of its course it is as prominent as the strongest part of the main belt, its crest being in places 100 to 150 feet or more above the bordering till plain on the west and nearly as much above the outwash plain on the east. There are parts of the Parkers Prairie outwash plain that nearly reach the 1,500 -foot contour, but parts of the moraine are above 1,600 feet, and a

94 Upham, Warren, Geology of Minnesota, vol. 2, pp. 549, 570-571. 1888. 
few points may exceed 1,700 feet. From its outer border there was strong drainage to the Mississippi, with valley trains down several of the tributaries, as well as an extensive outwash gravel plain along the morainic border. On the western or inner border the drainage now goes largely to Otter Tail River, of the Hudson Bay system. In part of its course the crest of the moraine forms the divide between the Hudson Bay and Mississippi drainage systems. As is common in moraines of strong relief, the drift is largely loose textured, with considerable gravel and sand interbedded.

The greater part of the strip of land between the "Leaf Hills moraine" and the main Altamont morainic belt is occupied by an outwash plain bordering the Altamont moraine, but from a locality near the line of Douglas and Otter Tail Counties northward to Richdale, in northeastern Otter Tail County, there is a narrow till plain 2 to 5 miles in width along the inner or western border of the "Leaf Hills moraine." In the vicinity of Otter Tail Lake the outwash plain is expanded to a width of about 15 miles, but its usual width is less than 5 miles. Besides Otter Tail Lake, which is about 12 miles in length, the outwash plain includes several lakes 3 to 6 miles long, as well as numerous smaller ones. These lakes appear to occupy places where detached masses of the ice sheet persisted during the general retreat of the ice border from the "Leaf Hills moraine" to the edge of the main Altamont moraine, and if this inference is correct the Altamont appears to have been a close successor of the "Leaf Hills moraine."

From central Becker County, where the "Leaf Hills moraine" and the main Altamont moraine come together, there is a prominent morainic belt that swings around to the east through northeastern Becker County and southern Clearwater County into Hubbard County, and this continues eastward in great strength across central Hubbard County to Leech Lake, in Cass County. In Hubbard County its width is about 15 miles. From the vicinity of Shell Lake, in Becker County, about to Tenmile Lake, in Cass County, it is bordered by a broad outwash plain of sandy gravel. The morainic belt consists of loosetextured drift, with much included sand and gravel, for several miles back from the outwash plain, but becomes more clayey toward its inner or northern border. There are numerous small lakes inclosed among the morainic knolls and ridges throughout its course from Becker County to Leech Lake, and that lake fills a great irregular depression in the morainic belt. In the outwash plain the lakes are much elongated, and some of them fill imperfectly drained parts of valleys that probably served as lines of glacial drainage across the outwash plain. A till plain several miles in width lies north of Leech Lake and north of this morainic belt from Leech Lake westward across northern Hubbard County and southern Clearwater County, its northern limits being at an outwash plain of sandy gravel that borders a later system of moraines, as indicated below (p. 109). A large part of this till plain is under cultivation, and settlements extend into the clayey part of the morainic belt to the south. But a large part of the morainic belt is still in forest. The outwash plain is largely under cultivation, and some of the oldest settlements in northern Minnesota were made on it. The ease of clearing the land and its level surface were the inducements to early settlement.

In Cass County, from Tenmile Lake eastward past Longville, this morainic system with gray drift overlaps the St. Croix system of red-drift moraines that comes up from the south, and in places it forms a relatively thin veneer over the red drift. But the gray drift forms the main part of the promontories that project into Leech Lake. The moraine of gray drift seems to extend westward outside the limit of the red-drift deposits within a few miles west of Leech Lake and there to have features entirely independent of these deposits.

For some reason not yet understood the great strength which the Altamont system displays all along its course from Leech Lake southward to the end of the Des Moines lobe in central Iowa is not maintained beyond this lake. There is a till plain of gray drift for about 20 miles east of Leech Lake, its eastern limits being near Cohasset and the village of Shovel Lake. East of this plain is the overridden Mille Lacs moraine of red drift, which runs northward from Hill City through the central part of Itasca County. This moraine carries only a thin veneer of the gray drift, which modifies the red-drift features but slightly. The gray drift has a marked extension southward from Hill City into the lowland bordering the Mississippi River in Aitkin County. It also, as already indicated (p. 64), has a great extension into the St. Louis River basin south of the Mesabi iron range.

Outwash from Altamont morainic system.-Vigorous discharge at the head of the Big Sioux River, in southwestern Roberts County, S. Dak., from the junction of the Dakota ice lobe with the Des Moines or Minnesota-Iowa lobe, spread out a gravelly outwash over an area of 25 or 30 square miles. Outwash material was probably carried far down the Big Sioux Valley from the Altamont morainic system as well as from the outlying Bemis moraine.

In Grant and Codington Counties there was more or: less ponding along the ice border while the Altamont morainic belt was being formed, but small areas of gravel are found in the vicinity of South Shore and 
between South Shore and Troy. In Deuel County, S. Dak., there is some gravelly outwash from this morainic belt north and east of Clear Lake, with drainage down Hidewood Creek through the Bemis moraine. Elsewhere in this county there seems to have been either ponding or a lack of free drainage on the ice border.

In southwestern Minnesota very little gravelly outwash is found on the border of this morainic system. There is some gravelly material along the Des Moines River below Currie, and also a small amount along the outer border of the morainic belt where it lies a few miles back from the Des Moines River in southwestern Cottonwood County.

In Dickinson County, Iowa, there is a conspicuous gravelly outwash deposit south of Lake Okoboji, near Milford, with discharge down the Little Sioux Valley. But with this exception outwash appears to be scanty along the west side and south end of the Des Moines lobe in Iowa. This meagerness seems remarkable, as the surface outside slopes away from the morainic belt, and there is now good drainage from it into the Raccoon River in Calhoun, Carroll, and Greene Counties. From the south end the Des Moines and Skunk Rivers and some of their tributaries lead directly away from the morainic belt, but their valleys show remarkably little outwash material. On the east side of the Des Moines lobe outwash of sandy gravel is conspicuous from northwestern Hardin County northward into Minnesota. It lies chiefly along the Iowa River but also borders Lime Creek, a tributary of the Cedar River.

In Freeborn County, Minn., there are conspicuous outwash plains of sandy gravel near Mansfield and north of Albert Lea. There was also outwash into the Shellrock Valley from the south end of Lake Albert Lea. There are outwash deposits of sandy gravel in southern Steele County, leading to the Straight River. In Rice County the only conspicuous outwash is at the Cannon River near Morristown. There was vigorous outwash into the Minnesota Valley near Shakopee from the outer part of the morainic system, and the outwash was abundant farther up as the ice edge retreated up the valley. There was vigorous outwash also into the Mississippi Valley from the vicinity of Minneapolis up to the Clearwater Valley. Some of the outwash material was laid down on the east side of the valley when the ice border stood on that side in the vicinity of Anoka, but most of it was laid down on the west side after the ice had vacated the valley. Outwash is very conspicuous from southern Stearns County north and northwestward into Otter Tail County and still farther north along Otter Tail River nearly to its source. Great outwash plains in eastern Becker County and southern Hubbard County also seem to have been largely formed in connection with the Altamont morainic system. Farther north outwash is not a conspicuous feature, and there appears to have been considerable ponding of water. This was due partly to the much lower altitude in the northern part of Minnesota at that time than at present. The northward differential uplift of that region is discussed in a later section.

\section{GARY MORAINE}

Extent.-The Gary moraine was named by Chamberlin ${ }^{95}$ from Gary, S. Dak. It is combined with the Altamont moraine in Roberts and Grant Counties, $\mathrm{S}$. Dak., the combined breadth being 6 to 8 miles, about half of which probably pertains to the Gary moraine. The villages of Marvin, Stockholm, and Strandburg appear to be on the Gary part. Its inner border is about 6 miles west of Sisseton and passes near Marvin, Twin Brooks, Labolt, and Revillo. The Gary moraine is lower on the northeast slope of the Coteau des Prairies than the Altamont. Its inner edge is about 1,400 to 1,500 feet above sea level, and the outer edge lies 200 to 300 feet higher. It crosses Deuel County, S. Dak., as a distinct moraine, separated from the Altamont moraine by a strip of undulating till about 2 miles wide. It passes into Minnesota immediately south of Gary, which is near its inner border.

This moraine is combined with the Altamont moraine in Yellow Medicine County and the northern part of Lincoln County, Minn. It becomes a distinct moraine about 3 miles north of Ivanhoe, where it also splits into two members with a narrow till plain separating them in northeastern Lincoln County. The two members with the included till plain occupy a strip about 6 miles wide. On entering Lyon County the members unite to form a single moraine 4 or 5 miles wide. The outer border is at Russell and the inner border about 2 miles southwest of Lynd. The moraine is again double from the vicinity of the Great Northern Railway southeastward to Tracy, the outer member being about 2 miles and the inner member $1 \frac{1}{2}$ miles wide. Near Tracy the moraine splits up into several distinct, rather low ridges, each only about a mile wide. The outermost ridge is at the county line 2 miles south of Tracy; the innermost one is about as far north of Tracy. There are four and in places five ridges in southeastern Lyon County and the adjacent parts of Murray and Redwood Counties. The several members unite in a single belt on the east side of Plum Creek, in northeastern Murray County, and this belt runs southeastward in Cottonwood County to the quartzite ridge between Storden and Jeffers, maintaining a width of about 3 miles. The

96 Chamberlin, T. C. Terminal moraine of second glacial epoch; U. S. Geol. Survey Third Ann. Rept., pp. 378, 388, 393, 1883. 
QUATERNARY GEOLOGY OF MINNESOTA AND PARTS OF ADJACENT STATES

moraine then takes an abrupt turn southward, and an inner member, which probably was developed directly after the outer and main member, sets in at the quartzite ridge, north of Jeffers, and leads southward past Delft. This moraine and the outer one become united between Delft and Bingham Lake, but a still later moraine branches off near Delft and runs southeastward across southeastern Cottonwood, northeastern Jackson, and southwestern Martin Counties. This seems to belong to the Gary system, although it is separated from the main morainic ridge by an interval of 4 to 6 miles in much of its course in these counties. The main member passes southward from Delft, crosses the county line directly east of Windom, and follows the east bluff of the Des Moines River southward into Iowa. Its width is only 1 to 2 miles from Windom to the State line. The moraine lying east of it has a general width of about a mile. The combined width. of the moraines is therefore no greater than the usual width of the Gary moraine, where it is not split up into separate members.

The Gary moraine reaches an altitude of 1,600 feet at the South Dakota line and maintains a similar altitude along its outer border across Lincoln County, Minn. In Lyon County it gradually decreases in altitude to the southeast and is not far from 1,500 feet on its outer border from Russell southeastward past Garvin into Murray County. The highest parts of the moraine are between 1,400 and 1,500 feet above sea level in northeastern Murray County and northwestern Cottonwood County. The moraine is slightly above 1,500 feet for a short distance at the place where it turns southward between Storden and Jeffers. From this point southward into Iowa the crest of the moraine is at 1,400 to 1,500 feet. The inner member is slightly less than 1,400 feet above sea level but generally above 1,300 feet.

The course of the Gary moraine in Iowa has not been determined. At the State line it lies east of the Des Moines River, but it probably passes to the west side within a few miles farther south and may be combined with the Altamont moraine in part of its course on the west side and at the end of the Des Moines lobe, for it appears to be combined with that moraine on the east side of the lobe.

The Gary morainic belt probably embraces the inner members of the series of moraines in western Freeborn, eastern Waseca, and eastern Le Sueur Counties, Minn. It probably wraps around if it does not include part of the Kiester Hills, in southeastern Faribault County. In Scott, Carver, and Wright Counties it probably includes one or two of the inner members of the prominent system of moraines that lies on the northeast border of the great plain drained by the Minnesota River. It probably includes the later mem- bers of the series of moraines at the base of the Grantsburg lobe (Delano and Montrose moraines, pp. 85-86). In Meeker, Kandiyohi, Swift, and Pope Counties it forms the inner part of the great morainic system northeast of the great plain that borders the Minnesota River. In Douglas County later moraines are crowded against its inner border, and in Otter Tail, Becker, and Clearwater Counties it is in close association with later moraines, as well as with the Altamont moraine. It probably forms the inner part of the great morainic system in Hubbard County and on the borders of Leech Lake in Cass County. To what extent it is represented in the veneer of gray drift on the red-drift moraines of Itasca County is not known, nor are its course and limits in Koochiching County. It probably traverses each of these counties.

Topography.-The topography of the Gary moraine in South Dakota is, on the whole, less rugged than that of the Altamont moraine, though many of its knolls reach a height of 30 to 40 feet. The slopes, originally steep, are greatly cut up by deep ravines of the postglacial drainage.

In southwestern Minnesota the moraine has knolls ranging from 20 to 50 feet or more in height, many of them with steep slopes. It is-in striking contrast to the very smooth till plain on its inner or northeast border. The knolls are generally without definite system in arrangement, but in places there is a succession ci nearly parallel ridges trending in the general direction of the morainic belt. Some of these ridges are separated by narrow intervening plains, but others are crowded against one another and present the appearance of a series of ribs running transverse to the slope of the Coteau.

In Iowa and southeastern Minnesota the knolls are commonly but 20 to 30 feet or less in height. There is, however, in southern Le Sueur County, Minn., a range of morainic hills of greater prominence, which extends as a spur several miles farther west than neighboring parts of the moraine. Some of the morainic knolls near Elysian, Minn., are 75 feet high. Upham ${ }^{98}$ regarded this belt of hills as a later moraine than the one leading south from it and gave it the name "Elysian." But in the present writer's opinion it is merely a spur formed in a recess in the ice border. Upham was able to trace it westward only to the vicinity of Lake Washington, several miles east of the Minnesota River. A similar spur in Carver County near Waconia was also interpreted by Upham ${ }^{97}$ to be a moraine later than the moraine leading south from it and was named the "Waconia " moraine. It extends southwestward from Waconia about to Norwood, but

Upham, Warren, Geology of Minnesota, vol. 1, pp. 461, 581, 1884. ${ }^{n}$ Idem, vol. 1, p. 621, 1884 ; vol. 2, p. 128, 1888 . 
there ends abruptly. It probably marks a recess in the ice border. Its knolls are of similar prominence to those in neighboring parts of the moraine to the north and south, being 25 to 30 feet in height, with a few still higher.

The part of the great morainic belt which the writer is inclined to correlate with the Gary moraine has a strong expression throughout its course from the Minnesota Valley northwest, north, and east to Leech Lake. It has numerous knolls 25 to 50 feet high, and a few 75 feet or more. It is strikingly in contrast with the till plain on its inner border as far as Swift County, but from that region to Leech Lake there are either strongly undulating till plains or later moraines on the inner border. The Gary moraine is banked against the inner border of the strong Altamont moraine throughout nearly all its extent on the east side of the area cccupied by the ice lobe in Minnesota. The only important exception is in the Grantsburg sublobe, where its constituent ridges are separated from one another and from the outlying Altamont morainic ridges by narrow strips of gently undulating till plain. Northward from Leech Lake the morainic features are ill defined, and definite morainic belts are not developed. Moraines of red drift were here overridden by the ice that carried the gray dirift, and they have a much stronger expression than any of the gray-drift features.

Structure of the drift.-In most of its course across eastern South Dakota and southwestern Minnesota the Gary moraine consists of clayey till, thickly set with stones of all sizes. The only place noted where it is conspicuously gravelly is in the outer member in northeastern Lincoln County, Minn. It is there made up in part of gravelly knolls, but some of the knolls are composed of clayey till. The character of the moraine in Iowa has not been determined.

On the east side of the Des Moines lobe in southeastern Minnesota the moraine consists mainly of clayey till. In the Kiester Hills, in the southeastern part of Faribault County, there is some gravelly drift which probably pertains to this morainic belt. A few gravelly knolls were noted southeast of Otisco, in eastern Waseca County. There are also gravelly knolls on the borders of Freeborn Lake, in western Freeborn County.

Near the west base of the Grantsburg sublobe, in eastern Meeker County, there is a strip of gravelly moraine extending for several miles northeast and southwest from Darwin. It fronts on the outwash plain which fills the reentrant between this sublobe and the part of the main lobe to the northwest and on which the city of Litchfield stands. Northwest of this junction the main lobe is characterized by clayey till in its course across Meeker, Kandiyohi,
Swift, and Pope Counties, the principal exception noted being a group of kames known as the Blue Mounds, in southern Pope County. Gravel knolls are interspersed with knolls of till in the rugged morainic areas of Otter Tail and Becker Counties but are more rare farther northeast in Clearwater and Hubbard Counties.

Outwash plains.-In the South Dakota portion of the Gary moraine and in much of its course in southwestern Minnesota it stands on the rather steep northeast slope of the Coteau des Prairies, in a topographic situation unfavorable for the spreading of outwash Inaterial on its border. In Minnesota the northernmost notable development of outwash gravel is in southern Cottonwood County, north of Windom. Glacial drainage led southward past Windom to the Des Moines River and followed down that valley into Iowa. There is a slight amount of sandy outwash outside one of the late members of the Gary system along the East Fork of the Des Moines River in southwestern Martin County.

The part of the morainic belt in Iowa has not been traced in detail nor examined critically as to outwash conditions. Some gravelly outwash in the vicinity of Crystal Lake, in northern Hancock County, borders a moraine that is tentatively referred to the Gary system.

In southeastern Minnesota there seems to be no conspicuous outwash connected with the Gary morainic belt south of the Minnesota Valley. Here there is a conspicuous deposit of outwash gravel in the vicinity of Carver, which was discussed by Upham ${ }^{88}$ as follows:

Another observation which seems to give the same testimony and to show that the modified drift forming high terraces and plains in this valley was deposited during the recession of the ice sheet is presented in the notably uneven surface of the broad part of the terrace of this valley drift in Carver County between Carver and Bevens Creeks. On this tract, composed, below the soil, of stratified gravel and sand, extending about 2 miles in width and elevated 125 feet above the river, are frequent depressions from 10 to 30 rods in diameter and $\mathbf{1 5}$ to 40 feet in depth below the general level, often inclosed without outlet, and some of them containing lakelets and sloughs. Such hollows have not been seen elsewhere in my explorations of these terraces along the Minnesota Valley, which instead have generally a smoothly level contour. Their origin must apparently be referred to sedimentation while masses of ice occupied the places of these bowl-like depressions.

Near Montrose, in eastern Wright County, there is an outwash gravel plain covering several square miles that seems to be a dependency of the Montrose moraine, a member of the Crow River morainic system. Still larger outwash plains near Monticello and near Annandale are similarly related to the Loretto moraine of the Grantsburg sublobe, which may be cor-

${ }^{\text {98 }}$ Upham, Warren, Geology of Minnesota, vol. 2, p. 133, 1888. 
QUATERNARY GEOLOGY OF MINNESOTA AND PARTS OF ADJACENT STATES

related with the outer part of the Gary system. There were ponded waters in northeastern Meeker County in the drainage basin of the North Fork of the Crow River. Lake clay is found in the deeper part of this ponded area, and sand on its shallow borders. South of this ponded area, in the vicinity of Litchfield, is an extensive plain of sandy gravel outwash, a little higher than the ponded area just noted but grading into it at the north. Near Atwaier is another place where outwash gravel borders the moraine. The Gary morainic belt is so closely merged with the Altamont farther north that it is difficult to draw the line of separation. Under such conditions outwash is rare and inconspicuous.

\section{GRANTSBURG SUBLOBE OF WISCONSIN GRAY DRIFT}

By Freblerick W. Sardeson

\section{GENERAL RELATIONS}

During the Wisconsin stage of glaciation, at the time when the western or Keewatin sheet of ice crossed western and southern Minnesota and the eastern part of the Dakotas in a southward to southeastward course and formed the Des Moines glacial lobe in northern Iowa, a sublobe turned northeastward from it, from south-central Minnesota, and extended across the St. Croix Valley to the vicinity of Grantsburg, Wis., as long since recognized and discussed by N. H. Winchell and Warren Upham. ${ }^{98}$

The Grantsburg sublobe covered the present course of the St. Croix River for about 40 miles, from the mouth of the Snake River to Osceola, Wis., and the present course of the Mississippi for 60 miles, from Clearwater to St. Paul. This sublobe diverged at nearly a right angle from the main or Des Moines lobe. The position of the point of deflection of the west edge of the sublobe at its culmination is shown by the distribution of its drift deposits to have been west of the Mississippi, near Kimball Prairie, in Stearns County. The east side of the base of the sublobe was south of the Minnesota River, near Lakeville, in Dakota County. At its maximum extension this sublobe covered an area 70 miles wide and 80 miles long, or, if we include the area covered by it in Wright County, where it merged into the main lobe, it was 100 miles long. The entire area covered by gray Keewatin drift northeastward from a line drawn from Kimball Prairie to Hutchinson, Belle Plaine, and Lakeville is described as the district of the Grantsburg sublobe. The Patrician red drift of the Wisconsin stage is present beneath the gray drift about as far southwest as this line.

Geology of Minnesota, vol. 2, pp. 254-256, 409-415, 439, 622, 625, 642, 1888. See also Winchell, N. H., Minnesota Geol. Survey Fifth Ann. Rept., pp. 156-174, 1877 ; Sixth Ann. Rept., pp. 84-87, 1878.
The ground over which the Grantsburg sublobe advanced is relatively low. Along the axis of the sublobe, from Anoka, on the Mississippi River, through North Branch to the St. Croix River, the altitude is not far from 900 feet above sea level. The margin of the ice spread out so as to rest on ground that is about 1,000 feet above sea level. Having overridden the great St. Croix morainic system of the Patrician drift sheet before crossing the line of the present Mississippi River, the Grantsburg sublobe spread thence easily northeastward over an intermorainic plain of the Patrician red drift. In that advance it encountered neither bare-rock ridges nor terminal moraines, except near its margin.

The drift deposited by the ice of the Grantsburg sublobe is the characteristic young gray Keewatin drift of the late Wisconsin substage of glaciation. It is generally a thin deposit, except within the later moraines to the south of the Mississippi Valley. In the development of the outer system of terminal moraines of the sublobe the red drift was frequently thrust up into knolls and ridges and the gray drift mixed in and spread over it. Intermixture of red till and gray till is not extensive, but the gravelly or sandy red outwash deposits where overridden by the gray drift were commonly mixed with it to such a degree as to make the till sandy, where otherwise it would be clayey. This occurred in the ground moraine as well as in terminal moraines of the Grantsburg sublobe.

The deposits of the area covered by the Grantsburg sublobe are in genetic order as follows: The extramorainic till sheet; the first or Rush Lake morainic system; the second or Crow River morainic system; and the dune sands. The dune sands were not derived directly from the ice lobe but were distributed by the wind soon after the ice had melted.

\section{EXTRAMORAINIC TILI SHEET}

Outside the first strong moraine on the north side of the Grantsburg sublobe there is a thin sheet of young gray till overlying the red Wisconsin drift. Its cuter border is in places marked by a slightly ridged and hummocky belt. Near Clearwater, in Stearns County, it covers parts of secs. 28, 29, 31, 32, and 33, T. 123 N., R. $27^{\prime}$ W., and part of sec. 6, T. 122 N., R. 27 W. This tract is an overridden part of a red-drift outwash plain. Its surface is undulating and has a stony clay soil and sandy to stony till subsoil. This till is only a few feet thick and is underlain by assorted sand and gravel of the red drift. The continuation of this till sheet extends across Sherburne County but is concealed to a great degree by outwash and dune sand. It emerges from under the dune sand near Princeton. For 25 miles, from the locality near 
Princeton to Braham, there is a narrow strip of clayey till about 3 miles wide. Along its outer or north edge the slightly ridged border, less than a mile wide, runs from the West Rum River 3 miles above Princeton to Braham. It consists of heavy clay till but has an undulating surface. Between the West Rum and Rum Rivers this drift comprises 2 to 6 feet of gray till, leached to a brown color, overlying crumpled laminated red silt of a glacial lake bed. Also from a point 2 miles east of Braham westward to Rice Lake there is a thin sheet of heavy clay till over crumpled beds of red sand and gravel. Between the Rum River and Rice Lake the surface is high and moderately rolling, and a brown or gray till overlies red till. The ground moraine, as well as this ridged border, consists in the main of clayey till, but a small area in secs. 12 and 13 , T. 36 N., R. 26 W., has a few feet of sandy gray till over red gravelly outwash.

The extramorainic till sheet is cut off near the northeast corner of Isanti County by strong moraines. It appears again east of the St. Croix River at Grantsburg and also at Osceola, Wis. On the southeast side of the Grantsburg sublobe, from the St. Croix River to St. Paul, the border of the young gray drift lies upon the inner part of the red drift of the St. Croix morainic system and is so thin as to have little topographic effect. The surface there was already strongly rolling before it was overridden by the Keewatin ice sheet and was but slightly modified by the later glaciation.

\section{THE FIRST OR RUSH IAKE MORAINIC SYSTEM}

The first morainic system comprises four moraines which are merged into one complex moraine at the reentrant on each side at the base of the sublobe but spread apart northeastward toward the end of the lobe. The course and relations of the moraines are largely obscured by a deposit of dune sand over them. There is also some confusion where red-drift moraines are overridden by the gray drift. The morainic system is best displayed near Rush Lake, in northern Chisago County, and is therefore called the Rush Lake morainic system. The several moraines are here named the Pine City, Cambridge, Isanti, and Harris moraines, in the order of their development.

Where the Grantsburg sublobe separates from the main lobe near Kimball Prairie, this morainic system is not only merged into a single great moraine but partly overridden by a moraine of the second or Crow River system. Overriding of this sort occurs also at the other reentrant, south of the Minnesota River. The system appears to become divided into moraines just where it turns into the sublobe.

Pine City moraine.-The course of Pine City moraine (pl. 2) appears to be along the south side of
Lake Louisa at South Haven, in Wright County, but is nearly covered by outwash gravel. A small area not so covered appears in secs. 10 and 16, T. $121 \mathrm{~N}$., R. 28 W., near South Haven. Three small spots of it are also exposed 1 to 2 miles north of the town, in secs. 4,8 , and 9 . Its course is thence northeastward on the north side of Clearwater Lake and the Clearwater River through Stearns County. A small prominence surrounded by outwash appears in secs. 20 and 21, T. 122 N., R. 27 W. In Sherburne County two knolls rising above the outwash seem referable to this moraine. One is on the line of secs. 26 and 35, T. $35 \mathrm{~N}$., R. $30 \mathrm{~W}$, and the other, known as Blue Hill, is in the northwestern part of sec. $28, T$. $35 \mathrm{~N}$., R. $27 \mathrm{~W}$. The moraine seems to run northward from Clearwater to the Elk River eastward to Blue Hill and southward to Crown, in secs. 4 and 9 , T. 34 N., R. $25 \mathrm{~W}$., where it agains turns northeastward. This part, however, is all covered with dune sand except a small area near Crown.

North of the Rum River the moraine is mostly free from the cover of dune sand. It emerges, 3 miles wide, in the center of T. $36 \mathrm{~N}$., R. $24 \mathrm{~W}$., and spreads to $?$ width of 5 miles as a knolly belt trending northeastward but narrows to only 2 miles in the center of T. 37 N., R. 23 W. Thence it runs east and north as a strongly ridged and knolly belt about 2 miles wide, forming a reentrant in passing around a high ridge in the northeast corner of Isanti County. It continues northeastward to the Snake River at Pine City and follows the south side of the Snake Valley to the St. Croix Valley in sec. 3, T. 38 N., R. 20 W.

At the apex of the sublobe, on the east side of the St. Croix Valley and for many miles south, down to Osceola. this moraine and the next two in order have been cut away to some extent by the glacial St. Croix River when it served as the outlet for the glacial Lake Duluth. Parts of the moraines are still present above Taylors Falls. In secs. 27, 28, and 34, T. 34 N., R. $19 \mathrm{~W}$., a group of morainic hills combines the features of an overridden red-drift moraine with knolls of the gray drift. For 4 miles in the vicinity of Taylors Falls the morainic knolls are built around rock prominences.

Between Taylors Falls and White Bear Lake, near St. Paul, the three moraines of gray drift appear to be merged into a single belt. They rode over the inner part of the St. Croix morainic system of the Patrician ice sheet and modified it to only a slight degree. West of White Bear Lake the moraines of gray drift are not so closely united but are not distinct, as they are riding over the red-drift moraines, whose features are much more prominent than those of the gray drift. The Pine City moraine here forms the border of the young gray drift and is about 2 
miles wide as it passes southwestward from White Bear Lake between Phalen and Gervais Lakes. It runs to Owasso Lake and thence west on the south side of the Duluth branch of the Northern Pacific Railway to the Mississippi River. ${ }^{1}$ This moraine passes the southwest corner of Ramsey County and enters Dakota County near Mendota. The Minnesota Valley makes a break in it. In the vicinity of Savage, near the Scott County line, the course of the moraine changes to southward. It there unites with or is overridden by later moraines of the gray drift.

Cambridge moraine.-The Cambridge moraine (pl. 2) appears to have been buried under outwash gravel from Twin Lake, south of South Haven, to Sugar Lake, in northwestern Wright County. But between Sugar and Lime Lakes and to the north a morainic tract remains exposed that is 3 miles wide and 5 miles long. It appears to show the turning of the moraine from a northeasterly to a northerly course. In Sherburne County, north of Becker, a tract 3 miles square is morainic, but the ground west and south of it is covered by outwash gravel, and that east and north by dune sand. The moraine emerges next from under the dune sand on the east side of the county, in secs. 25,26 , and 34 , T. 35 N., R. $26 \mathrm{~W}$. It is there just at the turn to a southerly course. The moraine then lies nearly 3 miles wide along the Sherburne and Isanti County line. It is high and strongly ridged. Its southerly deflection and some of its relief is due to the crossing of an older ridge which runs along the east side of Sherburne County from a point near Princeton to a point east of the village of Elk River. The moraine turns to a northeasterly course in the northwest corner of Anoka County. It becomes narrow near the borders of Anoka and Isanti Counties and disappears under a subsequent outwash plain, 4 miles east of the Sherburne County line. North of St. Francis the course of the moraine under the dune sand can be seen by the surface altitude, running northeastward parallel to the Rum River Valley. About 100 acres of till is exposed in secs. 9 and 16, T. 34 N., R. $24 \mathrm{~W}$. The dune-covered moraine crosses the Rum Valley below Cambridge. Till appears at the surface 2 miles east of Cambridge, and the moraine maintains a width of 2 miles from that place up to Rush Lake. It spreads at the lake, part of it skirting the west shore and part going between the two arms of the lake. North of the lake it is united again. Where the moraines cross into Pine County the Cambridge moraine partly overrides the Pine City moraine. In Pine County the Cambridge moraine is about 2 miles wide and curves eastward and then southeastward to the county boundary. It is cut off by the St. Croix glacial river valley on the county line.

1 See U. S. Geol. Survey Geol. Atlas, Minneapolis-St. Paul folio (No. 201), p. 8, 1916 .
The St. Croix glacial river destroyed the Cambridge noraine for many miles, but its course, like that of the Pine City moraine, was probably southeastward to Taylors Falls. It merged with the Pine City moraine from the St. Croix Valley to White Bear Lake. Thence it appears to run from the west side of Bald Eagle Lake southwestward to Vadnais Lake and westward past New Brighton to the glacial Mississippi Valley at the line of Anoka and Hennepin Counties. It runs through the northwestern part of Minneapolis and St. Louis Park, and, crossing the southwest corner of the city around Harriet Lake, it disappears under outwash. Its continuation south of the Minnesota Valley is in a morainic complex along the line of Dakota and Scott Counties.

Isanti moraine.-The Isanti moraine (pl. 2) has not been recognized in the complex morainic tracts in Wright County, south of the Mississippi Valley, nor in Sherburne County except in the southeast corner. It is a weaker moraine than the Pine City and Cambridge moraines, being usually only a quarter to half a mile wide. Two miles east of the village of Elk River, in sec. 36, T. 33 N., R. 26 W., this moraine comes to view as if overridden up to that place by later moraines. It runs northeastward in T. $35 \mathrm{~N}$., R. $25 \mathrm{~W}$., through secs. 30,20 , and 16 , and then north to Nigger Lake. It then runs northeast through secs. 9. 4, 3, and 2, T. 33 N., R. 25 W., and into secs. 34 and 35 , T. 34 N., R. 25 W., where it disappears under the cutwash gravel in the same way as the Cambridge moraine does north of it. The Isanti moraine is covered by dune sand on the east side of the Rum River from St. Francis to old Isanti village, 11/2 miles north of the present town. It appears as a till area on the line of secs. 16 and 21 , T. 35 N., R. 23 W., and runs across secs. 15, 11, and 1 and adjacent sec. 36, T. $36 \mathrm{~N}$, R. 23 W., and sec. 30, T. 36 N., R. 22 W. It then joins the Cambridge moraine and is closely parallel to it in Pine County.

On the east side of the sublobe the Isanti moraine is not distinguished from those formed earlier, although from the north end of Bald Eagle Lake it probably runs north of Pleasant Lake and around the north side of Mounds View to New Brighton.

Harris moraine.-The Harris moraine (pl. 2) is not distinguished in Wright County, but it may there form a part of what has been described as the Cambridge moraine. In Sherburne County it is a distinct feature. It is exposed in a narrow strip a quarter of a mile wide and 2 miles long running west from the north end of Eagle Lake, which is merely a section across the moraine between the part that has been buried under outwash gravel of the glacial Mississippi River and a part to the north covered by dune sand. The moraine emerges at Zimmerman from the edge of the dune-sand area. It is here interrupted by Fre- 
mont Lake and the former southward extension of that lake, but enough remains to show that it is just turning from an easterly to a southerly course at that place. This southerly deflection seems due to the high altitude along the east side of the county. The moraine runs a mile wide along the west slope of this high land in secs. $15,22,27$, and 34, T. 34 N., R. 26 W. It spreads out on the crest of the high land southward. Its east border runs through the middle of secs. 2 and 12 , the west side of secs. 13 and 24 , and the east side of sec. 26. A later moraine, the Anoka moraine of the Crow River system, lies against the Harris moraine along the west side of secs. $3,10,15$, and 22 and overrides and cuts it off in secs. 26 and 27 . The Harris moraine appears to turn sharply east, however, at Elk River village, and then northeast in Anoka County. In this part the outer border runs from the southeast corner of sec. 31 to the southeast corner of sec. 21 , T. 33 N., R. 25 W., but is interrupted by outwash plains in both directions beyond these points. The outwash leaves exposed a triangular morainic area whose south boundary runs from the north side of sec. 6 to the center of sec. 2 , T. 32 N., R. 25 W., and whose east boundary runs from that point to the southeast corner of sec. 2 , T. 33 N., R. 25 W.

The course of the moraine beneath the dune sand east of the Rum River is very probably from a point south of St. Francis past Bethel to sec. 4, T. 34 N., R. $23 \mathrm{~W}$., southeast of Isanti, where the moraine emerges. It is a mile wide there and runs north from the south side of sec. 33 , T. 35 N., R. 23 W. It then turns eastward into sec. 27 and runs across secs. 23 and 26 to sec. 21, T. 35 N., R. 22 W. There it turns rorthward and spreads, crossing secs. 15 and 16, 10 and 11 , and 2,3 , and the eastern part of 4 . In T. 36 N., R. 22 W., it is about a mile wide, from secs. 34 and 35 northward to secs. 2 and 3 . The moraine extends across sec. 35, T. 37 N., R. 22 W., and projects into sec. 26 to the swamp at the east end of Rush Lake. It then turns south into sec. 36. A part of the moraine runs eastward across the northern part of sec. 12, T. 36 N., R. $22 \mathrm{~W}$. This part is largely interrupted by an outwash deposit. The moraine as a whole crosses secs. 5 and 8 , T. 36 N., R. 21 W., and runs southeastward to sec. 15, where it is cut off by the St. Croix Valley. The glacial St. Croix River cut away the moraine between Harris and Sunrise, and the moraine is concealed by dune sand for 4 miles south of Sunrise. But at Kost village only a few dunes are scattered on its western slope. It is about $11 / 2$ miles wide. Its eastern or outer border runs south through sec. 28 , T. 36 N., R. 20 W., to the north end of Sunrise Lake. From the south end of the lake it runs southwestward past the township corners nearly to Wyoming. The inner border is followed by the Sunrise River from the locality near Wyoming to Kost. The moraine is cov- ered by dune sand from the Wyoming locality southward into the northwest corner of Washington County and through Anoka County along the west and north side of Rice Creek to Fridley, on the east bluff of the Mississippi River.

West of the river the moraine is interrupted for a few miles by an outwash plain, but it emerges between Osseo and Fish Lake and runs in a strip nearly 3 miles wide in a course south of east, passing east of Medicine Lake and west of St. Louis Park through Hopkins to the Minnesota Valley. South of this valley it is merged in the great morainic complex.

Topography.-The moraines of the Rush Lake system have generally a moderately rolling surface. At reentrant angles they show exceptional roughness. Thus northeast of Elk River village the Cambridge and Harris moraines have strongly rolling surfaces. East of Braham the Pine City and Cambridge moraines have prominent knolls and strong parallel ridges. For some reason, on the other hand, where these moraines have reached their northern limit and made an eastward or southeastward turn they become weaker or have gentler undulation. The Cambridge moraine in particular looks as if that part of it were water-laid.

In places where the moraines of young gray drift override the red-drift moraines the knolls and ridges are exceptionally prominent, yet they are less rough than the surface of the same red moraines where they have not been overridden. Where ground moraine of gray drift lies over terminal moraines of red drift the surface commonly has as strong relief as is usually presented by the terminal moraines of the young gray drift, or even stronger. But at the same time such ground moraine lacks the detail of hummocks and basins and the variable constitution of the terminal moraines. However, gray ground moraine over the red terminal moraines is easily mistaken for gray terminal moraine.

Composition.-In Stearns and Wright Counties the small areas that pertain to moraines of the Rush Lake system are composed of clayey till. Those in western Sherburne County are the same except that in spots sand is scattered over the till. In eastern Sherburne County nearly all these moraines are made up of sandy till, probably owing to the introduction into the till sheet of gravel and sand from overridden outwash deposits. The Pine City moraine shows many changes from clayey to sandy till in Isanti County. There is some clayey till at Crown, but north and east of that place the moraine is sandy or gravelly. From the Rum River to the St. Croix the moraine consists of clayey till except for a more sandy strip along Stanchfield Creek.

The Cambridge moraine consists of sandy till in Sherburne County and for about a mile east of the 
county boundary. Thence to the Rum River this moraine and also the Isanti are mainly clay till. The Harris moraine has sandy till in northwestern Anoka County, except about 2 square miles of clay till in secs. 32 and 33 , T. 34 N., R. 25 W., and secs. 5 and 4 , T. 33 N., R. $25 \mathrm{~W}$. The Cambridge, Isanti, and Harris moraines from the country east of the Rum River northward are nearly all loose-textured sandy till almost to Rush Lake. Around Rush Lake and from that area to the St. Croix Valley they are nearly all clayey till. The moraine east of the Sunrise River is mostly clayey till, and such till prevails in the morainic tracts around Taylors Falls and thence southwestward to Forest Lake and White Bear Lake. The moraines of this system also consist prevailingly of clayey till from White Bear Lake southwestward to the Minnesota Valley. In several places, however, small areas of outwash of the red drift have been overridden and in such places the overlying till is of a sandy nature.

Glacial striae.-Glacial striae on the Keewenawan rocks near Taylors Falls that seem referable to the Keewatin ice sheet show an eastward bearing. At Minneapolis also the striae of the latest movement bear eastward.

Associated outwash and glacial drainage.-The original extent of the outwash pertaining to the Grantsburg sublobe is fairly well shown, for the dune sand seldom lodged on outwash plains. The outwash deposits associated with the Rush Lake morainic system are of greatest extent near the reentrants that mark the divergence of the sublobe from the main lobe. On the northwest side in Wright and Stearns Counties there is outwash from several moraines of the system all thrown together. This outwash extends from Kimball around the border of young gray drift to Clearwater and north across the Mississippi River into Sherburne County. The direction of outwash was not only out, or north, from the ice border, but was also eastward along it, as shown by the slope of the surface. From Kimball, 1,138 feet above sea level, the outwash descends to 1,016 feet at Cable, in Sherburne County. Successive positions of the ice border during the deposition are shown by descents from one plain to another. Thus the plain at Kimball, north of the Clearwater River, is about 36 feet higher than that at South Haven, south of the river. Correspondingly Cable (altitude, 1,016 feet) and Haven (1,014 feet) are higher than Clear Lake (997 feet).

Some outwash from the Crow River morainic system lies adjacent to and more or less mingled with that of the Rush Lake system. That belonging to the Rush Lake system begins about 3 miles northwest of Kimball and lies north of a line running to that village and to the west end of Lake Louisa. It includes also the outwash east and south of the Clearwater River to the north side of Twin, Sylvia, John, Pleasant, and Sugar Lakes and east to Fish Lake below Clearwater. North and west of Clearwater it extends from the river 3 miles south of Clear Lake northeast, north, and west to the gray-drift border.

Besides the basins of lakes and ponds which lie in this area of outwash gravel, part of the surface has the unusual feature of being distinctly rolling. Between Lake Louisa and Twin Lakes the surface is rolling, and also. from South Haven north of Clearwater Lake nearly to Clearwater village and southeastward from that tract between Sugar and Clearwater Lakes. This rolling outwash appears to lie upon moraines and to veneer the rolling surface which they presented. There are in this area basins which are attributed to the melting away of cakes of ice buried either in the moraines or in the outwash itself.

The outwash consists generally of medium to fine gravel and sand. Drainage that produced this outwash in the reentrant under discussion came from the ice border in several or many places between Kimball and the valley of the Elk River. The general slope of the plain was caused by the direction of drainage, which was eastward. The first drainage course was along the line of swamps that leads from the area north of Fairhaven by Plum Creek to Clearwater. Later the course of the Clearwater River was followed, and thence along the present course of the Mississippi, but in reverse direction, to Sauk Rapids. Drainage from Cold Spring down the Sauk River also reached Sauk Rapids. The flow was thence eastward to the Elk River through a channel that passes east of East St. Cloud. The border of the young gray drift was followed eastward from the Elk River to the Rum River near Princeton, through Sevenmile Swamp to the Groundhouse River, and thence to the Snake River and down its valley to the St. Croix River.

There is an outwash deposit on the Rum River in the vicinity of St. Francis that seems to connect with the Harris moraine. It is about 11 miles long and 1 to 3 miles wide. The northern part of it is a low, flat sandy plain, which ends near the Pine City moraine. The gravel is somewhat coarser in the southern part near the Harris moraine. It is 3 miles wide at St. Francis but narrows to only a mile at the south, where it seems to have its head.

A smaller plain of sandy outwash, which seems to be connected with the Harris moraine, covers about 2 square miles along the Isanti and Chisago County line in secs. 32,33 , and 34, T. 36 N., R. 22 W., and adjacent parts of secs. 4 and 5, T. 35 N., R. 22 W. This plain lies on the northwest side of the moraine. A still smaller area of outwash lies at the apex of the 
lobe on the corners of secs. $6,7,1$, and $12, \mathrm{~T} .36 \mathrm{~N}$., Rs. 21 and $22 \mathrm{~W}$.

On the southeast side of the area covered by the Grantsburg sublobe outwash is present in several places from Hugo to Savage. For 4 miles northward from Hugo outwash occupies the place of the inner border of the moraine. It joins at Hugo to the head of another such outwash deposit, part of which displaces even the outer border of the moraine. It extends to Bald Eagle Lake in a strip a mile wide. The flat sandy outwash plain north of Hugo is about 2 miles wide. The sandy character of the outwash denotes sluggish streams from the ice sheet. The discharge led out through the present line of swamps and meadows on the outer border of the outwash to White Bear Lake. These outwash deposits and also one at White Bear Lake pertain to the Cambridge and Isanti moraines.

At the north limit of St. Paul, at Gladstone, there is a small outwash deposit of fine gravel connected with the outer or Pine City moraine, with a discharge to the south end of Phalen Lake. A small outwash plain from New Canada to Cardigan Junction appears to be its successor and to connect with the Cambridge moraine, and another near Marsden Lake seems to pertain to the Isanti moraine. Another series of outwash deposits lies between St. Paul and New Brighton. There is about 2 square miles of gray gravel outwash belonging to the Pine City moraine west of Lake Como, along the city limits, and at the border of the young gray drift. A little back from the border, near McCarron Lake, is an outwash area of about 1 square mile. Near this one another deposit less than a mile wide but 3 miles long heads at New Brighton. It pertains to the Cambridge moraine, but another immediately beyond it at New Brighton is apparently to be correlated with the Isunti moraine. This series of deposits consists of fine sandy gravel, denoting weak drainage.

At the southeast base of the Grantsburg sublobe there are extensive areas of outwash extending back into the city of Minneapolis. The earliest outwash, pertaining to the Pine City moraine, lies south of Mendota in Dakota County. It covers about a square mile in secs. 1 and 2, T. 27 N., R. $23 \mathrm{~W}$., and had southward discharge along a depression called Rich Valley to the Vermilion River. Large outwash deposits following this one were made from the Cambridge and Harris positions of the ice border, but they were drained eastward through a lower channel along the present course of the Mississippi between the mouth of the Minnesota River and St. Paul. The angle between the Minnesota and Mississippi Rivers south of Minneapolis is occupied by about 30 square miles of sandy outwash, not including about 20 square miles that was reworked by the glacial rivers that later came down the Mississippi and Minnesota Valleys. Aside from some small till tracts the outwash extends from the center of Minneapolis to Bloomington and from Minnehaha to St. Louis Park. The part of this outwash that extends eastward from Cedar, Calhoun, Harriet, Grass, and Wood Lakes pertains to the Cambridge moraine, and that which lies west of the chain of lakes, from Bloomington to St. Louis Park pertains to the Harris moraine, which also includes some small areas along Bassett Creek. About 15 square miles of fine gravel deposit north of Minneapolis, extending from Robbinsdale north and east to Shingle Creek, appears to occupy a reentrant angle in the Harris moraine.

Drainage from the Grantsburg sublobe as a whole, while the Rush Lake morainic system was being formed, caused the beginning of two new river valleys. That from the north side of the sublobe established the present course of the St. Croix by Taylors Falls. The subsequent widening of its valley by the drainage from glacial Lake Duluth cut away part of each moraine above Taylors Falls.

Drainage from the south side of the sublobe gathcred at St. Paul. That which came from the west made a new valley from Fort Snelling to St. Paul, but it occupied an old valley from St. Paul southward. The glacial river terraces are described in a separate section (pp. 87-88).

Intermorainic plains.-Dune sand covers intermorainic plains as well as moraines to a great extent, and this sand and the extensive outwash deposits already described reduce the exposed ground moraine to rather small and scattered areas. Only groundmoraine surfaces will be described under this heading.

In eastern Sherburne County, south of Zimmerman, in secs. $28,29,30,31,32$, and 33, T. 34 N., R. 26 W., is an undulating deposit of clayey till. East of Zimmerman, between the Cambridge and Harris moraines, is a sandy-till plain. It has a few feet of till intermixed with the underlying outwash of sandy gravel. It occupies part of sec. 3 and most of secs. 10, 11, 14, $23,26,35$, and 36 , T. 34 N., R. 26 W., and extends into secs. 1 and 2, T. 33 N., R. 26 W. This ground moraine castward in Anoka County is made up of heavy clayey till in secs. $4,5,6,7$, and 8 , T. 33 N., R. 25 W., and secs. $26,27,33,34$, and 35 , T. 34 N., R. 25 W. But ground moraine in secs. 17, 18, and 19, T. 33 N., R. 25 W., and secs. 13,14 , and 25 , T. 33 N., R. 26 W., is sandy till, a thin and variable sheet over gravel beds. The ground moraine between the Isanti and Harris moraines in Anoka County is also sandy or loosetextured till. The narrow ground moraine between the Pine City and Cambridge moraines in the southwest corner of Isanti County has sandy till in secs. 29 
and 31 , T. 35 N., R. 25 W., and sec. 5, T. 34 N., R. 25 $W$., and clayey till in parts of secs. $8,9,17,20$, and 21 and all of secs. 15 and 16, T. 34 N., R. 25 W.

On the east side of the Rum River, east of Isanti and Cambridge and farther north, the ground moraine is rather strongly undulating, and the till is loose textured. There is a high area of clayey till of about 5 square miles around Grandy, east of Stanchfield Lake. Another of similar area between Stanchfield and Rush Lakes is low and poorly drained.

East of Rush Lake, in Pine and Chisago Counties, between the Cambridge and Harris moraines, there is a level but well-drained till plain of about 30 square miles, part of which is heavy clay till. South of the Harris moraine around Harris is a clay-till area of about 5 square miles with little or no cover of dune sand. In Pine County, between the Pine City and Cambridge moraines, is an undulating area of clayey till. The extensive ground moraine in Chisago County is mainly clayey till.

South of Forest Lake the ground moraine is about 4 miles wide between the moraine on the east and dune sand on the west. It is 3 miles wide where it lies between Hugo and Centerville but narrows to a point at the south, between the moraine and the dune sand. Ground moraine is not sharply defined from White Bear Lake southwestward to the Minnesota Valley, where the gray-drift moraines ride upon the red-drift moraines, as indicated above.

Eskers.-There are two eskers associated with the Rush Lake morainic system. One runs from the northwestern part of sec. 16 to the southeastern part of sec. 8, T. 33 N., R. 25 W., in Anoka County. It is about 15 feet high and is very narrow. It contains gray gravel of medium coarseness. Another esker runs from sec. 17 to sec. 6, T. 36 N., R. 21 W., to the inner border of the Harris moraine. A sandy continuation of it as part of the moraine runs into sec. 36 , 'T. 37 N., R. 22 W., to an old shore of Rush Lake. This esker has points fully 30 feet above the border plain. It is composed of a rather sandy gravel.

\section{CROW RIVER MORAINTC STSTEM}

The name Crow River, taken from the Crow River drainage basin, in Hennepin and adjacent counties, is here applied to a morainic system comprising four moraines which are merged into a morainic complex at the reentrant angles between the Grantsburg sublobe and the main lobe. The moraines spread apart within the sublobe. On account of the successive adjustments of the margin of the ice to the land surface the course of each of the moraines is somewhat sinuous, so that they have together the appearance of interlacing. They also encroach slightly on the Rush Lake system. This system is merged with the Rush Lake system and to some extent overrides it on the southeast side of the Minnesota Valley in the vicinity of Jordan, where the east side of the sublobe branches off the main lobe. It is more distinct from the Rush Lake system on the opposite side of the lobe in the vicinity of Hutchinson. During the development of the Crow River morainic system the Grantsburg sublobe decreased in length and width to the point of vanishing.

There are four moraines in this system, here described as the Anoka, Loretto, Delano, and Montrose moraines, from villages situated on them. On account of the great thickness of till and heavier glaciation these moraines are not much confused by the moraines of Patrician red drift over which they lie. Also only that part of them which lies east of the Mississippi is much concealed by either outwash deposits or sand dunes.

Anoka moraine.-From a point north of Willmar, Kandiyohi County, to a point south of Litchfield, Meeker County, extends a complex morainic system of the Des Moines lobe that appears to be the correlative of the entire Crow River system of the Grantsburg sublobe. Southwest of Darwin a moraine separates from the system of the main lobe and runs thence by Darwin northeastward to the east border of Meeker County, with a width of 3 to 4 miles. It appears to be the Anoka moraine. (See pl. 2.) The rest of the complex system also turns north of Hutchinson, and the greater part of it runs northeastward between Dassel and Cokato. It divides north of Cokato into two moraines, and one of these, the Loretto moraine, again unites with the Anoka moraine. The united moraine continues northeastward in Wright County, between Hutchins and French Lakes, by Annandale to Silver Creek village, west of Monticello. The united moraine is 3 to 4 miles wide, or about the width of each of the two separate ones. At Silver Creek the moraines separate, the Anoka continuing northeast and the Loretto turning southeast.

The Anoka moraine is obliquely cut off, or displaced by outwash deposits, near Enfield, just west of the Mississippi River. East of the river it is mostly concealed by outwash and by dune sand. Its course was probably, however, nearly due east from the river past the north side of Big Lake and including morainic tracts in secs. $15,21,22$, and 24 , T. 33 N., R. $27 \mathrm{~W}$. In secs. 18,7 , and 8 and the southern part of secs. 4 and 5, T. 33 N., R. 26 W., it is covered by dunes, but farther east it is exposed. It turns south along or against the Harris moraine, and part of it is seen in secs. $9,16,21,27$, and 35, T. 33 N., R. 26 W. It is displaced by outwash from that area south for 10 miles to Anoka. The terminal position held by the ice is shown, however, by raised outwash deposits to 
have been from secs. 6 and 7 to secs. 24,25 , and 36 , T. 32 N., R. 25 W. and thence down to Anoka.

South of the glacial Mississippi Valley the moraine sets in near Champlin, across from Anoka, and runs about 3 miles wide in a southwesterly direction by Hayden Lake and across secs. 15 to 18, T. 119 N., R. $22 \mathrm{~W}$. It turns then south-southeast to the west side of Medicine Lake and then south-southwest to Lake Minnetonka, along the east side of which it extends to Excelsior. Its width east of Excelsior is about 3 miles. From that place it runs southeastward, passing east of Eden Prairie station, to the Minnesota Valley. South of the Minnesota it is massed with other moraines. It may override the entire Rush Lake morainic system and form the border of the young gray drift in the vicinity of Orchard Lake.

Loret to moraine.-The Loretto and Delano moraines together turn at a right angle at the separation of the Grantsburg sublobe from the Des Moines lobe, north of Hutchinson, McLeod County. The two moraines run side by side northeastward between Dassel and Cokato, in Wright County, with a combined width of 5 to 6 miles. They separate south of the North Fork of the Crow River, and within a short distance the Loretto moraine (pl. 2) joins the Anoka moraine, as already indicated. From Silver Creek the Loretto moraine leaves the Anoka and turns gradually southeastward to Pulaski Lake, north of Buffalo. At the lake it turns at right angles and runs again northeastward, reaching the Mississippi between Monticello and Otsego. This moraine, which is about 3 miles wide, is cut across obliquely for 5 miles near Otsego. North of the gravel plain along the Mississippi and Elk Rivers at that place the outer part of the Loretto moraine lies in the southern part of sec. $24, \mathrm{~T} .33 \mathrm{~N}$., R. 27 W., and the southern part of secs. 19 and 20 and the northern part of secs. 30,29 , and 28 , T. $33 \mathrm{~N}$., R. $26 \mathrm{~W}$. The entire width of the moraine was cut away by the glacial Mississippi at Elk River village, but the outer border appears to cross the southwest corner of sec. 35, which is covered with sandy till. Southeastward from that place the position of the moraine is occupied by thick outwash deposits, but the ice edge appears to have pushed out 3 miles east into Anoka County. Its apex was probably on the present Mississippi 4 miles below the mouth of the Crow River, at the farthest, and 2 miles above the Crow at the completion of the terminal moraine.

From its apex the outer border of the Loretto moraine runs 3 miles south of Dayton to the Crow Valley and thence southwestward along the valley. The inner border runs by St. Michael to Rockford, the width of the moraine being 3 to 4 miles. The moraine then enters a depression along the preglacial valley of the Mississippi, by an eastward deflection into it. The outer border of the moraine runs southeastward from a point 4 miles east of Rockford, by Loretto to Wayzata, southwest to Minnetonka Beach, and across Lake Minnetonka southward to Excelsior. The inner border from Rockford continues south to the Great Northern Railway 2 miles east of Delano and along the railway past Maple Plain, then in an irregular course past the east side of Whale Tail Lake to Zumbra Heights. That part of the moraine is 4 to 7 miles wide, including the lake basins and swamps, which are relatively large. The Loretto moraine reaches the Minnesota Valley between Terrell and Hazeltine Creeks, opposite Shakopee. Its continuation south of the valley is in a southeasterly direction from Shakopee, but its borders are merged with those of the preceding and following terminal moraines.

Delano moraine.-Where the Delano moraine (pl. 2) separates from the Loretto moraine, north of Cokato, as already described, it is about 2 miles wide. Its course is northeasterly to Rock and Ramsay Lakes, south of the village of Maple Lake. The moraine then has a general southeasterly course but makes several meanders. It first runs directly to Buffalo Lake at Buffalo. Part of it turns south on the west side of the lake to the North Fork of the Crow River, and part of it goes around the lake and then south to the North Fork. The width here is about 4 miles. It runs obliquely across the North Fork and also the South Fork, so that the confluence of the streams is near the outer border of the moraine. It is nearly 3 miles wide at and south of Delano. From Delano it runs obliquely across the county boundary into Hennepin County, covering also about a square mile of the corner of Carver County. In Hennepin County it runs alongside the Loretto moraine. The outer border runs by Victoria and Chaska; the inner border runs by St. Bonifacius, east of Waconia, and by Augusta to a point a mile west of Carver.

Montrose moraine.-The last terminal moraine of the Grantsburg sublobe, the Montrose moraine (pl. 2), is, of course, the shortest and it is a little weaker than the three preceding. At the place of separation from the main lobe, in McLeod County, the moraine runs from Hutchinson, 8 miles east, to secs. 5 and 8, T. 116 N., R. 28 W., and then northeast to the county boundary in secs. 3 to 5, T. 117 N., R. 27 W. It is 2 to 3 miles wide there. In Wright County its course is first nearly north to Howard Lake. It is spread out somewhat irregularly south and west of that village but is exceptionally narrow toward Waverly. The moraine runs north of Waverly to Montrose and southward to Watertown. From Watertown to the Minnesota Valley it is from 3 to 5 miles wide and sinuous in course. It makes a reentrant southwest from Watertown and another stronger one southwest from 
Waconia. A third reentrant which has been nearly all cut away by the glacial Minnesota River was at St. Lawrence and marked the separation of the sublobe from the main lobe.

Topography.-Of the four members of the Crow River morainic system the two outer ones are the strongest. All are distinet terminal moraines. Wherever one of them crosses a depressed area or old valley it is rougher or more irregular than elsewhere. All the moraines are exceptionally prominent, and some linolls form eminences.

Composition.-The moraines of the Crow River system are made up prevailingly of clayey till. As is usual in terminal moraines, some knolls include gravelly beds or pockets. Gravelly loose-textured till prevails in the part of the Anoka moraine and Loretto moraine north of the Mississippi River. The part of the Loretto moraine on the east side of the Crow River from Hassan to Hanover consists of loose-textured till. A belt of red outwash gravel covered by gravelly gray till a mile or less wide lies across the Anoka moraine from Hopkins past the north side of Shady Oak Lake and both sides of Glen and Island Lakes to Duck Lake, west of Purgatory Creek. A small area of such drift borders Prior Lake, in Scott County.

Associated outwash and glacial drainage.-At Annandale there is an outwash plain which covers about $\tau$ square miles, lying south of John, Pleasant, and Clearwater Lakes. Its position is in the line of the Anoka and Loretto moraines. Drainage from this plain went northward by way of the Clearwater Valley. Another outwash deposit from these moraines, a mile wide, extends in the Silver Creek Valley from a point near Silver Creek village northward for 3 miles and west of Enfield along the Mississippi to Fish Lake. The altitude of this outwash is about 1,000 feet. Its deposition was contemporary with or slightly preceded the opening of the section of the Mississippi which it touches. This deposit includes outwash deposits at Becker, Sherburne County, which extend 4 miles west of this village, northeastward to the Elk River, and thence to Big Lake. Drainage from the Clearwater Valley, the Silver Creek Valley, and the area around Becker all went north through Elk Lake to the St. Francis River and probably down the Rum River Valley.

The outwash deposit north of Becker lies in front of the Anoka morainic position, but it is continuous with gravel deposits south of that place which were formed upon the recession of the ice border as far south and east as the confluence of the Elk and St. Francis Rivers. South of that point are outwash. gravel deposits pertaining to the Loretto moraine, on both sides of the Mississippi. This outwash appears to have been laid down at the front of the Loretto moraine west of Monticello and within the moraine sciuthward to Pulaski Lake, which lies in a reentrant of the moraine. It was spread northeastward to Big l $\lrcorner$ ake and the Elk River. Drainage from all the outwash plains south and east of Big Lake escaped either under the front of the ice or along it by the present town of Elk River.

At Osseo gravel outwash spread from the front of the Anoka moraine southeastward on the north side of Shingle Creek. At the same time an outwash deposit at Anoka was spread eastward to Coon Creek, from the present line of the Rum River. West of the Rum River at Anoka and north to Trott Brook there is a pitted outwash plain formed in place of the moraine. It extends westward to the place where outwash gravel lies in the position of the Loretto moraine, and that extends back to the Mississippi nearly as far up as Elk River.

The next outwash deposit in the succession is one on the Crow River. It is about 10 miles long and 1 mile wide and extends from Dayton to Hanover. It lies in the Loretto moraine and is about 880 feet above sea level. Farther up the Crow River, near Montrose, about 10 square miles of sandy outwash lies along the valley of the North Fork for 8 miles and is all within the Delano moraine. A small tract of about 2 square miles is found north of Cokato Lake.

Drainage from the Anoka and Osseo outwash plains was carried through a succession of ponds along the line of Coon Creek and the Mississippi River. But by the time the ice began to shrink back, drainage came along the fosse to Anoka and then out across the gravel plain. The course of the Rum River was probably opened at that time by drainage from the outwash at Becker and points farther northwest. While outwash gravel was being deposited north of Dayton, from the position of the Loretto moraine, drainage from it appears to have been sluggish along and north of Trott Brook to the Rum River. Whatever streams from the Elk River found their way around and under the end of the ice, the first permanent channel was late in forming. The present course of the Mississippi is through rather than around the outwash from the Loretto moraine. The highest terrace in the valley below Dayton, at 880 feet above sea level, is in harmony with the outwash plain on the Crow River above Dayton, which was completed near the inner border of the moraine. This shows that a river flowed by Dayton at that time. Later drainage from the outwash plain on the North Fork obviously went down the Crow Valley to the Mississippi.

Outwash deposits along the Minnesota Valley were strongly developed in association with the Crow River morainic system. The outwash includes the gray 
gravel over the red gravel of Eden Prairie, derived from the Anoka moraine. This outwash deposit covers about 7 square miles, extending from Bloomington Ferry to Eden Prairie station and northward to Duck Lake. An outwash plain that belongs with the Loretto moraine extended from a point 2 miles west of Shakopee eastward, but nearly all of it was soon afterward overswept by the glacial Minnesota River. This plain is known as Shakopee Prairie. It extends along the south side of the valley for 8 miles and has a width of about a mile. Part of the head of the outwash was not overswept and is preserved on the line of secs. 13 and 14, T. 115 N., R. $23 \mathrm{~W}$. About 5 square miles of gravel southwest of Carver belongs with the Montrose moraine. Drainage from the outwash of Eden, Shakopee, and Carver Prairies took an eastward course. The drainage channels and largely the plains also were later swept out by the glacial Minnesota River.

Associated ground moraine.-The ground moraine within the Crow River morainic system is prevailingly clayey till in a rather uniformly thick deposit. It is tigh and comparatively well drained for the greater part. Between the Anoka and Loretto moraines there is an area of several square miles near Dassel, and a larger one of about 90 square miles near Hamel and Hassan, including Corcoran Township, in Hennepin County. This larger area has an undulating surface and is evidently superposed on a moraine of red drift.

The ground-moraine area between the Loretto and Delano moraines is nearly divided into three parts. The central part, of about 80 square miles, lies between Buffalo, Rockford, and Otsego. A western part of about 60 square miles lies beyond Buffalo, around Maple Lake village, and extends southwestward across the Crow River. A third part of about 20 square miles lies beyond Rockford, between Delano and Maple Plain. It is all more or less undulating clayey till. An isolated tract of about 5 square miles lies between the two moraines between Victoria and Zumbra Heights. This tract is about half swamp.

The ground moraine between the Delano and Montrose moraines is the widest near Hutchinson. A strip 4. to 6 miles wide and 25 miles long extends from Hutchinson toward Buffalo Lake, passing between Cokato and Howard Lake village. A narrower strip extends from a point north of Waverly and Montrose southeastward to Watertown. The lake at Waconia lies chiefly in a small area of ground moraine between the Delano and Montrose moraines. North of the lake, near St. Bonifacius, a high table-land of about 10 square miles belongs in the same intermorainic plain. Between Augusta and Carver there is several square miles of ground moraine. This tract is cut across by the Minnesota Valley, and its continuation south of the valley is a triangular area 2 miles wide and 8 miles long running southeastward from Merriam.

\section{GLACIAL RIVER TERRACES}

The valleys of the St. Croix, Mississippi, and Minnesota Rivers were largely made by glacial rivers that swept through them across the area of the Grantsburg sublobe, from sources outside of this area. Each was a new valley, made as the result of the drainage being turned by the discharge from the ice sheet. The glacial St. Croix River, which might otherwise have fiowed by North Branch and Dayton, was turned in front of the Grantsburg sublobe to the course of the present river between the diabase ridges at Taylors Falls. It carried at first drainage from the north side of the sublobe and from Kettle River. With greatly increased volume from Lake Duluth the glacial river cut a deep and wide valley. This cut into the first three moraines of the Rush Lake system, as already described. The glacial Mississippi broke across this area a little later than the St. Croix and was also of shorter duration as a glacial ștream. The glacial Minnesota started when the front of the Keewatin ice sheet began its retreat. The river increased in volume as well as length with the recession of the ice and the development of the glacial Lake Agassiz, and it remained large to the end of the Wisconsin stage of glaciation and the eastward diversion of the waters of Lake Agassiz. The river as it flowed from the ice sheet is called the glacial Minnesota, but as the outlet of Lake Agassiz it is known as the River Warren. ${ }^{2}$ The Rum and the Elk are related to the outwash plains, as already described in that connection.

Terraces of St. Croix Valley.-At the north end of the area covered by the Grantsburg sublobe, opposite the mouth of the Snake River, the erosion valley of the glacial St. Croix is limited by a prominent bluff 3 miles west of the present stream. This bluff continues prominent to the south and is 2 miles from the river opposite Rush City and 3 miles from it opposite Harris. The bluff describes a large curve between North Branch and Sunrise around an area of bottom land 6 miles wide. The terrace or flat between the bluff and the river channel near the mouth of the Snake River is thickly strewn with boulders, but farther south the stony spots are scattered or are covered with sand and fine gravel. Most of this flat is wet meadow.

Below Sunrise the valley is narrower, though there is a gravelly terrace more than a mile wide at Amador. From Amador to Taylors Falls there are terraces extending about half a mile back from the river. They are more or less covered by river sand. Below Taylors Falls the valley was cut to a very low gradient by the outflow from Lake Duluth, and its bluffs are over 200 feet in height. The width of this part of the valley is a mile or more. The river spreads over

\footnotetext{
${ }^{2}$ Upham, Warren, Am. Assoc. Adv. Sci. Proc., vol. 32, p. 231, 1884
} 
much of the bottom and is known as Lake St. Croix. It has been ponded at its lower end to a depth of about 40 feet by the aggradation of the Mississippi Valley opposite its mouth since the Lake Duluth waters ceased flowing through it.

Terraces of Mississippi Valley.-At the west base of the Grantsburg sublobe the town of Clearwater stands on a narrow terrace more than a mile long and 960 feet above sea level between a 40 -foot bluff back of it and the recent valley bottom below. This terrace is really the continuation of an abandoned channel of the glacial river that leads from the main valley at St. Augusta up Thompsons Creek to sec. 24, T. 123 N., R. 28 W., and thence southeast to the mouth of the Clearwater River. Both the channel and the terrace have a sandy or gravelly surface. Monticello likewise stands on a sandy terrace about 930 feet above sea level. It is about half a mile wide, and an arm of the glacial river of this width and 4 miles long leads to it from the upstream direction. The terrace is cut off by the deeper valley below the town, but a mile down another remnant of it is preserved. It is half a mile long and about the same width. At Otsego a wide terrace of the same kind covers about 7 square miles in Wright County, where the glacial river cut away the Loretto moraine. Across the river from Otsego there is a terrace half a mile wide and 4 miles long which ends at the Elk River. A narrow terrace extends from a point opposite Dayton to Anoka, but on the right side of the river, from a point 3 miles above Anoka to Fort Snelling, the terrace or glacial river bed is about a mile in width. East Minneapolis occupies the same bed on the east side of the river. These terraces are all more sandy than the outwash plains, but in a few places where boulders appear the sandy gravel is thin.

Terraces of Minnesota $\nabla$ alley.-The valley of the Minnesota River has terraces representing two stages of the river besides the present flood plain, which is the partly filled channel of the River Warren. The higher terraces include Belle Plaine Prairie, at 850 feet above sea level, or more than 100 feet above the river. It extends with slight interruption from Blakely to Jordan, a distance of about 12 miles, and is 1 to 2 miles wide. A corresponding plain half a mile to 2 miles wide begins across the valley from Belle Plaine and extends for 10 miles to Carver. The next one downstream, known as Shakopee Prairie, is about 10 miles long and nearly 2 miles wide in its widest place. On the opposite (north) side of the valley is Bloomington Prairie, at 820 to 840 feet above sea level, which extends for 10 miles from Bloomington Ferry to Fort Snelling and has a width of 1 to 2 miles. These high terraces are gravel plains with loamy surface for the greater part.
The lower terraces have an irregular and partly. rock-floored surface. The part at St. Lawrence is protected by a limestone ledge at its west end with a hill of boulders over till rising above it. At Jordan and northward to Merriam it is partly covered by dune sand and by the alluvium of Sand Creek. At Merriam it is rock floored. Beyond Merriam it is narrow to Shakopee, but at this place it begins to spread again and has a bare rock surface. The rock formation dips to the east, however, and is soon covered by a gravel bank or by dune sand. At Savage there is a bare rock terrace $11 / 2$ miles in greatest width.

Other river terraces.-The Crow Valley has a terrace at Greenwood and Rockford which relates to the glacial Crow River. It is small compared to those of the larger rivers. Somewhat larger local flats on the Crow, the Elk, and the Rum are the beds of lakes which the streams have traversed and completely drained by cutting away their rims. These flats have the irregular borders of the old lake shore.

\section{DUNE SAND}

General character. $\rightarrow$ Dune sand in this region is distinguished from other sandy deposits, glacial outwash, and glacial river terraces in several ways. The surface of dune-sand areas has a tendency to be rolling; the surface of the outwash is generally flat. The dune sand lacks the bedding characteristic of water-laid deposits and generally contains no pebbles. The outwash and terrace deposits, on the other hand, have generally assorted or laminated structure and are generally pebbly. Another distinguishing feature is that the dune sand gives a carpetlike softness to the soil or the road bed, whereas the glacial outwash has rather sharp sand that gives a more gritty sound under the wheels. The areas of dune sand lie adjacent to outwash plains or river flats as a rule, and the dunes seem to have derived their material from sandy parts of the outwash and river terraces. Few of them, however, rest on such deposits, but, on the contrary, they are underlain by clay or till, which may be either terminal moraine or ground moraine. Dune-sand deposits are of wide extent east of the Mississippi, in Sherburne, Isanti, Chisago, and Anoka Counties and parts of Mille Lacs, Ramsey, and Hennepin Counties. Only a few small tracts of dune sand are found west of the Mississippi.

Mode of deposition.-The dune sand was gathered by the wind from the glacial outwash deposits and river terraces and to some extent from surfaces of sandy till and from lake shores. The depth and extent of each deposit are proportional to the magnitude of the main source. The sand was heaped into ridges or dunes, which then traveled with the wind from the place of origin until caught and held by wet ground 
or by vegetation, which was as a rule over a surface of clay till. Associated or interbedded with the sand are thin layers of dust, which, brought in by the wind, had settled in patches in the lee of the dune ridges, where vegetation was heaviest. The moving dune sand often covered the dust deposits, which are therefore deeply buried under the coárser material.

The prevailing wind that whipped up the sand into dunes was from the southwest, as is shown by the shape and position of the dunes and their relation to the outwash plains and river terraces. The dune sands are obviously northeast of their source. In places materials of the outwash are found to grade northeastward into the dune sand. Here and there coarse sand and even fine pebbles extend for a mile or more from the gravelly tracts into the dune-sand areas. A few dunes remain in isolated positions upon the gravelly areas where they originated. They appear to have been caught and held by vegetation before they had traveled far. The dune sand seems to have been washed out and deposited in the area of the Grantsburg sublobe while the ice front was retreating. It was then acted upon by wind until the land surface was completely covered and protected by vegetation. Inasmuch as the Mississippi Valley was occupied by a larger stream than the present river for a considerable time after the Grantsburg sublobe had uncovered it, the sandy strip along it may have been flooded and not exposed to wind action until the stream had been reduced to its present size and confined to its present narrow channel. In that case dunes along its east border may have received accessions at this later time.

Extent and depth.-It should be borne in mind that this region is still thinly settled and to a large extent covered with brush. On this account exposures are scarce and so shallow as to throw little light on the thickness of the sand. It is very probable that a considerable part of the area represented on the map as covered with dune sand carries very little wind-deposited material.

The main area of dune sand east of the Mississippi is estimated to cover 840 square miles, with the included swamps and lake basins. It is distributed in several counties-Sherburne 160 square miles, Mille Lacs, 20, Isanti 250, Chisago 100, Anoka 300, and Ramsey about 15 . The area is continuous but comprises three main districts with respect to origin and distribution. One has its base on the Elk River, in Sherburne County; a second has its base on the Mississippi, in Anoka County; and a third lies between the other two, in Isanti County. About 15 square miles in the northwest corner of Sherburne County is a distinct area. It is narrowly joined to the main area on the east and lies outside the gray-drift border upon red till.
The Sherburne County area extends from the vicinity of the Elk River across the St. Francis and Rum kivers to Stanchfield Creek, covering also parts of Mille Lacs and Isanti Counties. The western part of the area, which lies north of Becker, from the Elk to the St. Francis, is a network of low sand ridges with meadows and swamps, known as the Thousand Islands. South of Zimmerman swamps and some till interrupt the dune sand. The main part of the area, however, is a high, gently undulating sandy plain. In central Sherburne County the sand is relatively coarse and the deposit is thick, but as it passes northeastward into Isanti County it becomes more dusty, with interbedded dust layers. The main source of the dune sand for this area was the outwash plain and river terraces along the Elk and the Mississippi. At Becker, where the outwash plain becomes narrow, a considerable till tract is not covered with sand, but opposite the wide gravel plains near Monticello and Big Lake the sand deposit is deep. Considerable addition was made, no doubt, from the deposits on the St. Francis River, Battle Brook, and the Rum River.

The streams not only brought in some material from the north, but their direction of flow is such that sand blown into their valleys would be carried eastward before being. again caught by the wind from their farther shores. The trend of the whole area is therefore more eastward than it otherwise might have been. In a few places the sand is now being shifted by the wind-for example, in sec. 27, T. 34 N., R. 27 W., and in secs. 3,17 , and 20, T. 33 N., R. 27 W.

The Anoka area extends from the vicinity of the Rum and the Mississippi, between St. Francis and Minneapolis, northeastward to the St. Croix Valley between Harris and Sunrise. A wide tract known as the Wiregrass Marsh, between the mouth of Coon Creek and the head of the Sunrise River, near Wyoming, is mostly overgrown with peat. But the main part of the area is a dry, gently undulating plain. The sand is coarser and deeper through the middle of the area than near the borders. The main source of sand for this area was the bed and borders of the glacial Mississippi and of the Rum River. Outwash plains contributed also. Shifting sand with blowouts was noted in secs. 34,35 , and 36 , T. 32 N., R. 24 W., and on the east side of secs. 14 and 23, T. 30 N., R. $24 \mathrm{~W}$.

The Isanti area is between the two just described and is all in Isanti County. It lies in the angle made by the Rum River from Spencer Brook to St. Francis and extends northeastward across the river at Cambridge. The dune sand perceptibly grades from coarser to finer in passing northeastward from the outwash and sandy till on its southwest border. It is notably thicker and coarser than that of the area 
north of the Rum River. It becomes more filled with dust toward the northeast. An evident source of this sandy deposit was the outwash plains and sandy till tracts south of it.

Isolated dunes and small tracts of dune sand are found in several places west of the Mississippi River. In Wright County a narrow strip lies on the left side of the Crow River, from sec. 7 to sec. 17, T. 119 N., R. $26 \mathrm{~W}$. Another on both sides of the stream is mostly in secs. 23 and 25, T. 119 N., R. 25 W. The sand in both these strips was derived from the exposed bars and shores of the river. The sand on somewhat larger tracts was gathered from the terraces of the Minnesota Valley. One of these tracts, 3 miles long, extends from Minnehaha Falls southward to the Minnesota Valley. Two other tracts, one near Shakopee and one near Jordan, are upon the lower terrace of the Minnesota.

The dune sand is yellowish and dusty when dry. The cleaner sand has the lighter color. The amount of dust or fine material varies and so does the coarseness of the sand grains. The coarser, cleaner sand is abundant near the sources of supply; finer, dustier sand prevails to the leeward-that is, toward the rortheast. Where coarse and fine grained bands alternate, the fine bands are thin and irregular.

If denuded of vegetation the sand is liable to be shifted by the wind. Some fields that have been plowed and left exposed too long without vegetation have their soil blown into drifts. In this way the fine or dusty part is lost and the coarser part of the sand remains to an injurious depth on the land.

\section{MINOR MORAINES OF WISCONSIN GRAY DRIFT IN MINNESOTA RIVER BASIN}

The strong Altamont and Gary morainic systems described above (pp. 67-77) lie near the border of the drainage basin of the Minnesota River and extend a loop into the Des Moines drainage basin to the south. (See pl. 3.) On the northeast they form the border between the Red River and Minnesota River drainage systems and that of the Mississippi River. After it formed these strong morainic systems the front of the ice lobe seems to have made only a few brief halts in the course of its recession from the Minnesota drainage basin. These halts are indicated by relatively weak moraines, with wide till plains separating them. These moraines are more nearly continuous and better defined on the west and south borders of the ice lobe than on the northeast border. The ice front seems also to have held its position along the edge of the Gary morainic system on the northeast border while making a considerable retreat on the south and west borders, for the shady side held its position longer than the sides more directly exposed to the sun. A slight pro- trusion on the northeast border opposite the Grantsburg sublobe seems also to have melted away while the ice border was still holding its position at the inner edge of the Gary morainic system. This protrusion was in the Crow River drainage basin, which is outside that of the Minnesota River and directly tributary to the Mississippi River. In this connection it should be noted that a small part of the East Des Moines drainage basin falls within the district traversed by one of the weak moraines under discussion in southern Minnesota and northern Iowa.

Names have been applied only to the best defined of these moraines, or those which maintain a distinct course for a considerable distance. One of these was named by Chamberlin ${ }^{3}$ the "Antelope Hills or Third Moraine," on the supposition that it came next in succession after the Gary moraine, which he considered the second moraine, while the Altamont was thought to be the first moraine. It has already been shown that the Altamont was not the first moraine of Wisconsin drift in the Des Moines lobe but was preceded by the Bemis moraine. These ordinal names should therefore be dropped, as they are all inapplicable. It is also shown in the discussion below that the Antelope moraine was not the first one formed aftei the Gary, but that two or more moraines, similar in strength to the Antelope, lie between it and the Gary morainic system. Others in southern Minnesota, only partly mapped by Upham, lie between the Antelope moraine and the Minnesota River and show clearly the shape of the lobe, step by step, in its recession from the Minnesota drainage basin. These minor moraines were mapped in part by Sardeson but mainly by Leverett in the field seasons of 1912 and 1915.

The great loops made by the Bemis, Altamont, and Gary morainic systems in the Des Moines drainage basin justify the use of the name Des Moines lobe for the part of the ice sheet that extended from Minnesota southward into central Iowa. But when the ice had shrunk to the limits marked by the later moraines under discussion its lobation was mainly in the Minnesota drainage basin, with scarcely any extension into the Des Moines Basin. These moraines may therefore be more appropriately termed the moraines of the Minnesota Valley lobe. Still later the ice lobe was mainly in the Red River drainage basin, with scarcely any extension into the Minnesota Basin, and for that phase the name Red River lobe seems to be appropriate and significant.

\section{FAIRMONT MORAINIC SYSTEM}

Extent.-The Fairmont morainic system (pls. 2 and 3) takes its name from the county seat of Martin

${ }^{3}$ Chamberlin, T. C. Terminal moraine of the second glaclal epoch : U. S. Geol. Survey Third Ann. Rept., pp. 388, 393, 1883. 
County, Minn., which stands on a part that is exceptionally prominent. It is a well-defined morainic belt no farther north on the west side of the lobe than the ridge of quartzite in northeastern Cottonwood County. From the east end of this ridge it takes a course slightly east of south across western Watonwan Couniy to Fox Lake, in Martin County, the villages of Darfur, Butterfield, Odin, Monterey, and Triumph being on or near it. Its width ranges from about 1 mile to nearly 3 miles. Where widest, from Monterey to Fox Lake, it is separable into two or three distinct ridges, separated by narrow strips of ground moraine. But north of Monterey it is a single moraine, somewhat less than 2 miles in average width. The moraine makes an abrupt eastward turn at Fox Lake and is represented by three or four rather ill-defined morainic ridges between this lake and the Middle Chain of Lakes, near Fairmont. The outer one lies south of the Chicago, Milwaukee, St. Paul \& Pacific Railway much of the way from Welcome to Fairmont. Two others lie northeast of Eagle Lake, in T. 103 N., R. 31 W., and one lies north of Elm Creek, in the southern part of T. 104 N., R. 31 W. Fairmont stands near the inner border of the morainic system. The Middle Chain of Lakes in T. 102 N., R. 30 W., lie in it, but those in T. 101 N., R. 30 W., lie outside or west of the morainic system. The lakes of the East Chain lie in it in both of these townships. Two members of the morainic system lie between the two chains of lakes, and one lies east of the East Chain.

As indicated on maps by MacBride in the reports of the Iowa Geological Survey, the outer border of this morainic system takes a southeastward course along or near the East Des Moines River across northeastern Emmet County to central Kossuth County, Iowa, at the junction of the East Des Moines with Buffalo Creek. It then follows the north side of Buffalo Creek northeastward about to the line of Winnebago County and continues northeastward past Buffalo Center, about to the Minnesota line, where it becomes merged with the Gary morainic system. The part in Iowa is represented by MacBride to have ridged strips separated by smooth to gently undulating ones, and these ridges are probably to be correlated with similar ones in southeastern Martin County, Minn. The present writer has examined only a part of the Iowa portion of the morainic system, that lying along and east of Union Slough, in Kossuth County, and this was found to have a complexity similar to that in Martin County.

Although the outer border appears to be blended with the Gary morainic system in the vicinity of the State line, there is a distinct but rather weak member which is traceable from the vicinity of Rake, Iowa, northeastward to Bricelyn, Minn., and which becomes merged with the Gary morainic system east of Brice$67665-32-7$ lyn. Near Walters, Minn., a moraine which may be the full equivalent of the Fairmont separates from the combined Altamont and Gary morainic systems and bears northeastward across the northwestern part of Freeborn County, passing just east of Alden and Hartland and uniting with the great morainic system in southeastern Waseca County. Farther north the Fairmont morainic belt does not seem to be distinct from the great system outside. Possibly a weak moraine in riortheastern McLeod County, running southwestward from Winsted to Silver Lake, belongs in the Fairmont system, but it seems quite as likely to be in the next later one, the St. James. This moraine is opposite the base of the Grantsburg sublobe and was developed in the course of the final absorption of this protruding part of the lobe, noted above. Farther northwest, on the part of the lobe facing the northeast, the ice border seems not to have shrunk away from the great morainic system until after the Fairmont morainic system was formed.

The Canby moraine, discussed below, may prove to be the equivalent of the Fairmont morainic system. If not, the Fairmont probably blends with the Gary system in southwestern Minnesota.

Topographic features.-From the end of the quartzite ridge in northeastern Cottonwood County southward to Fox Lake the Fairmont morainic belt presents a wavy or gently undulating surface with swells 10 to 20 feet above the depressions and with gentle slopes. The flat areas among the swells are of small extent and form but a minor part of the strip above outlined as morainic. But in the part running eastward from Fox Lake to Fairmont the flat areas occupy the greater part of the surface, less than one-fourth of it being undulatory. The outer part along and south of the Chicago, Milwaukee, St. Paul \& Pacific Railway embraces only scattered knolls, 10 to 20 feet high, occupying less than 10 per cent of the surface. But east of Eagle Lake knolls 20 to 30 feet high occupy about half the surface for 2 or 3 miles along each side of its outlet, and smaller ones are numerous along the north side of the outlet to Chain Creek at Fairmont. North of this knolly strip there is undulating land over much of the north half of T. 102 N., R. 31 W., with swells 10 to 20 feet above the depressions. In secs. 33, 34, 35, and 36, T. 103 N., R. 31 W., a strip of knolly land nearly a mile wide and 4 miles long stands about 20 feet above a plain on the north. From the east end of this strip southeastward to Northrop and thence southward into Fairmont there are small scattered knolls occupying less than one-fourth of the surface.

South from Fairmont around the lakes that have northward drainage to Chain Creek nearly all the surface is knolly, the main exception being a small gravel plain covering less than half a square mile that 
extends southeastward from Hall Lake into sec. 29, T. $102 \mathrm{~N}$., R. $30 \mathrm{~W}$. The knolls are generally 10 to 15 feet high, but a few are 20 feet or more. This strip of knolls is continued southward through the central part of T. 101 N., R. 30 W., into Iowa. Between it and the chain of lakes draining southward in the west range of sections in this township there are only scattered knolls with nearly level surface among them. There is a knolly strip west of the East Chain of Lakes in secs. 13, 14, 23, and 24, but otherwise the eastern part of the township is mainly a plain with gently undulating surface. East of the East Chain of Lakes, from sec. 24, T. 102 N., R. 30 W., southward 9 miles to the Iowa line, is a strip of sharply undulating to knolly liand with an average width of fully a mile that is here the main member of the system, many of the knolls being 20 feet or more high and closely aggregated. This strip has an indefinite connection with the Fairmont system toward the northwest, between Ross Lake, in sec. 24, and the village of Fairmont. Last from this definite moraine as far as Elmore, Minn., on the north side of the State line, and still farther east on the Iowa side of the line, there are scattered knolls, some of them of gravelly constitution, which rise abruptly 20 to 30 feet or even higher above the level tracts among them. These knolls occupy scarcely 10 per cent of the surface and should perhaps be considered features of the ground moraine rather than a part of this morainic belt.

The Iowa portion of the Fairmont morainic belt consists of narrow ridges and strings of knolls rising 15 to 30 feet or more above intervening, more gently undulating tracts in which only a few sharp knolls are found. The whole area in Kossuth County from the junction of Buffalo Creek with the East Des Moines River northward to the State line is mapped by MacBride as morainic, and so is the portion north of the Blue Earth River in Winnebago County. In Emmet County only the knolly strips are marked as morainic.

There are scattered knolls from the State line northward to the East Fork of the Blue Earth River in 'T. 101 N., R. 25 W., rising 10 to 20 feet above level tracts among them. Along the southeast side of the Chicago, Rock Island \& Pacific Railroad from Rake, Iowa, to Bricelyn, Minn., and eastward from Bricelyn to the great moraine along the south side of the Chicago \& Northwestern Railway the knolls are more closely aggregated and form a more definite moraine than in the remainder of the township. There is a nearly featureless ground moraine in the southeastern part of the township which extends a mile or so into Iowa, to the border of the combined Altamont and Gary morainic systems.

The moraine that parts from the great morainic system near Walters and, after crossing western Free- born County, reunites with it in southeastern Waseca County has a strong expression along its entire course. Knolls 10 to 30 feet high occupy most of the morainic strip for a width of 1 to 2 miles. In places basins containing marshes or ponds are inclosed among the knolls. The moraine is definitely in contrast with a strip of ground moraine 1 to 3 miles wide lying between it and the border of the great morainic system to the east.

Character of the drift.-Along much of its course this morainic belt is composed of clayey till. The till is generally oxidized to a yellowish-brown color to a depth of about 20 feet. In fact, very little blue or unoxidized till is found in this later drift along the entire course of the morainic belt. The blue or black till pertains mainly to older drifts, for they form the main body of the drift of the Minnesota River drainage basin. The Wisconsin drift in the morainic belt is only about 20 feet in average thickness, and on the bordering ground-moraine areas it is even less. As a consequence exposures of pre-Wisconsin drift are numerous in the rims of lake basins and on valley slopes. The Wisconsin drift is easily distinguished from the underlying older deposits by a general fresher appearance. The oxidized till is not of so deep a brown color, and it lacks weathered joints and seams such as abound in the older drifts. It is also much less indurated and can be easily spaded, whereas the older drift is generally so solid it has to be removed with a pick. In several places in river bluffs a dark humus-stained soil was found at the top of the older drift, to supplement the other more general distinguishing characters. The older till was noted along or near the line of this morainic belt on the borders of several lake basins in the vicinity of Fox Lake and Sherburn to a height of 10 to 20 feet above the lakes. It is also exposed on Budd Lake, near Fairmont. There is only about 10 feet of the Wisconsin drift. above the old drift in a road cut on the border of Budd Lake in sec. 18, Fairmont Township. Some laminated clay is here involved with the Wisconsin drift. On the east side of Budd Lake there is sand between the drifts. The top of the old drift is about 20 feet above Budd Lake. This chain of lakes and others in Martin County, as long since interpreted by Upham, ${ }^{4}$ seem to lie along the line of interglacial valleys which were only partly filled by the Wisconsin drift.

Gravel pits have been opened in many of the knolls along the moraine in Martin and Faribault Counties and also in knolls scattered over the plain inside (north of) the moraine. These pits usually show till intermingled with the gravel, and the beds are in many places crumpled and dislocated, probably as

- Upham, Warren, Geology of Minnesota, vol. 1, pp. 479-485, 1884. 
a result of the movement of the ice sheet against them. Gravel is found in a few places in flat areas within the moraine and on its border. An example of the border deposits is found on the line between sec. 19, T. 102 N., R. 30 W., and sec. 24, T. 102 N., R. 31 W., about 2 miles southwest of Fairmont, where perhaps 80 acres is underlain by gravel. There is a narrow strip of gravelly land along Elm Creek in its course across T. $103 \mathrm{~N}$, R. $31 \mathrm{~W}$, , which is between two members of this morainic system. At the north end of Union Slough, a short distance south of the State line, near the corner of secs. $9,10,15$, and $16, T .100, N$., R. $28, W$., is a sandy plain 8 to 10 feet above the level of the slough that seems likely to have been built up as an outwash from the ice edge when it had receded to the head or north end of the slough. The slough is a channel a quarter to half a mile wide that seems to have been cut by the water discharged from the end of the receding ice lobe. It originally drained southward into the East Des Moines River, but now, owing to peaty growths near its south end, it has been ditched northward to the Blue Earth River. On the whole remarkably little sandy and gravelly outwash is associated with this morainic belt along its entire course.

Boulders are conspicuous in but few places along the entire length of this morainic belt, yet some are to be seen on nearly every 40-acre lot. As there is very little silt or sand over the till, such boulders as are present are in plain view. On the plain inside (north of) the morainic belt there are wide areas where there is enough silt over the till to cover the boulders. One very bouldery strip was crossed by the writer about 5 miles south of Elmore, Minn., in northern Kossuth County, Iowa, which is there associated with a chain of drift knolls, but its course and extent were not determined.

\section{CANBY MORATNE}

To a weak and rather ill-defined moraine in southwestern Minnesota the writer has given the name Canby, from a village that stands on its inner border. (See pls. 2 and 3.) The Canby moraine crosses the southwest township of Lac qui Parle County in a southeasterly course and continues in this direction across the western part of Yellow Medicine County and the northeast corner of Lincoln County about to the Redwood River near Lynd, in Lyon County, beyond which it has not been identified. In part of this extent it has the position of a "riser" on a step on the slope of the Coteau des Prairies, there being a steep ascent of 75 to 100 feet in about a mile through it, while just outside, to the south, is a gentler slope for a mile or more corresponding to the "tread" of the step. Knolls are more conspicuous on this steep slope than on the gentler sloping plain outside. It seems probable that the ice border halied for a brief time at this line and produced the features just noted, but it does not seem probable that this weak moraine is the full equivalent either of the Fairmont or of the St. James morainic belt, described below. The continuation of the ice border to the southeast from Lynd may have lain along the inner border of the Gary morainic system, and this moraine may find its correlative in the weak moraine in southeastern Cottonwood, northeastern Jackson, and southwestern Martin Counties, already described as the inner Gary moraine (p. 76).

The drift of the Canby moraine and also of the plain between it and the Gary morainic system is a clayey till with few exposures of gravelly material. Boulders are not so numerous as on the Gary moraine, yet they are to be seen in nearly every field, there being too little silt or sandy material either in the moraine or on the outlying plain to conceal them. The streams that come down from the high parts of the Coteau des Prairies are so checked on reaching the gentler slopes of the plain to the northeast that they deposit much material on this plain. $\mathbf{A}$ conspicuous illustration is found near Canby, there being about 3 square miles northeast of the village where a sandy and gravelly alluvium has been spread over the narrow plain between Canby Creek and the Lac qui Parle River, each stream having deposited its load. The plain where thus coated has a descent of fully 40 feet in 2 miles from southwest to northeast, and this accounts for the spreading out of the Ceposit over so wide an area. Another deposit of this kind fills the space between tributaries of the Yellow Medicine River near the line of the Chicago \& Northwestern Railway between Porter and Taunton. Aside from these deposits there is generally clayey till in the plain on the north border of the Canby moraine.

Near Revere, in southern Redwood County, there are chains of gravelly knolls which do not line up well either with the Canby moraine or with a later one that lies north of Revere, the Marshall moraine. They also trend toward the ice border instead of parallel with it, as is the habit of eskers. Two chains of knolls diverge from sec. 30, T. 109 N., R. $37 \mathrm{~W}$, one running westward about 2 miles to the southeastern part of sec. 26, T. 109 N., R. 38 W., and the other southwestward about 3 miles to the southwestern part of sec. 35. The knolls are 10 to 20 feet high and some of them are steep sided like segments of an esker; others have gentler slopes and are composed in part of till. They are thus different in material as well as in topography from typical eskers. Other knolls about a mile northeast of Revere are 20 to 25 feet high and composed mainly of till.

A few miles southeast of Revere, in the northern part of Cottonwood County, knolls and short ridges 
of gravel form a disjointed chain about 5 miles in length, from sec. 9, T. 108 N., R. 37 W., to sec. 17, T. 108 N., R. 36 W., in which the chain as a whole, as well as individual ridges, trend east-southeast, about parallel with the border of the Gary morainic system and distant 5 or 6 miles from it. These knolls and ridges range in height from 10 to 30 feet or more and are scattered over a strip fully half a mile wide. They appear to be composed mainly of gravel, and some of the ridges are steep sided, like eskers, and about as narrow. This strip of knolls and ridges has no definite connection with a moraine at either end but stands in a plain that extends from the Gary morainic belt northward to the Cottonwood River. From its west end northward to the Cottonwood Valley at Lamberton the plain is dotted here and there with small till knolls, 10 to 15 feet or less in height, but fully 90 per cent of the surface is flat and featureless. From the east end of the gravelly ridges a conspicuous channel about a quarter of a mile wide leads eastward into southwestern Brown County; this channel seems to have been a line of glacial drainage, but no definite moraine borders it on the north. Its east end is drained by Mound Creek, which turns northeastward near the Brown County line and runs through the St. James moraine to Dotson. It thus does not find continuation as a line of border drainage for that moraine. Apparently it is a feature that antedated the development of the St. James moraine, for the moraine shows a slight protrusion up this channel where it crosses and fills the channel with its knolls.

\section{ST. JAMES MORAINIC SYSTEM}

Extent.-The western limb of the morainic system here named St. James (pls. 2 and 3) has been identified only a little farther northwest than that of the Fairmont system. It appears outside the Marshall morainic system opposite Sunborn, in southern Redwood County, Minn., on the south side of the Cottonwood River. It may be buried under the Marshall system to the northwest. It takes a southeastward course from Sanborn across the northeastern part of T. 108 N., R. 36 W., in Cottonwood County; the central part of T. 108 N., R. 35 W., and the southwest corner of T. 108 N., R. 34 W., in Brown County; and the north edge of T. 107 N., R. 34 W., in Cottonwood County, its course being parallel to and its outer border about 2 miles north of the quartzite ridge that is so prominent in northeastern Cottonwood County. The morainic belt maintains a width of about 2 miles in this portion of its course.

On entering Watonwan County, near the northwest corner, the morainic belt soon becomes split up into narrow, knolly strips separated by nearly level ones, yet it scarcely averages 2 miles in width in its south- eastward course to St. James. It there becomes still more diffuse and changes to a more southward course. St. James Lake seems to lie within the limits of the morainic belt, though this gives it a westward protrusion of more than a mile. From St. James southward into Martin County the morainic belt is separable into constituent knolly strips that have a somewhat different trend from that of the belt as a whole. One just south of St. James runs nearly eastward from St. James Lake for 5 miles, to Bullhead Lake, and there swings southward to meet another knolly strip that comes in from the west across secs. $6,5,8$, and 9, T. 105 N., R. 31 W. This strip then runs southeastward to the corner of the township, and another outside of it crosses secs. $21,28,27,33$, and 34 and dies out at the line of Martin County, 2 miles farther west. The eastern strip continues in rather diffuse form southward for 3 miles, takes an eastward course along the north side of Elm Creek to the southwestern part cf T. 104 N., R. 29 W., and there crosses to the south side of Elm Creek and runs southeastward into Faribault County directly west of Guckeen.

The morainic belt becomes very diffuse and ill defined in eastern Martin County and is represented only by scattered knolls and faint ridges in western Faribault County. It is probable that part of this faintness may be ascribed to ponded waters, as the land here is from 20 to 50 feet lower than the outlet to the south through Union Slough to the Des Moines Valley. The ice border at this time probably passed south of the city of Blue Earth and developed a faint ridge to the southwest in sec. 24, T. 102 N., R. 28 W., and sec. 30, T. 102 N., R. 27 W., and knolls farther west, near Gorman Lake. The ice border probably crossed the East Fork of the Blue Earth River some 3 or 4 miles east of Blue Earth and ran northeastward to a definite morainic ridge that sets in about 9 miles from the city, in sec. 29 , T. 103 N., R. 26 W. This ridge runs northeast about 3 miles to Kanta Lake and there makes an abrupt turn to a course south of east, but a knolly strip runs northward from this turn to the Chicago, Milwaukee, St. Paul \& Pacific Railway midway between Delavan and Easton. The moraine runs eastward to Walnut Lake, a distance of 6 miles. and has a width of about half a mile. Its course beyond Walnut Lake is somewhat problematic. One knolly strip, with some prominent gravelly knolls, runs southward from the west side of the lake about 4 miles to sec. 23, T. 102 N., R. $25 \mathrm{~W}$. There is an extensive swamp east of it through which the East Fork of the Blue Earth River flows southward. This swamp may have been covered by a southward protrusion of the ice at the time the morainic belt was being formed on its west border. But the border then seems to have run northward past the east side of Walnut Lake and 
thence northeastward, along the north side of the Blue Earth River, into Freeborn County. In Freeborn County there are two more or less definite ridges or knolly strips leading northeastward past Freeborn Lake into southeastern Waseca County, which become merged with the great morainic system near New Richland. The morainic belt seems to be merged with the greater one as far north as the Minnesota Valley in southwestern Scott County and is not a definite morainic belt north of that valley.

A strip of knolly land in McLeod County may belong in the St. James morainic system, for it is outside the next later (Marshall) morainic system. The main knolly strip lies south of Buffalo Creek in the southeast rownship of McLeod County but crosses to the north side at Glencoe and runs along and north of the Chicago, Milwaukee, St. Paul \& Pacific Railway from Glencoe to Brownton. It then runs northward past Lakes Marion and Barber to Otter Lake, an expansion of the South Fork of the Crow River west of Hutchinson. It follows the northeast side of this stream to the northwest corner of McLeod County and there becomes merged with the combined Altamont and Gary morainic systems. This strip of knolls ranges in width from a mile or less to 3 or 4 miles. In places the knolls are closely agoregated, but as a rule they are scattered and have considerable level land among them, the knolls occupying scarcely ontfourth of the surface.

A shorter strip of knolls a few miles north of this one, in northeastern McLeod County, is noted in the description of the Fairmont morainic system. It may, however, prove to be more nearly a correlative of the St. James system. It is a definite belt for only $\gamma$ io 10 miles, from Lake Winsted to Silver Lake. The closely aggregated knolls are confined to a strip only half a mile wide, but knolls are scattered widely over the northeastern part of the county as far south as the South Fork of the Crow River. There is a similar tract on the south side from Hutchinson to Biscay, and this tract merges with the knolly strip above mentioned as a correlative of the St. James morainic system. The ice border appears thus to have been rapidly receding across the region from one of these knolly strips to the other, and the time covered in this recession may have been no longer than that embraced in the development of the St. James system. Strict and definite correlation of these isolated strips on the northeast border of the ice lobe with the morainic systems on the southwest side can scarcely be made a1 present.

Topographic features.-From the Cottonwood Valley opposite Sanborn southeastward across the southwest township of Brown County the moraine has a stronger expression than in any other part of its course. There are large knolls, 20 to 40 feet high, among which are numerous small hummocks only 8 to 10 feet high. Ponds also abound among the drift knolls, as well as small marshy basins. Farther east, in the vicinity of Comfrey, the large knolls disappear, and the height of the hummocks is rarely greater than 15 feet and most of them are only 5 to 10 feet. They are also less closely aggregated, and fully half the surface is nearly level. The portion of the moraine in southeastern Brown County and northeastern Cottonwood County is considerably higher on its outer border than on its inner, the altitudes being 1,150 to 1,175 feet and 1,070 to 1,100 feet, respectively. There is thus a rise of 50 to 80 feet in the 2 miles from the inner to the outer border. In Watonwan County, however, there is very little difference in the altitude of the borders.

A short distance beyond the North Fork of the Watonwan River in northwestern Watonwan County the moraine splits, and one member runs past the north side of Cottonwood Lake as a narrow ridged and knolly strip about half a mile wide, leaving a plain half to three-quarters of a mile wide between it and the outer and main member, which passes south of the lake and has a width of nearly a mile. The knolls are 15 to 20 feet high and are numerous enough to give good morainic expression. The altitude in the northwest township of the county is 1,125 to 1,150 feet, but in the vicinity of St. James only a few knolls rise above 1,100 feet, and the lakes and basins are at about 1,075 feet. Few of the knolls reach a height of more than 20 feet, and they are not closely aggregated in the vicinity of St. James or southeastward into Martin County. The tendency to arrangement of the knolly sirips in a trend transverse to that of the moraine as a whole is noted in the description of the course of the morainic system. The strongest expression exhilited by the moraine in Watonwan County is found within 3 miles of the Martin County line. The knolls are closely aggregated in secs. 22, 23, 25, 26, 27, 34, and 36, South Branch Township (T. 105 N., R. $31 \mathrm{~W}$.$) , and are 15$ to 20 feet high. The moraine splits in sec. 27 , one member leading south into sec. 34 and the other east and south through secs. 26, 25, and 36. Only the eastern member continues into Martin County.

A striking feature on the outer border of the morainic belt in northern Martin County is a swampy channel about a quarter of a mile wide which leads southward through the western range of sections in T. 104 N., R. 30 W., past Perch Lake to the Elm Creek Valley. There is now a divide at the south end of Perch Lake between Perch Creek, a tributary of the Watonwan River, and Elm Creek, a tributary of the Blue Earth River. This channel is in line with the 
Middle Chain of Lakes, which extend southward to the State line across central Martin County, and like them is probably in the line of an interglacial river. But it may also in the part north of Elm Creek have served as a line of ice-border drainage at the time the St. James morainic system was formed: In the northward draining part in secs. 6,7 , and 18 it has bluffs 30 to 35 feet high and seems to be fully as low as at the junction with Elm Creek, the barometric reading being 1,075 feet above sea level directly west of Truman. This seems rather low to have been a stream course, and it may prove instead to be the bed of a long lake of which Perch Lake is the shrunken remnant.

The moraine has exceptional strength eastward from Perch Lake across Westford Township and the southwestern part of Nashville Township to the point where it crosses Elm Creek. Some knolls are 40 feet high, and many are 20 to 25 feet. The highest ones are fully 1,150 feet above sea level. The knolls are in chains, and the surface is ridged also. An outer ridge runs through the southern part of secs. 25,26 , 27 , and 28 , and an inner ridge through secs. 17, 20,21, $22,23,26$, and 25, Westford Township, the two being united in sec. 25. There are scattered knolls over much of the northeastern part of the township, some of which rise 15 to 20 feet above bordering level tracts. They occupy from 10 to 25 per cent of the surface, but are most numerous near the moraine.

From the crossing of Elm Creek southeastward to Guckeen, in western Faribault County, the moraine is rather weak and diffuse, with nearly level tracts among the low knolls. Few of the knolls reach 25 feet in height and most of them are 15 feet or less. They are arranged to some extent in chains and narrow strips, in line with the trend of the morainic belt. A strip at Guckeen is near the inner border, and one 2 miles farther south is on the outer border. The outer one is represented by scattered knolls in the south half of Jo Davis Township (T. 102 N., R. 28 W.) and a narrow ridge southwest of Blue Earth, in sec. 30, T. 102 N., R. 27 W. The ridge is only 10 to 15 feet high and less than a quarter of a mile wide, and few of the knolls exceed 15 feet in height. The inner strip seems to die out in a plain at Guckeen. No definite morainic features were found between the Blue Earth River and the East Fork, nor for several miles northeast of the East Fork. A knolly moraine begins in the eastern part of sec. 29, T. 103 N., R. 26 W., and a strip about half a mile wide with knolls 10 to 30 feet high runs northeastward to Kanta Lake and then eastward to Walnut Lake, a distance of 10 miles. A spur with scattered knolls, 10 to 20 feet high, runs from Kanta Lake northward about 4 miles and dies out near the Chicago, Milwaukee, St. Paul \& Pacific
Railway. From the west side of Walnut Lake southward for 4 miles, to sec. 23 , T. 102 N., R. 25 W., an undulating strip about half a mile wide carries a few sharp gravelly knolls, as much as 25 feet in height. But to the east and northeast from Walnut Lake and the large swamp south of it there are only scattered knolls and a very gently undulating surface among them as far as the Freeborn County line, yet these seem to represent the morainic belt.

Two more or less definite knolly strips are present in northwestern Freeborn County, separated by a plain scarcely a mile wide. One passes around the south and east sides of Freeborn Lake; the other passes its west side. The highest knolls stand 25 to 30 feet above the lake but only 15 to 20 feet above the bordering plains. There are numerous basins and also elongated wet tracts between and on each side of the knolly strips, 10 feet or so lower than the border plains, which tend to strengthen the expression of the moraines. The outer ridge from a point near Hartland northward to its junction with the great morainic system east of New Richland assumes greater strength than to the southwest and rises 20 to 30 feet above border plains. The inner ridge is of similar strength from the county line north into New Richland. In the vicinity of the line of Freeborn and Waseca Counties the plain to the west of these morainic ridges makes a westward clescent of about 40 feet in a mile to a plain with gentler slope, but this steep slope is relatively smooth and lacks morainic expression. The Chicago, Milwaukee, St. Paul \& Pacific Railway crosses it in sec. 5, Freeborn Township (T. 104 N., R. 23 W.), and it is plainly discernible for a mile or two farther north.

The knolly strips in McLeod County that are thought to be probable correlatives of the St. James morainic system present usually knolls of gentle slope 10 to 20 feet in height. A few of them are in small clusters, but most of them are isolated and stand in nearly smooth tracts tnat differ but little from the reighboring ground-moraine areas. The most prominent knolls are within 5 miles southwest of Hutchinson, and an area of several square miles is pretty fully oscupied by them. In the narrow strip running from Silver Lake to Winsted Lake the knolls, though relatively numerous, are usually less than 10 feet high. The string of lakes between Brownton and Hutchinson are in basins 10 to 20 feet below the flat tracts and add to the expression of this part of the belt, but lakes are also numerous in bordering flat tracts where knolls are not present.

Character of the drift.-The St. James morainic belt consists mainly of clayey till, with only small pockets of gravel and sand, but some of the prominent knolls, such as those in northeastern Cottonwood County and southwestern Brown County, are com- 
posed largely of gravel. So also are the prominent knolls in northeastern Martin County and those in the well-defined part of the morainic belt in central Faribault County, both west and south of Walnut Lake. Surface boulders are rarely conspicuous, but they are very numerous at the north end of the exposed part of the morainic belt on the Cottonwood River west of Sanborn, over an area of a square mile or more. In the St. James, as in the Fairmont morainic belt, boulders are present on nearly every farm but are rarely so numerous as to be a serious hindrance to cultivation. The linolls have very little silt or silt loam over the till to conceal the boulders, but in many places on the flat tracts the till is coated with 2 to 4 feet of silt and loam, and the boulders are generally covered.

The Wisconsin drift in this morainic belt ranges in thickness from 10 feet or less up to fully 50 feet, being thickest on the prominent knolls. It is usually oxidized to a depth of about 20 feet and presents a yellowish-brown color changing downward to grayish yellow. The unoxidized till is of a pale bluegray color. All the till is highly calcareous except in the leached surface. The depth of leaching is usually less than 5 feet and in places is only 2 or 3 feet.

The pre-Wisconsin drift is composed largely of blue till, as indicated by well records. There are very few places where it is exposed. Water-bearing sand and gravel beds occur in the blue till and in places under it. A few wells whose records are given in WaterSupply Paper 256 are in or near this morainic belt, at St. James, Truman, Blue Earth, and Wells. At Wells the drift is only 125 feet thick; at the other places it is about 200 feet. 'The same paper contains records of wells in McLeod County that show the drift there to average about 300 feet in depth.

Features of inner-border district.-The inner-border district includes the ground moraine between the St. James morainic belt and the moraines and outwash of the Marshall morainic belt. It embraces only a narrow strip, 2 to 5 miles wide, northwest of St. James but expands to much greater width toward the east. The width is 30 to 40 miles at the southeast end of the lobe, where much of Blue Earth County, adjoining parts of Faribault and Waseca Counties, and the northwest corner of Freeborn County are included. There is also a wide area each side of the Minnesota River below Mankato, embracing the greater part of Le Sueur, Nicollet, and Sibley Counties and extending slightly into Scott, Carver, and McLeod Counties. It becomes narrower in passing northwestward across southwestern Meeker, northeastern Renville, southern Kandiyohi, eastern Chippewa, and eastern Swift Counties.

The greater part of this district is a relatively smooth plain of clayey till, with very little coating of sand or silt. There is a conspicuous coating of sand in a narrow strip running northwestward from the South Fork of the Watonwan River to the North Fork in northwestern Watonwan County. East of the South Fork the deposits over the till are relatively thin, usually only 2 or 3 feet thick, and consist mainly of silt or a slightly sandy silt loam. In places the silt is compact and the soil a black gumbo. It is probable that ponded waters of glacial Lake Minnesota (p. 98) covered the southern and southeastern parts of this district as the ice border was melting back to a position that would permit drainage to the Minnesota Valley, and the sand and silt are the products of such ponding. There is, however, a slight coating of silt on the flat till areas in the northeastern part of this district where there is little or no evidence of general ponding. Such deposits may be referable to local ponding or imperfect drainage on the border of the ice. They may also be due in part to slope wash into depressions subsequent to the retreat of the ice. In fact, there is still going on more or less wash of this sort in places where drainage lines are scarce.

In the southeastern part of the district, where the waters of glacial Lake Minnesota are thought to have been present for a brief time, the surface is generally flat. But there are a notable number of basins, some of which are occupied by lakes and others by marshes, which give the plain considerable diversity. These depressions are thought to be the unfilled parts of interglacial drainage lines, for the Wisconsin drift is a thin deposit here. It may not exceed 10 or 15 feet in average thickness. The depressions are nearly as numerous here as in the northeastern part of the district, where ponding seems not to have occurred. The ponded waters thus seem to have done very little filling of the basins, as would be natural if they had covered the area for only a brief time. The basins are exceptionally numerous and large in the northeast corner of Blue Earth County and the neighboring part of Le Sueur County, where they occupy one-third to onehalf the surface. It was in this part of the district that recession of the ice border permitted the waters ponded in the southern part to be drained northward to the Minnesota Valley. This part probably experienced little or no ponding. But the number and size of the basins seems to have no relation to the ponding.

A narrow strip of the ground moraine in Waseca, Le Sueur, and Scott Counties immediately west of the combined Altamont and Gary morainic systems has the features of an overridden terminal moraine, the surface being billowy or rolling, but with smooth slopes, such as might result from the encroachment of the ice sheet on the morainic belt. This billowy strip extends as far west as Janesville and the outlet of Lake Elysian, in northwestern Waseca County, 5 or 6 miles inside the border of the unmodified part 
of the morainic system. It extends to the Minnesota Valley opposite St. Peter and about to Cleveland, but a plain extends to the moraine from Cleveland northward to the Minnesota Valley at Belle Plaine. The features of this strip are so distinctly different from those of the unmodified moraine that no difficulty was experienced in mapping its eastern limits. It is different also from the zone of gradation from a moraine to a till plain, in which morainic features gradually die out in a plain, for the overridden prominences are about as numerous as in the well-defined moraine, and numerous basins are inclosed among them. It is also significant that the rounding of prominences is more definite than the smoothing of the depressions. In places the low areas still exhibit the irregularities of an unmodified moraine. A conspicuous illustration is found in a low strip about a mile wide that runs from the middle part of Lake Elysian for 3 or 4 miles eastward to the unmodified moraine. Its small hummocks and basins are in striking contrast with the smooth slopes of the prominences to the north and south of the valley-like depression.

There are a few places in this extensive groundmoraine area, remote from any well-defined moraine, where small knolly areas are to be seen. Thus the southwest township of Blue Earth County is named Pleasant Mound because of a narrow strip of gravelly hills 50 to 75 feet in height and about a mile in length situated in the southeastern part of the township, mainly along the line of secs. 25 and 26 but extending slightly beyond both north and south. A larger knolly area, but not so high, runs north from the north end of Jackson Lake for about 2 miles, across secs. 7 and 6, T. 105 N., R. 27 W., its north end being about 3 miles southeast of Vernon Center, Blue Earti County. This also is somewhat gravelly, and the knolls are 20 to 30 feet or more in height. The strip is about half a mile wide.

Near Grogan, in Watonwan County, is a narrow gravel ridge about $11 / 2$ miles long and only one-eighth mile or less in width, running nearly due south across the east side of sec. 33, Riverdale Township, and sec. 4, Rosendale Township. It stands about 20 feet higher than the bordering plains, or about 1,070 feet above sea level. It is rather broad and flat for an esker, but may fall in that class. It appears to consist entirely of gravel and sand. The surface is sandy all around this ridge, and the sand is drifted in places into low dunes. The sand was probably deposited here in the bed of glacial Lake Minnesota by streams coming in from the northwest along the ice border. The surface is, however, only 1,050 to 1,075 feet above sea level, or 75 to 100 feet lower than the southward sutlet of Lake Minnesota through Union Slough. A few low gravelly knolls were noted in this sandy area, but till is commonly found beneath a thin coating of sand.

There are very few knolls of note on the plain north of the Minnesota Valley outside of the Marshall morainic belt in Nicollet, Sibley, Renville, McLeod, Meeker, and Kandiyohi Counties. Here and there a small knoll covering 10 acres or less rises 10 to 20 feet above the plain. Some of these contain gravel as well as till. In McLeod County the knolls are sufficiently numerous to give some support to the view that they mark a halt in the ice border which may perhaps be correlated with the St. James morainic belt.

Deep drilling at Belle Plaine many years ago brought to light the presence of a very deep preglacial valley, with its rock floor only about 500 feet above sea level. The course of this valley seems to be indicated for a few miles southwest from Belle Plaine by a depression in the ground moraine in southwestern Scott County and northwestern Le Sueur County. The bottom of the depression is about 900 feet above sea level, but on each side the altitude is 975 to 990 feet. The depression is about 3 miles wide. The present Minnesota River has cut only about halfway down to the level of the preglacial valley floor, or to about 700 feet above sea level, in this part of its course. The discussion of the filling of the Minnesota Valley by drift and by outwash and of its opening to the present depth is taken up to better advantage in a later section.

Relation of glacial Lake Minnesota to St. James morainic system.-The glacial lake later named Lake Minnesota was first brought to notice by Upham ${ }^{5}$ in 1881. The lake was held in by an ice barrier at the north and discharged southward through Union Slough, in Kossuth County, Iowa, to the East Des Moines River. The lake was described more fully in a later report, ${ }^{6}$ in which reference was made to the St. James moraine. This moraine, however, was mapped by Upham only in part of Faribault County and was correlated with the Kiester Hills, in the southeastern part of the county. which it now appears are a part of the Gary morainic system, instead of the St. James. The alitude of the lake is given as approximately 1,150 feet above sea level. It was thus high enough to cause ponding along the ice border throughout the course of the morainic belt in Faribault, Martin, and Watonwan Counties, and possibly in Cottonwood and Brown Counties. The ponded strip, however, was very narrow except in Faribault County, for within 1 to 5 miles outside the moraine in the part to the west the surface rises more than 1,150 feet above sea level. It is also above 1,150 feet along the border of the moraine in Freeborn and Waseca Counties.

- Upham, Warren, Minnesota Geol. and Nat. Hist. Survey Ninth Ann. Rept., p. 341, 1881.

- Upham, Warren, Geology of Minnesota. vol. 1, pp. 460-462, 1884. 
But no sandy or gravelly outwash was found on the border of this higher part of the morainic belt. The discharge from the melting ice thus seems to have gone almost entirely into this lake.

The name Lake Minnesota, which appears on the maps in Upham's monograph on Lake Agassiz, ${ }^{7}$ was given under the supposition that the lake covered a part of the Minnesota Valley at its most expanded stage. But this now appears very doubtful, for the ice lobe was draining northeastward into the lower course of the Minnesota, as the ice border melted back toward the great bend at Mankato. The ponding appears to have occurred only on the south border of the ice lobe and to have lasted only until the ice border had shrunk away from the great morainic system at the southeast end of the lobe far enough to permit the drainage to run northward to the Minnesota Valley. It was suggested by $\mathrm{Upham}^{8}$ that the first outlet, opened at a lower level than the southward outlet through Union Slough, was one into the Cannon River Valley in the vicinity of Elysian and Waterville, at an altitude of about 1,075 feet. This outlet seems to have served as a line of glacial drainage while the ice was still pressing against the western edge of the great morainic system at the southeast end of the ice lobe. Whether it served later as a line of discharge for ponded waters on the south and east borders of the ice lobe has not been determined. Upham interpreted the ice to have shrunk almost entirely from south to north, but this interpretation is now found to be inconsistent with the distribution of moraines in the Minnesota River drainage basin. These moraines show that the ice persisted along the axis of the drainage basin above Mankato, after it had shrunk away from the district to the north as well as that to the south of the valley.

Upham states that the exact boundary of the lake can probably be traced, with the aid of leveling, along considerable portions of its landward shores, by beach deposits of gravel and sand. These features are likely, however, to be faint and discontinuous, and accurate tracing may not be feasible until good topographic maps with small contour interval are available. The only place where the present writer noted ridges of sandy gravel of lake-beach type is on the east side of the East Fork of the Blue Earth River in secs. 25 and 36, T. 102 N., R. 25 W., and sec. 1, T. 101 N., R. $25 \mathrm{~W}$., a strip about 3 miles in length. The low sandy ridges 5 or 6 feet high are tied onto larger knolls 15 to 20 feet high that seem to be glacial features. One of these knolls in the northern part of sec. 25 is notched on its west slope, apparently by

\footnotetext{
7 Upham, Warren, The glacial Lake Agassiz: U. S. Geol. Survey Mon. 25, pls. 3, 9, 14, 1896.

Upham, Warren, Geology of Minnesota, vol. 1, p. 461, footnote, 1884.

$67665-32-8$
}

wave action. The neighboring part of the East Fork Valley and also the valley of Kiester Creek for 2 or 3 miles of its lower course have clay deposits that seem likely to have been laid down in the ponded waters under discussion. The lake appears to have been narrow as far down the East Fork Valley as the township corners 2 miles east of Frost, perhaps not more than 2 miles in average width. But from that point westward past the main Blue Earth River it had wide expansion. It may have extended slightly into Iowa, westward from Rake, but knolls on the Minnesota side of the line near Elmore, as well as those on the Iowa side, probably stood above it. Much of the southwest township of Faribault County seems to have stood above the lake, and there was only a narrow strip of ponded waters farther west. The area of ponded waters is estimated to have been only 200 to 250 square miles at the time the St. James morainic system was being formed. This is about onefourth the size estimated by Upham, who assumed that the lake extended westward into Yellow Medicine County and had a width of 5 miles or more. In all probability the ice at that time was covering the parts of Yellow Medicine and Lyon Counties that are below an altitude of 1,150 feet, the level of glacial Lake Minnesota. That ponding did not occur in those counties at the time Jater moraines were being formed is shown by the presence of border drainage channels described below.

The small size of the outlet channel through Union Slough, scarcely a quarter of a mile in average width and 15 to 25 feet in depth, is consistent with the interpretation that only a small part of the ice front was draining through it. Probably part of the excavation of this channel preceded the ponding of waters and was effected by a stream discharging directly from the ice as its border receded toward the head or north end of the channel.

The small amount of sediment on the bed of the lake is also suggestive either of brief duration of the lake or of but a small tributary drainage from the edge of the ice. There is generally 2 or 3 feet of silt loam above the till, and rarely more than 5 feet.

\section{MARSHALL MORAINE}

Extent.-The Marshall moraine was named by the writer from the village of Marshall, the county seat of Lyon County, Minn., which stands on it. (See pls. 2 and 3.) It is combined with later moraines in eastern South Dakota as far south as the southern edge of Roberts County. It there becomes a distinct belt and follows the southwest side of Whetstone Creek from a point near Corona to Milbank. It then takes a more southerly course and lies along the west side of the State line for several miles before crossing into 
Minnesota. The Great Northern Railway and Minneapolis \& St. Louis Railroad pass over it just west of the State line. It surrounds Salt Lake, which lies in both States about 3 miles southwest of Marietta, Minn., and bears east of south through Tps. 117 and 1.16 N., R. 46 W., in Lac qui Parle County, Mim. Its course is then nearly due southeast across western Yellow Medicine County and northwestern Lyon County to Marshall, a distance of fully 35 miles. It lies north of the Chicago \& Northwestern Railway as far as Minneota, but that railway is on the moraine from Minneota to Marshall. A shurt distance beyond Marshall the moraine comes to the north side of the Cottonwood River, and it is followed by that stream across Redwood County into western Brown County. The river there cuts through it, and the moraine continues in a course south of east across the Little Cottonwood Valley to the North Branch of the North Fork of the Watonwan River in northern Watonwan County and then follows that stream, the North Fork, and the main Watonwan to the Blue Earth River near Garden City. Its course is then northward along the west side of the Blue Earth River to the Minnesota Valley, just above the city of Mankato.

Aside from the main moraine there is an inner member in Brown County, which has a strikingly different course. It runs northeastward, directly away from the main moraine, crossing the Cottonwood River above Leavenworth and continuing to Sleepy Eye. It there doubles abruptly to a southeast course, crosses the Cottonwood and Little Cottonwood Valleys, runs past the southeast end of Lake Hanska to the Watonwan Valley above Madelia, and takes the place of the main belt for a few miles. A short distance east of Madelia a similar belt sets in north of the main belt and runs eastward to Lake Crystal. It is then merged with the main belt as far as the Minnesota Valley.

The main belt throughout much of the course outlined has a width between 1 and 2 miles. The inner member has a general width somewhat less than a mile.

On the north side of the Minnesota Valley there is a break in the moraine for a few miles, perhaps because of removal by the opening of so wide a valley. But near Courtland it appears with a double phase, and two definite ridges run side by side northwestward across western Nicollet County. They are crossed by the Minneapolis \& St. Louis Railroad between Klossner and Lafayette. In southwestern Sibley County the moraine is indistinct, but in eastern Renville County, from Wellington nearly to Bird Island, it is well defined. It is split up into two or more ridges for part of this course. It is exceptionally strong in T. 114 N., R. 33 W., being about 2 miles wide and showing closely aggregated knolls. The moraine seems to find a continuation in a series of slender and disjointed ridges, which cross northern Renville County in a course somewhat north of west, cut across the southwest township of Kandiyohi County, and run to Clara City. Morainic features are less continuous and definite beyond this place, but it is probable that the ice at this time covered nearly all of Chippewa County and formed the moraine that lies along the south side of the Great Northern Railway between De Graff and Benson. It has not been identified beyond Benson.

Topographic features.-Along the greater part of its course this morainic belt displays a gentle swell and sag topography, in which the swells are from 10 to 30 feet above the depressions among them. A few gravelly knolls occur along it which have steeper slopes and rise to heights of 40 feet or more. In the part north of the Minnesota Valley the topographic expression is more variable than on the south side of the valley. In places there are only scattered knolls or clusters and chains of knolls with flat surface all around them. In only a few places is the width as great as is commonly found south of the valley, and the knolly strips are only a quarter to half a mile wide. In places two or more such narrow strips occur, with narrow intervening plains.

The range in altitude is rather slight, the highest points being but little above 1,200 feet and the lowest but little below 1,000 feet. There is a very gradual ciescent from northwest to southeast, the lowest part being at the southeast end of the morainic loop. The parts that rise above 1,200 feet are northwest of Marshall.

Character of the drift.-The drift is very largely a clayey till, and the surface carries only a moderate number of boulders. A few short strips of gravelly drift were noted. One is along the Cottonwood Valley from Heckman eastward nearly to the line of Iyon and Redwood Counties. This lies outside the main part of the morainic belt and is separated from it by a narrow drainage channel. Loose-textured drift also occurs for a few miles in western Brown County, extending from the vicinity of Dotson westward to the Cottonwood Valley. Another short strip of gravelly drift is found in northern Watonwan County westward from La Salle. East of La Salle the main moraine seems to be buried in or give place to an outwash gravel plain as far down as the junction of the North and South Forks of the Watonwan River, near Madelia. In this interval the inner member is present along the north border of the gravel plain. On the main moraine in Blue Earth County there is considerable surface sand that suggests ponding of water at the end of the ice lobe. Very few pebbles occur in the sand. In the part north of the Minnesota 
Valley there are a few gravelly knolls. Some of these knolls are in definite morainic strips, but others appear us isolated knolls or clusters of knolls in the bordering plains. A considerable number of them have been opened for road material. Usually some till is associated with the gravel, so that the amount of material suitable for road use is generally only a small part of the knoll.

Boulders are very conspicuous in a few places on the morainic knolls and the depressions among them. They are exceptionally numerous in an area of 7 or 8 square miles in northern Winfield Township ( $T$. 116 N., R. 35 W.), in Renville County and the adjacent edge of Kandiyohi County. The moraine there is weaker than in neighboring sections to the northvest and the southeast, which are not so plentifully supplied with boulders. Boulders are very numerous, also, in southern Martinsburg Township (T. 114 N., R. 32 W.), in eastern Renville County, over an area of about 2 square miles. But most of the moraine carries only a moderate number of surface boulders, and only here and there do they greatly hinder the cultivation of the land.

The drift is thick along the entire course of this moraine, both north and south of the Minnesota Valley. It is 100 to 300 feet thick in southwestern Yellow Medicine County, but in Lyon County the thickness in the vicinity of this moraine is generally less than 100 feet. In southwestern Redwood County it is generally between 100 and 200 feet, yet there are places where the Cretaceous sandstones are near the surface. There is an outcrop between Lamberton and Revere, but at Lamberton the drift is about 200 feet thick. At Sanborn the drift is about 200 feet thick, but the Cretaceous rocks crop out along the Cottonwood River a few miles below this village. In Brown County there are outcrops of the Cretaceous in the vicinity of Springfield, but generally the drift is 100 to 200 feet thick. In Watonwan County the drift in the vicinity of this moraine is generally nearly 200 feet thick; in northwestern Blue Earth County, 100 to 150 feet. In Nicollet County the thickness ranges from less than 100 feet to nearly 300 feet. In Sibley County it is 400 feet at Winthrop and 275 feet at Gibbon. In Renville County a thickness of 438 feet was found at Hector, 340 feet at Buffalo Lake, 280 feet at Bird Island, 297 feet at Olivia, and 202 feet at Fairfax. In Chippewa County rock is found nearly up to the level of the uplands in places near the Minnesota Valley, but the drift a few miles back is 150 to 200 feet thick, and toward the northeastern part of the county it becomes still thicker. In southeastern Swift County the drift probably has a general thickness of more than 200 feet. At Benson it is at least 170 feet thick, for the village water supply is obtained from gravel deposits at that depth.
The Wisconsin drift probably embraces only 25 to 50 feet of the thick deposits along the line of this moraine. Exposures of the older drift are rare, however, and are found chiefly in the stream bluffs. One of these was noted on the range-line road a mile southwest of Springfield, where the road rises to the south bluff of the Cottonwood River. Beneath the Wisconsin drift, which is here 15 feet thick, there is a darkcolored gummy soil, which is in places disturbed and involved in the overlying till. The pre-Wisconsin till below shows a deeply weathered surface of reddishbrown color changing below to a seamed and indurated brown till. In exposures northwest of New Ulm, where the Minneapolis \& St. Louis Railroad runs up from the Minnesota Valley, there are deep cuts in which the drift is nearly all pre-Wisconsin. One exposure half a mile from the river bluff shows a black till of Nebraskan aspect, with included beds of sandy gravel, which extends up from the base of the cut to a height of 50 feet. Above this is a brown till that cleaves in vertical columns like typical Kansan drift. It extends to the top of the cut and has a thickness of about 25 feet. The Wisconsin till here lies farther up on the slope of the ravine that the railroad ascends. Nearer the river the Wisconsin till comes down to a lower level, apparently filling an interglacial valley. Exposures of two pre-Wisconsin tills outside this moraine near Rapidan are described in connection with the older drifts (p. 17).

The gravel beds associated with the Wisconsin drift are of fresh gray color, strikingly in contrast with the deeply stained gravel found with the older drifts. On the brow of the bluffs of the Minnesota River in the vicinity of New Ulm there are several good exposures of the fresh gravel both under and in the Wisconsin till, and the thickness of the till and gravel together is about 50 feet.

Outwash and border drainage.-The plain immediately outside of the Marshall moraine in Grant County, S. Dak., has a light coating of sand over the till, which seems to indicate that there was more or less ponding of water along that part of the ice border. Near the Minnesota State line a definite outwash plain of sandy gravel sets in, which borders the moraine through much of its course across Lac qui Parle County, Minn. It ranges in width from about a mile to 3 miles or more. It is widest in T. $117 \mathrm{~N}$., R. $46 \mathrm{~W}$., and becomes narrower toward the south in T. 116 N., R. 46 W., in the southeastern part of which the outwash becomes thin and patchy. Across Yellow Medicine County and as far as the Cottonwood Valley directly south of Marshall in Lyon County there is a narrow plain that was probably utilized as a border drainage course for that part of the ice and for the discharge for the waters that formed the outwash plain in Lac qui Parle County, but drainage fea- 
tures along it are rather vague. In places a low bluff can be detected along the landward side, and in places the plain carries a small deposit of sandy materialfeatures that support this interpretation.

The Cottonwood Valley from the vicinity of Marshall southeastward across Redwood County into western Brown County afforded a line of discharge for glacial waters along the immediate border of the moraine, and there is a thin deposit of sandy gravel along much of its course. The river now turns northeastward across the Marshall moraine in western Brown County, but the line of glacial drainage continued southeastward past Dotson to the Little Cottonwood Valley. Farther east, as indicated on Plate 2, the outwash features and glacial drainage show considerable complication. There is a swampy channel running southeastward from the Little Cottonwood Valley to the valley of the North Fork of the Watonwan on the outer border of the main morainic ridge. Another channel leaves the Little Cottonwood Valley a few miles farther down and runs to Hanska Lake. This lake seems to be occupying a glacial drainage channel, which continued from the southeast end of the lake to the Watonwan Valley east of La Salle. There is a conspicuous outwash deposit on the Watonwan River between La Salle and Madelia. Sandy gravel deposits occur along the Cottonwood Valley east and south of Sleepy Eye and extend across to the Little Cottonwood Valley and the northwest end of Hanska Lake. They appear to be the product of ice-border drainage at the time the inner ridge was being formed, for they are mainly on the border of that ridge both southwest and southeast of Sleepy Eye.

There is very little sandy gravel outwash along the Watonwan Valley below Madelia. This fact and the presence of some sand on the Marshall moraine in northwestern Blue Earth County suggest that there was more or less ponding of water along that part of the ice border. Yet it appears certain that the Minnesota Valley had been uncovered at that time below the mouth of the Watonwan, so as to afford unobstructed discharge through it to the Mississippi at Fort Snelling. The ponding may thus have been of very slight extent.

Outwash and glacial drainage in Minnesota Valley.--In the part of the Minnesota Valley leading north from Mankato to Carver there are conspicuous deposits of glacial gravel on broad, high terraces only a few feet lower than the bordering till plains. These deposits may have been laid down mainly in the course of the recession of the ice border up the valley and thus may have antedated the Marshall moraine. But it is probable that the glacial drainage at the time of the development of the Marshall moraine was about at the level of the highest terrace, and this drainage may have given the gravel deposits the relatively smooth surface they now present. Prominences left as the ice retreated up the valley may thus have been cut away and depressions in the outwash filled up as a result of the continuation of glacial drainage down the valley. As the same process would have been continued as the ice border receded up the valley beyond the place where the Marshall moraine crosses, it is not an easy matter to determine just what had been accomplished in the way of grading of the high plains or terraces at this particular time. The lack of definite outwash in the lower course of the Watonwan River on the border of the Marshall moraine serves to increase the difficulties of correlation of the moraine with terraces on the Minnesota Valley below. The excavation of the Minnesota Valley was probably very shallow all through the period of glacial drainage and well into the period of the drainage from glacial Lake Agassiz, because of the rock barrier between St. Paul and Fort Snelling, which was eventually cut away by the outlet of Lake Agassiz, as shown below. The valley was deepened at least 100 feet after this rock barrier was removed.

Features of inner-border district.-Between the Marshall moraine and the next younger or Antelope moraine there is a till plain which is only 2 to 4 miles wide in Lac qui Parle and Yellow Medicine Counties, but which in Lyon County increases to 8 or 9 miles at the east border and in central Redwood County reaches about 15 miles. It has very ferr knolls or striking topographic features but is a gently undulating till tract.

In eastern Redwood County some complexity is found, there being slender strips of knolly land a quarter of a mile or less in width, that may mark brief halts of the ice border in its recession. One strip runs from a point near Seaforth southeastward past Clements nearly to Cobden, a distance of fully 25 miles. Another strip leaves the Redwood Valley midway between Seaforth and Redwood Falls and runs southeastward nearly to Morgan at a distance from the other knolly strip of 3 to 4 miles. Each of these strips has many gravelly knolls, some of which are 25 feet or more in height, that put them in striking contrast with the flat till tracts that border them. Neither of these strips is traceable to the Minnesota Valley, but each dies out in a plain some miles back from the river. At the west they connect with the Antelope moraine in such a way as to suggest that they should be included with it. There is, however, a diefinite continuation of the Antelope moraine past their points of connection with it through Redwood Falls to the Minnesota Valley opposite Franklin.

Beyond the ends of these slender ridges there is a till plain in northern Brown County and northwestern 
Blue Earth County, extending to the Minnesota Valley. A similar plain is present on the north side of the river from a point opposite New Ulm to Franklin. A narrow plain lies between the Marshall and Antelope moraines in Renville and Chippewa Counties, the average width being 10 miles or less. On the level tracts north of the river there is less contrast in topography with the moraines on each side than south of the river, because the moraines on the south side are much sironger features than those on the north.

The till on these level tracts is generally very clayey, with but a few boulders in it or on the surface. Over rnuch of the surface there is a rich black soil.

\section{ANTELOPE MORAINE}

Extent.-The next moraine was partly traced by Upham, and its course across Lac qui Parle and Yellow Medicine Counties was indicated on his maps. ${ }^{9}$ The name Antelope, introduced by Chamberlin, ${ }^{10}$ was taken from the local range of hills, known as the Antelope Hills. It is a distinct moraine for only a short distance into South Dakota, where it becomes merged with other moraines, but it is traceable eastward in Minnesota far beyond the limits shown by Upham. (See pls. 2 and 3.)

The northwest end of the distinct moraine is in a range of gravelly hills in eastern Grant County, S. Dak., known as the Mount Tom Range, which runs from the North Fork of the Yellow Bank River to the South Fork, a distance of 2 or 3 miles, and has a general width of scarcely half a mile. With this should probably be included a less prominent strip of moraine on the east, separated from it by a very narrow plain. There is a similar double ridge with narrow intervening plain through much of its course across western Lac qui Parle County, Minn. In the southern part of the county the prominent hills are in the eastern member. In Yellow Medicine County there is a main outer member with a partial development of a weak inner one. The moraine swings around to the east in western Yellow Medicine County and is crossed by the Yellow Medicine River in the northern part of Lyon County and by the Great Northern Railway between Green Valley and Cottonwood. Just west of this railroad it is split into several narrow strips of knolly land with intervening level strips, but east of the railroad it is united into a single morainic belt 2 or 3 miles wide. It follows the north side of the Redwood River as a united belt nearly to Seaforth. Farther east slender strips of knolly land part from the main belt and bear southeastward through the outer border plain into the eastern part of Redwood

\footnotetext{
- Upham, Warren, Geology of Minnesota, vol. 1, pls. 27, 29, 1884.
}

${ }_{10}$ Chamberlin, T. C., U. S. Geol. Survey Third Ann. Rept., pp. 388, $393,1883$.
County, where they die out without reaching the Minnesota Valley. The main part follows down the Redwood Valley to Redwood Falls and continues eastward to the Minnesota Valley near the east line of Redwood County. This is the end of a definite morainic loop, for the moraine doubles back to the northwest on the north side of the valley.

The moraine is well displayed on the river blufts in the vicinity of Franklin but soon bears away northward and crosses Beaver Creek about 3 miles from the river. It follows the west side of the creek northward a few miles and then turns abruptly westward and dies out about 4 miles southeast of Renville. An inner member lies a short.distance west of the outer or main member from Beaver Creek northwestward. The moraine is more fragmentary from the vicinity of Renville northwestward than in the remainder of its course, and there is some uncertainty as to its equivalents. A slender morainic strip along the south side of Chetamba Creek in the northwestern part of Renville County may be a partial equivalent. There are short strips of knolly land west and north of Maynard that may also be correlated with it. A slender moraine that runs from a point near Mandt northward past Danvers, a distance of nearly 20 miles, may fall in this string, though it seems to be nearer the axis of the lobe than those in the vicinity of Maynard and thus perhaps somewhat younger.

Topographic features.-The part of this morainic belt that Upham mapped as the Antelope Hills has a stronger topographic expression than the part he left unmapped. Some of the knolls in the Mount Tom Range are 75 feet in height and very steep. There are a few fully as high and sharp in the southwestern part of Lac qui Parle County, where the name Antelope Hills was applied by the settlers. Many knolls 25 feet or more in height occur all along the part mapped by Upham. As the moraine swings eastward in Yellow Medicine County, it takes on a swell and sag topography and exhibits few sharp knolls. The swells rise 10 to 20 feet or more above the sags, and nearly all the surface is undulating. The slender outlying strips in eastern Redwood County have sharp knolls. North of the Minnesota Valley the morainic strips have less strength as a rule than on the south side, yet they are distinctly more undulating than the bordering till plains. Some of the knolls that contain gravel are sharp and rise 25 feet or more above the bordering swales. But most of the knolls have gentle slopes and are only 10 to 20 feet in height.

A striking feature of this morainic belt is the narrow plain or swale that separates its two members in Lac qui Parle County. It is practically continuous along the entire length of the moraine in this county, a distance of nearly 30 miles. A few sharp, gravelly 
knolls stand in it in the vicinity of Nassau, but generally it is as flat and open as a stream valley. It is occupied by the South Fork of the Yellow Bank River for about 5 miles and by tributaries of the West Branch of the Lac qui Parle River for nearly 10 miles. The interval between the Yellow Bank and Lac qui Parle Rivers, about 8 miles, was a swamp; which has a drainage ditch that discharges into the Lac qui Parle. This ditch heads within a mile of the Yellow Bank River but drains in the opposite direction. This feature and the northward drainage of Florida Creek through it from the southern part of the county indicates that the swale has ups and downs in its course and not a continuous southward descent. It is therefore probably not a line of iceborder drainage. This interpretation seems borne out by the character of the drift along the swale. It is generally a clayey till, and what little sand and gravel there is occurs in the form of knolls. The swale thus appears to be a line of division in the moraine, formed, perhaps, beneath the ice rather than at its edge.

Character of the drift.-The Mount Tom Range, in Grant County, S. Dak., and the prominent part of the Antelope Hills, in Lac qui Parle County, Minn., contain much gravelly material, but the greater part of the morainic belt is a somewhat clayey till, with only a moderate number of boulders in it or on the surface. Gravelly knolls are numerous in the slender outlying morainic strips in eastern Redwood County and in the part of the moraine west of Beaver Creek in Renville County, but as a rule the part north of the Minnesota Valley is a rather clayey till.

Outwash and border drainage.-A definite outwash plain of sandy gravel lies outside the Mount Tom Range of morainic hills, filling the space of about 3 miles between the North and South Forks of the Yellow Bank River, mainly in Grant County, S. Dak. It is a mile or more in width. For about 12 miles south, including the part of the border near Nassau and Marietta, there is no distinct outwash. But at the valley of the West Branch of the Lac qui Parle River, in the southeastern part of T. 117 N., R. 46 W., a sandy-gravel outwash deposit sets in which borders the moraine for about 5 miles to the south. Beyond this is a space of about 10 miles in which the moraine has little or no outwash on its outer border. At the South Branch of the Lac qui Parle River there is a small amount of outwash, and a definite border drainage channel there sets in which follows the moraine past the Yellow Medicine River to the Redwood River and down its valley for 20 miles, to the vicinity of Seaforth, its entire length being thus about 50 miles. The average width of the channel is about a mile. Where unoccupied by present drainage lines it is usually swampy. The border drainage that cut this definite channel seems to have spread out as it left the Redwood Valley near Seaforth, as no channel was noted farther east. Nor was any outwash sand or gravel observed along any of the slender morainic strips in eastern Redwood County.

It is probable that there was free discharge for the drainage from the end of the lobe down to the Minnesota Valley. A definite old channel appears south of the present deep valley of the Minnesota, where this moraine comes to the south bluff of the river, and is traceable from sec. 22 across secs. 23, 26, and 25, i. 112 N., R. 34 W., to the brow of the river bluff. This channel was probably formed at the time the ice border began melting back from the moraine. It is about 25 feet below the level of the bordering upland and 175 feet above the present level of the Minnesota River. It thus seems to represent the beginning of the drainage from this place down the Minnesota Valley.

A narrow strip of sandy gravel follows the south side of Chetamba Creek in northwestern Renville County, on the outer border of the moraine. The bedding dips northward away from the moraine, so the deposit seems to be an outwash from the moraine. The strips of moraine farther north, in Chippewa and Swift Counties, do not seem to have either outwash or border drainage connected with them. The morainic strip that passes through Danvers runs into an outwash plain at the north, but this outwash seems to have been laid down at a later time, when ihe ice was forming a stronger moraine a few miles to the northwest.

\section{MORAINES AND ASSOCIATED FEATURES BETWEEN ANTELOPE MORAINE AND MINNESOTA VALLEY}

In a small area in Roberts and Grant Counties, S. Dak., and Lac qui Parle, Yellow Medicine, Chippewa, and Swift Counties, Minn., there are several slender morainic strips that make less complete loops than the moraines previously described. Their position and incompleteness may be seen by reference to Plates 2 and 3. The ice border seems to have held a pretty steady position on the southwest side of Big Stone Lake and for a few miles into Lac qui Parle County while receding over a considerable area near the end of the lobe. In the course of this recession halts of sufficient length were made to develop these slender and relatively weak morainic strips. As the intervening till plains have knolls or clusters of knolls scattered over them, the usual pronounced contrast between the morainic belts and the till plains is lacking.

The outermost of these morainic strips is distinctly traceable from the point where it parts from the compound moraine, in western Lac qui Parle County, in T. 118 N., R. 45 W., southeastward into central Yel- 
low Medicine County, where it dies out in a till plain a. few miles southwest of Clarkfield. It does not have a definite outwash or a border drainage course along its outer border, such as is so conspicuous on the adjacent section of the Antelope moraine. It is composed very largely of clayey till, and most of the knolls have gentle slopes. Some of them are lined up in definite chains 1 to 2 miles or more in length, whose trend is diagonal to that of the belt of which they are a part, but as a rule there is little or no system in their distribution, and they vary from a closely aggregated to a somewhat scattered arrangement.

Another undulating strip of similar sort runs southeastward through Madison and passes just south of Mawson and Boyd to Clarkfield, a short distance beyond which it dies out in a till plain. There are, however, small areas with undulating surface a few miles farther southeast, in the vicinity of Wood Lake and Echo, that may mark the continuation of the ice border. A more distinct moraine sets in about 3 miles north of Clarkfield and is distinctly traceable for about 30 miles, its southeast end being a short distance east of Belview, in northern Redwood County. It there marks the end of a morainic loop that crosses to the north side of the Minnesota Valley and doubles back to the northwest along the north bluff as far up as Montevideo. There are two ridges near the end of this lobe. One runs east from the north edge of Belview 2 miles and then northward to the Minnesota bluff in sec. 35, Swede Forest Township, with scattered knolls a mile or more farther east. The other follows the south bluff of the Minnesota closely from the mouth of the Yellow Medicine River about 10 miles southeast to sec. 27, Swede Forest Township. This is the main member and is about a mile in width along much of its course. 'This belt has a stronger expression than the one that comes into Clarkfield from the northwest. Many of the knolls are 25 feet or more in height, with rather steep slopes and closely aggregated.

There are other narrow strips of undulating land in Lac qui Parle County north of those already noted. One passes 1 to 2 miles north of Madison, runs eastward to the Minnesota Valley near the mouth of the Lac qui Parle River, and crosses to the south side of that stream just above the village of Lac qui Parle. This strip is less than a mile in general width and has a very mild expression, with a surface but little more undulating than that of the bordering till plains. A similar strip that runs parallel with this about 4 miles farther north is traceable about to the Minnesota Valley opposite the middle part of Lac qui Parle Lake. Neither of these strips shows distinct border drainage features or outwash. Each is composed of very clayey till similar to that of the border till plains.
North of the Minnesota Valley in western Chippewa County and southern Swift County there is a series of parallel morainic strips separated by narrow strips of outwash, as may be seen by reference to the glacial map. These morainic strips were formed in succession from east to west by a shrinking ice lobe. There are four of these ridged strips west of the Chippewa River. Their position in reference to the Minnesota Valley is similar to that of the two slender undulating strips on the south side of the valley noted in the preceding paragraph. The outer one may, however, find its continuation down the north side of the valley from Montevideo and be correlated with the moraine on the south side that comes to the Minnesota Valley near Belview.

The morainic strips just mentioned seem to pertain to a very narrow ice tongue that was gradually reduced until it completely melted before the ice sheet read. vanced with a broader front to a strong moraine that traverses southern Big Stone County and northwestern Swift County, as indicated below. They complete the series which deployed in the basin drained by the Minnesota River and were followed by a series of moraines formed by an ice lobe that was confined mostly to the Red River Basin.

\section{MORAINES OF RED RIVER BASIN}

BIGSTONE MORAINIC SYSTEM

Extent.-The name Bigstone is given by the writer to a prominent and somewhat complex morainic system whose southernmost part is in Big Stone and Swift Counties, Minn., and runs along the southwest side of Big Stone Lake in South Dakota. Its eastern limb runs northward from a point near Holloway, in Swift County, past Hancock, Cyrus, and Kensington, and becomes merged near Kensington with the combined Altamont and Gary morainic systems, formed on the northeast side of the Minnesota-Iowa ice. (See pls. 2 and 3.) The Bigstone morainic belt probably forms the western part of that combined morainic system northward from Kensington in western Douglas, northeastern Grant, and southwestern Otter Tail Counties, but there is no clear line of separation from the outlying morainic system.

Directly east of Dalton, in southern Otter Tail County, a narrow strip of outwash gravel sets in which extends northwestward to the Otter Tail River above Fergus Falls and thence northward past Elizabeth and Pelican Rapids to Cormorant Lake, in southwestern Becker County. The morainic belt west of this outwash plain seems to be mainly the equivalent of the Bigstone morainic belt, but later moraines become merged with it near the Grant and Otter Tail county line. The morainic belt west of the outwash plain in the vicinity of Fergus Falls thus embraces 
more than the Bigstone morainic belt. The Bigstone belt may be represented in the strong moraine that lies east of the railroad from Fergus Falls northward to Elizabeth, but from Elizabeth northward it is combined with later ones. It is probably with this morainic belt that the great outwash plain that runs from Pelican Rapids past Pelican Lake to Detroit Lakes should be correlated.

For a few miles north from Detroit Lakes there seems to be no distinct line of separation between this morainic belt and the great morainic system outside. But in northern Becker County there is a gravel plain which seems to be related to the morainic belt under discussion. It is nearly continuous northward to the Great Northern Railway at Ebro and eastward along the railroad past Bagley. The morainic belt runs northward from Bagley to Leonard, turns eastward, and follows the north side of a great outwash plain about to the north end of Cass Lake, a distance of 40 miles. The district to the east, having scarcely any roads, is difficult of access, and the data at hand are not sufficient to indicate its further course.

The width of the morainic belt whose course has just been outlined is generally not less than 2 miles and probably averages at least 3 miles. It seems thus to mark a prolonged stand of the ice border, and this interpretation is sustained by the extensive outwash plains along its outer margin.

The western or Dakota limb of this morainic belt borders the southwest side of Big Stone Lake for nearly its entire length of 30 miles and fills the space of about 5 miles between the lake and the valley of Whetstone Creek. It then extends northward to the Little Minnesota River and borders its southwest side about to Sisseton, S. Dak. An inner member follows the northeast side of the river from the south end of Lake Traverse to the place where the outer member passes to the north side near Sisseton. The combined belt then extends northward just west of New Effiington into North Dakota.

The morainic belt turns westward along the south side of the Minneapolis, St. Paul \& Sault Ste. Marie and Great Northern Railways near Hankinson, N. Dak., and lies along and south of these railroads as far as Rutland. It then takes a northward course to the Sheyenne River. Its outer part is crossed by the river near Lisbon, and the inner part near the bend a few miles below. The morainic belt then lies along the east side of the Sheyenne Valley as far north as the writer's studies extended-that is, to Valley City-and it is reported to continue much farther. The part of this morainic belt that lies within the Tower quadrangle is described by Willard ${ }^{11}$ as the

\footnotetext{
11 Willard, D. E., U. S. Geol. Surrey Geol. Atlas, Jamestown-Tower folio (No. 168), pp. 3-4, 1909 .
}

Alta Ridge and is also discussed under the name Fergus Falls moraine. 'This correlation with the moraine at Fergus Falls, Minn., seems to be sustained by the present writer's studies, but as noted above there is much complexity at Fergus Falls.

An inner member of the Bigstone morainic belt separates from the main belt near Sisseton, S. Dak., and follows the north side of the Little Minnesota River to the south end of Lake Traverse. It there crosses into Minnesota, just north of Browns Valley, and a few miles farther east turns south, passes Beardsley on the east, and comes to the middle part of Big Stone Lake about 10 miles south of Beardsley. The width of this moraine is 2 or 3 miles in much of the course above outlined and reaches 4 miles in the vicinity of Beardsley. The moraine thus approaches the main belt in breadth, and its topographic expression is nearly as strong. The greater part of this inner member and a considerable section of the main belt are shown on the Peever and Beardsley topographic maps. (See pl. 5, fig. 11.)

A rather ill-defined inner moraine, nearly 2 miles wide, runs northward from Ortonville for about 12 miles and turns eastward but dies out in a nearly level tract within 5 or 6 miles. At the south end it connects with the main belt, but at the northeast end it is several miles away. The intervening strip, however, is somewhat more undulating than the ordinary till plain, and it includes many lake basins.

There is some complexity in the part of the morainic belt in North Dakota, in which an inner member parts from and then reunites with the main belt after a distinct course for a few miles. But this part l:as been less carefully traced than the parts in South Dakota and Minnesota.

Topographic features.-The Bigstone morainic belt has a generally strong expression, though somewhat milder on the whole than the outlying combined Altamont and Gary morainic systems on its northeast border. The topography of the western limb is well shown on the topographic maps of the Beardsley, Peever, Wyndmere, and Tower quadrangles, and that of the eastern limb on the maps of the Morris, Barrett, Ashby, Wendell, Fergus Falls, and Pelican Rapids quadrangles. On the Pelican Rapids map its topography may be compared with that of the outlying morainic system. A part of the Fergus Falls quad. rangle east of Pelican River is also in the outlying stronger morainic system and much of the Ashby quadrangle is in it. It will be seen from the maps that few of the knolls in the Bigstone morainic belt in these quadrangles are more than 50 feet high, whereas in the outlying combined morainic systems many of them are 100 feet or more. In both belts basins and small lakes abound. The Bigstone belt 
becomes less prominent where it bears away from the outlying morainic system south of Kensington, in southwestern Douglas County, as may be seen by comparing its topography in the eastern part of the Morris quadrangle with that in quadrangles farther north. It is in general moderately rolling, with only a few sharp knolls. The part in northwestern Swift and Big Stone Counties has perhaps a somewhat stronger expression than that within the Morris quadrangle, showing some knolls and short ridges with steep slopes and reaching a height of 30 feet or more. This part has an outwash plain on its outer border and its relief above that plain is usually 20 to 40 feet. It has a remarkably zigzag course at this south end, with sharp reentrants and salients. The outwash material in the reentrants is in places so fine as to suggest deposition in ponded waters, but its surface seems to slope directly away from the border of the morainic belt.

Between Sisseton and Peever, S. Dak., the moraine is bordered by a narrow outwash plain, above which it rises abruptly 20 to 60 feet. A relief of 60 feet is found near the western edge of the Peever quadrangle, in sec. 6, Easter Township, Roberts County, the highest points being more than 1,280 feet above sea level. (See pl. 5.)

The Bigstone moraine varies greatly in expression in its course across southwestern Richland County and northeastern Sargent County, N. Dak., there being in places clusters of sharp knolls rising abruptly 50 to 75 feet above border tracts that have only a gently undulating surface. These variations are well shown on the Wyndmere topographic map. Knolls in the southeast corner of the quadrangle are about 100 feet above nearly level till tracts within 2 miles to the northwest. An area of about 15 square miles in the southwestern part of the Wahpeton quadrangle is thickly set with sharp knolls 50 feet or more in height, and this prominent part of the moraine extends southward to the edge of South Dakota. Lakes are inclosed among these sharp knolls, and also small dry basins. Basins are more conspicuous than knolls in the part of the moraine directly northwest of Cayuga and Ransom, as may be seen by reference to the Wyndmere topographic map.

Where the morainic belt is crossed by the Sheyenne River, below Fort Ransom, the river is now in a trench about 200 feet deep, but there is a much shallower valley running southward from Fort Ransom that probably served as the temporary course of the river during the development of the moraine. This temporary stream is thought by Willard ${ }^{12}$ to have flowed into a glacial lake, Lake Sargent, about 20 miles south of Fort Ransom.

12 Willard, D. E., U. S. Geol. Survey Geol. Atlas, Jamestown-Tower folio (No 168), p. 7. 1009 .
In much of its course across the Tower quadrangle the moraine rises distinctly above an outwash plain that lies on its outer or western border, between it and the Sheyenne River. In the northern part, in Cuba, Alta, and Noltimier Townships, the relief is 80 to 100 feet. It is this part that is known locally as Alta Ridge. The relief on the inner or eastern slope is still greater but is spread over a wider space, as may be seen by reference to the topographic map. The general width of the morainic belt in its course across this quadrangle is about 5 miles, and of this only 1 to $1 \frac{1}{2}$ miles is on the outer or western slope.

The western limb of the Bigstone morainic belt ranges in altitude from 1,100 feet or slightly less at the south, in Big Stone County, to 1,500 feet at the north, in the Tower quadrangle. In the part south of the Sheyenne River, however, there are long stretches falling between 1,100 and 1,200 feet, both in North Dakota and in South Dakota, and a few points rise above 1,300 feet. An altitude of 1,280 feet is reached in the western part of the Peever quadrangle (pl. 5), and a similar altitude in the prominent part of the moraine near the south end of the line of the Wahpeton and Wyndmere quadrangles.

The east limb and the south end of the morainic loop rise within a few miles from about 1,100 to 1,300 feet above sea level. Then long stretches of the morainic belt stand at 1,200 to 1,400 feet. There are a few hills in southeastern Clay County that rise above 1,500 feet, and several square miles above 1,400 feet. In Becker County the crest of the moraine as far north as the Buffalo River is generally between 1,400 and 1,500 feet, but in the northern part of the county the prominent parts of the morainic belt probably reach 1,600 feet. In Mahnomen County the crest is generally not far from 1,500 feet, though parts probably fall slightly below that altitude. In its course across Clearwater County the crest is usually above 1,500 feet and a few points rise above 1,600 feet. As the moraine passes eastward across southern Beltrami County the altitude gradually declines to Cass Lake. It is only 1,325 to 1,350 feet in the vicinity of this lake and Lake Winnibigoshish, but a few miles farther north the altitude is about 1,400 feet. In Itasca County, as indicated in the discussion of the moraines of red drift (pp. 55-56), the topographic expression seems more dependent on the red drift than on the overlying thin veneer of gray drift.

Character of the drift.- The amount of assorted material associated with the till in this morainic belt is less than is commonly found in belts of such promirience. There are only a few gravelly knolls, and few wells strike gravel until they get below the base of the knolls, or even into the pre-Wisconsin drift. The till is usually clayey and is calcareous nearly to the surface. It contains a remarkable amount of lime- 
stone, much of which came from formations in southern Manitoba. The oxidized part is of a rather pale grayish-brown color, so that the term "gray drift" seems more pertinent than on much of the outlying part of the Wisconsin drift that is so designated. In places the upper 4 to 6 feet has a paler color than the deeper parts, a feature that suggests a later deposition, but as this is a rather local phase it is probably due to some difference in the constitution of the drift, rather than to a marked difference in age. The paler part may in some places be merely the englacial drift deposited on the moraine as the ice border was melting back across it. It veneers knolls that are made up in the main of drift with a more pronounced brown color.

The Cretaceous shales are also a conspicuous constituent of the drift around the whole circuit of the moraine as here described. They underlie a considerable part of the morainic belt in the Dakotas and no doubt are also in large measure the cause of the very clayey character of much of the drift in Minnesota.

Boulders are very unevenly distributed over the surface but are usually not so numerous as to be a serious hindrance to the cultivation of the land. They are very largely of granite. Few of them exceed 3 feet in diameter, and the great majority are only 1 to 2 feet. Well records and road cuts indicate that boulders are not very numerous in the till. The statement made by Willard in the Jamestown-Tower folio that only 10 wells out of 200 encountered much stony material in the drift would probably apply more widely and perhaps generally. The larger stones in the till include many of limestone as well as of granite, but limestone is rare on the surface.

Outwash and border drainage.-With the exception of about 5 miles near Holloway, in western Swift County, Minn., there is a continuous plain of sandy gravel on the border of the Bigstone morainic belt from the south end of Big Stone Lake eastward along the north side of the Minnesota Valley past the Pomme de Terre River, and then northward between the moraine and the Chippewa River nearly to Cyrus. The plain extends back in the reentrants in the moraine to a distance of 6 to 8 miles from the Minnesota River, and the space it occupies on the borders of the Chippewa is still wider near Benson. The sandy land extends 5 or 6 miles east from Benson on the border of the East Branch of the Chippewa River, but it is doubtful if this tract is to be included in the outwash from the Bigstone morainic belt. This outwash is mainly fine sand with only a small number of pebbles. In places along the Minnesota River there is gravel of medium coarseness, but even there sand predominates over gravel. The Chippewa does not have a continuous belt of sandy land clear through to the Minnesota, but flows in a narrow valley with till in both bluffs for several miles along and near the line of Swift and Chippewa Counties.

On the west side of the lobe there is a narrow strip of outwash near Peever, S. Dak. It stands about 1,220 feet above sea level at the north end but falls below 1,200 feet within half a mile from the border of the moraine. It drops down below the 1,200-foot contour, and a swampy channel follows the moraine southward past Peever. (See pl. 5.) A narrow line of border drainage continues south to Whetstone Creek and down its valley to the Minnesota River at the south end of Big Stone Lake.

The writer has not examined the district outside the moraine from Sisseton northward into North Dakota, and topographic maps of that district are not yet made. The east edge of the Coteau des Prairies is near by on the west about to the North Dakota line, and the Coteau rises several hundred feet above the district traversed by the moraine. There may, how: ever, have been southward drainage from the bend of the Sheyenne River near Fort Ransom along the border of the ice to the border drainage line near Sisseton. Upham ${ }^{13}$ advanced the view that the Sheyenne entered a glacial lake in Sargent County, which he termed Lake Sargent and which he thought might at first have drained southwestward to the James River Valley and later southeastward along the east base of the Coteau des Prairies. He assumed that it stood slightly above 1,300 feet when flowing to the James River Valley but had a somewhat lower altitude when diverted to the Minnesota. The descriptions indicate that the interpretation was not based upon field observations of sufficient detail to locate an outlet to the James River.

On the areal-geology map of the Tower quadrangle in the Jamestown-Tower folio outwash sand and gravel are represented as conspicuous along the Sheyenne Valley for about 15 miles south from the northwest corner of the quadrangle and as preserved in patches farther south. The width is fully 5 miles in the northwestern part of the quadrangle and the deposits lie almost entirely on the east side of the river. On the west side the Pierre shale carries a very thin coating.

On the eastern or. Minnesota side the outwash is inconspicuous and the border drainage imperfect or interrupted from a point near Cyrus northward nearly to Fergus Falls. Narrow channels with more or less associated sand and gravel connect Jolly Ann Lake with Long and Stalker Lakes, in the northeastern part of the Ashby quadrangle, and these continue in the

12 Upham, Warren, The glacial Lake Agassiz; U. S. Geol. Survey Mon. 25, pp. 148-150, 1896 . 
southwestern part of the Underwood quadrangle to the Otter Tail River at the north end of Wall Lake. There is here a gravel deposit not examined by the writer that Upham ${ }^{14}$ described as a peculiar form of osar (esker) :

This osar is a ridge a third of a mile long, 30 to 35 feet high in its northern half, and 15 to 20 feet high in its southern half. At its south end, where it abuts on the higher area of rolling till, the gravel contains boulders up to 2 or even 3 or 4 feet in diameter, but they are absent or very rare in its other portions. The sides of this deposit have the very steep slope characteristic of osars, but it has for the most part a level, plateau-like top, several rods wide, unlike typical osars.

More or less gravelly drift with nearly flat surface extends along the Otter Tail Valley for several miles above the place where the outlet of Wall Lake enters and continues to the Pelican Valley near Elizabeth. There is also some outwash in the low strip traversed by the Pelican Rapids branch of the Great Northern Railway between Fergus Falls and Elizabeth.

There is but little gravelly drift or outwash along the Pelican River between Elizabeth and Pelican Rapids, though this was probably a line of border drainage. Its absence is perhaps due to the lack of free escape to the south for the border drainage. Some deposits of pebbleless clay occur in the vicinity of Pelican Rapids and suggest a ponding or slack drainage along that part of the ice border.

From Pelican Rapids northward past Pelican Lake to Cormorant Lake and thence northeastward past Detroit Lakes there is a belt of gravelly drift, 2 to 4 miles in width, which seems to have been laid down as outwash from the morainic belt under discussion, but parts of the surface have a surprising amount of undulation, especially in the vicinity of Detroit Lakes. This gravelly material is generally free from boulders and thus seems to lack evidence of having been laid down beneath the ice. The character of the material is like ordinary outwash, and the deposit borders the boulder-strewn moraine on the west after the fashion of an outwash apron. There is also a considerable part that has a flat surface similar to the ordinary outwash plain. The writer has not yet been able to find a fully satisfactory explanation for the rolling surface dispiayed by part of the deposit.

Only a small part of the strip of outwash that borders the moraine from northern Becker County northward to Bagley was examined, but information as to its presence and general width was obtained from persons who have traversed the region and given some attention to the character of the land. Most of it is undeveloped brushy land rather difficult of access. The part seen by the writer, along and near the Great Northern Railway, is not filled uniformly with ouc-

14 Upham, Warren, Geology of Minnesota, vol. 2, p. 550, 1888. wash. There are depressions, 20 feet or more below the plain, which are as a rule poorly drained and in places boggy. The same condition continues for a few miles northeastward from Bagley, the Clearwater River being in a swampy depression next to the moraine, east of which is a narrow strip of gravel plain. The features seem to indicate that the border drainage in this region was not free and open.

From the vicinity of Leonard, where the morainic belt turns eastward, there is a broad belt of outwash, with only small areas of till included within its general limits, extending past Bemidji Lake, Cass Lake, and Lake Winnibigoshish to Ballclub Lake. From a point near Bemidji eastward this belt is traversed by the Mississippi River, and that stream follows the north edge of the gravel plain from Cass Lake eastward. The presence of these large lake lasins in the plain seems referable to the persistence of blocks of stagnant ice during the building up of the plain by glacial drainage among them. Perhaps the general ice sheet did not melt away from Cass and Winnibigoshish Lakes until this plain had been built. The material varies greatly in coarseness, parts of it being very sandy and other parts liberally supplied with cobbles and finer stones. The sandy outwash seems to terminate at Ballclub Lake, and the Mississippi traverses a till tract from that lake nearly to Grand Rapids. This limit of the sandy outwash is probably due to a divergence of the course of the river from that of the ice border. Although no definite moraine was found north of Ballclub Lake, it is probable that the ice border extended across that area and past Jessie Lake. A sandy outwash plain covering several square miles east and south of Jessie Lake was probably formed by waters issuing from an ice border on the west and north sides of the plain. Strips of sandy gravel occur farther east in Itasca County, but they do not line up in such a way as to show connection with a single position of the ice border. It seems more likely that they were formed at various positions of the ice border in the course of its recession at places favorable for the escape of the water. This district is complicated by the presence of moraines of red drift that antedate the deposition of the veneer of gray drift of the ice invasion under discussion.

The inner member of the Bigstone morainic belt in southwestern Traverse County and northwestern Big Stone County, Minn., is bordered in the vicinity of Beardsley and southward from that place to Big Stone Lake by a plain of sandy outwash gravel. It does not extend west from Beardsley quite to the outlet of glacial Lake Agassiz, there being a narrow strip of till next to the outlet, a little higher than the plain of sandy gravel, as may be seen by reference to the Peever and Beardsley topographic maps. The out- 
wash plain is nearly 1,100 feet above sea level at Beardsley but drops below 1,090 feet about a mile to the southwest. A few small knolls 10 to 20 feet high stand in the outwash plain in the southwestern part of the Beardsley quadrangle.

Inner-border features.-The southern part of the district covered by the ice at the time it was forming the Bigstone morainic belt is a till plain in which basins are conspicuous features. Some of these line up in such a way as to indicate that they may be along the course of interglacial drainage lines that have been filled to irregular amounts by the Wisconsin drift. Artichoke Lake is the longest, reaching about 5 miles, but most of them are 1 to 2 miles long. The present drainage lines, the Chippewa and Pomme de Terre Rivers, Mud Creek, and the southward flowing part of the Mustinka River, seem to be along or nearly in line with interglacial valleys that were only partly filled with Wisconsin drift. The effect of the wind and waves on the small lakes has been to widen their middle parts and fill in the ends, so that they now have a rounder shape than at first. Between these partly filled interglacial valleys the surface of the till is in general nearly smooth, but along the valleys it is in places almost as irregular as a characteristic morainic belt. It is not likely, however, that these valley strips are to any great degree in line with the course of the ice border, and they should not be mapped as moraines.

The topographic maps of the Herman, Barrett, Chokio, and Morris quadrangles show the position of many former lakes which are now so filled as to be mapped as marshes. Some of the lakes have been drained by deep ditches, and their beds are now under cultivation to a slight extent. The Chokio topographic map shops a multitude of small wet areas which contain water only in the wet seasons. The depressions in which some of them lie seem to be getting more definite rather than to be filling up, for when filled with water the winds create waves that carry material from the deeper parts to the borders, and thus tend to develop a basin with definite rim, where at first there had been a barely perceptible depression.

Sardeson ${ }^{15}$ has indicated the probable position of successive ice borders in the recession across the area covered by the four quadrangles mentioned above. Of these the first ("ice border $A$ ") is along the inner or west edge of the Bigstone morainic belt. He describes this ice border as follows:

As the margin of the ice melted back from the terminal moraine water began to flow between it and the moraine, and thus the course of Chippewa River was again established. From the beginning the drainage line consisted rather of a chain of lakes along the ice front than of a stream valley. Into this border-drainage belt streams from the melting ice

16 Sardeson, F. W., U. S. Geol. Survey Geol. Atlas, Herman-Morris folio (No. 210), p. 7, fig. 10, 1919. brought gravel and sand, which was deposited along it. These glacial outwash deposits are not continuous but lie in patches evidently formed in succession along the valley. Those patches that lie wholly on the east side of Chippewa River are in general older than those that are crossed by it; those which lie on the west side are, with one exception, still younger. The patch at Sylvan Lake is evidently the first one formed, and its highest or eastern part is oldest. The other patches in succession down the valley were evidently deposited in like manner, and the patch near Swan Lake Church, in the Morris quadrangle, is evidently the youngest.

As the retreat of the ice border uncovered the basins in front of it so that the stream could finally take the lowest course between them, Chippewa River formed its present valley. It flows in part over glacial outwash, in part between the outwash and the till surface, and in part over till. The effect of the ice front on the course of the stream appears from the circumstance that no very great obstruction would be necessary in several places to divert the stream from its present course. Obstruction by an ice wall on the west side of the valley must, in fact, account for the turning of the stream into Peterson Lake instead of through Sylvan Lake to Barrett Lake, or, again, for its not flowing through Elk Lake to the Pomme de Terre. In the valley east of Hoffman only the sweep of the border drainage prevented the entire obstruction of the valley, which would later have turned the river's course into and through Elk Lake.

Sardeson also noted that the Pomme de Terre Valley is a partly filled interglacial valley which was occupied by glacial drainage as the ice border withdrew from it. He points out that the method of abandonment was somewhat different from that outlined for the Chippewa Valley:

During its melting the ice withdrew first from the Chippewa Valley and later from the Pomme de Terre Valley. The general direction of marginal retreat was at first from east to west, so that the trend of the ice margin was from north to south. Later, when the end of the lobe had melted back near this area, the ice front retreated more rapidly along the south border of the area than along the north border, so that the trend of the margin shifted to a point west of south. ${ }^{*} * *$ As the valley extends from north to south and as the trend of the ice margin had diverged toward the west, the valley was freed from ice gradually from south to north, so that each part in turn received drainage and outwash from the margin of the ice. The bottom of the valley is therefore occupied hy gravel and sand nearly continuously from south to north.

The trend of the ice margin in successive positions is shown by certain features of the deposit. Parallel ridges on gentle slopes show where the margin stood while each ridge was formed. In sections $26,27,34$, and 35, Darnen Township, near the south side of the Morris quadrangle, such ridges trend N. $30^{\circ}$ E., and similar ridges as far north as Pomme de Terre Lakes show the same trend. Southeast of Barrett seven parallel marginal positions, shown by ridges and slopes of the outwash, trend $\mathrm{S} .20^{\circ} \mathrm{W}$., or in the same direction as the river flows at the railway bridge. North of Barrett Lake the trend of the ice margin appears to have been nearly due north.

The drainage from the melting ice did not flood the whole valley, but the glacial river followed a narrow course, in places less than 500 feet wide, along the line of the present stream. Part of this course coincides with the trend of the ice margin at the back of the outwash, as near the south side of the Morris qualrangle; part lies between the front of the 
outwash and the east side of the valley, as near Morris; and part lies across the outwash and through lakes and the basins of former lakes now occupied by marshes and meadows. Some of the original course of the glacial stream was later abandoned. An old course that was occupied by at least part of the glacial river runs 4 miles southward from the southwest end of Perkins Lake and joins the present river's course. It is obstructed now by an ice rampart at the lake shore, and some such obstruction probably caused the diversion of the glacial stream to the course which the river now follows.

The four ice margins outlined by Sardeson are to some extent diagrammatic and are not generally marked by definite morainic features. They merely serve to show the general outline of the ice margin at successive positions in the course of its retreat across the area discussed. It is not unlikely, however, that the position " $\mathrm{B}$ " was held by the ice at about the time the inner member of the Bigstone morainic belt was being formed near Beardsley and north of Ortonville. Position "C" may perhaps be correlated with one of the two slender morainic ridges that lie just outside the basin of glacial Lake Agassiz in the northeastern part of the Beardsley quadrangle and are traceable nearly to Graceville, about 10 miles from the west border of the Chokio quadrangle. There are, however, slender moraines in the northwestern part of the Barrett quadrangle and northeastern part of the Herman quadrangle which may be correlative with those of the Beardsley quadrangle as shown more fully below (p. 112), but complete tracing across the interval of about 30 miles does not seem feasible. The fact that they have a similar position, just outside the limits of the Lake Agassiz Basin and at corresponding heights above the highest shore, is thought to favor the correlation. From the Barrett and Herman quadrangles northward these morainic ridges lie close against the inner border of the Bigstone morainic belt or are separated from it only by border drainage channels, as indicated below.

On the west side of the lobe, in Traverse County, Minn., and the northeastern part of South Dakota, a narrow till plain lies between the Bigstone morainic belt and later moraines. It falls in the Beardsley, Peever, and New Effington quadrangles. (See pl. 5.) The topographic maps with 10 -foot contour intervals clearly set forth the degree of slope. and undulation, compared with the features of the bordering moraines.

In North Dakota, from the south line to the Sheyenne River, the later moraines are separated from the Bigstone belt by only narrow strips of till plain in part of the course and are merged with it in other parts. From the Sheyenne River northward across the Tower quadrangle there is a variety of features immediately east of the Bigstone belt, or Alta Ridge, as it is there termed by Willard. Several eskers with lengths ranging from a mile or two to several miles run nearly parallel with the morainic belt, from north to south. There are also scattered kames rising 15 to 40 feet rather steeply above the bordering till plain. The eskers in places are associated with strips of rather knolly till which are only a quarter to half a mile in width. The eskers are narrow, sharp, winding ridges of the ordinary esker type, 15 to 25 feet high. The material in them is largely sandy gravel, but in places they contain gravel suitable for highway use. The kames also are valuable sources for road material. ${ }^{16}$ These appear to have been grouped by Willard, in part at least, with minor morainal deposits shown on the areal-geology map of the Tower quadrangle in the Jamestown-Tower folio. The trend of the eskers, parallel with the moraines instead of directed toward them, is unusual, and their association with knolly strips of till with the same trend seems to call for some exceptional conditions in their development, but what these conditions were is not apparent.

\section{MORAINES BETWEEN BIGSTONE MORAINIC SYSTEM AND GIACIAL IAKE AGASSIZ}

Distribution.-In the course of the recession of the ice border from the Bigstone morainic system to the south end of the basin covered by glacial Lake Agassiz one or more relatively weak moraines were developed, which fade out without completing the loop at the south end of the lobe. (See pls. 2 and 3.) On the east side they die out in the northern part of the Herman and Barrett quadrangles. On the west they are traceable about to the south end of the lobe at the east border of the Beardsley quadrangle. The writer's studies on the west side extended no farther north than the Tower quadrangle.

In the Tower quadrangle a morainic belt 2 or 3 miles wide runs southward past Buffalo and Alice, its border being 1 to 2 miles east of the Maple River. It crosses this stream near Enderlin and continues southward to the Sheyenne Valley near the south line of T. $134 \mathrm{~N}$. and range line of Rs. 54 and $55 \mathrm{~W}$., where the river turns from an eastward to a northward course.

South of the Sheyenne River two weak moraines set in whose combined bulk is scarcely as great as that of the single morainic belt to the north. The outer of these moraines passes through Milnor and, continuing southeast, is crossed by the Wild Rice River 3 or 4 miles below Ransom, in secs. 20 and 29, Herman Township, Sargent County. It enters Richland County from the southeast corner of this township, passes between Sand Lake and Silver Lake, and comes to the Bigstone moraine about 3 miles west of Lidgerwood, N. Dak. It is banked against that moraine as far east as Hankinson, a distance of 15 miles. It doubles

${ }^{16}$ Hard, H. A., A system of eskers and kames in eastern Barnes County, N. Dak. : North Dakota Agr. Coll. Survey Sixth Bienn. Rept., pp. $39-42,1913$. 
around the end of a spur of the Bigstone morainic belt at this village and within a short distance to the south becomes distinct again. Its course is southward from Hankinson to the line of North and South Dakota, and its knolls and ridges are distinctly shown in the northern part of the New Effington quadrangle (pl. 5), in eastern Elma Township and western Greendale Township, along the east side of a big slough that served as a line of border drainage. The moraine continues in a southeasterly course along the east side of the stream that drains the big slough to a minor early outlet of glacial Lake Agassiz, and crosses this outlet just west of Rosholt, S. Dak. Its course is thence southward to the middle part of Lake Traverse. It splits into two members before reaching the lake, and these appear across the lake in Traverse County, Minn., the outer in eastern Windsor Township, and the inner near the line of Walls and Lake Valley Townships, some 5 miles to the northeast. The outer member takes a curving course east and south through southwestern Walls Township and eastern Parnell Township and dies out in sec. 31, Tara Township. The inner member runs southeastward across Walls Township and the southwest corner of Croke Township into western Tara Township, where it also dies out in a till plain.

In the Sheyenne Valley in Ransom County, N. Dak., an inner morainic strip runs southeastward across Sydna Township to the Sargent County line. It is very weak, as if water-laid, in Hall Township and northeastern Herman Township, but after crossing into Richland County it is well defined in its course across Dexter Township to the north side of Swan Lake, in Moran Township. It then becomes faint in expression but seems to continue along the north side of a swampy channel that runs eastward from Swan Lake and connects with the big slough south of HanJinson, noted above. South of Hankinson it seems to be combined with the outer member, whose course has been outlined. It may find a continuation in the inner of the two morainic ridges in Traverse County, Minn. As indicated below, this inner moraine in Ransom and Sargent Counties, where weak and water-laid, seems to mark the position of the ice border at the time a narrow glacial lake formed the Milnor beach, to which Upham ${ }^{17}$ called attention. The big slough that served as a border drainage channel for the ice seems to have been the outlet of the glacial lake.

The moraines that lie between the Bigstone morainic belt and the shore of Lake Agassiz on the east side of the ice lobe are traceable no farther south in Minnesota than the northern part of the Herman and Barrett quadrangles. At the north they become merged

\footnotetext{
${ }^{17}$ Upham, Warren, The glacial Lake Agassiz: U. S. Geol. Survey
} Mon. 25, pp. 211-212, 223, 311-312, 1896. with the Bigstone belt, two of them near the line of Grant and Otter Tail Counties and a third near Carlisle, in western Otter Tail County. These distinct parts are entirely within the limits of quadrangles that are covered by topographic maps with 10-foot contour interval, on which the range in the altitudes, relief, and general topographic expression are clearly depicted.

The easternmost of these moraines follows the west side of the Pomme de Terre Valley northward from Barrett to Tenmile Lake, in southern Otter Tail County, and has a definite outwash plain on its border. Farther north the limits may lie along a chain of lakes near the borders of the Ashby and Wendell quadrangles-Mineral, Swan, Chautaqua, and Pebble Lakes-and thence along the Great Northern Railway into Fergus Falls. There are slight deposits of gravel along this line which may be outwash from the ice border. Northward from Tenmile Lake this moraine is combined with another on the west, and the combined belt fills much of the strip between this chain of lakes and the Mustinka Valley. It embraces the moraine on the west side of Fergus Falls as far out as the southward turn of the Otter Tail River. Northwest from Fergus Falls its western limits are near the Pelican River and the chain of lakes south and west of Carlisle. The western of these two moraines is traceable southward past Elbow Lake about to Cormorant Lake but is rather vague and ill defined beyond Elbow Lake. The topographic maps show that the roughness of these moraines gradually becomes less to the south, until they reach the smoothness of the bordering till plains. The ice border probably held its position along the definite parts of the moraines while making considerable recession over the district to the south near the end of the ice lobe.

A weak moraine borders the west side of the Mustinka River from the bend in southern Delaware Township, Grant County, northward to the source of the stream, about 5 miles southwest of Fergus Falls, and then along the west side of the southward-flowing Otter Tail River to the mouth of the Pelican River. It continues in a northwest course along the west side of the Pelican River to the vicinity of Lake Oscar, west of Carlisle, beyond which it is combined with the moraines east of it. Glacial drainage features, with scattered deposits of outwash gravel, are found all along the course just outlined, immediately east of the moraine. The Otter Tail and Pelican Rivers at this time found southward discharge through the Mustinka, there being a distinct channel from the Otter Tail to the head of the present Mustinka in sec. 29, Buse Township, Otter Tail County. The course of the ice border beyond the bend of the Mustinka may have been southward as far as Moose Island, 
as there is a narrow strip of sandy gravel along that line which is probably outwash from the ice border. From there the border probably turned southwestward inito Traverse County, with limits little if any outside the extreme border of Lake Agassiz. A small area of sandy gravel of outwash type is found on the borders of Eldorado and Everglade Townships, Stevens County, about 8 miles west of Donnelly, which may be referable to this ice border. Bouldery strips just south of Collis also probably fall in its course and mark the south end of the ice lobe.

From Otter Tail County northward these moraines probably form the western part of the great morainic belt that runs across eastern Clay, northwestern Becker, eastern Mahnomen, and southeastern Polk Counties into Clearwater County. A later morainic belt there comes in from the west and is more or less merged with this and earlier morainic belts thence eastward past Red Lake.

South of the Otter Tail River there is a weak moraine west of the one that fronts on the Mustinka Valley. It lies west of Upper Lightning Lake and is traceable southward about to Hereford. The Herman beach of Lake Agassiz lies along its inner or western slope. Its course and topography are shown on the Wendell topographic map.

The continuation of the ice border southward from Hereford is within the limits of Lake Agassiz. Certain features indicate that it ran along or near the course of the Norcross Beach past Norcross to Dumont and there turned northwestward past Wheaton and a prominent tract northwest of Wheaton to the State line, and thence past White Rock, S. Dak., into North Dakota. The district immediately east and south of this line has a general coating of fine sand and silt over the till, but to the west and north there is so little sand and silt that boulders on the till surface are scarcely concealed. The appearance suggests that the ice was covering the district inside this line while silt and fine sand were being laid down in shallow water outside the ice border. There is also near Norcross a slight ridging of the till, with relief of about 10 feet on the west and perhaps half as much on the east. Boulders are not conspicuous on the till west of this line in Grant County but are very numerous along nearly its entire course in Traverse County and for some distance northwestward into North Dakota. Some of these boulders may have been dropped from masses of lake ice around the head of the outlet of Lake Agassiz, but it seems probable that a considerable part, if not the major part, were deposited directly from the ice sheet. The distance to which they extend both east and west from the head of the outlet, as set forth on plates 2 and 5 , is such as to call for direct deposition from the ice sheet, for it seems unlikely that the drifting of lake ice toward the outlet would have affected a strip 15 to 20 miles each side of the head of the outlet.

The ice border in North Dakota probably extended northwestward across southwestern Lamars, northeastern Greenfield, and central Waldo Townsh.p; Richland County, to the Wild Rice River at the bend 5 miles north of Hankinson. Here as on the Minnesota side there is a sandy deposit outside the line and till at the surface inside of it along much of the way to the Wild Rice River. The border may have followed up this river to the vicinity of Wyndmere, beyond which it is lost in a belt of sand dunes.

Topographic features.-The district traversed by these moraines is largely covered by topographic maps from latitude $47^{\circ}$ southward on the Dakota side, and from latitude $46^{\circ} 45^{\prime}$ southward on the Minnesota side. 'These maps serve to show the range in altitude and the variations in topographic expression. On the Dakota side the highest part barely rises above the 1,200-foot contour for a few miles in the vicinity of Buffalo, N. Dak., and much of the district through which the moraines pass lies between 1,100 and 1,160 feet. The morainic knolls and ridges are rarely over 40 feet high and more commonly 20 feet or less. There are numerous small sharp knolls, covering but a few acres each, and larger swells with gentle slope. The map of the Tower quadrangle in the JamestownTower folio brings out the northwesterly trend of the constituent ridges, diagonally across the course of the moraine, which runs nearly north and south.

The Wyndmere topographic map shows the relatively sharp contours of the outer moraine in northeastern Sargent County, knolls 20 to 40 feet high being numerous. The inner moraine has scattered knolls on a gently undulating strip in Dexter Township, Richland County, but elsewhere has very faint expression. The highest knolls catch the 1,120-foot contour, but much of the surface is below 1,100 feet. The narrow lake outside this moraine stood at about 1,100 feet.

In its course across the New Effington and White Rock quadrangles (pl. 5) the inner moraine exhibits definite morainic features, and knolls 20 to 30 feet high are not rare. Strips of knolly land wind and interlock and stand out in spurs, as may be seen by reference to the contour maps. The part in Traverse County, Minn., has a gentle swell and sag topography, in which the swells are usually 20 feet or less in height.

The altitude on the east side of the district covered by this ice lobe is greater than in corresponding latitudes on the west side. The moraine that follows the west side of the Pomme cle Terre River from Barrett northward has points 1,250 feet above sea level in the vicinity of Barrett. Its altitude is generally between 
1,200 feet and 1,300 feet in its course through the Barrett, Ashby, Wendell, and Fergus Falls quadrangles. The moraines that lie west of this one are slightly lower, but the innermost one, in Western Township, Otter Tail_County, and Lawrence Township, Grant County, is only about 1,100 feet above sea level. The morainic expression on the east side is stronger than on the west side from latitude $46^{\circ}$ northward but is similar to or weaker than on the west side south of this latitude. Knolls and short ridges rise abruptly to heights of 50 feet or more in many places in the Ashby, Wendell, and Fergus Falls quadrangles. Basins and small lakes are also more numerous than on the west side, though not uncommon there. An examination of the topographic maps will serve to make these points clear.

In the part of western Minnesota not covered by topographic maps the moraines have about as strong expression as in the Ashby, Wendell, and Fergus Falls quadrangles. An altitude of about 1,400 feet is reached in southeastern Clay County, and the morainic belt falls largely between 1,300 and 1,400 feet in much of its course across Clay, Becker, Mahnomen, Polk, Clearwater, and Beltrami Counties. It has a strong expression as far east as the vicinity of Northome, in southwestern Koochiching County, and its highest part there is more than 1,400 feet above sea level. A strong morainic belt lying between the two parts of Red Lake may fall in this series, but it lies more nearly in the line of a later moraine, as indicated below (p. 116).

Character of the drift.-The drift in this moraine is almost entirely a clayey calcareous till. both in the Dakotas and in western Minnesota, but a liberal amount of the Cretaceous shale of the region is incorporated in it. The limestones of southern Manitoba are also well represented in both large and small blocks. There are many pebbles that show a remarkable smoothness that seems to be the effect of polishing by clay, a feature that is found in the Keewatin drift of earlier stages as well as of the Wisconsin.

There are a few kames or gravelly knolls in this belt, but not so many as in the stronger morainic belts outside. Gravel and sand beds are also interbedded with the till deposits, so that wells of moderate depth penetrate them and obtain water. In some localities these beds seem to be at the base of the Wisconsin drift, as there is a harder till reported to underlie them. The Wisconsin drift appears to be only 25 to 50 feet in depth. The older drifts thus embrace the greater part of the deposit. Rock is seldom struck at less than 100 feet, and in places the drift has been penetrated 300 feet or more without reaching rock. It is probable that granite directly underlies the drift in much of the Minnesota part, but Creta- ceous formations are present in Traverse County and throughout the Dakota part.

Boulders are not so numerous as on some of the strongrer moraines, yet they are sufficiently abundant to supply residents with foundation stones for buildings and other masonry. They are mainly granite, and most of them are less than 2 feet in diameter.

Outwash and border drainage.-Narrow channels run from lake to lake along the chain of lakes that lies just outside the outer moraine of the series under discussion and seem likely to have been developed by the border drainage. The Otter Tail River seems also to have discharged past this chain of lakes at that ijme, along or near the line of the Great Northern Railway from Fergus Falls to Pebble Lake. It flowed at an altitude just above 1,200 feet. The channel from Pebble Lake to Chautauqua Lake is at about 1,220 feet. Only a modern beach separates Chautauqua Lake from Swan Lake. A definite channel at about 1,200 feet leads from Swan Lake to the Pomme de Terre River at its bend in sec. 5, T. 131 N., R. 42 W. The course of the drainage was then down the Pomme de Terre to the Minnesota.

When the moraine that lies west of the Mustinka was being developed the Otter Tail River and border drainage from the country as far north as the chain of lakes west of Carlisle passed into the Mustinka at its head, at an altitude about 1,120 feet, a bench mark in the midst of the valley near the present divide being at 1,122 feet. The southward descent along this valley is very gentle, being only 20 feet in 15 miles, to the south border of the Wendell quadrangle. Slight deposits of outwash or sandy gravel occur in the valley at a few places, but it is mainly a mucky bed. The same is true in the part above the bend in the Herman quadrangle. There are outwash deposits farther south which stand a little higher than those along the Mustinka and which may have been deposited during the recession of the ice border to the position along the west side of the Mustinka Valley. They lie east of Moose Island and extend north for 6 miles in a strip nearly half a mile wide. Their altitude is 1,100 to 1,110 feet; those along the Mustinka a few miles north stand at slightly less than 1,100 feet.

The border drainage connected with a later weak moraine in Western Township, Otter Tail County, and Lawrence Township, Grant County, is above the 1,080 -foot contour in much of its course south from the Otter Tail River and so is nearly at the level of the highest shore of glacial Lake Agassiz. The border of the ice at that time probably passed into the Lake Agassiz Basin near Hereford. By that time Lake Agassiz was occupying the extreme south end of its basin and its waters may have extended along the ice border as far north as Hereford. This moraine is 
distinct from earlier ones only from the Otter Tail River southward. It is probable that the Otter Tail took a southward course along the line of border drainage just described while this moraine was being made. As soon as the ice border had melted back a mile or so from the moraine the Lake Agassiz waters probably extended to the present river in the southern part of Orwell Township (T. 132 N., R. 44 W.), Otter Tail County.

On the west side of the ice lobe the border drainage in the Tower quadrangle appears to have followed the course of the Maple River southward as far as Enderlin, N. Dak., and then to have taken a southwestward course to the Sheyenne River, as indicated on maps in the Jamestown-Tower folio. At the time the later of the two moraines was formed in the district south of the Sheyenne River there was border drainage through Lake Milnor and its outlet clear to the Minnesota Valley. But so definite a line of escape when the earlier moraine was being formed has not yet been recognized. Perhaps waters were ponded in the Maple River drainage basin at that time to a sufficient height to find discharge through the Bigstone morainic belt, and thence into the Minnesota Valley. The present writer's studies in that region have been too slight to warrant more than this suggestion.

A channel or drainage course in northwestern Big Stone County, Minn., that heads near the outer moraine, about 3 miles northeast of Barry, and runs westward past that village to Fish Creek and thence to Big Stone Lake probably carried the drainage from the south end of the ice lobe. Erosion features set in directly west of Barry. At and east of Barry there was some deposition of sandy material. Its features are well shown on the Beardsley topographic map. (See pl. 5.) The head of the channel is 1,100 feet above sea level, but there are places nearer the moraine that are slightly below that altitude and probably were occupied by ponded waters. The width of the channel is less than a quarter of a mile in much of its course. It is thus small compared with the outlet of Lake Agassiz but is about as large as the one along the Mustinka River, described above.

There are small lines of drainage outside the moraine in the New Effington quadrangle (pl. 5) where the streams seem to have been short-lived. One of these branches off from Big Slough just south of the line between North and South Dakota, runs past New Effington and comes to Cottonwood Slough near the south side of the quadrangle. The present divide in it is a mile north of New Effington and is below the 1,090 -foot contour. The descent is very slight to the south, for the channel remains above the 1,080-foot contour for 5 miles and probably entered Cottonwood Slough at nearly 1,080 feet, the outflow from Lake
Agassiz having cut the slough down at least 50 feet in that vicinity. There is a slight northward descent from the divide to the junction with Big Slough, but the channel seems to have been occupied for its entire length by a southward flowing stream. The general width of this channel, as shown on the New Effington map, is fully a quarter of a mile, but its depth is only about 10 feet.

Between Cottonwood Slough and the south end of the channel just noted is a smaller one that branches off from the west bluff of Cottonwood Slough in sec. 8, Harmon 'Township, and comes back to it near the line of secs. 24 and 25, Hart Township, Roberts County, S. Dak. It is just below the 1,080 -foot contour and serves to show that when the Lake Agassiz outlet began work in cutting this channel the bed was nearly 1,080 feet above sea level, and it was cut down to a little below 1,030 feet at the time the Lake Agassiz waters ceased flowing through it. The course of this short-lived channel is shown on the New Effington map.

\section{ERSKINE MORAINE AND ITS PROBABLE CONTINUATIONS}

Extent.-The moraine to which the writer applies the name Erskine is well defined in the vicinity of Erskine, Polk County, Minn., outside the limits of Lake Agassiz but obscure where deposited in the lake. (See pls. 1 and 3.) Erskine stands near the place where the morainic belt makes an abrupt turn from an eastward course to a north-south course and where it is exceptionally prominent. The part in Polk County was examined both by Upham ${ }^{18}$ and by Todd, ${ }^{19}$ but neither of them gave it the course beyond this county that it seems to the present writer to have. The part south from Erskine is described first, and then the jrobable continuation toward the east.

The moraine runs southwestward nearly to Fertile and is spread over a width of 5 or 6 miles, its inner border being at Maple Lake and its outer border near Gossen. The moraine turns to a course slightly east of south before reaching Fertile and crosses the northeastern part of Norman County, keeping just outside the highest beach of Lake Agassiz. This part is well defined and has a width of 2 or 3 miles. Farther south it is very feebly developed for 5 or 6 miles in the vicinity of the Wild Rice River, perhaps because of local ponding there, as shown by a silt deposit over the till on each side of the river. The moraine again becomes well defined in the southern part of T. 144 N., R. 43 W., and runs southward past Flom into the northwest township of Becker County. It there swings westward and crosses the Northern Pacific

18 Upham, Warren, Geology of Minnesota, vol. 4, p. 133, 1899 ; U. S. Geol. Survey Mon. 25, pl. 17, 1896.

19 Todd, J. E., Geology of Minnesota, vol. 4, pp. 104-108, 142-143, fig. 9 , pls. $62,64,1899$. 
Railway 2 or 3 miles south of Ulen. It comes to the shore of Lake Agassiz directly west of Hitterdal, in the southern part of T. 141 N., R. 45 W. The course from that point southward is just inside the limits of the glacial lake. It is marked by a steep rise from a lower tract on the west, but does not have similar relief on the east. There are places a few miles north of Barnesville where it comes up to the level of the highest beach and carries that beach on its crest. From the vicinity of Barnesville it bears west of south as a faint and barely visible swell into northern Wilkin County. From Deerhorn Creek, in the central part of T. 136 N., R. 46 W., it bears southwestward to the Red River Valley a few miles north of Wahpeton, N. Dak. It continues southward on the west side of the Red River as a bouldery strip about to Wahpeton and then swings westward at what appears to be the terminus of the ice lobe.

There is very little to show the position of the ice border in this water-laid portion but is probably passed near Mooreton, N. Dak., and followed up the east side of Antelope Creek to the edge of a higher plain, which Upham ${ }^{20}$ termed the Sheyenne delta, and thence along its base northwestward from Walcott across the Sheyenne River into southern Cass County, N. Dak. It seems likely to have been merged with earlier moraines from Alice northward, where it was deposited on the land outside the limits of Lake Agassiz. The higher plain to which Upham gave the name Sheyenne delta is discussed in connection with the features of Lake Agassiz (pp. 126-127). The abrupt border which it presents in northern Richland County and southern Cass County may be due in large part to the presence of the ice sheet there while it was being built up.

East of Erskine, Minn., the moraine is well defined as far as the line of Polk and Clearwater Counties and lies immediately outside the highest beach of Lake Agassiz. Thence to the southwest border of Red Lake no definite morainic ridge is present. The altitude is rather low for several miles on each side of the Clearwater Valley, and probably the ice here terminated in ponded waters. Well-defined morainic features set in at the eastern edge of Clearwater County and border the south side of Lower Red Lake closely as far east as Redby. East of Redby there is some uncertainty as to how much should be correlated with the Erskine moraine. Strong morainic features appear in a belt several miles wide running southeastward past Nebish and Blackduck, but this morainic belt may be older than the Erskine. It seems on the whole quite as probable that the ice border made a swing around the east end of the Lower Red Lake Basin and had a reentrant between Upper and Lower

${ }^{20}$ Upham, Warren, U. S. Geol. Survey Mon. 25, pp. 189, 315-317, pl. $28,1896$.
Red Lakes, there being a strong morainic belt between these lakes that may be interlobate. On this interpretation the ice border finds its continuation eastward on the north side of the Battle River. For a few miles it stands below the highest beach of Lake Agassiz, but it rises above the lake level about 3 miles northwest of Kelliher. Thence it runs eastward past Gemmel. Morainic features are well defined for several miles both east and west from Gemmel, but they fade out near the ninety-fourth meridian. Some 15 to 20 miles farther east, in the vicinity of Effie, morainic features again become definite and continue eastward across the Bigfork River and along the north side of the Deer River past Deer Lake. In this district, however, the red drift has morainic expression, and there is some uncertainty as to the extent to which the morainic features are due to the gray drift. The altitude also is higher in the belt running eastward from Effie than in the one at Gemmel. It is not improbable, therefore, that the ice border eastward from the ninetyfourth meridian had a position farther north than the moraine that runs east from Effie. Perhaps it kept on the north side of Caldwell Creek as far as the bend in T. 65 N., R. $26 \mathrm{~W}$, and thence passed northward toward Littlefork village. It is scarcely feasible in so sparsely settled and heavily wooded a district to trace ill-defined marginal belts, and the above statements are merely suggestions as to possible continuations.

Topographic features. - In the part outside the limits of Lake Agassiz and of places where local ponding seems to have occurred, the moraine ordinarily consists of small sharp hummocks, from 10 feet or less to 25 feet or more in height. A few knolls reach heights of 50 to 60 feet. In the water-laid part the surface is nearly free from hummocks, and only a smooth ridge of very gentle slopes is to be found. In places the ridge is lacking, but a strip of boulders marks the course of the ice border. In the district east of the ninety-fourth meridian the gray drift generally masks the red-drift topography, and its own features are difficult to make out.

Character of the drift.-Along much of its course in Polk County and northeastern Norman County, Minn., the Erskine moraine contains considerable sand and gravel. In some places a thin veneer of gray till covers a nearly pebbleless sand. It is the sand rather than the overlying till that gives the hummocky topography. Some of it looks like dune sand and suggests the view that at a time of ice recession prior to the advance to the position marked by the moraine the sand had been drifted into dunes, perhaps from the border of a temporary local lake held between the ice and the higher land outside.

In the moraine along the south side of Lower Red Lake and also in that between Upper and Lower Red Lakes considerable sand and gravel are interbedded 
with the till. The sand and gravel are thus abundant throughout most of the well-defined part of the morainic belt.

In the water-laid part there is generally a clayey till with very little associated sand and gravel. In places a thin cover of sand has resulted from subsequent lake deposition. Such deposits have usually a thickness of only a few inches and rarely over 5 feet. Upham ${ }^{21}$ has, however, mapped parts of this moraine with such a sand cover as thick delta deposits in Lake Agassiz, a conspicuous example being the "Buffalo delta," near Muskoda. On the area thus mapped the sand is scarcely 5 feet thick and in places is too thin to cover the boulders of the underlying moraine. The "Sand Hill delta," near Fertile, also has very little true delta material. 'There is, however, enough sand to supply material for small dunes. These features are more fully treated in the discussion of the beaches of Lake Agassiz (pp. 126-127).

\section{HOLT MORAINE}

The moraine to which the writer applies the name Holt, from a village in Marshall County that stands on it, lies within the limits of the glacial Lake Agassiz and thus was deposited in ponded water. Under this condition it would scarcely be expected to have much topographic prominence. (See pls. 1 and 3.) Yet its course is not difficult to trace for 100 miles or more, from Lake of the Woods County west and south to southern Polk County. It forms a belt several miles in width and thus seems to mark a long stand of the ice border. The moraine forms the border of an ice lobe that apparently projected southward in the basin of the Red River at least to northern Norman County. A bouldery strip there is thought to mark the terminus of the ice lobe.

At its northeast end this moraine becomes a definite feature in the southeastern part of T. 159 N., R. 33 W., about 20 miles south of the Lake of the Woods. To the east there is a lower tract drained by the Rapid River. It is probable that the ice at this time doubled around the east end of the moraine and extended southward perhaps to Upper Red Lake. The-moraine between Upper and Lower Red Lakes may have been formed at this time. There is also a strip with here and there a morainic aspect that leads from Upper Red Lake eastward to the Bigfork Valley just below, Big Falls, Koochiching County, and is represented to the northeast by ridges at Wisner and Happyland and a more conspicuous strip from Nakoda to International Falls. If this correlation with the Holt moraine proves correct, the ice lobe had a decided protrusion into the Rainy River Basin as well as that of

\footnotetext{
${ }^{21}$ Upham, Warren, U. S. Geol. Survey Mon. 25, pp. 290-292, 1896.
}

the Red River, for, as determined by Johnston, ${ }^{22}$ the border of the calcareous till bears northwestward from International Falls. The features from Upper Red Lake to International Falls constitute a less definite or less continuous ridging than the Holt moraine but are the only ones found that seem at all likely to be correlative with it.

The Holt moraine seems to underlie a series of beaches of Lake Agassiz in T. 159 N., Rs. 33, 34, 35, 36 , and $37 \mathrm{~W}$., and T. 158 N., Rs. 38,39 , and $40 \mathrm{~W}$. The gravelly beach ridges and associated sand dunes are the conspicuous features of the surface, but the high altitude of this area seems due to the presence of a morainic ridge. One of the shore lines, in secs. 22 , 23 , and 24 , T. 159 N., R. 35 W., is thickly set with boulders, at an altitude of 1,270 to 1,280 feet, and it is probable that till immediately underlies the beach there. The highest beach in that area is about 1,290 feet above sea level and the highest dunes are slightly above 1,300 feet.

Near Thief Lake, in northeastern Marshall County, till comes to the surface and the moraine swings around from a westward to a southward ccurse. The moraine parallels the Thief River on the west from Thief Lake to the junction of this stream with the Red Lake River at Thief River Falls and thence holds a similar relation to the Red Lake River southward nearly to Red Lake Falls. There it is crossed by the Red Lake River as the stream turns westward. South of the river it continues in a course slightly west of south, with some prominence above the district west of it, past Benoit and Melvin about to the Sandhill River, where it ceases to have topographic distinctness. The course of the border of the ice lobe farther south and west seems to be along a bouldery strip that runs westward across northwestern Norman County to the Red River, as noted by Upham. ${ }^{23}$ The present writer, however, does not follow Upham in referring the bouldery strip to the Fergus Falls moraine or the "Leaf Hills moraine." It seems referable to a much later time than those moraines.

It is probable that the ice border on the west side of the lobe at the time the Holt moraine was formed had about the position shown by Upham ${ }^{24}$ along the east side of the Goose River and the east edge of what he termed "Elk River delta" northward to Pembina Mountain and thence along the base of that escarpment into Manitoba.

The altitude of this morainic belt ranges from slightly less than 1,300 feet in Lake of the Woods County to about 900 feet in the axis of the Red River

22 Johnston, W. A., Rainy River district, Ontarlo: Canada Geol. Survey Mem. 82, 123 pp., map, 1915.

${ }^{2}$ Upham, Warren, U. S. Geol. Survey Mon. 25, pp. 165-166, pl. 19, 1896.

${ }^{24}$ Idem, pl. 19. 
Basin. It drops below 1,200 feet near Thief Lake and is below 1,100 feet from Red Lake Falls southward. At the Sandhill River it is less than 1,000 feet. The morainic strips to the east of the Red Lakes are usually within 10 or 20 feet above or below the 1,200foot contour. The surface of Upper Red Lake is 1,175 feet above sea level, and it is a very shallow body of water. There is thus very little range in the interval between Upper Red Lake and International Falls.

The most conspicuous drainage effects produced by this moraine are the control of the Thief and Red Lake Rivers in their southward courses on its outer border, on the east side of the ice lobe, and the southeastward course of the Goose River in North Dakota, on the west side of the lobe. Yet the relief above the plains traversed by these streams is only 10 to 20 feet, and part of this is due to the lake deposits that cover considerable parts of the morainic belt.

Where the moraine is not coated with lake deposits it is as a rule thickly strewn with boulders, notably from Red Lake Falls southward. The boulders are mainly of granite, derived in all probability from the country east of the Lake of the Woods. The till is thickly set with limestone pebbles, not only in the part southwest of Beltrami County but also in that to the east, clear to International Falls.

The thickness of the drift appears to be very great from Lake of the Woods County southwestward, in places over 400 feet. But from the Bigfork River to International Falls the rock comes to the surface at short intervals. The drift, however, may have considerable thickness at intervening points.

The following record of a test boring made by the city of Thief River Falls serves to illustrate the great thickness and the variability of the drift in this part of Minnesota :

\section{Record of boring at Thief River Falls}

[Altitude 1,133 feet]

Sand

Blue clay

Till, rather hard

Muddy sand and clay

Till, rather hard

Quicksand

Till, rather hard

Quicksand

'Till, rather hard.

Quicksand

Till, rather hard

Quicksand

Till, rather hard.

Granite at 462 feet; altitude of rock surface, 671 feet.

In the bluffs of the Red Lake River near Red Lake Falls there is considerable nearly pebbleless blue gummy clay that covers the more stony till to a depth ranging from 5 to 15 feet or more. It was formed before the lake sand and gravel were spread out over the surface and thus seems likely to have had some connection with the melting ice sheet. The fact that the ice border terminated in water of considerable depth in this district may account for the very gummy, clayey character of the deposit, but the writer does not feel certain of the interpretation. The deposit seems to be of very small extent. The till is generally more stony and shows a pebbly concentrate where washed by the waves between the shore lines.

This moraine is probably the catchment area for a flowing-well district on its north slope south of Lake of the Woods, in the vicinity of Swift, Roosevelt, and Williams. The wells are sunk to depths ranging from about 60 feet to 120 feet or more. They go largely through till and obtain water in interbedded sand and gravel.

The ridges between the Red Lakes and the Bigfork River consist mainly of sand and gravel, so far as exposed above the level of bordering swamps. But from the Bigfork Valley northeastward to International Falls the ridges consist mainly of calcareous clayey till.

\section{MINOR MORAINIC RIDGES IN KITTSON COUNTY, MINN.}

There are two till ridges in Kittson County, Minn., that seem likely to have been developed as ice-border features. (See pls. 1 and 3.) One of them sets in about 4 miles south of Bronson and runs southward for fully 10 miles, its south end being about 2 miles south of the Kittson-Marshall County line. It is about a mile in width and stands 10 to 20 feet above the plains on each side. It is liberally strewn with boulders and a clayey till comes to the surface at numerous points along its course. The plains on each side have a heavier coating of sandy lake-deposited material.

The other ridge begins near the Manitoba-Minnesota boundary about 12 miles east of the Red River and runs south-southeast for 7 or 8 miles, its southern terminus being about 2 miles southeast of Orleans, Minn. This ridge is scarcely half a mile in average width but is a distinct feature. It rises 15 to 20 feet above the border plains and its surface is thickly set with boulders. Stony till forms the body of the ridge. There is also till near the surface on the bordering plains. That on the east has more sand associated with it than that on the west. Within a short distance to the west a thicker deposit of lake clay sets in which so conceals the underlying till that it is exposed only along the valleys. This lake clay is a conspicuous deposit for 10 to 15 miles east of the Red River southward from the international boundary across Kittson, Marshall, Polk, and Norman Counties, and it has a similar extent on the west side of the river in rortheastern North Dakota. 


\section{GLACIAL LAKE AGASSIZ}

\section{EARLY OBSERVATIONS AND INTERPRETATIONS}

Evidence of the former presence of a great lake in the Ked River Basin was noted in 1823 by Keating ${ }^{25}$ and in 1848 by Owen, ${ }^{26}$ who recognized Pembina Mountain as the shore of the great lake. Its presence in Canada was noted by Palliser ${ }^{27}$ in 1857 , by Hind ${ }^{28}$ in 1858, and by Dawson ${ }^{29}$ in 1873. Dawson's report carries detailed notes made along the part of the international boundary between the Lake of the Woods and Pembina Mountain. The outlet of the ancient lake through Lake Traverse, Big Stone Lake, and the Minnesota River was first described by Warren ${ }^{30}$ in 1868. It was in commemoration of the valuable work done by Warren along the Minnesota Valley that Upham $^{31}$ named the outlet of Lake Agassiz the River Warren. That Lake Agassiz was a glacial lake held up by an ice barrier appears to have been first pointed out by Winchell ${ }^{32}$ in 1873 . The shore lines of Lake Agassiz were made the subject of several years' study by Upham. ${ }^{33}$

\section{CHARACTER AND EXTENT OF PRESENT STUDIES}

The present writer's studies of the features of Lake Agassiz extended over the entire width of the lake bed from its south end northward to latitude $47^{\circ}$ and embraced the small strips outside the Herman beach of Lake Agassiz that were occupied by short-lived lakes immediately adjacent to the ice sheet while its border was still about as far out as the limits of the hed of Lake Agassiz. The results of the studies in the Dakotas are briefly set forth in an earlier paper. ${ }^{34}$ The results of joint studies by Leverett and Sardeson in the Herman and Chokio quadrangles in Minnesota are presented by Sardeson ${ }^{35}$ in the Herman-Morris folio.

The full extent of Lake Agassiz in Minnesota and the distribution of such beaches as have been mapped are set forth on the maps of the surface formations of Minnesota by Leverett and Sardeson which accom-

${ }^{25}$ Keating, W. H., Narrative of an expedition to the source of St. Peters River, Lake Winnepeek, Lake of the Woods, etc., performed in the year 1823, vol. 2, p. 3, London, 1825 .

${ }_{26}$ Owen, D. D., Report of a geological survey of Wisconsin, Iowa, and Minnesota, p. 178, Philadelphia, 1852.

${ }^{27}$ Palliser, John, Journals, detailed reports, etc., presented to Parliament, 1863 , p. 41.

${ }^{28}$ Hind, H. Y., Report on the Assiniboine and Saskatchewan exploring expedition, pp. 39, 40, 167, 168, Toronto, 1859.

${ }^{9}$ Dawson, G. M., Report on the geology and resources of the region in the vicinity of the forty-ninth parallel, from the Lake of the Woods to the Rocky Mountains, p. 245, Montreal, 1875.

${ }^{30}$ Warren, G. K., Chief Eng. Ann. Rept. for 1868, pp. 307-314.

31 Upham, Warren, Am. Assoc. Adv. Sci. Proc., vol. 32, p. 231, 1884.

\$2 Winchell, N. H., Minnesota Geol. and Nat. Hist. Survey First Ann. Rept., p. 63, 1873 .

as Upham, Warren, The glacial Lake Agassiz: U. S. Geol. Survey Mon. 25, 658 pp., 1896.

34 Leverett, Frank, Early stages and outlets of Lake Agasslz: North Dakota Agr. Coll. Survey Sixth Bienn. Rept., pp. 17-28, 1913.

ss Sardeson, F. W., U. S. Geol. Survey Geol. Atlas, Follo 210, 1919. pany Bulletins 12, 13, and 14 of the Minnesota Geological Survey, revised and reproduced here as Plates 1 and 2. The mapping is necessarily incomplete in the wooded northern part of the State, but it is thought that the extent of the Lake Agassiz waters has been approximately determined. There are some areas in the unsettled northern part of Minnesota that seem to have been ponded before the ice had retreated far enough for the main body of water to have ingress to that district. This ponding seems to have reached higher levels than were reached by the main water body. But in the present poor state of accessibility it will scarcely be feasible to clear up fully the relation of these earlier lakes to the body of water to which the name Lake Agassiz is applicable.

Inasmuch as Upham gave most of his attention to the highest beach of Lake Agassiz, the lower shores are incompletely mapped in the plates accompanying his report. The present writer's work was not sufficiently detailed to map all the beaches and bars, but he has brought the series to much fuller representation in the maps here presented as Figures 15-21. Upham's studies were extended only as far east in northern Minnesota as the vicinity of the Red Lakes, so the mapping farther east and north is almost entirely the work of the present writer. A reconnaissance of several counties of northwestern Minnesota by Todd ${ }^{36}$ gave some data on shore lines that do not appear in Upham's report. It was Todd who found evidence that Upham's "Beltrami Island," north of the Red Lakes, was not an island at the highest stage of the lake but carries bars and beaches of the lake on its highest part. The mapping of these lake features was carried into some detail by the present writer. The Campbell beach was found to have a somewhat different course in northern Minnesota than Upham had represented, and it was mapped in some detail clear through to the international boundary. Its course in the district east of the Lake of the Woods in Canada was mapped at the same time by W.A. Johnston, of the Canada Geological Survey, and field conferences were held with him during the mapping on both sides of the boundary. Johnston ${ }^{37}$ later mapped the Campbell beach around an island that stood above it in southeastern Manitoba, on the west side of the Lake of the Woods. Its extent is shown on the map of the Campbell lake stage, Figure 15. This beach, as interpreted by Johnston, ${ }^{38}$ marks a return of the drainage of Lake Agassiz to its southern

${ }^{38}$ Todd, J. E., Geology of Minnesota, vol. 4, pp. 106-110, 123-126, $149-150,1899$.

${ }^{37}$ Johnston, W. A., Winnipegosis and upper Whitemouth River areas, Manitoba ; Plejstocene and Recent đeposits : Canada Geol. Survey Mem. 128 , pp. $29-31,1921$.

30hnston, W. A., The genesis of Lake Agassiz; a confirmation : Jour. Geology, vol.. 24, pp. 625-638, 1916 ; Recorda of Lake Agassiz, in southeastern Manitoba, and adjacent parts of Ontario, Canada: Geol. Soc. America Bull., vol. 28, pp. 145-148, 1917. 
outlet after the lake had been temporarily drained eastward and this temporary outlet had been closed by a readvance of the ice sheet.

\section{PONDING NORTH OF MESABI IRON RANGE PRIOR TO FORMATION OF LAKE AGASSIZ}

Evidence that ponding occurred in front of the receding ice sheet in the district north of the Mesabi range was noted by Winchell, ${ }^{39}$ who gave a series of names to what he conceived to be a group of lakes. One of these, "Lake Norwood," had an outlet through

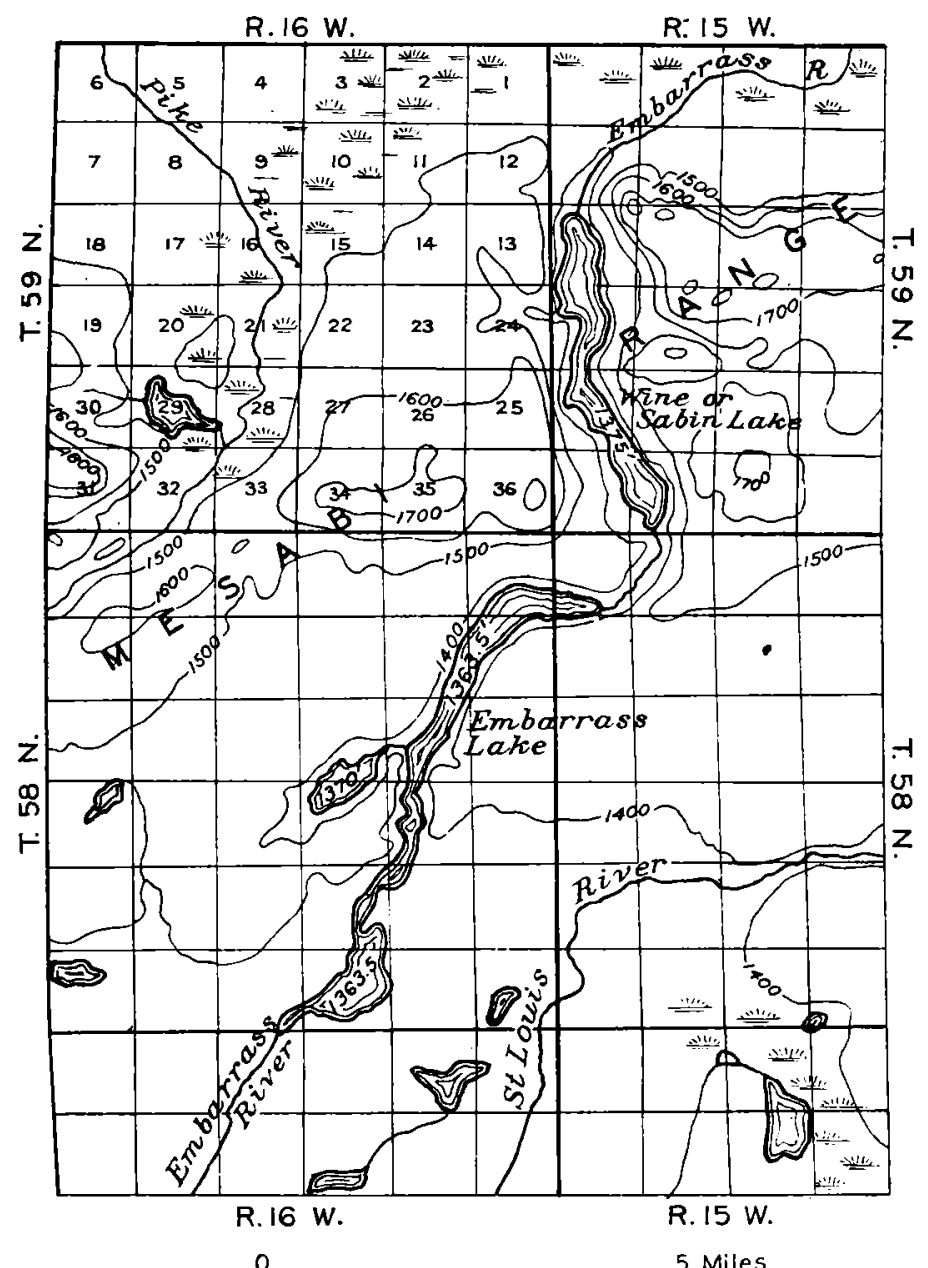

Figure 14.-Outlet of glacial Lake Norwood across Mesabi iron range

the Mesabi range where the Embarrass River now passes through it in St. Louis County. (See fig. 14.) This lake was thought to have been formed at an early stand of the border of the Patrician part of the ice sheet and to have been a small body of water, only 25 miles long from east to west, lying south of the Vermilion moraine. It was Winchell's conception that when the ice sheet receded to the north of that moraine water ponded in other places to the east found passage to "Lake Norwood" and discharged through its out-

Winchell, N. H., Glacial lakes of Minnesota : Geol. Soc. America Bull., vol. 12, pp. 125-126, 1901. let. It was not known at that time that the Keewatin part of the ice sheet caused ponding in the district occupied by these lakes after the Patrician part had receded from it. The only available outlet for the ponded waters through the Mesabi range seems to be that used by Winchell's "Lake Norwood," and the name "Lake Norwood" may be applicable to the water held by the Keewatin ice, as well as to that held by the Patrician.

The altitude of the outlet is 1,375 feet where the Embarrass River utilizes it in crossing the Mesabi range. As some northward differential uplift has occurred in the ponded district the evidence of ponding will be found up to altitudes corresponding to this uplift. East of Pelican Lake, near Orr station, a gravelly bar apparently produced by the ponded water was found at an altitude of 1,420 feet, and there is a general appearance of wave washing in that vicinity to a corresponding level. This is 60 feet higher than the highest beach that seems referable to Lake Agassiz. The outlet is a capacious one, adequate for the discharge of a large lake, being from a third to half a mile wide in the passage through the Mesabi range.

Much of the district between the Embarrass River and the southeast end of Vermilion Lake is considerably above the level of the bed of the outlet where it enters the Mesabi range. Unless the outlet was cut down to a corresponding amount during the ponding there would have been only narrow strips of water in this district. Before the ponding ceased, or before Vermilion Lake took its present northward discharge, there appears to have been a narrow outlet to the south to the Embarrass River. It followed the Pike River (reversed) to a point within 3 miles of the Embarrass River and then opened a passage to that river across secs. 30,31 , and 32 , 'T. 60 N., R. 15 W., and sec. 5, T. 59 N., R. $15 \mathrm{~W}$. At that time the water level in the Vermilion Lake district was 1,400 to 1,405 feet above sea level, as shown by a distinct shore line well displayed in the vicinity of Tower. This is 40 feet above the present level of Vermilion Lake. The surface of the peaty deposits in the channel that connects the Pike and Embarrass Rivers is slightly above 1,400 feet, but the bottom of the peat or bed of the channei is below 1,400 feet and in harmony with the broad floor of the Embarrass Valley.

Vermilion Lake has a shore line at about 1,380 feet above sea level, or 20 feet above the present level of the lake. This altitude seems a little too low for the lake to have had connection with the outlet to the Embarrass Valley. Whether it was held to this height by a barrier in the line of its present northward outlet has not been determined. Perhaps it found discharge into the Littlefork Valley, either through a swamp that leads west from the Pike River in secs. 
17 and 18, T. 61 N., R. 16 W., or through some other of the low passages that connect the Vermilion Basin with the Littlefork lowland. Winchell ${ }^{40}$ gave to this to give a passage for water from the south bend of the Sheyenne River southeastward to the head of the Millake stage the name "Onnamani," the Indian name for Vermili on, and suggested that it drained west to Pelican Lake.

LAKE MILNOR (A PREIIMINARY STAGE OF GLACIAL IAKE AGASSIZ)

The ponding of water in the Red River Basin began as soon as the recession of the ice border exposed land that drained toward this basin. There was at first only a narrow fringing water body. This became expanded as the ice border melted back from the south end of the basin into $\mathrm{Can}$ ad a. Moraines marking halting points in this recession have already been described.

Before the ice border had receded in Rans o m, Sargent, and Richland Counties, N. Dak., to a position inside the limits of Lake Agassiz it held a narrow lake on its southwest border in these counties, whose le,vel was about 20 feet above the highest or Herman beach of Lake Agassiz. The shore line formed on the landward side of the lake was recognized as such by Upham ${ }^{41}$ and named the Milnor beach, from Milnor, N. Dak., near which

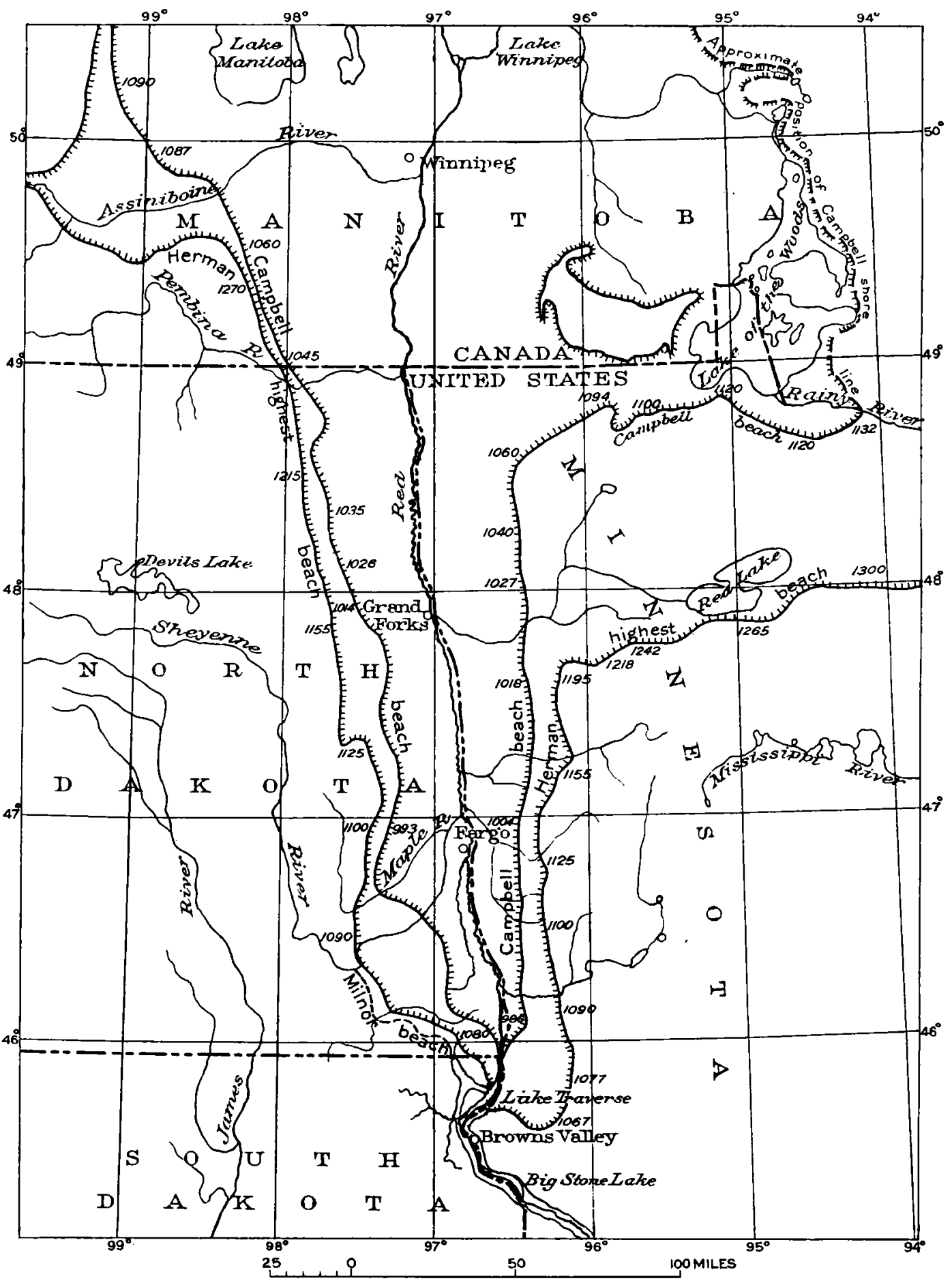

Figure 15.- Outlet and southern part of glacial Lake Agassiz basin, showing Milnor, Herman, and Campbell shore lines (hachured). (Revised by Frank Leverett from Upham's Plate XXXIV.) Partly hypothetical east of Lake of the Woods. Campbell beach of island west of this lake by W. A. Johnston. Figures show altitude in feet above sea level it passes. At the beginning of Lake Milnor the ice border seems to have been melted back only far enough

to Winchell, N. H., op. cit., p. 126.

4 Upham, Warren, U. S. Geol. Survey Mon. 25, pp. 211-212, 223, 311-312, 1896.
17.) There seems to have been a definite stand of the ice border along a line only 2 to 5 miles inside the limits of Lake Milnor, with a weak moraine marking much of its course. The moraine is a partial equivalent of one which runs southward from Buffalo, 
N. Dak., to the south bend of the Sheyenne River.42 ${ }^{42}$ tributary of the Wild Rice River in Sargent County. It is obscured by sand deposits near the Ransom-Sar- On crossing the Wild Rice River and entering Rich-

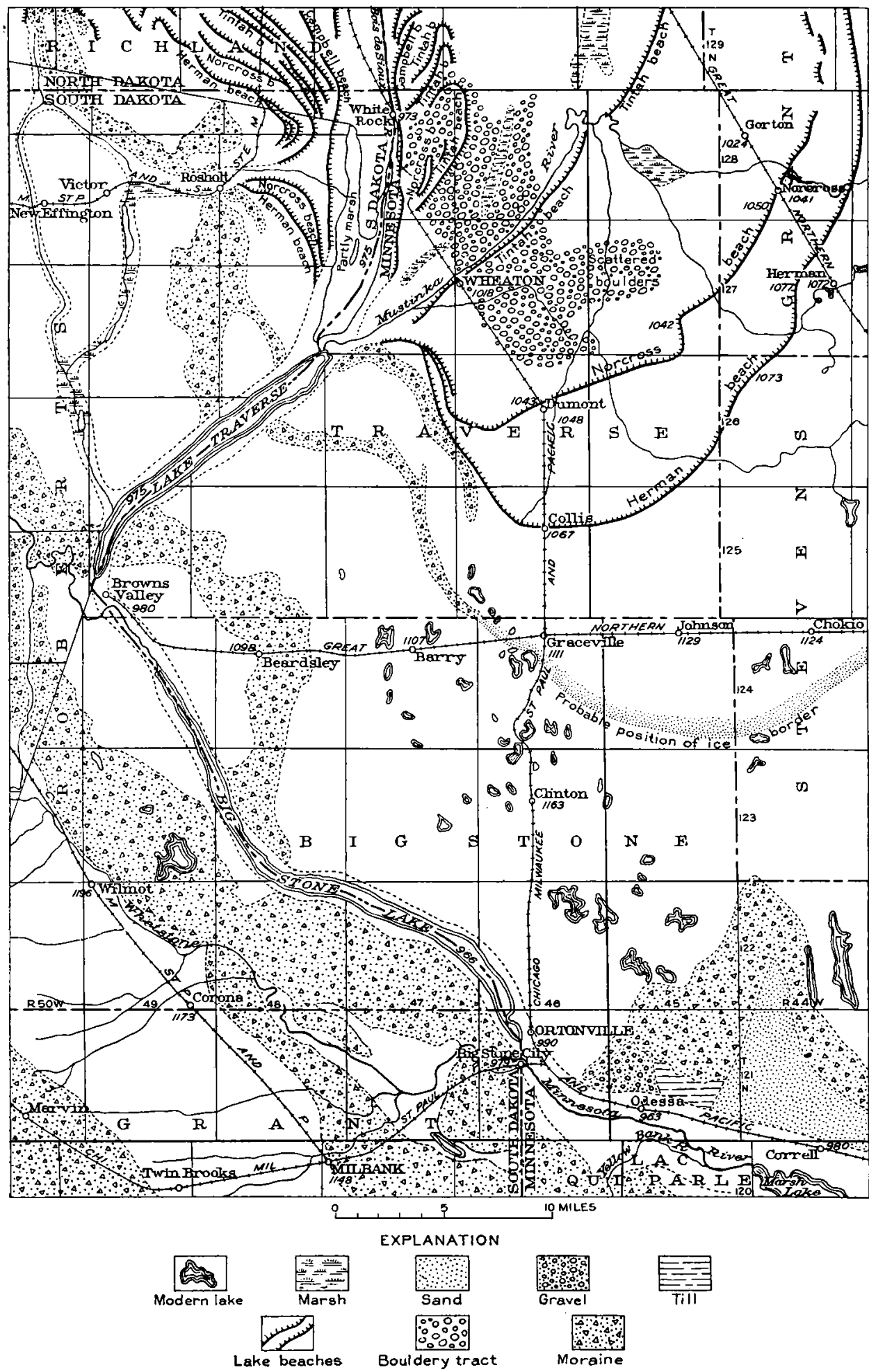

FIGdRF 16.-Map of southern part of glacial Lake Agassiz basin, showing glacial moraines, shore lines, and outlet of the glacial lake. (Revised by Frank Leverett from Upham's Plate XXIII.) Figures show altitude in feet above sea level

gent County line, and is a low, smooth ridge, probably formed in the lake on the north side of a western

42 Hall, C. M., and Willard, D. E., U. S. Geol. Survey Geol. Atlas, Casselton-Fargo folio (No. 117), 1905. land County it assumes greater strength of expression, with knolls 20 feet or more in height, and crosses T. 131 N., R. $52 \mathrm{~W}$., from the northwest to the southeast corner. It is capped by dunes northwest of Hankinson. The continuation seems to be past the village of Hankinson in a belt of knolls and short ridges that follows the east side of the Lake Milnor outlet southward into South Dakota. Its further continuation is thought to be in a moraine lying just outside the limits of Lake Agassiz in South Dakota and the neighboring part of Minnesota. The ice seems to have made a later stand along a line a short distance inside the one just noted, but this position is not marked by so definite a glacial ridging, and parts of it are obscured by sandy deposits. A very bouldery area is thought to mark the continuation of the ice margin across the northeast corner of South Dakota into Minnesota.

Lake Milnor beach.-The Lake Milnor beach has its northernmost development at the edge of the Sheyenne Valley about 8 miles north of Milnor. The river entered Lake Milnor at its extreme northwest end and was its largest extraglacial affluent. The delta deposits of this stream are conspicuous for 4 or 5 miles from the head of the lake and replace to some extent other shore features. There is, however, a conspicuous gravel bar at the line of Tps. 133 and 134 N., R. 54 W., and for a mile southward it lies east of the delta. Its most prominent points are shown by the Wyndmere topographic map to reach the 1,120-foot contour.

The beach is continuous in its course through Milnor Township (T. 132 N., R. 54 W.), from sec. 6 to sec. 30. For 3 miles southeast of Milnor it is cut in 
the inner or northeast slope of a moraine. Farther southeast, in Milnor, Hall, and Herman Townships, there are gravelly bars, formed on low ridges that stood 1 to 2 miles out in the lake. An altitude of 1,108 feet is recorded on one of these bars at the corner of secs. 4, 5, 8, and 9, Herman Township, in the Wyndmere quadrangle, but the bars are extended down below the 1,100-foot contour. From eastern Herman Township (T. 131 N., R. 53 W.) southwestward past Silver Lake to Lidgerwood and thence eastward nearly to Hankinson there seems to have been only a narrow strip of water, 1 to 2 miles wide, along the ice edge and shore features are obscure. In Hankinson and for about 4 miles to the south the lake action is well exhibited on several offshore knolls, as well as on the shore proper, at about 1,100 feet above sea level. The outlet heads 4 miles south of Hankinson and leads nearly due south into South Dakota. No clearly defined shore features were noted southeast of the head of the outlet, but there is a silt-covered plain above the level of the Herman beach of Lake Agassiz, on each side of the State line, which seems to have been submerged and coated with deposits from Lake Milnor.

Lake Milnor outlet.-The outlet is a channel about half a mile in width (fig. 15), whose course to the State line is well outlined on the soil map of Richland County. A belt of muck, with a chain of marshy ponds along it, traverses the eastern edge of T. $129 \mathrm{~N}$., R. $50 \mathrm{~W}$. Its bed is about 1,080 feet above sea level where it leaves the Wahpeton quadrangle, which is within a mile of the head of the outlet, but neighboring parts of the Milnor beach stand at 1,100 feet. The water may thus have been about 20 feet deep, or quite as probably the outlet was deepened somewhat after the beaches were formed. The bed of the outlet, as shown by the New Effington topographic map (see pl. 5), passes below the 1,070-foot contour just south of the State line and is still above 1,060 feet 6 miles to the southeast, near Victor, S. Dak., where it comes to a minor outlet of Lake Agassiz. The part of this outlet to the south was probably partly excavated by the drainage from Lake Milnor, but was deepened by the drainage from Lake Agassiz during the development of the Herman and Norcross beaches, as indicated below. This outlet opens into Lake Traverse near its south end, only 5 miles north of Browns Valley, Minn.

\section{ICE-BORDER LAKE (PRE-HERMAN BEACH STAGE) EAST OF OUTLET}

Studies in connection with the preparation of the Herman-Morris folio brought to light evidence that ponded water was present at the south end of the Red River Basin in Grant, Stevens, and Traverse Counties, Minn., 20 to 25 feet higher than the Herman beach, or about 1,090 feet above sea level. The area thus covered is slightly wave-washed and coated to some extent $67665-32-9$ with silt. No definite shore line was noted along the border, and the ponding was probably of short duration. Deposition of silt on the border of the ice sheet might have been rather rapid. No outlet for the water was noted, but it is probable that the water found escape to Lake Traverse near the point where the Herman beach opens into the outlet, a short distance southwest of Wheaton, and thence into the Minnesota Valley. It is thought that the ice border stood near a line running southward past Norcross at the time of this ponding and was also pressing against the blufflike prominence southwest of Wheaton. A slight rec'ssion from this prominence would permit the water to be drained down to the level of the Herman beach. The presence of considerably more silt on the part of the lake bed between the Herman and Norcross beaches than on the part inside the Norcross beach is thought to show that the ice held a position along or near the line of this beach while the silt was being deposited. The silt between these beaches may thus antedate the Herman beach. As indicated below, the ice border scems to have made a great recession to the north during the development of the Herman beach.

\section{RIVER WARREN, THE OUTLET OF LAKE AGASSIZ}

The discharge of Lake Agassiz past Lake Traverse and Big Stone Lake to the Minnesota Valley was first described by G. K. Warren in 1868 in connection with a survey of the Minnesota Valley. As a tribute to Warren for his important scientific work here Upham ${ }^{43}$ gave the outlet of Lake Agassiz the name River Warren. It was recognized by Warren that the size of the valley is out of proportion to the small stream (the Minnesota River) that now occupies it. He noted also that its head opens into the Red River Basin, in which evidence of the former presence of a great lake had been found by earlier explorers. This opening is near the north end of Lake Traverse, which lies within the main valley cut by the outlet waters, though it now drains northward through the Bois de Sioux River, a tributary of the Red River, the present divide being at Browns Valley, Minn.

In the early stages of the lake, during the development of the first two beaches (Herman and Norcross), the waters at the head of the outlet were divided between two channels. The main flow went through the valley in which Lake Traverse lies; a minor line of discharge opened a channel, known locally as Jim's Valley, which has a circuitous course west and south from a point near the north end of Lake Traverse at White Rock, S. Dak., past Rosholt and Victor to the south end of this lake. It is well shown under the name "Cottonwood Slough" on the topographic maps of the White Rock, New Effington, and Peever quadrangles. (See pl. 5.) This valley appears not to have been recognized by Warren or by Upham as an outlet

\footnotetext{
${ }^{4}$ Upham, Warren, Am. Assoc. Adv. Scl. Proc., vol. 32, p. 231, 1884.
} 
feature of Lake Agassiz. Its bed is 50 to 60 feet higher than the surface of Lake Traverse, being mainly between 1,020 and 1,030 feet above sea level, while Lake
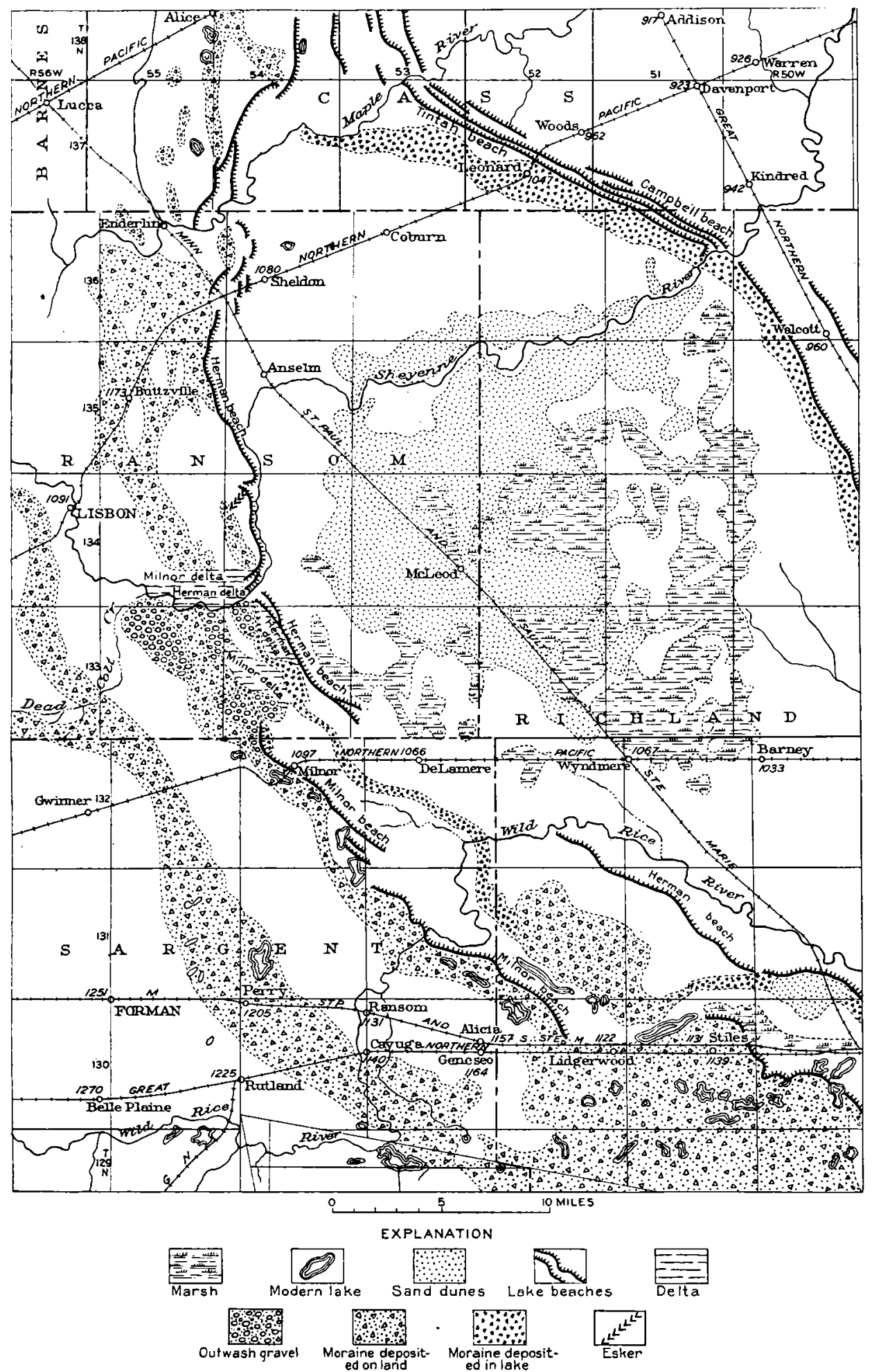

Figdre 17.-Map of shore lines, dune areas, and moraines at west side, near southern part, of glacial Lake Agassiz basin. (Revised by Frank Leverett from Upham's Plate XXVII.) Figures show altitude in feet above sea level

Traverse is 974 feet. Its channel is also only about one-fourth as large as the one in which Lake Traverse lies, being about half a mile wide, while the main channel is more than 2 miles in average width as far south as the place where they unite. For most of the 28 miles of its length it is a boggy slough, in part occupied by ponds, as indicated on the New Effington and Peever topographic maps, but at each end it is fairly well drained by small streams leading down to Lake Traverse.

This channel also served as the outlet for the waters from Lake Milnor southward from Victor, S. Dak., as indicated in the discussion of that small predecessor of Lake Agassiz. Possibly the Milnor waters also used the part of the channel east of Victor. However, only a small part of the excavation of this channel is referable to the Milnor waters, there being fully 50 feet of later deepening by the waters of Lake Agassiz.

The main outlet shows a remarkable constriction to less than a mile just below the point where this minor outlet comes to it. It there crosses a prominent morainic belt, and this is apparently the cause for the narrowness, as no rock formations have been noted in the bluffs. As shown by the contours on the Peever topographic map the brow of each bluff stands more than 1,130 feet above sea level, or more than 150 feet above the surface of Lake Traverse. At the village of Browns Valley the bluffs drop below 1,100 feet on the outer border of this moraine and the valley widens to $11 / 4$ miles. It is here that the divide between the Gulf of Mexico and Hudson Bay drainage basins is located. The valley is at present in process of filling at this place by alluvial material brought in by the Little Minnesota River, the alluvial fan being slightly more than 980 feet above sea level at the west side, where the stream enters, but a little under that altitude along the east side. There is a low shale knoll in the southeastern part of the village that rises to the 
1,010-foot contour. The part of the valley in which height of its surface, or about 800 feet above sea level. Big Stone Lake lies is also exceptionally narrow. The There was thus a fall of only about 160 feet in the 200 deep part is but little more than half a mile wide. It miles from Big Stone Lake, or less than 10 inches to is bordered by a terrace at about 1,050 feet above sea level, or 80 feet above the surface of the lake, but this is narrow and if included gives the valley a width of scarcely three-quarters of a mile. Possibly the Cretaceous shale is present in the lower part of the bluffs, but no exposures were noted by the writer. The bluffs consist largely of till, and this is probably in part of pre-Wisconsin age. It seems to be exceptionally resistant, as much so as the soft-rock formations.

Along much of its course from Big Stone Lake to Fort Snelling, where the Mississippi enters, the River Warren channel is fully 2 miles wide, in places 4 miles or more, and its usual depth more than 100 feet. It bears evidence all along its course of rapid deepening by a stream of great volume. Its deepening went on much faster than that of tributary valleys, which were being excavated by the small streams of their present drainage basins. In excavating this large valley the river uncovered granite ledges at numerous points, and they stand now as prominences in the valley bottom, with heights as great as 75 feet or more. There seems to have been very little excavation in rock above the junction with the Mississippi at Fort Snelling. But a prominent rock barrier was cut away between Fort Snelling and St. Paul. This was done by the recession of a waterfall, as interpreted by Sardeson.44
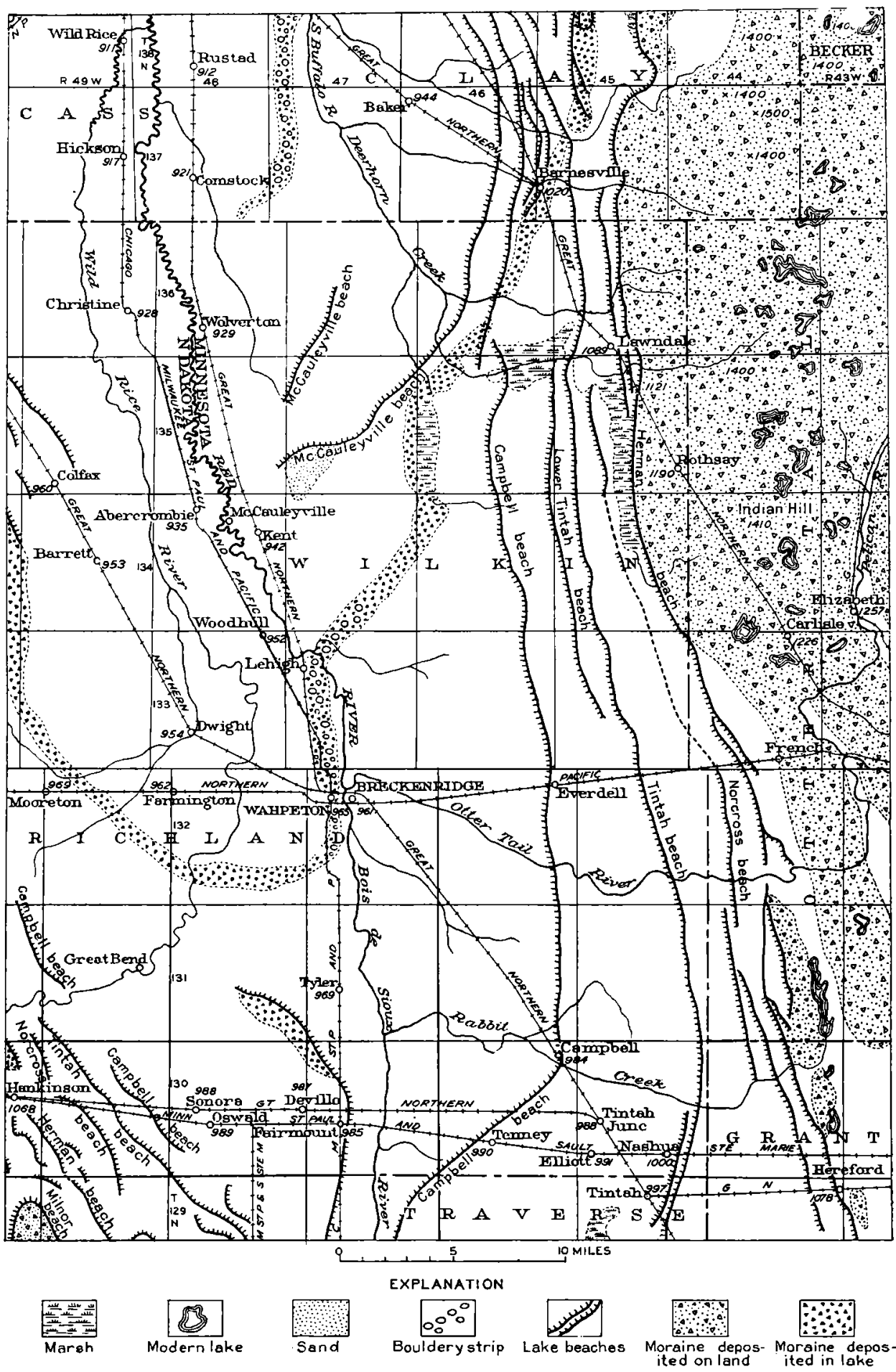

Figure 18.-Map of shore lines and moraine at east side, near southern part, of glacial Lake Agassiz basin. (Revised by Frank Lererett from Upham's Plate XXIV.) Flgures show altitude in feet above sea level
During this recession, which occupied several thousand years, the part of the valley immediately above the barrier was kept up to the

"Sardeson, F. W., U. S. Geol. Surrey Geol. Atlas, Minneapolis-St. Paul folio (No. 201), p. 11, 1916. the mile. After the removal of this rock barrier the valley was cut down about 160 feet at Fort Snelling, thus increasing the average gradient to about 18 inches to the mile. By the time the outlet was abandoned it 
had cut down to 800 feet above sea level as far up as the vicinity of New Ulm. There is a fall of about 60 feet in the 60 miles from Big Stone Lake to Granite Falls. The river then makes a descent of nearly 50 feet in about 6 miles in passing Granite Falls and Minnesota Falls, the steepest rapids in the course of the river. It is in this part that granite knobs are most prominent in the valley bottom.

Since the Lake Agassiz waters ceased flowing through this outlet the tributary streams have been bringing in more material than the present drainage down the valley is able to remove. As a consequence a ponding has been produced in the sections just above the filling. The Mississippi has in this way raised the level of the lower part of the Minnesota some 30 feet or more. This part is being rapidly filled with sediment, but small lakes along and near the stream below Shakopee mark the unfilled places. At the lower end of Lake Pepin the Chippewa River of Wisconsin has brought in the sediment that produced this ponded condition of the present Mississippi River. The water level at the lower end of Lake Pepin is now at least 50 feet above the old bed of the Lake Agassiz outlet at this point.

The effect of the large flow of water from Lake Agassiz is noticeable along the Mississippi for hundreds of miles, even to the head of the Gulf Embayment. This great stream cut away much of the filling left by the glacial drainage from the Wisconsin ice sheet and reduced the valley bottoms to a gradient of less than 6 inches to the mile. Many projecting points in the bluffs of the Mississippi were cut away, and the valley was increased in width. This is a marked feature as far down as the vicinity of Clinton, Iowa. There are places, as at Barn Bluff, in Red Wing, where the side of a hill facing the river was so much cut away as to give this face a striking contrast to the gentler slopes on other sides of the hill.

During the discharge of the Lake Agassiz waters through the southern outlet the head of the outlet was deepened about 90 feet. Of this deepening Upham ${ }^{45}$ estimated that 25 or 30 feet preceded the development of the Norcross beach, 15 feet occurred between the Norcross and Tintah beaches, and 30 feet between the upper Tintah and Campbell beaches, leaving about 15 feet below the Campbell beach.

Upham interpreted each of the beaches as representing a time of stability of level and the spaces between them as marking " rhythmic stages of elevation of the country across which the River Warren flowed" and inferred that the head of the outlet stood about 90 feet higher at the cessation of the discharge of water through this channel than at the beginning. His work on the shore lines brought to light evidence that the

45 Lpham, Warren, U. S. Geol. Survey Mon. 25, pp. 222-225, 1896. northern part of the basin suffered several times this amount of uplift and that the higher shore lines show greater uplift than the lower ones. It is thus clear that the uplift was in progress during the cutting down of the outlet. It is not so clear, however, that the uplift was rhythmic. There is a similar spacing of beaches in the southern part of the Lake Michigan Basin, where there appears to have been no uplift during their development. The materials in which the outlet was cut vary considerably in degree of resistance and may thus have given rise to variations in rate of deepening. The removal of a resistant barrier might easily be followed by a rapid lowering as great as the space between successive shore lines.

There is also some question as to the uplift being equal to the amount of deepening at the head of the outlet. A neighboring glacial lake in the James River Valley in South Dakota, to which Todd ${ }^{46}$ gave the name Lake Dakota, is thought by him to show no evidence of tilting in its shore lines. The position of its north end about opposite the south end of Lake Agassiz suggests that the tilting may have extended lut little south of the southern limits of that lake and that the outlet has had little or no uplift. This view is also sustained by the fact that there is a very slight tilting of the beaches for some distance north from the south end of the lake, as indicated below (p. 132).

\section{SO-CALLED DELTAS OF IAKE AGASSIZ}

There are some remarkably large areas of sandy land opposite places where certain streams discharged into Lake Agassiz, which have been classed by Upham as deltas. The largest is north of Pembina Mountain, where the Assiniboine River entered the lake, and is estimated to cover at least 2,000 square miles. The deposit opposite the entrance of the Sheyenne River, in southeastern North Dakota, covers about 800 square miles. The area called the Elk Valley delta, in northeastern North Dakota, embraces 300 square miles, and the Pembina area, a little farther north, about 80 square miles. There are two of the sand areas on the east shore, bordering the Buffalo and Sandhill Rivers, each covering about 15 square miles. No such sandy areas appear where several other streams entered on the east shore, such as the Otter Tail, Wild Rice, and Red Lake Rivers, yet these streams are larger than the Buffalo and Sandhill Rivers.

Such conditions, as well as the remarkable size of the sandy areas, suggest that the material was not entirely supplied by these inflowing streams. On the contrary, it appears probable that the greater part was contributed directly by the melting ice sheet as its

16 Todd, J. E., Am. Assoc. Adv. Sci. Proc., vol. 33, map opp. p. 392, 1885 ; U. S. Geol. Survey Bull. 158, p. 125, 1899. 
border was receding across them. The Sheyenne area of sand has an abrupt northeast border, like an icecontact face, rising 30 to $\tilde{5} 0$ feet above the clayey plain to the northeast. The sand on this border is but a few feet thick and covers a highly calcareous, somewhat pebbly clay, which seems best interpreted as a glacial deposit in ponded water.

The Buffalo area presents a similar steep bank on its lakeward side, and the sand is only 3 to 5 feet thick, or about one-tenth the thickness inferred by Upham. Beneath it is clayey till, with boulders on its surface which in places are but partly covered by the sand.

The Elk Valley area of sand has a moraine on part of its landward side, as indicated by Upham, and thus seems to be largely an outwash deposit from the ice border. The Assiniboine area of sand may have had a considerable part contributed by that large river, but the ice border, as indicated by Upham, appears to have been receding across it during its development.

It is a question whether the name delta should be applied to deposits of this character, in which inflowing rivers appear to hare been only minor contributors of material. Certainly the size of these areas should not be taken as an indication of the work done by inflowing streams during the life of Lake Agassiz.

\section{HERMAN SHORE IINES}

General features.-The name Herman beach was applied by Upham ${ }^{47}$ to the highest of the four shore lines of Lake Agassiz that open into the southward outlet, the name being derived from the village of Herman, Minn., which stands near it. It was thought by Upham that during the time this beach was being formed the ice border made a recession from the south end of the Red River Basin northward into Canada, and he mapped it on the west shore as far as Riding Mountain, about 100 miles north of the international boundary. In the northern part of this shore uplift was sufficient to split the beach into several distinct members, and the first or highest of these was thought by Upham to terminate south of the Assiniboine River along the base of Pembina Mountain. That being the case, the ice border had receded past the international boundary before the uplift which accompanied the melting of the ice sheet had set in. This matter, however, in the present writer's opinion, should be given more critical study than it has yet received. As interpreted by Upham this beach is split at the international boundary into seven members, the lowest of which is 55 feet lower than the highest. Of this difference 10 feet is referred to the cutting in the outlet and 45 feet to uplift. It thus appears that the uplift

${ }^{47}$ Upham, Warren, Minnesota Geol. and Nat. Hist. Surrey Elghth Ann. Rept., pp. 84-87, 1880 ; U. S. Geol. Survey Mon. 25, pp. 276381 , 1896. was well under way before the lake began the development of the Norcross beach, the next below the Herman.

It was also Upham's opinion that the ice border had receded on the east shore beyond the limits of the district he studied while the highest member of the Herman series of beaches was being formed, there being on the northern part of this shore a similar series to that noted on the west shore. Neither Upham's studies nor those of the present writer have been sufficiently thorough to make certain that the ice sheet had made so great a recession before uplift set in. It seems probable, however, that the ice border had receded into Canada on this shore before the lake began the development of the Norcross beach.

The present writer's studies extended no farther north than latitude $47^{\circ}$ on the west shore of Lake Agassiz, but they were carried to the international boundary on the east shore. From the vicinity of Maple Lake northeastward they went beyond the part that Upham surveyed. This extension was into a forested region and was of the nature of a general reconnaissance, which had for its aim the determination of the approximate limits of Lake Agassiz and the collection of such data as are available as to the altitude of the several shore lines developed in that district. The highest of the shore lines appears to have an altitude high enough to class it with the Herman series of beaches.

It was noted by Upham that the east shore shows a more rapid rise in its beaches than the west shore, and he concluded that the direction of most rapid rise is about north-northeast. The present writer's studies indicate that the tilt line for a considerable part of the district in Minnesota and North Dakota is about N. $35^{\circ}$ E. But, as shown below, it may be farther eastward in the northern part of these States. A comparison of the data on altitudes of the Herman beach in the southern part of the shore of Lake Agassiz given by Upham in Monograph 2.5 with the data that appear on the topographic maps shows that some of Upham's levels do not apply to the highest shore but are in harmony with adjacent ridges a few feet lower. The difference in places is as great as 20 feet but usually is 10 feet or less. There are also some errors as to location in Upham's data, for at the time of his survey there were long uninhabited stretches where information as to the position of section lines was difficult to obtain. It is therefore not surprising that such errors appear.

In the south end of Lake Agassiz, south of latitude $46^{\circ}$, there are some variations in altitude in what is interpreted to be the Herman beach that do not seem attributable entirely to differential uplift. Perhaps ice attraction may have had some influence here in the 
very early part of the development of the beach to points on this section of the east shore catch the 1,080 cause an exceptional height. The Herman beach on the east shore shows a rise of about 10 feet in 30 miles

foot contour. But on the west shore the beach rises above the 1,080-foot contour in the northern part of

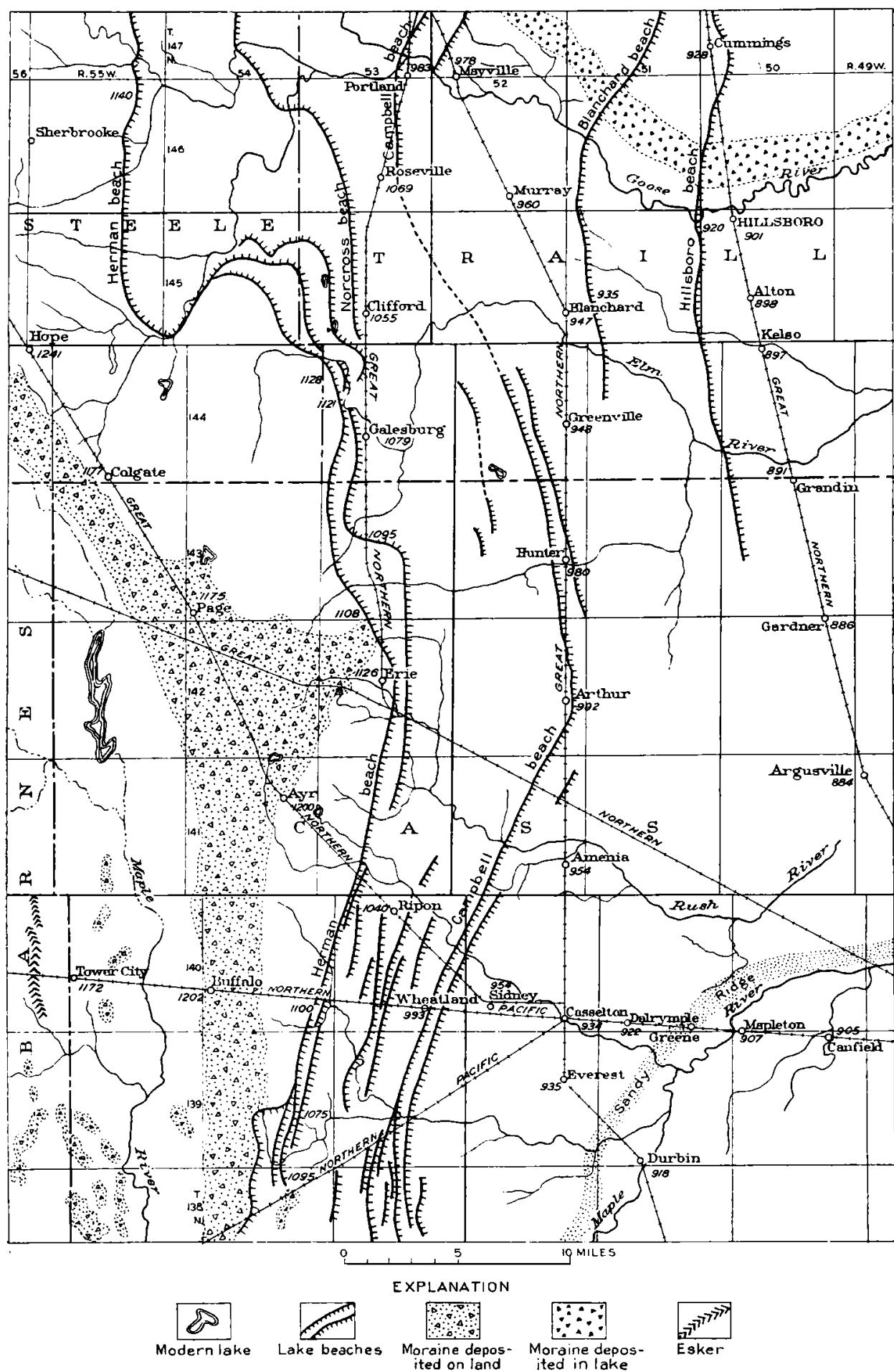

Flgure 19.-Map of moraines and western shore lines of glacial Lake Agassiz, Cass and Traill Counties, N. Dak. Revised by Frank Leverett from Upham's Plate XXVIII; shore lines north of T. $140 \mathrm{~N}$. from Upham. Figures show altitude in feet above sea level

from Collis, at the extreme south end of the lake, to the north line of the Herman quadrangle, at latitude $46^{\circ}$, or from 1,065 to 1,075 feet above sea level, and no the New Effington quadrangle, just south of latitude $46^{\circ}$, in secs. 9,15 , and 16, Greendale Township, Richland County, N. Dak. This seems to be a culminating place in that part of the western shore, for the altitude drops below 1,080 feet within a mile to the north, in the Wahpeton quadrangle, and remains below it clear to the Sheyenne Valley in the western part of the Wyndmere quadrangle, a distance of about 42 miles. Directly east of this culminating place, in secs. 10 , 14, 23, and 24, Greendale Township, there is a lower beach which barely rises above the 1,060-foot contour and is clearly correlative with the level reached by the lake near the end of the Herman beach stage, as a result of the cutting down of the outlet. Perhaps this beach forms the main shore from that locality northwestward to the Sheyenne Valley.

There is a similar condition on the east shore, in the Wendell quadrangle, which is just north of latitude $46^{\circ}$. In the south half of the quadrangle, where the beach trends northnorthwest, it rises 10 feet in 8 miles. But in the next 8 miles to the north it does not show any rise, and the trend here is nearly due north. It is thought that the part which shows the rapid rise may have been af: fected by ice attraction at a time when the ice sheet was still occupying the part of the shore farther north. If so, this inclined part is somewhat older than the level part to the north.

These variations which the topographic maps reveal are likely to be duplicated on parts of the shore farther north, wherever the ice border in receding northward 
made a stand long enough for the waters that were drawn up against it to develop a definite beach. But in the lack of topographic maps such places are not readily identified. It should also be borne in mind that in places beaches were built to exceptional heights above the ordinary lake level because of peculiar exposure to the effect of strong winds. There are also places where the beach was subject to shoving by ice on the lake to a level above its original position. It is thus not singular that there should be a difference of several feet in the height of a beach within a relatively short distance, independent of any differential uplift.

Features along the beach in the south end of the lake afford evidence that the outlet was deepened a few feet during the development of the beach. Thus there are places in the Herman quadrangle where the beach has two or more crests banked against one another. In such places the outer crest is usually a little higher than the one banked against it. West of Herman gravel was deposited on the inner slope of the beach, on ground that had been eroded while the waves were making the crest of the ridge. The features of the beach seem to warrant the conclusion that the head of the outlet was deepened to a level a little below the 1,060-foot contour during the Herman beach stage. It seems to have been about 1,065 feet above sea level at the beginning of this stage.

Features of the west shore.Both the main outlet by Lake Traverse and the minor outlet by Jim's Valley or Cottonwood Slough lead away from Lake Agassiz a few miles northwest of the south end of the lake bed, which is at Collis, Minn. (See figs. 15-18.) The part of the western shore to the southeast of the main outlet is below the 1,070-foot contour, as shown on the maps of the in feet above sea level
Beardsley and White Rock quadrangles. But the part between the two outlets, in White Rock Township, Roberts County, S. Dak., is along and slightly above the 1,070-foot contour. North of the minor outlet a

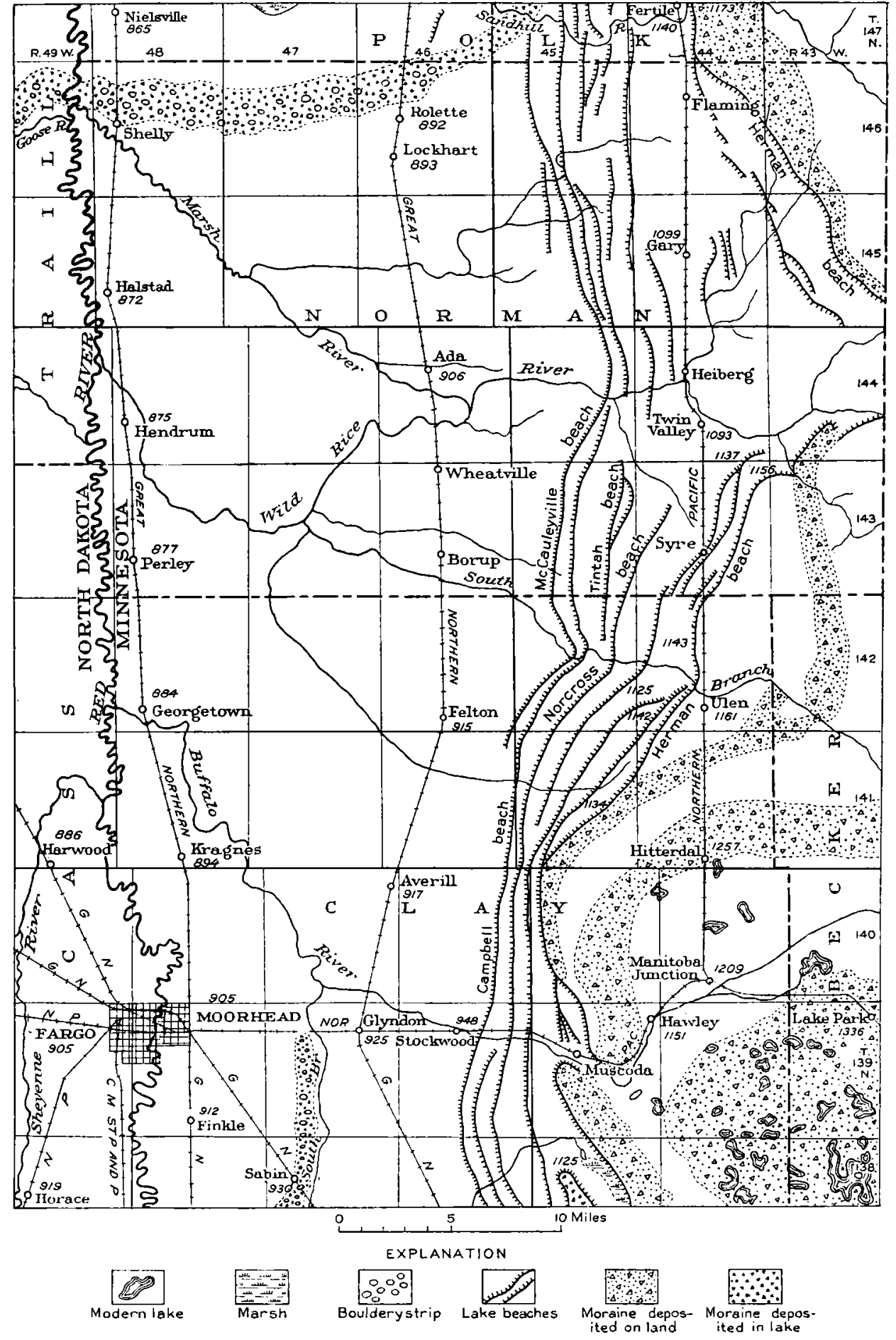

Figure 20.-Map of moraines and eastern shore lines of glaclal Lake Agassiz, Clay and Norman Countles, Minn. Revised by Frank Leverett from Upham's Plate XXV. Figures show altitude series of gravel bars of the Herman beach stage turn into the outlet, the highest of which is above 1,070 feet and the others near 1,060 feet and in places a little lower, thus showing the effect of a cutting in progress 
in the outlet. Northwestward from this outlet as far as the State line of North Dakota the main beach stands above 1,070 feet, but in southwestern Lamars and eastern Glendale Township, Richland County,

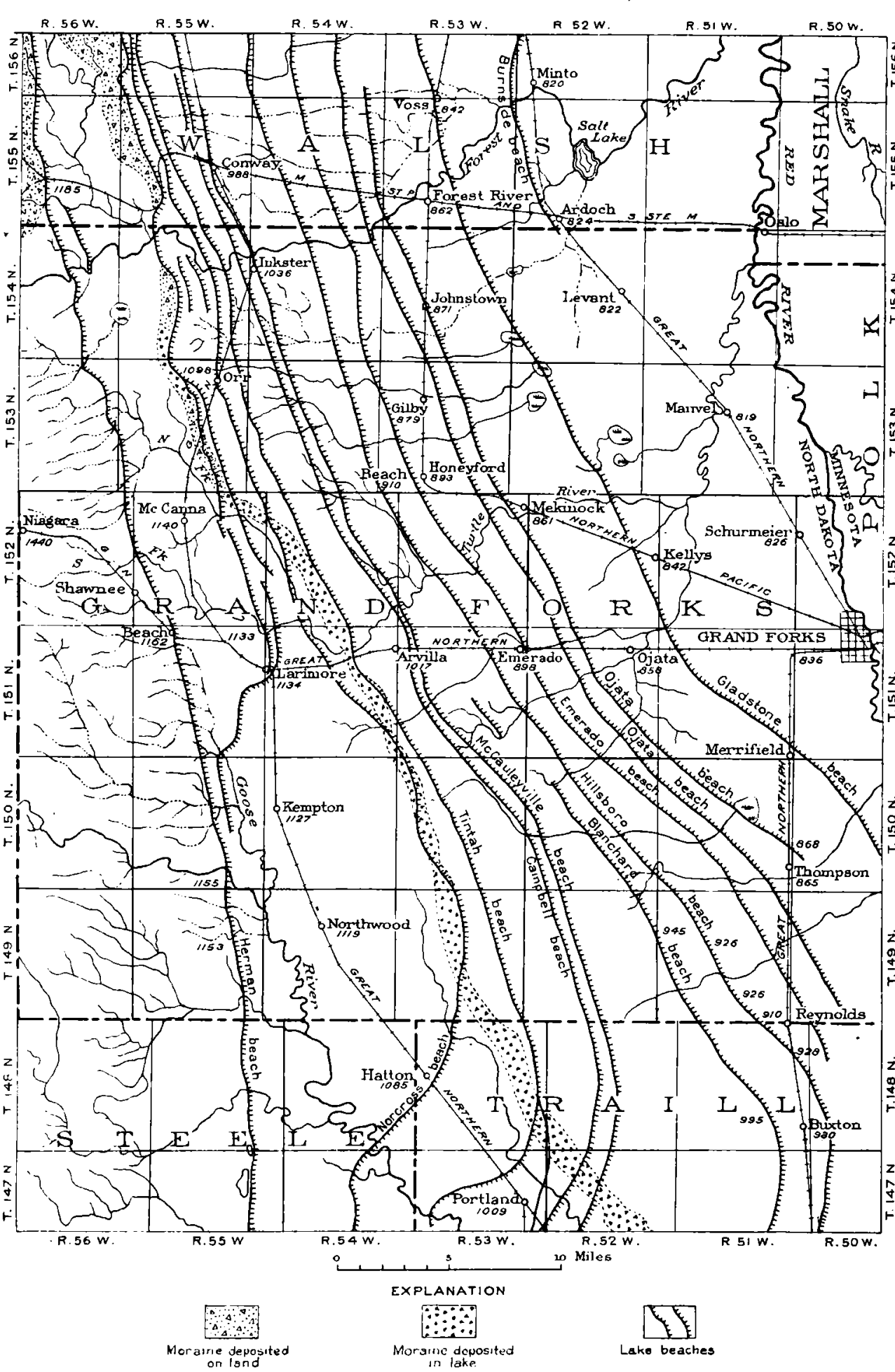

Figuan 21.-Map of moraines and western shore li nes of glacial Lake Agassiz, Grand Forks and adjoining counties, N. Dak. From Upham's Plate XXIX. Figures sbow altitude in feet above sea level

N. Dak., the most conspicuous beach is at about 1,060 feet. Outside of this is a relatively weak beach in southeastern Glendale Township, with an altitude of about 1,070 feet, but in the central part of the town- ship, in sections 15 and 16 , as noted above, there is a strong beach with an altitude of 1,080 feet, whose southeast end drops to 1,070 feet in section 22 . It makes a similar drop to the north in the southern part of the Wahpeton quadrangle, thus coming down at each end to a level in harmony with that of the Herman beach.

Along the Herman shore in the southwestern part of the Wahpeton quadrangle, both southeast and northwest of Hankinson, there are dunes which rise to various heights above the beach, a few points on those northwest of the village being over 1,200 feet above sea level, or 125 to 150 feet above the level of Lake Agassiz at the Herman beach stage (about 1,070 feet). The beach is well defined at this level in the eastern part of the Wyndmere quadrangle along the south side of the Wild Rice River. It passes one section corner where an altitude of 1,074 feet is recorded. The altitude is similar for a few miles north from the Wild Rice River, being 1,068 feet where the beach is crossed by the Northern Pacific $1 \frac{1}{2}$ miles west of Wyndmere.

Northwest of Wyndmere there is a large area of dunes in western Richland County and eastern Ransom County with an altitude above the level of the Herman beach, but flat areas among and around the dunes are shown by the Wyndmere topographic map to be between 1,065 and 1,075 feet above sea level and thus close to the level of the Herman beach. The waters of Lake Agassiz may have completely encircled this dune area, and there may have been strips of water in the flat areas among the dunes at the Herman beach stage, but if so the water was probably very shallow. The mode of deposition of this large body of sand has not yet been determined. Upham called it the Shey- 
enne delta, but it seems to lack definite connection with the Sheyenne River. The dune area does not border the river closely, but sets in 3 to 4 miles east of it, as may be seen by reference to the Wyndmere topographic map. Possibly the sand is largely a contribution from the ice sheet as the ice border was melting back to the northeast, with later wind action to produce the dunes. It is doubtful if the waters of Lake Agassiz produced much shifting of the sand or other modification of the deposit.

The Herman beach seems to be about 1,080 feet above sea level at the place where the Sheyenne River entered the lake in the southwestern part of Shenford Township, Ransom County. The west bluff catches the 1,080-foot contour in sections 8,17 , and 20 of that township, but the lake plain east of the river opposite these sections is below that contour, with altitudes recorded on the Wyndmere map as 1,065 to 1,077 feet. Near Sheldon Junction, in the southeast part of the Tower quadrangle, there is a smooth surface about to the 1,100 -foot contour, but Willard reports the general level of the Herman beach in that vicinity to be about 1,085 feet. In the Casselton quadrangle the beach is near the 1,100-foot contour clear to the northern limit of the quadrangle, at latitude $47^{\circ}$. It is 30 feet lower here than in the same latitude on the east shore of Lake Agassiz, as appears below. Upham found the interval between the highest and lowest Herman beaches on this west shore in latitude $47^{\circ}$ to be about 15 feet. $\mathrm{He}$ put the ordinary lake level for the highest beach at 1,090 feet, though he found the beach in places at 1,100 feet.

$67665-32-10$
It was determined by Upham that the rate of rise of the Herman beach on the west shore increases from south to north. The highest Herman beach rises 35

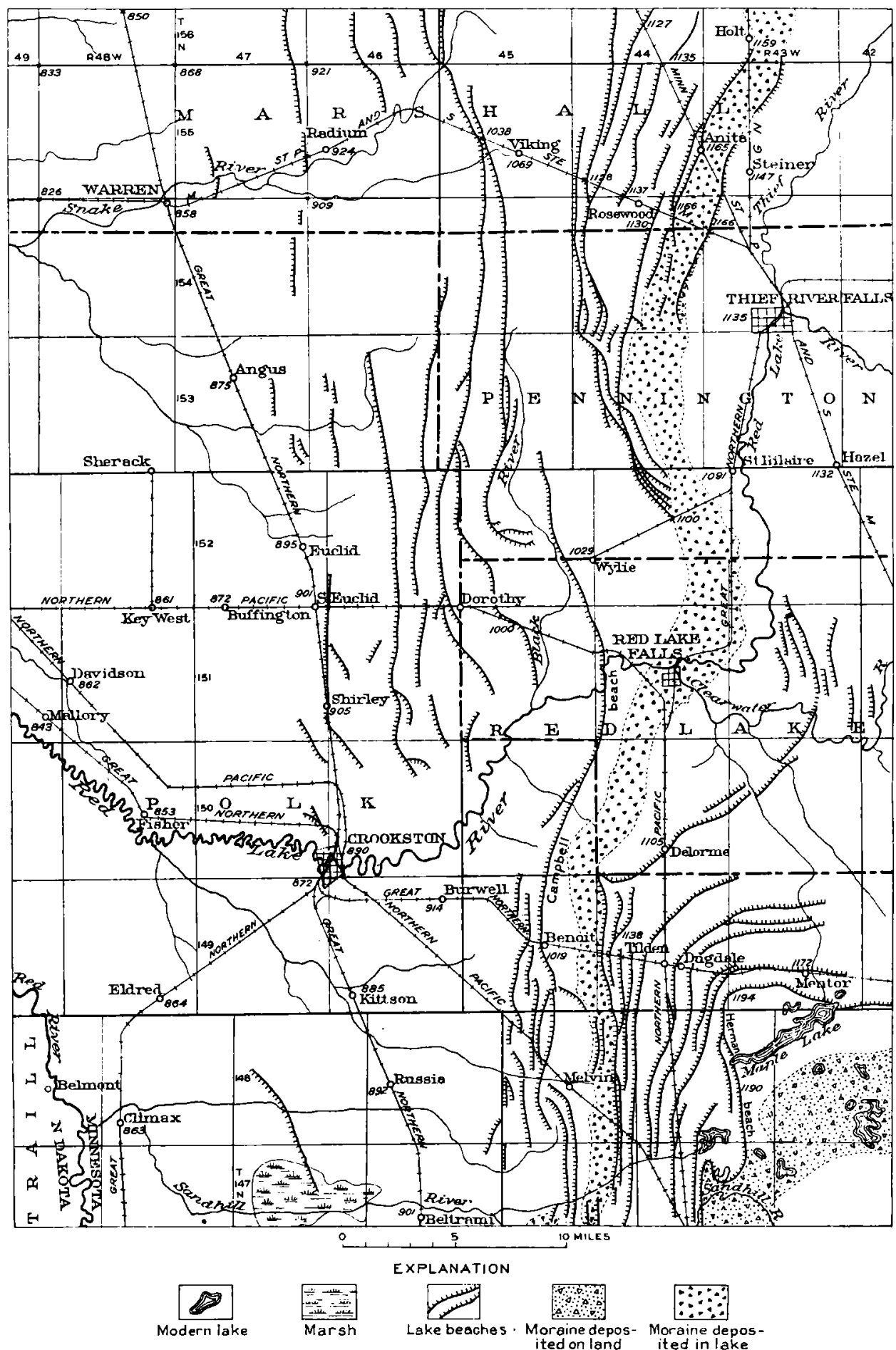

Figori 22.--Map of moralnes and shore lines of eastern part of Lake Agassiz Basin, Polk and adjacent counties, Minn. Revised by Frank Leverett from Upham's Plate XXVI. Figures show altitude in feet above sea level

feet in the first 75 miles, 60 feet in the second and 80 feet in the third, which ends near the international boundary. ${ }^{48}$ The shore has a trend west of north, 
making about $6 \check{5}$ miles west in 225 miles north. Of this 65 miles about 42 miles, or nearly two-thirds, is made in the southern 75 miles, and this is probably an important factor in giving a low rate of uplift, as

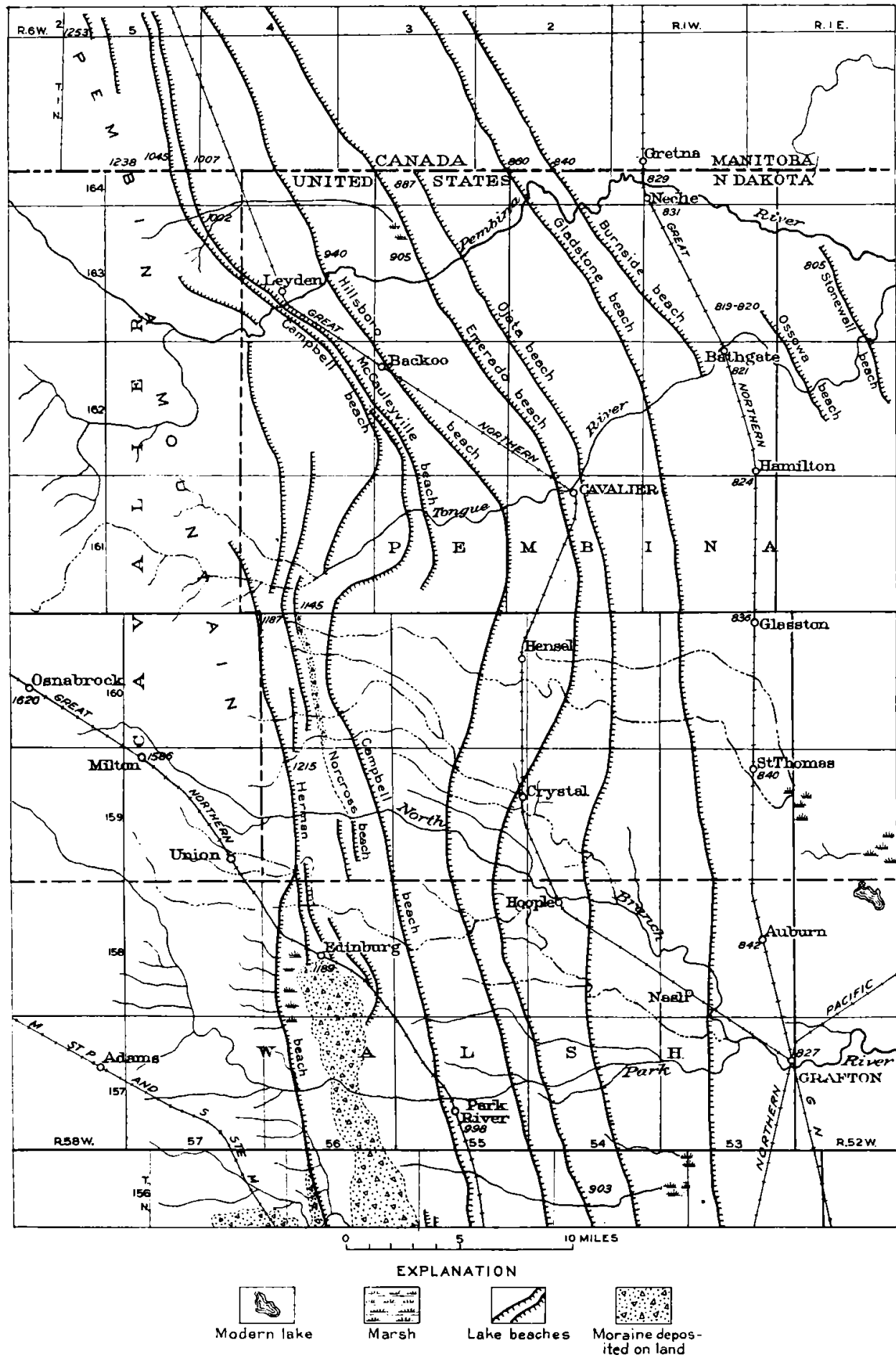

FIGURE 23.-Map of western shore lines of glacial Lake Agassiz near the international boundary in North Dakota and Manitoba. From Upham's Plate XXX. Figures show altitude in feet above sea lerel

the trend is farther from the tilt line than in the two 75-mile sections to the north. As the trend in the second and third sections is about the same, the difference there represents more accurately the increase in rate in passing northward. As interpreted by Upham the splitting of the Herman beach amounted to but 5 feet in the southern 75-mile section, 25 feet in the second, and 45 feet in the third, the northward ascent of the highest Herman beach being 175 feet and of the lowest 130 feet at the international boundary. The amount of cutting at the head of the outlet during the Herman beach stage he estimated at 10 feet.

Eastern shore in Minnesota.-As indicated on Plate 1 , the east shore of Lake Agassiz in Minnesota has a northward trend for about 140 miles from the south end of the lake, followed by an eastward trend for about 175 miles and a northward turn into Canada. Throughout its course in Minnesota the highest shore appears to have been developed in the Herman beach stage, but whether the earliest ridge of the Herman series of beaches extends clear through to the international boundary has not been definitely settled. The northward-trending part of the shore shows a marked northward rise (figs. 16, 18, $20,22)$, and the eastwardtrending part a marked eastward rise as well as a northward rise.

There is only 10 feet rise on the east shore in about 28 miles in a direction east of north from the south end of the lake bed to latitude $46^{\circ}$, at the north edge of the Herman quadrangle, or from 1,065 to 1,075 feet above sea level. The tilting may not extend to the south end of the lake bed. There is about 20 feet rise in the same distance from latitude $46^{\circ}$ in a course west of north, or farther from the supposed direction of the tilt line than in the part to the south. Between latitude $46^{\circ}$ and $46^{\circ} 30^{\prime}$, about 35 miles, there is a rise of 30 feet, the beach being 1,105 feet above sea level where crossed by the Northern Pacific Railway between Rothsay and Lawndale. To reach a similar 
altitude on the west shore one must pass to latitude $47^{\circ}$. An isobase connecting these points trends nearly west-northwest. In latitude $47^{\circ}$ on the east shore, near Muskoda, Minn., the highest beach is 1,130 to 1,135 feet above sea level. A similar altitude is reached on the west shore near latitude $47^{\circ} 30^{\prime}$. The altitude on the east shor'e in latitude $47^{\circ} 30^{\prime}$, near Fertile, Minn., is about 1,175 feet, or 40 feet higher than on the west shore. This altitude is reached on the west shore a little south of latitude $48^{\circ}$. Thus far the isobases are about parallel, and the tilt line trends north-northeast. But farther north the tilt line appears to trend more to the east. The altitude of 1,230 feet reached by the highest beach on the west shore at the international boundary is reached on the east shore near Trail, Minn., the beach being 1,237 feet above sea level where crossed by the Minneapolis, St. Paul \& Sault Ste. Marie Railway midway between Trail and Gully. A line connecting these points runs nearly northwest. W. A. Johnston reported to the writer that the tilt line bears still more to the east in Canada. The tilt lines thus show a convergence toward a high area east of Lake Winnipeg. This feature may have considerable significance in showing where the ice sheet had great thickness. The bearing of striae, as given by Upham, ${ }^{48}$ indicates that from this high area the ice had a pronounced southwestward movement into the area covered by Lake Agassiz. The radiation of ice from the so-called Keewatin center west of Hudson Bay thus seems to have been of much.less extent than is commonly represented on maps that aim to set forth the limits of the dispersion areas of the Laurentide ice sheet.

The Herman beach shows a remarkable rise eastward from the turn in the shore in Polk County, Minn. (See fig. 22.) From about 1,190 feet above sea level at that turn it rises to 1,270 feet at Redby, on the south shore of Lower Red Lake, and 1,300 feet at the crossing of the Minnesota \& International Railway northeast of Gemmel. This rise of 110 feet is made in a distance of 110 miles east and 24 miles north-that is, in an east-northeast direction. It is thus fully as great an eastward rise as the northward rise in the part of the shore that comes up to Polk County from the south and supports the view that the tilt lines in northern Minnesota trend northeast rather than north-northeast. In the region to the east of the Minnesota \& International Railway in eastern Koochiching County and northern St. Louis County there is considerable difficulty in determining what beaches and other shore features pertain to Lake Agassiz and what to the ponding prior to Lake Agassiz noted above. It is thought, however, that a shore line at about 1,360 feet above sea level on the northeast

40 Upham, Warren, op. cit, pl. 16. border of the plain drained by the Littlefork River was formed by the Lake Agassiz waters, as it is too low to connect with the outlet across the Mesabi range. This beach also encircles a prominent ridge south of Net Lake. A delta on the Sturgeon River in the southern part of T. 61 N., R. $20 \mathrm{~W}$., in western St. Louis County, at an altitude of 1,320 feet, seems to mark the highest shore of Lake Agassiz there. A delta on the Bigfork River in sec. 27, T. 63 N., R. 26 W., in southern Koochiching County, is thought to mark the highest shore at 1,300 to 1,310 feet. It is possible, as already indicated, that the highest member of the Herman series of beaches does not extend to the eastern limits of the lake, but the amount of rise of the shore there seems to favor its being one of the higher members of the series.

On the crest of a morainic ridge at Gemmel there is a narrow ridge of sandy gravel which bears some resemblance to a lake bar, but it stands about 30 feet above the definite beach crossed by the railroad 4 miles northeast of Gemmel and seems more likely to be due to local conditions of ponding in connection with the recession of the ice border than to the waters of Lake Agassiz. It was not noted elsewhere.

The highest beach of Lake Agassiz shows a remarkably higher rate of rise in the vicinity of the place where it turns from a northward to an eastward course. It rises 20 feet, from 1,175 to 1,195 feet, in 12 miles north from the Norman Polk County line. The shore there turns eastward and makes a rise of 20 feet more in 12 miles to Erskine. The distance on a line running northeastward from the Norman-Polk County line to Erskine is only 17 miles. As indicated above, this seems to be about the direction of the tilt line. The rise of 40 feet in 17 miles is about double the usual rate in this shore line. The cause for such an exceptional rate of rise is not apparent, but it may have some relation to the border of the ice sheet and show a combination of uplift and ice attraction.

Lower members of the Herman series of beaches.At a few places in northern Minnesota the altitudes of lower members of the Herman series of beaches have been accurately determined from railroad profiles or from topographic maps. These are listed below in succession, from a point near the turn in the shore in Polk County eastward into Koochiching County.

The highest beach at this turn is 1,195 feet above sea level, and lower ones are reported by Upham at levels $8,15,30$, and 45 feet below.

On the Minneapolis, St. Paul \& Sault Ste. Marie Railway near Trail the beaches referable to the Herman series are 1,237, 1,215-1,220, and 1,189 feet above sea level, giving 48 feet as the amount of splitting.

At Redby, on the south side of Lower Red Lake, the railway profile shows beaches at $1,270,1,246$, and 1,220 feet, thus giving 50 feet as the amount of splitting. 
Along the Minnesota \& International Railway northeast from Gemmel beaches are crossed at 1,303, 1.265, $1,258,1,248$, and 1,237 feet, thus giving 66 feet as the amount of splitting.

On the Minnesota, Dakota \& Western Railway in Koochiching County beaches are crossed at $1,315,1,303$, $1,27 \%$, and 1,265 feet, thus showing 50 feet of splitting. Perhaps the entire series is not embraced in this interval.

On the Duluth, Winnipeg \& Pacific Railway in northwestern St. Louis County beaches were noted at 1,365 feet near Kinmount and 1,348 feet 2 miles north of Cusson, which are probably lower members of the Herman series of beaches.

On the high area north of Upper Red Lake, which Upham $^{50}$ supposed stood above the Lake Agassiz waters and to which he applied the name "Beltrami Island," there are beaches at several levels up to about 1,300 feet. The highest points in the area are sand dunes and these rise slightly above 1,300 feet. Gravelly bars standing above 1,290 feet are found in secs. 18,19 , and 20, T. 159 N., R. 33 W.; secs. $10,11,14$, an.] 15 , T. 159 N., R. 34 W.; and secs. 7, 8, 9, 16, 17, and 18, T. $159 \mathrm{~N} ., \mathrm{R} .35 \mathrm{~W}$. It is probable that these bars are at about the highest level reached by the Lake Agassiz waters, for they lie near the probable position of the isobase for 1.300 feet, extended northwestward from the highest Herman beach near Gemmel. Gravel beaches encircle this high area at levels lower than the bars above noted. Those between 1,290 and 1,250 feet, and possibly a beach at about 1,230 feet, are thought to pertain to the Herman series of beaches.

There is a very prominent gravel bar running north from the west end of Lower Red Lake, which in places has a relief of about 50 feet above bordering swamps and whose highest points catch the 1,250-foot contour. This bar falls within the range of the Herman beaches, but it is difficult to account for the development of so high a ridge by lake action, as it does not connect with higher land from which the material could have been derived. The writer did not have opportunity to examine the ridge but obtained knowledge of it from the topographic map and from descriptions given by settlers in neighboring areas. It may prove to be a glacial feature, an esker rather than a shore line, which was covered later by lake waters.

In the northward-trending part of the Lake Agassiz shore a splitting of the Herman beach is found nearly as far south as latitude $46^{\circ}$. The interval between the upper and lower limits of the Herman series of beaches is only 10 to 15 feet there, but it increases gradually northward, and in southern Clay County, between Barnesville and Muskoda, it reaches 25 feet. This increases to at least 45 feet in Polk County, where the shore turns eastward.

\footnotetext{
${ }^{80}$ Upham, Warren, Am. Geologlst, vol. 11, pp. 423-425, 1893.
}

Character of the Herman shore lines.-There are but few places where either the highest shore line or any of the later ones has the form of a cut bluff. The common feature is a gravelly ridge, standing several feet above the land on the lakeward side and 2 to 5 feet above the land on its immediate outer border. The encroachment of the lake on the land was so slight, compared with that of the modern Great Lakes, that Upham inferred that the shore lines were formed very rapidly and that the whole duration of Lake Agassiz was equivalent to but a small fraction of the time the present Great Lakes have been developing their shores. It is probable, however, that he underestimated the duration of Lake Agassiz, for the work done by the outlet in cutting away the rock barrier hetween St. Paul and Fort Snelling by a receding cataract would probably require several thousand years, and this recession occupied only part of the life of Lake Agassiz.

There is a great amount of swamp land in the bed of Lake Agassiz in northern Minnesota. In places the peaty growths have extended over the gravel ridges as well as the intervening flat tracts. But more commonly the ridges are still exposed and support a vigorous tree growth, while the swamps are a muskeg, with only stunted trees. In the General Land Office plats the courses of the dry strips marking the beaches are represented for the greater part of their length, notably in Koochiching County (see fig. 16) and Lake of the Woods County.

In western Minnesota, where the shore has a northward trend, there was but little forest land, and the prairie was fairly well drained between as well as on the gravel ridges. The ridges there stand out so clearly as to be readily mapped, and the character of the lake bed is well shown. The extent of clay and of sand is set forth on Plates 1 and 2.

\section{NORCROSS SHORE IINES}

The second beach of Lake Agassiz was named Norcross by Upham, ${ }^{\text {s1 }}$ from a village situated on it near the south end of the lake. In its southern portion, south of latitude $46^{\circ}$, it is generally less than 1,050 feet above sea level; but it catches the 1,050-foot contour just south of Norcross and also east of the head of the outlet. In the southeastern part of the White Rock quadrangle the beach turns south in sec. $35, \mathrm{~T}$. 127 N., R. 47 W., and four parallel bars are developed, three of which are just above the 1,050-foot contour and one below it. In the part of the White Rock quadrangle north of the outlet the beach is very near the 1,050-foot contour but usually just under it. There are places in the Chokio and Herman quadrangles where it is nearly down to the 1,040 -foot contour.

\footnotetext{
n Upham, Warren, U. S. Geol. Survey Mon. 25, pp. 383-396, 1896.
} 
The ordinary altitude of the lake in this south end may thus have been not far from 1,040 feet. This is 10 feet higher than Upham's estimate but is more nearly in accord with the levels afforded by the recent topographic maps.

Upham's data for the west shore make the Norcross beach 1,055 feet above sea level in the latitude of Fargo, 1,090 feet in the latitude of Grand Forks, and 1,145 feet at the international boundary. A lower member at the international boundary stands at 1,130 feet.

On the east shore the beach rises above 1,050 feet in the southern part of the Wendell quadrangle, just north of laitude $46^{\circ}$, and shows a rise of about 70 feet from that place northward 120 miles to the point where it is crossed by the Great Northern Railway near Tilden, in Polk County. There are three gravel ridges crossed by this railroad which Upham classed as Norcross, and their altitudes are given as 1,092, 1,114, and 1,120 feet. The lowest of these rises above 1,100 feet at Delorme, 5 miles farther north, and runs northeastward from that place to the Clearwater River at Terrebonne, as the strongest of the Norcross series of ridges. Weak ridges thought to belong to the Norcross series are found 10 miles farther east, up the Lost River, about 4 miles west of Oklee, Red Lake County.

From the Lost River the course of the Norcross series of shore lines is directly away from that of the Herman series. Instead of running eastward they take a course west of north A weak ridge, probably the highest Norcross, comes to the Minneapolis, St. Paul \& Sault Ste. Marie Railway about 2 miles southeast of Plummer, and several ridges with northward trend are found west of Plummer between the Clearwater and Red Lake Rivers. These are all somewhat above 1,100 feet.

There was a bay extending up the Red Lake River beyond St. Hilaire, west of which the Norcross shore lines set in along the crest of the Holt water-laid moraine. These radiate out into the bay at their south ends. The highest ridge rises above an altitude of 1,150 feet directly west of Thief River Falls and reaches 1,166 feet where crossed by the Minneapolis, St. Paul \& Sault Ste. Marie Railway at the line of Pennington and Marshall Counties. Lower ridges of the Norcross series, at about 1,130 feet, are crossed by this railroad at and west of Rosewood. A disjointed set of ridges was developed along this waterlaid moraine entirely across Marshall County to Homolka, in southern Roseau County. A strong ridge with radiating bars at its southwest end sets in 4 miles west of Middle River village and runs through to Homolka. It is 1,177 feet above sea level where crossed by the Great Northern Railway, a mile north of Middle River, and 1,190 feet in the vicinity of Homolka. The ridge is double-crested much of the way from Middle River to the Roseau County line. The outer ridge there turns east, but the inner one continues northeast about 4 miles, hooks around to the south, and dies out. For several miles east from Homolka the altitude is too low for this shore line, but the surface rises high enough to catch it about 2 miles northeast of Thief Lake, and a network of shore lines is found thence eastward past Randen to the line of Marshall and Beltrami Counties. Some of them are above 1,200 feet and one point near Randen is 1,214 feet above sea level. There is another low marshy tract between these ridges and the South Fork of the Roseau River, but north of that stream, from Skime eastward nearly to Penturen, there is a double ridge standing above 1,200 feet that seems to fall in the Norcross series. Another ridge, also above 1,200 feet, runs northeastward from Skime to the North Fork of the Roseau River. West of this area are ridges below the 1,200 -foot contour which may fall in the Norcross series.

The Norcross series may also embrace ridges in northern Marshall County that are 20 to 30 feet lower than the strong ridge running from Middle River to Homolka. However, as indicated below, these may prove to be Tintah beaches. Two of these ridges come into Roseau County east of Strathcona and run northeastward past Benwood, becoming united before reaching that place, and attaining an altitude of 1,170 feet there. About 3 miles east of Benwood the ridge swings around to the south and sends out radiating bars into a swamp east of Homolka.

From the North Fork of the Koseau River a set of strong gravel ridges runs northward several miles into the southern part of T. 161 N., R. 37 W., where they reach an altitude of 1,250 feet. An abrupt turn is there made to the east, and a ridge, double in places, runs past the village of Clear River along or near the Lake of the Woods-Roseau County line nearly to the east end. Thence disjointed ridges standing between 1,200 and 1,250 feet above sea level extend southeastward on the northeast slope of the high tract that Upham called "Beltrami Island." It is thought that the ridges below 1,250 feet may pertain to the Norcross series and those above to the Herman series.

The Norcross series may be represented on some of the islands in the great muskeg that lies north of Upper Red Lake, as the altitude is about the same as they should have (slightly above 1,200 feet), but the writer has not examined any of these islands. The Norcross series is also probably represented in strips of dry land running eastward from Upper Red Lake, near the line of Tps. 153 and 154 N., Rs. 30, 29, 28, and $27 \mathrm{~W}$., whose altitude is a little above 1,200 feet. A more prominent strip of dry land a few miles farther north, in Tps. 155 and 156 N., Rs. 29, 28, 27, and $26 \mathrm{~W}$., is also of farorable altitude to carry the Nor- 
cross series of beaches, being a little above 1,200 feet. The delta of the Bigfork River at the Norcross beach stage appears to have been at Big Falls, where there is a plain of sandy gravel at about 1,220 feet. The Norcross series of beaches has not been definitely identified by the writer east of the Bigfork Valley.

The difference in the altitude of the highest and lowest members of the Norcross series at the northernmost places where they are found in Minnesota appears to be somewhat less than 50 feet, and the highest altitude reached by a Norcross beach in the State is not far from 1,250 feet. That altitude is reached at the line of Tps. 160 and 161 N., R. 37 W., and it may be reached or exceeded in eastern Koochiching County or northwestern St. Louis County. The line of 'Tps. 160 and $161 \mathrm{~N}$. is about 210 miles north of the south end of Lake Agassiz, and the increase in altitude is 210 feet. The eastward component is only 65 miles, so the average rate of 1 foot to the mile between the points named may not fully represent the rate on the tilt line, as that presumably runs farther to the east. It appears also that more than two-thirds of the uplift is found in the northern half of the 210-mile interval. It should be borne in mind, however, that the easterly component seems to be much more influential in the northern half than in the southern half.

There is even less cut bluff in the Norcross shores than in the Herman. They embrace some of the most prominent gravel ridges developed by this glacial lake, the relief being in many places 10 feet and locally 20 feet above bordering or intervening strips. From northern Marshall County eastward the bordering land is largely swampy, but to the south it is nearly all good agricultural land.

\section{TINTAH SHORE IINES}

The name Tintah was applied by Upham ${ }^{52}$ to shore lines that stand third in the series, the name being derived from the village of Tintah, in northeastern Traverse County, Minn. There was considerable deepening of the outlet during this lake stage, and beaches are found near the head of the outlet at several levels between 1,020 and 1,000 feet above the sea. At this lake stage the Jim's Valley outlet, in northeastern South Dakota, was abandoned, but the waters discharging from Lake Agassiz surrounded a large island east of the north end of Lake Traverse and covered a shallow channel about 4 miles wide on the east side of the island. The Mustinka River comes into Lake Traverse through this channel. The highest part of this island carries a bar of the Norcross beach stage, with an altitude between 1,040 and 1,050 feet. Most of the island stands between 1,020 and 1,030 feet. A low bluff that was cut during the Tintah beach stage bor-

\footnotetext{
s2 Upham, Warren, U. S. Geol. Survey Mon. 25, pp. 396-406, 1896.
}

clers the channel east of it, extending from the 1,020foot contour down below the 1,010-foot contour. The deepest part of the channel, where it connects with Lake Traverse at the south end of the island, is down to the 990-foot contour. A series of gravel ridges was developed at the north end of the island, the highest about 1,020 feet above sea level and the lowest 1,000 feet.

The Tintah beaches show marked variations in strength, there being well-defined gravel beaches in certain sections, whereas in neighboring sections there is scarcely a trace of shore action at the same level. It is probable that these differences depend mainly on the slope or rate of descent of the plain on the lakeward side, there having been but little wave action where the descent is very slight.

Upham put the altitude of the highest Tintah beach at the outlet at 1,015 feet, and of the lowest at 1,000 feet. He found a rise of 20 feet in the highest Tintah beach at the latitude of Fargo and of 17 feet in the lowest.

In the latitude of Grand Forks he found a rise of 50 feet in the highest Tintah beach and 45 feet in the lowest; at the international boundary, 90 feet in the highest and 80 feet in the lowest. On the east shore at Barnesville Upham found the highest Tintah beach to be at 1,030 to 1,035 feet above sea level and the lowest at 1,015 to 1,018 feet. His notes on the area farther north are very meager, but he states that the Tintah beaches are at 1,060 to 1,073 feet near the line of Norman and Polk Counties, about 60 miles from Barnesville. He also interpreted as Tintah a series of beaches on the moraine southwest of Thief River Falls, whose crests were reported to him to be $1,050,1,086$, 1,088 , and 1,092 feet above sea level. It is a question whether the highest of these should be put in the Norcross series or in the Tintah, but the one at 1,050 feet is probably Tintah. There is also some question as to the correctness of the altitudes here reported. The higher beaches on this moraine appear to be above 1,100 feet in that vicinity.

The difficulty of distinguishing between Tintah and Norcross beaches at certain places crossed by railway lines will appear from an inspection of the following data taken from the railroad profiles.

On the Northern Pacific Railway from Fertile, in Polk County, northwest to Crookston the beaches crossed between Fertile and Kunkel have the following altitudes, starting at Fertile: 1,150, 1,145, 1,147, $1,123,1,097,1,088,1,077,1,067,1.027,1,017,1,022,989$, and 975 feet. The beaches at 1,017 to 1,027 feet belong to the Campbell series, those at 1,067 to 1,097 feet are probably Tintah, the one at $\mathbf{1 . 1 2 3}$ feet is probably Norcross, and those at higher altitudes are Herman beaches. 
On the Northern Pacific Railway from Fertile, in Polk County, westward to Burwell the following beach altitudes are found, the highest Herman beach being just east of Erskine at 1,216 feet, and the next beach, 12 miles west, at 1,172 feet : $1,216,1,172,1,156$, $1,138,1,123,1,115,1,103,1,101,1,096,1,087,1,076,1,002$, $1,000,973,972$, and 932 feet. Burwell is 920 feet above sea level. In this series there is a cut bank back of the 1,002-foot Campbell beach extending up to 1,018 feet. Then comes a rise of about 60 feet before a beach is found, at 1,076 feet. But from that beach upward the shore lines show but little vertical spacing or grouping to differentiate the Tintah from the Norcross and that from the Herman series. The Tintah may embrace the shores between 1,076 and 1,103 feet, and the Norcross may be represented by the 1,115 to 1,138 foot beaches, for the beaches from 1,156 to 1,216 feet seem likely to be in the Herman series.

The Minneapolis, St. Paul \& Sault Ste. Marie Railway from Thief River Falls westward through southern Marshall County to Radium crosses shore lines at altitudes of $1,166,1,152,1,144,1,137,1,130,1,128,1,115$, $1,112,1,064,1,032$, and 1,002 feet. Radium is at 921 feet. The Campbell beach is at 1,032 feet. The beach at 1,064 feet is weak and may fall between the Campbell and Tintah beaches. The beaches from 1,112 to 1,166 feet do not seem separable into two distinct series, yet they probably include both Tintah and Norcross beaches.

On the same railway from Thief River Falls north to New Folden beaches are crossed at altitudes of $1,160,1,163,1,143,1,139,1,136$, and 1,127 feet. The Campbell beach is crossed at Karlstad at 1,056 feet, a beach 2 miles northwest at 1,018 feet, one near Halma at 1,000 feet, one 2 miles southeast of Lancaster at 921 feet, and one southeast of Orleans at 855 feet. There is thus an interval of 50 feet or more above the level of the Campbell beach that has no definite beach, so the Tintah shores here may set in above 1,100 feet and together with the Norcross embrace the series up to 1,163 feet.

On the Great Northern Railway from Thief River Falls north to Greenbush a beach at Holt is at 1,163 feet, a series of bars north of Middle River at 1,174 to 1,177 feet (see fig. 18), and two bars south of Strathcona at 1,144 feet. The Campbell beach at Greenbush is at 1,076 feet. There is thus an interval here of nearly 70 feet above the Campbell beach without a definite beach. The vertical space between the bars at 1,144 feet and those at 1,177 feet is no greater than might be corered by the Tintah shores in this high latitude. But the higher set of bars, if not the entire series, seems to fall about as naturally into the Norcross series. It remains to be determined whether the wide space between the Campbell beach and this higher series may not be the natural place for the Tintah shore lines, they being obscure in this district. In support of this view it is found that shore lines are well developed south of the Lake of the Woods and south of the Rainy River, in Lake of the Woods and Koochiching Counties, at levels but little above the Campbell shore. These may prove to be Tintah beaches. The Campbell beach in that district is 1,120 to 1,130 feet above sea level. The shores next higher are but little above 1,150 feet. Their position from Roosevelt eastward past the Wayland settlement, in northwestern Koochiching County, is shown on Plate 1. The Norcross series in that region, as stated in the discussion of the Norcross shore lines, seems to be entirely above the 1,200-foot contour.

\section{CAMPBELL SHORE LINE}

The Campbell shore line stands fourth in the series of beaches of Lake Agassiz and was so named by Upham ${ }^{53}$ from the village of Campbell, in southern Wilkin County, Minn., near the head of the outlet. The highest ridge in the vicinity of the outlet is about 984 to 990 feet above sea level. There are weaker ones below it down to about 980 feet. This beach, as well as the Tintah and Norcross beaches, swings around the northeast border of the "Sheyenne delta" in southeastern North Dakota, but the level of the lake probably had very little to do with the development of the so-called delta at any of these stages, for the "delta " apparently antedated the lake occupancy, as indicated above (pp. 126, 132).

The Campbell beach has been more definitely identified than the Tintah and Norcross beaches throughout its course in North Dakota and Minnesota and has been mapped on the west shore of the lake far to the north in Manitoba and to some extent on its east shore east of the Lake of the Woods and around an island west of that lake in southeastern Manitoba. It has been interpreted by Johnston ${ }^{54}$ to mark a return of the lake to a discharge through its southward outlet after a lower stage in which there was a discharge eastward, the cause for the return being referred theoretically to a readvance of the ice sheet to a position that blocked the eastward outlet. Johnston cites an observation made by G. M. Dawson many years before, of laminated lake clay over a gravel beach near the south worder of the Lake of the Woods-that is, lower than the Campbell beach. The exceptional strength of the veach may also be due to its having been formed during a rise in the lake level, the beach material being rolled up the slope by the advancing lake. The beach of glacial Lake Whittlesey, in the Huron-Erie Basin, seems to owe its strength to such an advance.

${ }^{33}$ Upham, Warren, U. S. Geol. Survey Mon. 25, pp. 407-426, 1896.

u Johnston, W. A., The genesis of Lake Agassiz; a confirmation: Jour. Geology, vol. 24, pp. 625-638, 1916. 
The beaches standing at 990 and 980 feet above sea level at the head of the outlet were found by Upham to rise on the west shore to 1,045 and 1,022 feet at the international boundary, about 210 miles farther north. At Cowan, Manitoba, a similar distance north of the international boundary, these beaches as determined by Johnston ${ }^{55}$ are 1,205 and 1,165 feet, respectively, above sea level. The average rate of rise in Manitoba is thus about three times as great as in North Dakota. $A$ rise of $\mathbf{4 4}$ feet is made in about as many miles from Ethelbert to Cowan, Manitoba, on a line trending west of north. The direction of maximum uplift is probably considerably east of north, and Johnston estimated that the rate might be as much as 2 feet to the mile in that district.

On the east shore the higher Campbell beach is 995 feet above sea level where crossed by the Northern Pacific Railway at Everdell, Wilkin County, Minn. It holds about this altitude as far north as Barnesville, Clay County, nearly 50 miles from the head of the outlet. It is only 1,004 feet where crossed by the Northern Pacific Railway west of Muskoda, 15 miles farther north. The branch of the Northern Pacific Railway that runs northwest from Fertile crosses ridges which are thought to be in the Campbell series at $1,027,1,017$, and 1,020 feet. The distance north from Muskoda is about 55 miles. Surveys across the beaches a little farther north show a slightly lower altitude. Thus, west of Red Lake Falls the highest beach is at 1,015 feet, and the lowest, at Dorothy, Polk County, is at 1,005 feet. In sec. 30, Red Lake Falls Township, the highest beach is at 1,013 to 1,020 feet. It is at 1,022 feet where crossed by a line of levels a little farther north, near the line of Pennington and Red Lake Counties. This is about 140 miles from the head of the outlet, and the rate of rise thus averages less than 3 inches to the mile.

From the vicinity of latitude $48^{\circ}$ northward the Campbell shore shows a markedly greater rate of rise than in the part to the south. Near Viking, 15 miles north of latitude $48^{\circ}$, it is at 1,038 feet; near Karlstad, 25 miles farther north, it is at 1,056 to 1,063 feet and shows exceptional complexity. (See pl. 1.) At Greenbush, 16 miles northeast of Karlstad, it is at 1,076 feet; near Badger, 10 miles farther northeast, at 1,086 feet; and near Fox, 9 miles farther, at 1,094 feet. The northward-trending part of the Campbell shore generally consists of two or more ridges, differing a few feet in altitude, but on turning eastward near Karlstad the shore is mainly represented by a single prominent ridge that stands several feet abore bordering plains, outside as well as inside. There is, however, a small outlying gravelly ridge south of Badger. of the same altitude as the main ridge, and north of

\footnotetext{
Eo Johnston, W. A., Canada Geol. Survey Mem. 128, pp. 11-14, 1921.
}

Fox there is a weak beach at 1,065 feet, 29 feet lower than the main ridge.

A bay extended southward up the Roseau Valley past Malung, and the beaches turn southward for several miles, on both the west and east sides. (See pl. 1.) Where the beach on the east side bears away from this bay, near Goos, it rises above the 1,100-foot contour, and it remains above that altitude eastward to the Canada line. It is about 1,120 feet above sea level from the line of Roseau and Lake of the Woods Counties east-southeastward to the Rapid River, a distance of 35 miles, and this is about the trend of the 1,020-foot isobase. On turning northeastward, in northwestern Koochiching County, it rises to 1,132 feet on the south border of the Rainy River Valley near the Manitou Rapids. The part eastward from the Roseau River is generally a single strong gravel ridge.

On entering Canada the beach runs northward on the east side of the Lake of the Woods, but its position has been mapped for only a few miles, to the limits of the farming settlement, by W. A. Johnston. A large island west of the Lake of the Woods, covering 500 to 600 square miles (see fig. 15), was found by Johnston to be bordered by the Campbell beach and to carry beaches and bars of higher lake stages up to an altitude of fully 100 feet above that reached by the waters at the Campbell stage. The altitude of the Campbell beach is between 1,100 and 1,150 feet. At certain points on the south and west shore the altitude was found to be about 1,115 to 1,120 feet, one place being near Menisino, only 6 miles north of the international boundary. A similar altitude was found at Bedford, 20 miles farther north. As this region seems likely to have suffered northward differential uplift, the shore at Bedford was probably formed at a slightly lower level than that at Menisino and represents the last part of the Campbell beach stage.

Apparently bars were formed at the Campbell stage at places where there was but little land above the lake level. Two of them are in northern Roseau County. One of these, on the south side of the Great Northern Railway, 3 to 4 miles west of Warroad, has an altitude of 1,120 feet. Another east of Pine Creek, just south of the international boundary, reaches 1,105 feet. On the north-south line between Manitoba and Minnesota, about 6 miles south of the northwest angle, there is a gravel bar at 1,137 feet, rising a few feet above the level of bordering swamps. A long gravel bar extends about 4 miles north from Gravel Pit spur on the Canadian Northern Railway, in the southeast corner of Manitoba. The south end is about $11 / 4$ miles north of the international boundary. This bar rises slightly above 1,100 feet in its highest part.

The data on altitude of the Campbell shore line in Lake of the Woods and Roseau Counties, Minn., and of 
the south border of the island in southeastern Manitoba, indicate that an isobase for 1,120 feet above sea level has a bearing between $20^{\circ}$ and $22^{\circ} 30^{\prime}$ north of west, thus indicating a tilt line in a direction bearing between N. $20^{\circ}$ E. and N. $22^{\circ} 30^{\prime}$ E. This tilt line thus seems to bear less toward the east than the tilt line indicated by the Herman beach in that part of Minnesota, as the eastward rise of the Herman beach is nearly as rapid as its northward rise. The Campbell tilt line also seems to bear less toward the east here than in the district to the west. Thus, if the isobase for 1,090 feet, which cuts the east shore near Fox, Minn., is connected with the point of similar altitude on the west shore at Arden, Manitoba, a trend of $30^{\circ}$ north of west is obtained, Arden being 150 miles west and 100 miles north from Fox. The corresponding tilt line would bear $\mathrm{N} .30^{\circ} \mathrm{E}$. This is about the same as was determined for the Herman shore in the part of the basin along the Red River farther south.

\section{MCCAULEYVILLE SHORE IINE}

The McCauleyville shore line, named by Upham ${ }^{58}$ from a small village near Kent, in western Wilkin County, Minn., stands next below the Campbell beach in the series of Lake Agassiz beaches. Upham interpreted it to have connection with the southward outlet, though its altitude is a little lower than the head of the outlet. He assumed that there had been either an upward movement of the land since that time at the head of the outlet, or a downward movement in the adjacent area to the north. ${ }^{57}$ There should be a corresponding northward descent in the Campbell beach, if this assumption is correct, but none has been noted. In the present writer's opinion it is extremely doubtful that the lake had a southward discharge at the McCauleyville stage.

Upham states that his most southern observations of the McCauleyville beach in North Dakota are in the latitude of Wahpeton, at the eastern edge of the "Sheyenne delta" near Mooreton, 25 miles farther north than the head of the outlet, at White Rock, S. Dak., and this is as far south as the present writer could trace it. But Upham's maps erroneously represent it to continue through to the outlet. On the east side of the basin the southernmost definite development of the beach appears to be about 3 miles north of Kent, where a gravel ridge coming in from the northeast makes a southward turn, forming a hook that dies out in a sandy plain at the south. This is about 40 miles from the head of the outlet. Its position farther south is stated by Upham to be based upon altitudes taken from a survey made by the Red River Valley Drainage Commission in 1886, and he gives it there a

se Upham, Warren, U. S. Geol. Survey Mon. 25, pp. 427-442, 1896

57 Idem, p. 428. southward ascent sufficient to carry it into the outlet. 'The altitude of this gravel beach is between 960 and 970 feet. That of the bed of the outlet near White Rock is 972 to 976 feet, and that of the shore on the west side near Mooreton is about 970 feet in the highest places.

Upham reported the altitude of the McCauleyville shore to be 983 to 987 feet near Wheatland, N. Dak., 996 to 998 feet near the Park River, and 1,006 to 1,007 feet near the international boundary. There is thus a rise of 35 to 40 feet in about 200 miles on the west shore. He estimated the altitude near McCauleyville to be 965 feet, near Glyndon 983 feet, and in section 33, Liberty Township, at the south side of Polk County, 990 feet. In Marshall County there are two well-defined gravel ridges west of the Campbell beach, one just above the 1,000-foot contour and the other just below it, which are probably both referable to the McCauleyville stage of Lake Agassiz. The lower one rises above 1,000 feet near the south line of Kittson County and continues as a distinct ridge past Halma to the South Fork of Two Rivers, east of Bronson. The higher ridge is less continuous but is traceable to the Minneapolis, St. Paul \& Sault Ste. Marie Railway between Halma and Karlstad, where it has an altitude of 1,018 feet. Farther north the shore may be represented in a gravel bar at 1,025 feet that runs westward from Juneberry across the northern part of T. 162 N., R. 45 W., in eastern Kittson County. It is probable that a gravel ridge along or near the international boundary east of the Roseau River, near Caribou, Minn., at 1,039 to 1,043 feet, was formed at the McCauley ville lake stage.

There thus appears to be a rise of about 70 feet in the McCauleyville shore on the east side of Lake Agassiz in a distance of about 200 miles, or nearly twice as much as on the west shore in the same interval. The trend of the isobases and the tilt line seem to be about the same as in the Campbell shore. From the international boundary on the west shore the isobase for 1,006 feet would make about 40 miles south and 60 miles east to strike the east shore in central Marshall County, or a trend $30^{\circ}$ south of east. The bearing of the tilt line is thus N. $30^{\circ} \mathrm{E}$.

\section{LOWER SHORE LINES IN MINNESOTA}

A few observations on lower shore lines were made by the present writer, which supplement to some degree the scanty notes on these beaches given by Upham in his monograph. It appears that Upham did not examine these shores north of the latitude of Grand Forks, N. Dak., nor between the latitudes of Moorhead and Crookston on the Minnesota side. He perhaps made fuller observations on the west or Dakota side of the lake. He grouped under the name Blan- 
chard several shore lines having a vertical range from 928 to 950 feet above sea level in the latitude of Fargo, from 935 to 960 feet in the latitude of Grand Forks on the west side of the lake and up to 974 feet on the east side, and from 947 to 975 feet at the international boundary. ${ }^{5 s}$

One of the Blanchard shores Upham interpreted to follow the weak morainic ridge that runs southward from Sabin, Clay County, Minn., known as Pleasant Ridge, the altitude of which is 925 to 935 feet. This is strewn with boulders and seemed to him to have a wave-washed slope. Its highest part is 15 feet lower than his estimate of the highest Blanchard level in that latitude. The position of the highest Blanchard beach in that area is not indicated on Upham's maps, but a weak beach of sandy gravel was noted by the writer in the southwestern part of Deerhorn Township and northwestern part of Mitchell Township, Wilkin County, the altitude of which is close to 950 feet. Northward from this locality for about 15 miles the border between sandy and clayey lake bed follows nearly the 950 -foot contour, but a definite beach ridge was not observed.

In northern Norman County, in Tps. 145 and 146 N., R. $45 \mathrm{~W}$, weak beaches were noted that stand above the 950-foot contour, but if differential uplift is taken into account they seem to fall in the place of the higher of the Blanchard series. The Blanchard series seems to be well displayed in southern Polk County in ridges west of Melvin at several levels, from about 970 feet down below 950 feet. A few miles farther north, between Dorothy and South Euclid, Minn., the Northern Pacific Railway crosses a series of gravel ridges thought to be the Blanchard shores at 974,960 , and 952 feet. These ridges are in the latitude of Grand Forks, N. Dak. The beaches are well developed for about 15 miles north and 6 to 8 miles south from this railroad. Notes on these beaches farther north are very scanty, but a ridge about 6 miles long at an altitude close to 950 feet was noted in the northern part of T. $155 \mathrm{~N}$. and southern part of T. $156 \mathrm{~N}$., R. $46 \mathrm{~W}$., in Marshall County.

Upham ${ }^{59}$ gave the name Hillsboro, from a village in Traill County, N. Dak., to a beach with an estimated altitude of 918 feet in the latitude of Fargo, 923 feet in the latitude of Grand Forks, and 935 feet at the international boundary, as developed on the west shore. The writer found nothing that seems to be correlative with such a shore on the east side of the lake in Minnesota. Shore features were, however, noted at a slightly lower altitude along and east of the Great Northern Railway from the vicinity of Crookston northward past South Euclid, at altitudes ranging from 900 to 916 feet, the highest being at South Euclid.

ss Upham, Warren, op. cit. (Mon. 25), pp. 445-449.

so Idem, pp. 449-454.
A beach standing a little above 900 feet has nearly continuous development from South Euclid northward for more than 50 miles, across northern Polk and Marshall Counties into southern Kittson County. What is thought to be a continuation of this shore line is crossed by the international boundary at an altitude of 953 feet about 18 miles east of the Red River. This shore seems to be a little too high to be correlated with Upham's Emerado beach, which is given an altitude of only 890 feet near the village of Emerado, west of Grand Forks, and 902 feet at the international boundary. Upham may, however, have underestimated the height of the Emerado shore, for the writer noted that its altitude near Honeyford, N. Dak., only 6 miles north of the latitude of Grand Forks, is about 910 feet. This seems to be correlative with the beach at 916 feet on the east shore at South Euclid. Furthermore, Upham's descriptions of the Emerado beach in Minnesota apply to the shore above noted and give altitudes more nearly correct than on the west shore.

A lower shore to which Upham gave the name Ojata, from a village west of Grand Forks, $N$. Dak., is represented by gravelly bars at 880 to 882 feet directly northwest of Crookston, Minn. It probably also embraces a sandy ridge about 10 miles south of Crookston that stands a little under the 880 -foot contour. Short strips of this beach were noted west of Shirley and southeast of Angus, Minn. This beach is not so well defined as the Emerado shore line.

The Gladstone beach was named from a village west of the south end of Lake Manitoba. This beach, as noted by Upham, is well developed for a few miles south of the international boundary in Kittson County, Minn., where it was followed by the old St. Paul Trail. Its altitude there is stated by Upham to be 858 to 863 feet. It is $\mathbf{8 5 5}$ feet at the Minnesota-Manitoba line, as determined by the international boundary survey. It has the form of a gravel ridge for only a few miles into Minnesota. Farther south it is cut in the lake silt, which forms a thick coating on the borders of the Red River, and presents an inconspicuous bank. Its altitude is not far from 850 feet throughout its course in Minnesota. Upham estimated its altitude on the west shore to be 845 feet in the latitude of Grand Forks and 857 feet at the international boundary. It is 875 feet at Gladstone, Manitoba, about 84 miles farther north. This beach has been identified by Tyrrell near Kettle Hill, Manitoba, 150 miles north of Gladstone, where its altitude is 920 feet. It thus shows a rise of 75 feet in about 300 miles on the west shore.

\section{CLASSES OF IAND ON THE BED OF LAKE AGASSIZ}

In the foregoing descriptions attention has been directed chiefly to the shore features, but these pertain to only a small part of the area covered by the lake. 
Wide expanses of lake bed separate the shore lines, and in these the character of the land varies greatly from place to place. The following distinct classes of land are represented:

Lake clay and clay loam, bordering the Red Rirer. Sandy, slightly pebbly deposits, not distinctly ridged.

Sandy to gravelly beaches, forming more or less distinct ridges. Pebbly sandy loam, a lake wash on loose-textured till.

Pebbly clay loam, a lake wash on clayey till.

River deltas, usually sandy to stony loam.

Swamps, with peat cover over various classes of land.

The glacial maps (pls. 1 and 2) show in a general way for the Minnesota part of the lake bed the extent of each of these classes of land. There are a few places where sand dunes have been formed on sandy parts of the lake bed, but the distribution and extent of the dunes have not been determined with sufficient accuracy to admit of mapping.

The first named of these classes of land is uniformly excellent farm land. A black soil several inches in depth has been developed on it. In the southern part of the lake area boulders are found on its surface, which may have been rafted on floating ice of the lake and dropped where it became lodged and melted.

The sandy land varies greatly in degree of fertility. Parts of it have enough loam with the sand to hold moisture through the dry seasons; other parts are not thus favored. In some parts the water table is so close to the surface that the crops can get the water they need in seasons of drought. Farming has been fairly successful over a considerable part of this sandy part of the lake bed.

The beaches are generally of low value for farming, because of the coarseness of the material and the distance down to the water table. They form excellent sites for buildings and roads and in places yield gravel suitable for road ballast.

The lake-washed till, where of loose texture, has a rather sandy soil and only a moderate coating of pebbles and boulders. 'The clayey till usually has a pebbly concentrate that coats the surface to a depth of 2 to 6 inches. It also usually carries a large number of surface boulders. The stoniness is a serious handicap to the cultivation of the land, though the soil is usually rich. There is a large element of limestone both in the pebbles and in the finer material, as the drift of this part of Minnesota was derived from the Keewatin part of the ice sheet, which came across the limestone formations of southern Manitoba.

The extent of river deltas is not shown on the glacial maps, as the borders are rather indefinite. The streams extended their deposits with each lowering of the lake level at their mouths. As noted in the discussion of the Herman beach, the mapping of deltas by Upham seems to need revision, the deposits brought in by the streams being much less extensive than he has indicated.
The areas marked as swamp usually carry peat deposits of sufficient thickness to conceal the character of the land beneath them. In some of these areas ditches several feet in depth do not reach the bottom of the peat. They are largely waste land, and their conversion into profitable areas is one of the great problems of future development.

\section{PLEISTOCENE FOSSILS}

Numerous remains of Pleistocene plants and animals have been found at various horizons in the drift and associated deposits of the region under discussion. Wood and also bones have been not infrequently found in unmodified till, having been deposited there as erratics, gathered from the original places of burial and transported by the ice sheet. Bones have also been found in glacial gravel in such widely scattered positions as to indicate that they have been transported from their original place of burial. There are a few places where wood and animal remains have been found in buried soils and peat deposits in their original place of burial. The loess deposits also are the original place of entombment of molluscan remains and in a few places of vertebrate remains. Remains of extinct vertebrates have been found in bogs on the surface of the Wisconsin drift and the beds of glacial lakes. The oldest of the organic remains antedate the invasion of the Nebraskan ice sheet and are on the border line between Pleistocene and Pliocene; the latest are on the border line between the Pleistocene and Recent.

The most comprehensive work dealing with the life of the Pleistocene epoch in this region is the volume by Baker. ${ }^{60}$ Two valuable publications by $\mathrm{Hay}^{61}$ deal with the Pleistocene vertebrates of this part of North America. Prior to Hay's report an important paper on the remains of vertebrates found in gravel pits in the Missouri Valley in western Iowa was brought out by Calvin. ${ }^{62}$ Shimek ${ }^{63}$ also discussed them in an official report and in addition presented a report on the molluscan remains found in the loess of the Missouri Valley. ${ }^{64}$ As noted in the discussion of the loess, Shimek has contributed a number of papers on the loess which bring out clearly the terrestrial as opposed to aquatic habitats of the characteristic loess fossils. ${ }^{65}$

o Baker, F. C., The life of the Pleistocene or glacial period : Illinois Univ. Bull., vol. 32, 476 pp., 57 pls., 1920.

o1 Hay, O. P., Pleistocene mammals of Iowa : Iowa Geol. Survey, vol. 23. 662 pp., 75 pls., 1914 ; The Pleistocene of the middle region of North America and its vertebrated animals : Carnegie Inst. Washington Yub. 322 A, 385 pp., 29 maps, 1924.

62 Calvin, Samuel, Aftonian mammalian remains: Geol. Soc. America Bull., vol. 20, pp. 341-356, 1909.

os Shimek, Bohumil, Report on Harrison and Monona Counties : Iowa Geol. Survey, vol. 20, pp. 315-347, 1909.

as Idem, pp. 395-399.

Tee especially 'The distribution of loess fossils: Jour. Geology, vol. 7, pp. 122-140, 1899; and The significance of Pleistocene mollusks : Science, new ser., vol. 37, pp. 501-509, 1913. 
The vertebrate remains brought to notice by Calvin were referred by him with some confidence to the Aftonian interglacial stage, and the gravel was thought to be Aftonian, but later studies by Kay ${ }^{\text {se }}$ have thrown doubt on the correctness of this reference. The doubt, however, mainly concerns the age of the gravel deposits in which the remains occur. They may prove to be of Kansan age, but the fossils belong to a fauna that flourished in that region prior to the Kansan stage of glaciation and may thus be of Aftonian age. Kay did not clear up the question of the age of the gravel, whether Kansan or Nebraskan, but he considered it the product of a glacial rather than an interglacial stage. If the gravel is found to fall in the Nebraskan stage, the fossils represent a fauna that antedated the oncoming of the Nebraskan ice sheet.

Hay ${ }^{67}$ gives the following list of species identified in the collections made in the gravel pits in the Missouri Valley:

\author{
Mammut americanum (American mastodon). \\ Mammut progenium (long-chinned mastodon). \\ Elephas boreas (mammoth). \\ Elephas columbi (Columbian elephant). \\ Elephas imperator? (imperial elephant). \\ Aftonius calvini (extinct goat). \\ Symbos cavifrons? (extinct musk ox). \\ Bison sp. (extinct bison). \\ Camelops sp. (extinct camel). \\ Equus complicatus (extinct horse). \\ Equus niobrarensis (extinct horse). \\ Equus laurentius (extinct horse). \\ Equus excelsis (extinct horse). \\ Castor canadensis (beaver). \\ Megalonyx jeffersonii? \\ Megalonyx sp. indet. \\ Mylodon harlani. \\ Ursus americanus (American bear). \\ Alces shimeki (extinct moose).
}

Of the 19 species of the above list all are extinct except two, the beaver and the bear, or about 90 per cent of the whole number.

After assembling the various finds of remains in what seem referable to the Aftonian interglacial stage Baker finds 50 species of mollusks, 25 of vertebrates, and an indeterminate number of insect wings. The mollusks all belong to species now living, but 23 of the 25 vertebrates are now extinct. He thinks that the mammalian fauna resembles most closely the fauna of the Equus zone or "Sheridan formation" of Osborn. It likewise seems to him to resemble the fauna of the bone caves of Pennsylvania, as well as the Hay Springs fauna of Nebraska. As to the climate of the Aftonian he remarks:

Kay, G. F., Recent studies of the Pleistocene in western Iowa: Geol. Soc. America Bull., vol. 35, pp. 71-74, 1924.

${ }^{\text {or }}$ Carnegle Inst. Washington Pub. 322 A, p, 296, 1924.
The Aftonian was a time of luxuriant forests, the climate was moist, and the winters were not too severe for such animals as the elephant, horse, and peccary. The types of mollusks indicate a climate not essentially different from that of to-day.

Two types of climate are recognized-a warm temperate climate, in which the naiads and other mollusks and the larger part of the mammals lived, and a cold temperate climate, in which a boreal flora flourished. Shimek interprets the molluscan fauna as representing aquatic or low-ground conditions, but the mammalian fauna suggests upland or prairie conditions. It is probable that both types of topography prevailed. It is probable also that all the species were living throughout the Nebraskan glacial stage in adjacent territory outside the ice sheet and thus formed a reserve fauna which migrated northward as soon as the Aftonian climate became favorable.

The plants found in the Aftonian peat and soil include several species of moss of the genus Hypnum. The most common woods are spruce and cedar, but tamarack and pine are also present and more rarely elm and poplar. The writer collected wood from a black till near Quincy, Ill., which is either pre-Kansan or at the base of the Kansan and hence at least as old as the Aftonian interglacial stage. The specimens were carefully sectioned and studied by Walter W. Tupper, of the botanical department of the University of Michigan, and found to represent a primitive pine. Concerning it Tupper states, "it is one of the most primitive hard pines because of the piciform pitting in its ray cells."

Although the Yarmouth was a very long interglacial stage, as shown by the erosion of the Kansan drift and development of gumbotil prior to the Illinoian glaciation, there are remarkably few identifications of the life of this stage in the region under discussion. The only vertebrate identifications are those of the rabbit and skunk made by F. W. True from specimens sent him by the present writer from peat deposits thrown out from a well near Yarmouth, Iowa, where the peat lies beneath the Illinoian drift. ${ }^{88}$ Hay $^{69}$ remarks on this point:

Although other species of vertebrates have not yet been identified from deposits recognized as Yarmouth, we may be sure that there were numerous animals occupying these prairies and forests. Ground sloths, elephants, mastodons, horses, bisons, peccaries, besides other mammals now no longer existing, had not yet become extinct in Yarmouth times. Remains of these, or some of these, will certainly be recovered.

Fossils in the pre-Illinoian loess in Rock Island County, Ill., differ from those of the surface loess in carrying Pyramidula striatella and Pupa alticola. They also contain a larger proportion of Helicina

McGee, W. J., U. S. Geol. Survey Eleventh Ann. Rept., pt. 1. p. 495, 1891. Leverett, Frank, U. S. Geol. Survey Mon. 38, pp. 42, $124,1899$.

* Hay, O. P., Carnegie Inst. Washington Pub. 322A, p. 283, 1924. 
occulta and a smaller proportion of Succinea avara. The following have been identified by W. H. Dall and C. T. Simpson:

Helicina occulta Say. Helicodiscus lineatus Say. Limnaea humilis Say (var.). Pyramidula perspectiva Say. Pyramidula striatella Anth.
Pupa armifera Say. Strobilops labyrinthica Say. Succinea avara Say. Succinea luteola Gould. Vitrea arborea Say?

The plant remains in the Yarmouth peat and soil appear to be of the cool temperate type and all of species now living, though some showing varietal differences. The pine, tamarack, and spruce suggest a cooler climate than the present in localities where they are preserved. But they probably were embedded in the early part of the Yarmouth interglacial stage, before the greatest warmth had been reached. They antedated the loess deposits, which appear to represent a warmer and drier part of that stage.

The number of species of vertebrates that have been referred to the time between the Illinoian and Wisconsin glacial stages is surprisingly greater than that of the species referred to the Yarmouth interglacial stage. It may be found that some Yarmouth fossils have been incorrectly placed in post-Illinoian time. Thus fossils found in the Driftless Area beneath the loess have been commonly referred to a time immediately preceding the loess deposition and classed as Sangamon, though evidence as to the time relations is not decisive. Vertebrate fossils found at the base of the loess in the vicinity of Alton, Ill., may also prove to be older than the Sangamon, as they were obtained on an eroded drift that seems likely to be pre-Illinoian. The fish and mammal bones found at Menomonie, Wis., are in a clay whose age has not yet been determined with certainty. These are the localities which carry the longest lists of fossil vertebrates that have been referred to the Sangamon interglacial stage.

Hay ${ }^{70}$ presents the following list of vertebrates from the Driftless Area, found chiefly in crevices in the Galena limestone :

Megalonyx jeffersonii?

Platygonus compressus. Tagassu lenis.

Odocoileus virginianus?

Cervus canadensis.

Cervus whitneyi.

Antilocapra americana.

Bison sp. indet.

Mammut americanum.
Megalonyx jeffersonii.

Equus sp. indet.

Platygonus cumberlandensis.

Sangamona fugitiva.

Cervalces roosevelti?

Rangifer muscatinensis?

Taurotragus americanus.

Symbos cavifrons.
Bison sp. indet.

Mammut americanum.

Castor canadensis.

Marmota monax.

Castoroides ohicensis.

Geomys bursarius.

Ursus americanus.

Of these 15 species only four are now living, but it is thought by Hay that none of the others require an earlier date than the middle of the Pleistocene. Concerning the age of the underlying till and the time of burial of these vertebrates Leighton ${ }^{72}$ has expressed the following view:

If the till proves to be Kansan in age, the weathering of the drift may be credited to the Yarmouth interglacial epoch, the mammalian fauma to late Illinoian or early Sangamon times, the reddish loess (in which the fossils occur) probably to the Sangumon, and the buff loess to the Iowan.

In the clay beds at Menomonie, Wis., a caribou antler, bones of the Mackinaw trout, and a leg bone of a mastodon have been found. Hay reports that marks on the leg bone seem to have been made by the jaws of a wolf. He says the explanation appears to be that the mastodon had in some way broken a limb and had died. The wolves then proceeded to devour him; they could not have broken the limb themselves. The mammal remains and also wood found in this clay are in fragments, indicating transportation from the original place of burial into the lake, but the fish remains are sufficiently intact to warrant the interpretation that the fish lived in the lake.

The bones and teeth of a reindeer were found by I'. M. Witter near the base of the loess at Muscatine, Iowa, and named Rangifer muscatinensis by Leidy. ${ }^{\text {s }}$ Hay ${ }^{74}$ quotes Shimek to the effect that the bones were in the gummy clay developed on the surface of the Illinoian drift-that is, the Sangamon soil, or Illinoian gumbotil-and he also thinks that the remains belonged to a species quite distinct from any now living. Hay states that the following species are referred, with some reservations, to the Sangamon stage in Iowa :

Mammut americanum (masto- $\mid$ Rangifer muscatinensis (caridon). Elephas primigenius (mam-
moth). moth).

Remains of plants are numerous in the Sangamon soil, but identifications of species have been made in very few localities. The range in kinds of plants is rather wide, as indicated by the list given by Baker, ${ }^{75}$ which embraces over 50 species. liam McAdams at the base of the loess in the vicinity of Alton, Ill., now deposited in the United States National Museum, includes the following species as reported by Hay: ${ }^{71}$

${ }^{70}$ Hay, O. P., Carnegie Inst. Washington Pub. 322, p. 343, 1923.

71 Idem, p. 339.

22 Leighton, M. M., Jour. Geology, vol. 29, p. 514, 1921.

${ }^{73}$ Leidy, Joseph, Acad. Nat. Scl. Philadelphia Proc. for 1879, p. 32.

* Hay, O. P., Carnegie Inst. Washington Pub. 322 A, p. 176, 1924 ; Iowa Geol. Survey, vol. 23, pp. 34, 278-281, 1914.

Ts Baker, F. C., op. clt., pp. 335-337. 
Molluscan remains, mainly of terrestrial species, are abundant in the loess that overlies the Sangamon soil and Illinoian gumbotil. Fluviatile mollusks have been found in certain localities in deposits that fall in this interglacial stage. A conspicuous example is that of the Florencia formation of Hershey near Freeport, Ill., in which he found 48 species of mollusks. ${ }^{\text {i6 }}$

Remains of several species of extinct vertebrates are embedded in peat bogs on the Wisconsin drift in Minnesota, and also in river bars of post-Wisconsin age. Three such species, Megalonyx jeffersonii, Elephas boreus, and Castoroides ohioensis, have been found within the limits of the city of Minneapolis. A peat bog near Crosby, Minn., yielded remains of Bison occidentalis, Bison bison, a reindeer, probably Rangifer caribou, and an antler of the moose Alces americanus. In river terraces in Wabasha County, Minn., have been found remains of the musk ox, probably Ovibos moschatus, and Elephas boreus. River gravel at Mankato, Minn., has yielded remains of Elephas boreus and Mammut americanum. A mastodon tusk has been found on a terrace of the Mississippi River at Minnesota City. Other places in Minnesota at which mastodon remains have been found are Fairhaven, Stillwater, Northfield, and Albert Lea.

Some of the remains found in river bars may have been derived from pre-Wisconsin deposits that were in process of erosion by the streams, but those found in the peat bogs are certainly post-Wisconsin. There is thus clear evidence that the vertebrates whose remains are thus embedded became extinct only a few thousand years ago.

In a letter in February, 1928, Baker makes the following statement concerning recent determinations on mollusks:

Intensive studies on the fresh-water deposits, as well as the loesses, of Illinois, Indiana, and Iowa indicate that as far as the mollusks are concerned there are many forms that differ varietally from those living to-day. In many aquatic deposits the lineal ancestors of several species have been observed, the difference between these and the recent forms being very marked. In several instances the species of early periods, as the Yarmouth, are different from those of the later intervals, as the Peorian. The early Wisconsin shows a large proportion of recent species with a falling off, in the land forms, of the peculiar Pleistocene varieties. It may be found that fully 25 per cent of the land fauna is extinct, taking into account the recognized varieties. This compares more favorably with the percentage of extinct forms found among the insects and mammals and appears more in accord with laws which should have affected one group as well as another.

\section{DEVELOPMENT OF PRESENT MISSISSIPPI DRAINAGE 7 ?}

As the late Wisconsin Keewatin ice melted away and its margin retreated northwestward it uncovered

\footnotetext{
${ }^{78}$ Baker, F. C., op. cit., pp. 295-296.

$\pi$ Adapted from discussion by F. W. Sardeson in U. S. Geol. Survey Geol. Atlas, Minneapolis-St. Paul folio (No. 201), p. 11, 1916.
}

a surface whose former relief had been modified by the deposition of the young gray drift and upon which a new set of streams began to flow, finding such courses as they could among the many knolls and ridges of drift. At first they were swollen with water from the melting ice and flowed with strong currents, so that they were able to cut broad valleys and do more work in erosion and transportation than at present. They were laden with clébris, partly outwash from the melting ice, partly drift from places where they were eroding, which was carried a long distance and spread out for many miles along their courses and which now forms the gravel floors of terraces along the valley of the Mississippi. Probably all the depressions were occupied by lakes and ponds, each of which discharged through the lowest point of its rim to some neighboring lower tract, and thus the courses of many streams became fixed. In time many of the lakes were drained and streams flowed across their former beds, and so by degrees the present system of drainage was developed.

The present valley of the Minnesota River must have been even then a relatively low area, along which one of the main lines of drainage was early established. By the time the ice had finally disappeared from the area two principal streams were established in it-the glacial Mississippi and the glacial Minnesota. Both were fed by melting ice in areas on the northwest, and both carried considerable débris and were actively eroding their channels. These streams joined a mile northeast of Fort Snelling, forming a stream that flowed northeastward in a new course to St. Paul and thence southward in an old valley. This stream was swift and vigorous, and it soon cut a channel through the Decorah shale to the Platteville limestone. Where it flowed off the limestone bed into the old valley a low fall was soon developed.

The glacial Mississippi had much the same drainage basin above Minneapolis as the present river, but it carried a larger volume of water and in places was a mile across, though shallow. Its bed was uneven and was being cut down in some places and filled up in others. As soon as the ice had melted out of its drainage basin the river shrank to its present normal volume and began cutting the lower terraces in the old valley.

The glacial Minnesota appears to have been a larger stream than the glacial Mississippi, being in places 2 miles wide. Like the Mississippi it flowed over an uneven bed, formed the high-level terraces from outwash in the course of the recession of the ice border, and began the excavation of these deposits. Unlike the Mississippi, however, it did not shrink to its present volume when the ice disappeared from its drainage basin, for it was long the outlet for glacial Lake Agassiz and then carried an even greater volume than before. 
DEVELOPMENT OF PRESENT MISSISSIPPI DRAINAGE

The River Warren, the stream through which Lake Agassiz had its discharge by way of the Minnesota Valley, was the main stream of the region, to which the Mississippi above Fort Snelling was only a tributary, and it cleared most of the drift out of the old valley south of St. Paul and cut terraces on the side slopes. It cut the deep gorge between Fort Snelling and St. Paul by the recession of the fall that had formed at the lower end of the gorge. When the head of the gorge passed the point where the Mississippi entered, at Fort Snelling, a fall was formed on that stream also and cut its way back to its present position at St. Anthony Falls. The main fall receded only a short distance up the Minnesota Valley beyond Fort Snelling when it came to the eastern bluff of a buried preglacial valley. On cutting away its limestone layers the fall disappeared, and the River Warren deepened the Minnesota Valley rapidly.

For several thousand years after the River Warren had begun the excavation of the gorge between St. Paul and Fort Snelling the Mississippi River above the rock strata were not quite the same; during the existence of the River Warren the Mississippi was only a tributary, but since the subsidence of the River Warren it has been the main stream. As a result of the combined influence of these factors both the older, higher channel and the newer, deeper gorge of the Mississippi above Fort Snelling are narrower than those of the River Warren. The height of the falls and the gradient of the stream both below and abore the falls have varied considerably from time to time, and the manner of recession has been rather different.

The breadth and scope of the stream and the height, and character of the falls at several stages in their history are shown by terraces and remnants of fall scarps at a number of places along the gorge. The profiles of the falls at several stages of their recession are shown in Figure 24.

The highest stage of the falls, about 75 feet, is found just above the Lake Street Bridge in Minneapolis. It resulted in the cutting of the deep lower gorge, now partly filled with rock waste, as shown in

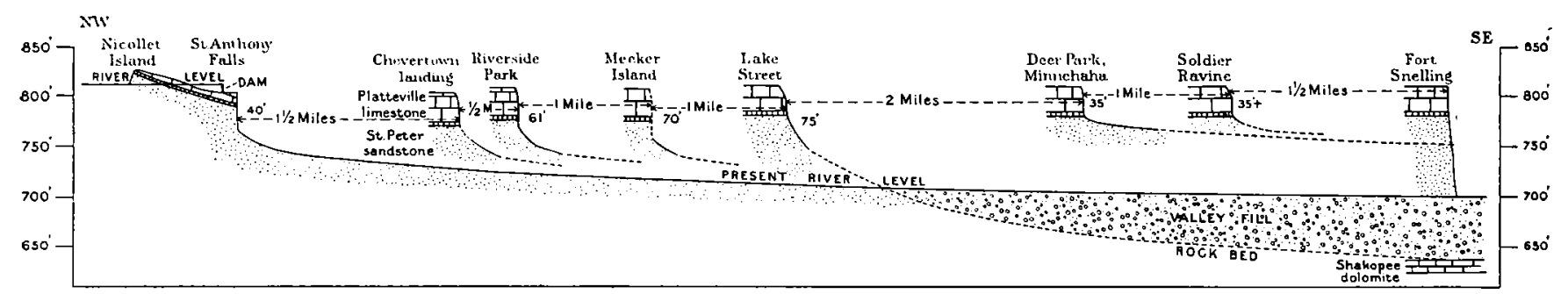

Figtre 24.-Generalized profles showing successive stages of St. An thony Falls from Soldier Ravine to the present falls below Nicollet Island. The blufi at Fort Snelling, shown at the right, is not a fall scarp. By F. W. Sardeson

Fort Snelling was flowing on the bed of the glacial Mississippi and probably had cut it down to the top of the Platteville limestone between Minneapolis and Fort Snelling. It appears that the River Warren encountered a small preglacial valley just below Fort Snelling that extended northwestward up the present course of the Mississippi for about a mile. The River Warren quickly cleared the drift in the part of this valley that crossed its path and then attacked the limetone on the west bluff of the little valley. The Mississippi likewise rapidly cleared the drift from the part of the little valley above Fort Snelling to the point where it entered that valley over the rock bluff on its north side. As the drift was scoured away a fall was formed where the river plunged into the old valley. 'This was the beginning of the falls of the Mississippi as distinguished from the falls of the River Warren. This part of the Mississippi River was formerly called the St. Anthony River, and the falls were therefore called St. Anthony Falls.

The history of St. Anthony Falls is in general similar to that of the River Warren fall, but differs in several important details. The volume of the Mississippi was much less than that of the River Warren;
Figure 24. During the last 4 miles of recession of the falls, above the Lake Street Bridge, the river while excavating the gorge in that interval has been filling up the gorge below the bridge, as shown by the valley fill in Figure 24.

The recession of the falls has been in part contemporaneous with the deepening of the Minnesota Valley by the River Warren and in part subsequent to the subsidence of that stream. This subsidence appears to have taken place when the St. Anthony Falls were in the vicinity of the Lake Street Bridge. It appears to be in consequence of this subsidence that the bed of the River Warren and the part of the gorge below the Lake Street Bridge have received the filling with river débris indicated in Figure 24, the amount of filling at Fort Snelling being about 60 feet.

The rate of recession of St. Anthony Falls in historic times has been determined by N. H. Winchell from records dating back to 1680 , when Father Hennepin saw the falls, to be about 2.44 feet a year, or a mile in 2,163 years. As the Lake Street Bridge is about 4 miles below the present position of the falls, the time since the subsidence of the Rirer Warren appears to be between 8,000 and 9,000 years. It thus ap- 
pears that the Keewatin ice was persisting near the northeast limits of the glacial Lake Agassiz down to within 9,000 years of the present time.

Eventually the recession of the ice front in Canada uncovered a low outlet eastward for Lake Agassiz, and the southward discharge ceased for a time. A readvance of the ice front closed this eastward outlet, and the lake rose to the level of the head of the southward outlet and again discharged through it. But a subsequent recession of the ice front reopened the line of eastward discharge and the River Warren subsided. Since then the Minnesota River has had virtually the same volume as at present.

Since the River Warren subsided the Mississippi has not been able to transport all the sediment brought in by its tributaries. Its bed in places has been aggraded no less than 50 feet, the current has been slackened by the raising of the river bed, and it has formed a flood plain that is occupied chiefly by swamps and lakes.

On the basis of the rate of erosion indicated above, St. Anthony Falls started about 14,000 to 15,000 years ago, the length of the gorge cut by them being about 7 miles. To estimate the duration of Lake Agassiz it is necessary to add to the somewhat more than 6,000 years involved in the cutting of the part of the Mississippi River gorge between Fort Snelling and the
Lake Street Bridge the time required for the opening of the greater part of the rock gorge below Fort Snelling by the River Warren. Earlier drainage had probably made only a small start on this task. This rock gorge is between 5 and 6 miles long, or nearly as long as that cut by the Falls of St. Anthony. But as the River Warren was a much larger stream than the Mississippi River the excavation was probably accomplished in a much briefer period than the 15,000 years required for the work by St. Anthony Falls. It might have been accomplished in less than half the time, possibly in 4,000 years or less. It is necessary also to take into account the period of interruption of flow in the River Warren when Lake Agassiz had a temporary eastward discharge. It is doubtful, however, if this covered more than a few centuries. With all the evidence taken into consideration it seems prob. able that the duration of the River Warren did not much exceed 10,000 years. By adding to this the estimated 8,000 to 9,000 years since the river subsided, the beginning of Lake Agassiz is found to have been about 18,000 years ago. It thus appears to be a rather close correlative of the glacial Lake Algonquin, as determined by estimates made on the time involved in the history of Nicgara Falls. ${ }^{78}$

7 Taylor, F. B., U. S. Geol. Survey Geol. Atlas, Niagara follo (No. 190), pp. 23-24, 1913; New facts on the Niagara gorge: Michigan Acad. Sei. Papers, vol. 12, pp. 251-265, 1929. 


\section{INDEX}

A

Acknowledgments for aid

Aftonian interglacial stage, deposits of

fossils of name of

Alden, W. C., and Leighton, M. M., quoted Altamont morainic system, in eastern South Dakota..._._.

in Iowa in southwestern Minnesota name of

north of Grantsburg sublobe outwash from relation of Gary moraine to south of Grantsburg sublobe

Altitudes in the area. 9-11 map showing _. 10

Analysis of soll near Faribault, Wis._. 17

Anoka moraine, extent and character of

Antelope moraine, extent and character of name of _._.

outwash and border drainage of

Apfel, E. T., acknowledgments to

B

Baker, F. C., quoted

144

Bemis moraine, in Iowa

in South Dakota

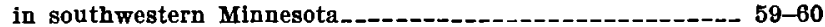
relations of Atlamont moraine to

north of Grantsburg sublobe... 61-64

on east side of Des Moines lobe_-_. 61

Beroun moraine, features of -

Bigstone morainic system, extent and character of

inner-border features of _._._._._.

outwash and border drainage of

"Bituminous" till, occurrence of 15

Blanchard beach of Lake Agassiz_._._. 139-140

Buchanan gravel, occurrence of

C

Calvin, Samuel, quoted Cambrian system in the area

Cambridge moraine, features of

Campbell beach of Lake Agassi

80

Canby moraine, extent and character of

"Carbonaceous" till, occurrence of - 15

Carboniferous period, conditions in Minnesota during

Carman, J. E., quoted

Chamberlin, T. C., and Salisbury, R. D., quoted.

Chippewa River, glacial relations of

Climate during interglacial stages.-. 110

Cloquet moraine, features of

Cordilleran ice sheet, extent of

Coteau des Prairies, features of

Cretaceous system in the area

Cromwell moraine, features of

Crow River, terraces of

Crow River morainic system, extent and character of

ground moraine of

outwash and glacial drainage associated with

relations of Altamont moraine to

Crow Wing River, glacial drainage of

D

Dakota ice lobe, general relations of

Dall, W. H., and Simpson, C. T., fossils identifled by

Delano moraine, features of

143

Des Moines ice lobe, general relations of

Devonian system in the area.

-57
14

Draco moraine, features of

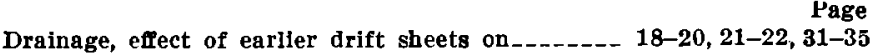
from Des Moines ice lobe.__._. $59,60,68,72,74$ from east side of Keewatin Ice sheet. from Grantsburg sublobe from St. Louis sublobe._.

from Supclior ice lobe general features of north of Mesabi iron range. of Lake Agassiz of Minnesota Valley_._. of Red River Basin. preglacial__.

Drift, drainage courses influenced by _..._._... 18-20, 21-22, 31-35 general distribution of, maps showing-- $23,29,30,58,59$, pls. 1, 2 names applied to section of, at Taylors Falls, Minn__._._. thickness of test boring showing See also names of drift sheets.

Driftless Area, vertebrates from Drumlinoid ridges, oceurrence of, in Wadena County, Minn Dunes, occurrence and character of _._._._._._- 44, 88-90, 130-131

$\mathbf{E}$

Embarrass Valley, features of 120 Emerado beach of Lake Agassiz.-_-_-_._- 140 Erskine moraine, extent and character of Esker's, occurrence and character of

Fajrmont morainic system, extent and character of Field work in the area Fond du Lac moraine, features of Fossils found in the area.....

G

Gary moraine, extent and character of relations of Altamont moraine to Geography of the area

Geology of the area, maps showing outline of

Glaclal deposits, Pleistocene, outline of $3-9$

Glacial gathering grounds, location of

Glacial lakes of the area, origin of See also names of lakes.

Glacial rivers. See names of rivers.

Glacial stages, names applied to

Glacial striae, occurrence of

Gladstone beach of Lake Agassiz... 140

Granite, occurrence of

Grantsburg sublobe of Wisconsin gray drift, dune sand of extramorainic till sheet of general relations of glacial river terraces of Rush Lake morainic system_._._._. Grasston moraine, features of Gravel plains of Iowan drift Gray drift. See Wisconsin drift.

Grout, Frank F., analyses by 17 Gumbotil, distribution and character of origin of name

H

Hall, C. W., and Meinzer, O. E., quoted._. 12 Harris moraine, features of

Hay, O. P., fossils identified by quoted _-_. Herman beaches of Lake Agassiz 142 Highland morainic system, features of Hillsboro beach of Lake Agassiz IIolt moraine, extent and character of 
$I$

Ice sheets, centers of dispersion of

extent and direction of movement of, in Minnesota, map

recession of

See also Keewatin ice sheet; Labrador ice sheet; also names of lobes.

Illinoian drift, distribution and character of

erosion in

gumbotil on

name of

Interglacial stages, names applied to

lowa, maps of, showing distribution and relations of glacial drift -

Iowan drift, distribution and character of drainage changes due to drumlinoid ridges tentatively referred to gravel plains on edges of maps showing relations of name of

pebble concentrate on

proposed reclassification of

west of Des Molnes lobe of Wisconsin drift, probable relations of

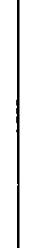


Page

Ordovician system in the area. Osars. See Eskers.

$\mathbf{P}$

Patrician ice, drift of _-_._- 52-53, 55-56, 65, 78, pls. 3, 4 movement of

Peorian interglacial stage, name of 7

Physical features of the area._-_._-_._- 9-13

Physiographic provinces included in the area, map showing ... 13

Pine City moraine, features of _._._. 79-80

Platte River, preglacial course of

Pleistocene fossils in the area

Pleistocene glacial deposits, outline of - 3-9

Pomme de Terre Valley, glacial history of

\section{$\mathbf{Q}$}

Quartzite, glacial striae on occurrence of

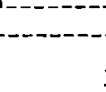

17

10,11

\section{$\mathbf{R}$}

Red drift. See Illinois drift; Wisconsin drift.

Red Eye River, glacial origin of.

Red River Basin, glacial drainage of moralnes of

Relief in the area Reports on the area_._.

Rivers. See names of rivers.

Rock formations of the area

Rush Lake morainic system, eskers of intermorainic plains of outwash and glacial dralnage associated with relation $s$ of parts of

$\mathbf{S}$

St. Anthony Falls, recession of

St. Croix moralnic system, distribution of -

features on inner border of

relation of glacial Lake Wadena to

structure and constitution of drift of

topography of _... 41

outwash from

St. Croix River Valley, features of

St. James morainic system, extent and character of inner-border district of relation of glacial Lake Minnesota to

St. Louis River, course of

St. Louis sublobe of Wisconsin gray drift, relations of Sangamon interglacial stage, deposits of fossils of

Sardeson, F. W., acknowledgments to Grantsburg sublobe of WIsconsin gray drift, description by- 78-90 quoted.
Sauk River Valley, glacial drainage of

Scope of the report._._- 2

Silurian system in the area

Soil, near Faribanlt, Wis., analysis of

on bed of Lake Agassiz, classiffcation of

South Dakota, glacial drift in, maps showing relations of

Striae, glacial, occurrence of

Superior ice lobe, glacial lakes connected with

moraines of, in Minnesota

outwash from

$\mathrm{T}$

Taylors Falls, Minn., section of bluff at____ 17

Terraces, of glacial rivers.... 87-88

Tertiary period, conditions in Minnesota during 14

Thlef River Falls, record of boring at 118

Thompson moraine, features of

Tintah beaches of Lake Agassiz

Topography of the area, general features of

$\mathbf{U}$

Udden, J. A., quoted._. 19

Upham, Warren, acknowledgments to

$122,124,125,128,129,130,131,132$ quoted._...

$\mathbf{V}$

Vermilion Lake, features of

\section{$\mathbf{W}$}

"Waconia" moraine, location of

Wing River Valley, glacial drainage of

Wisconsin drift, fossils in general relations of gray drift, in Minnesota River Basin

in Red River Basin

of Des Moines lobe_-_- 56-78

of Grantsburg sublobe.

maps showing distribution of

name of -.. 5

red drift, description of

Wisconsin glacial stage, divisions of shifting of ice sheets during

Wisconsin River Valley, pre-Illinoian drift in

Wright moraine, features of

\section{$\mathbf{Y}$}

Yarmouth interglacial stage, deposits of erosion during fossils of _. 



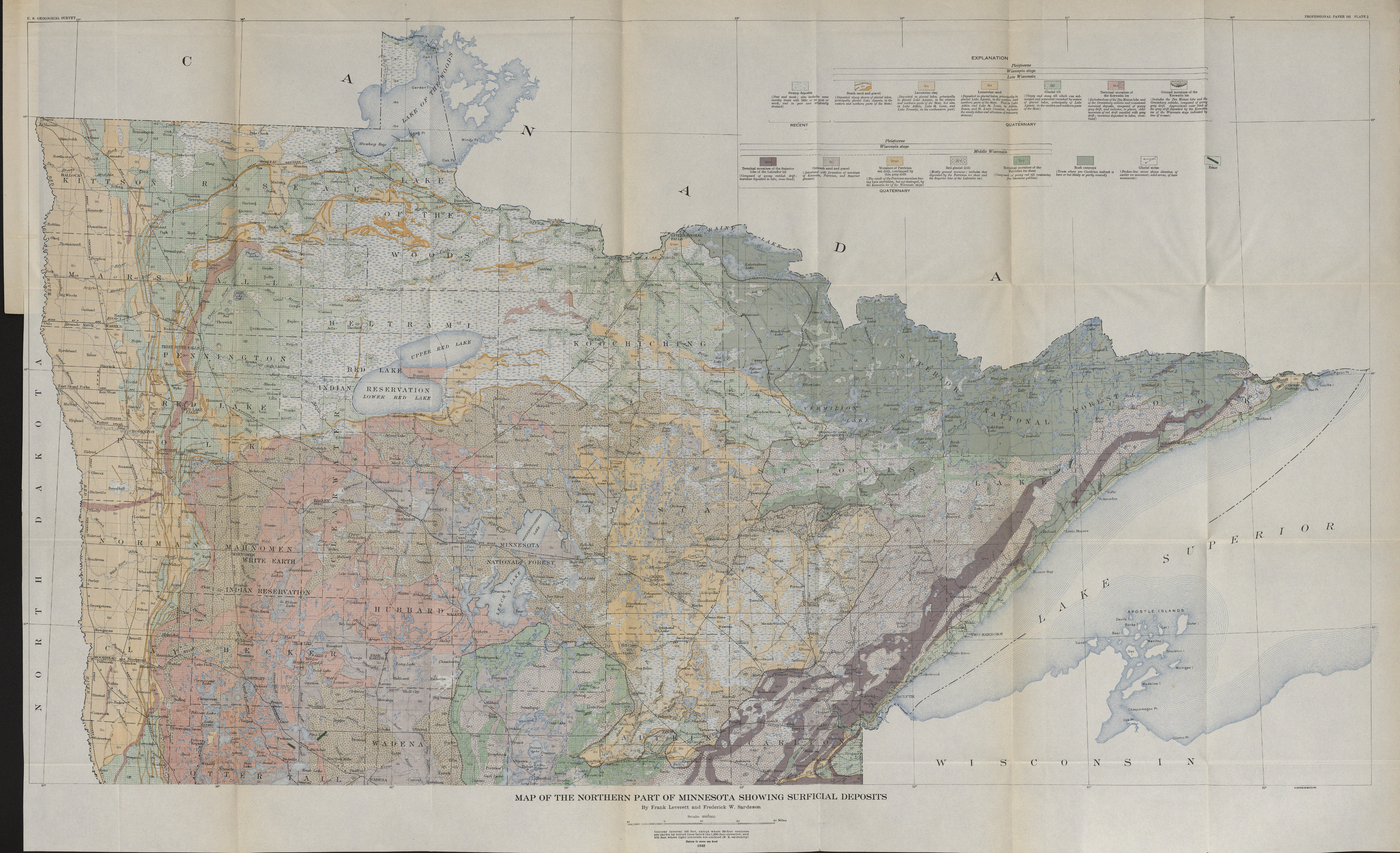





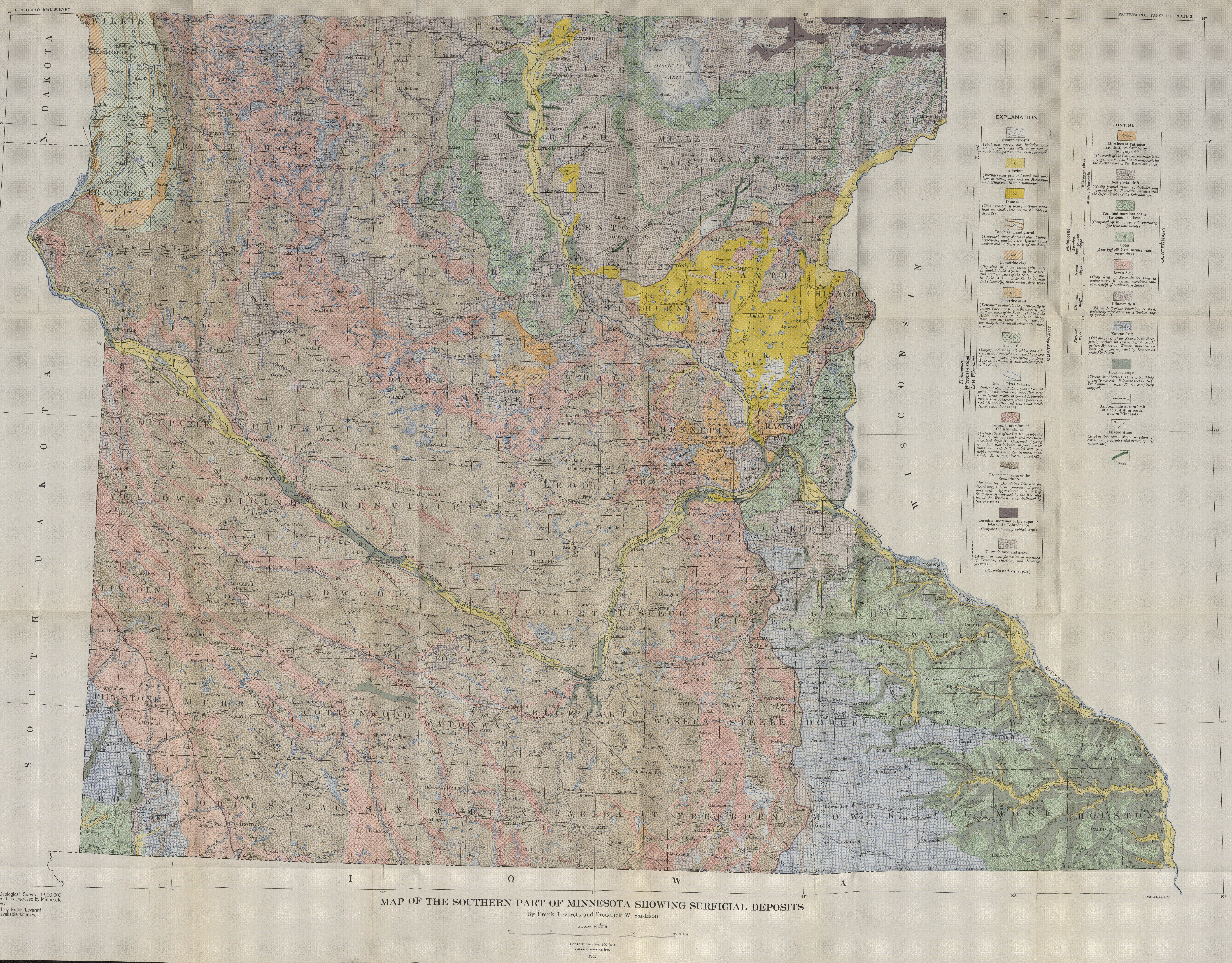





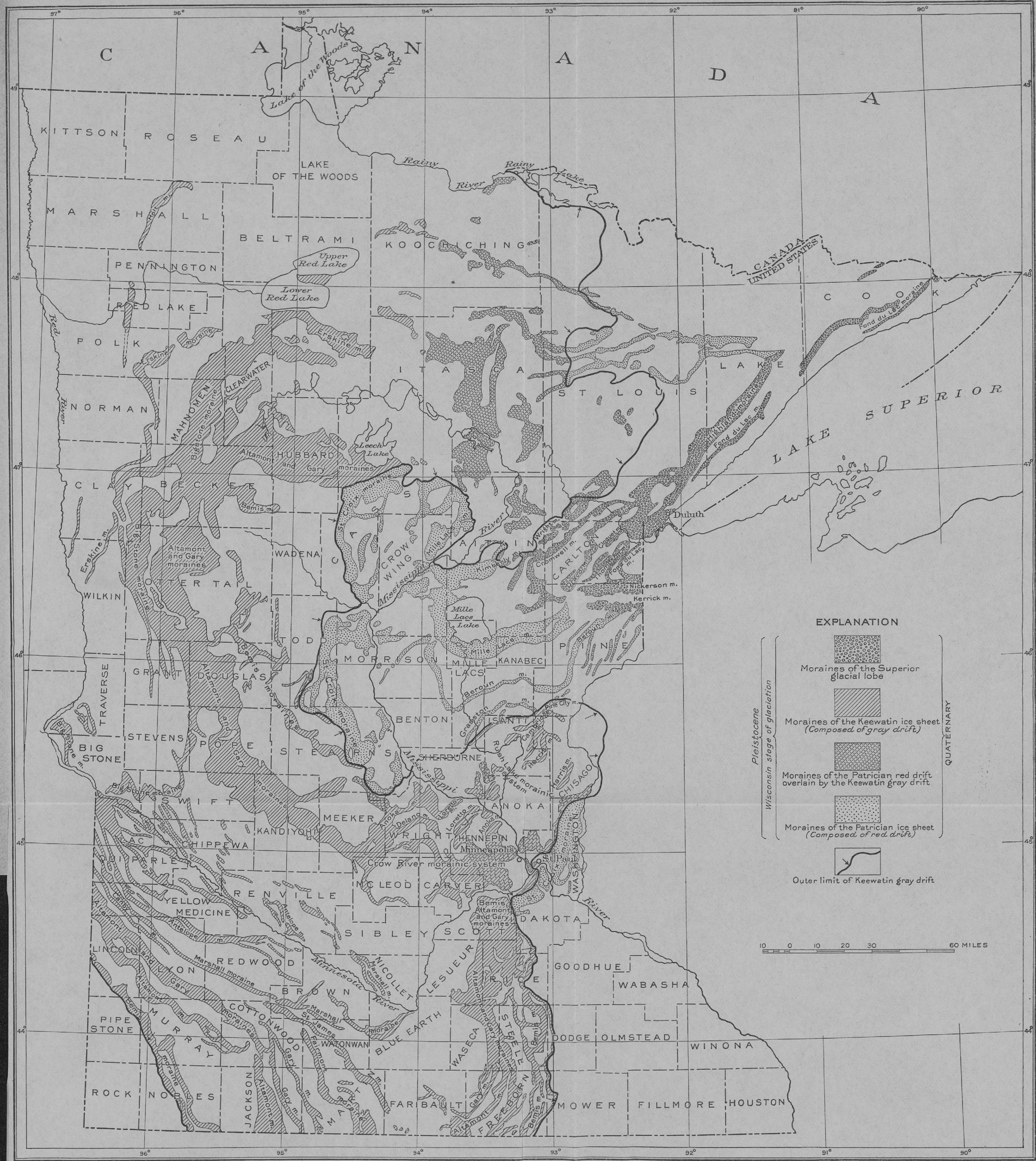

MAP OF MINNESOTA SHOWING THE RELATIONS OF THE MORAINES OF THE KEEWATIN ICE TO THOSE OF THE PATRICIAN ICE AND OF THE SUPERIOR LOBE OF THE LABRADOR ICE, ALL OF THE WISCONSIN STAGE OF GLACIATION 



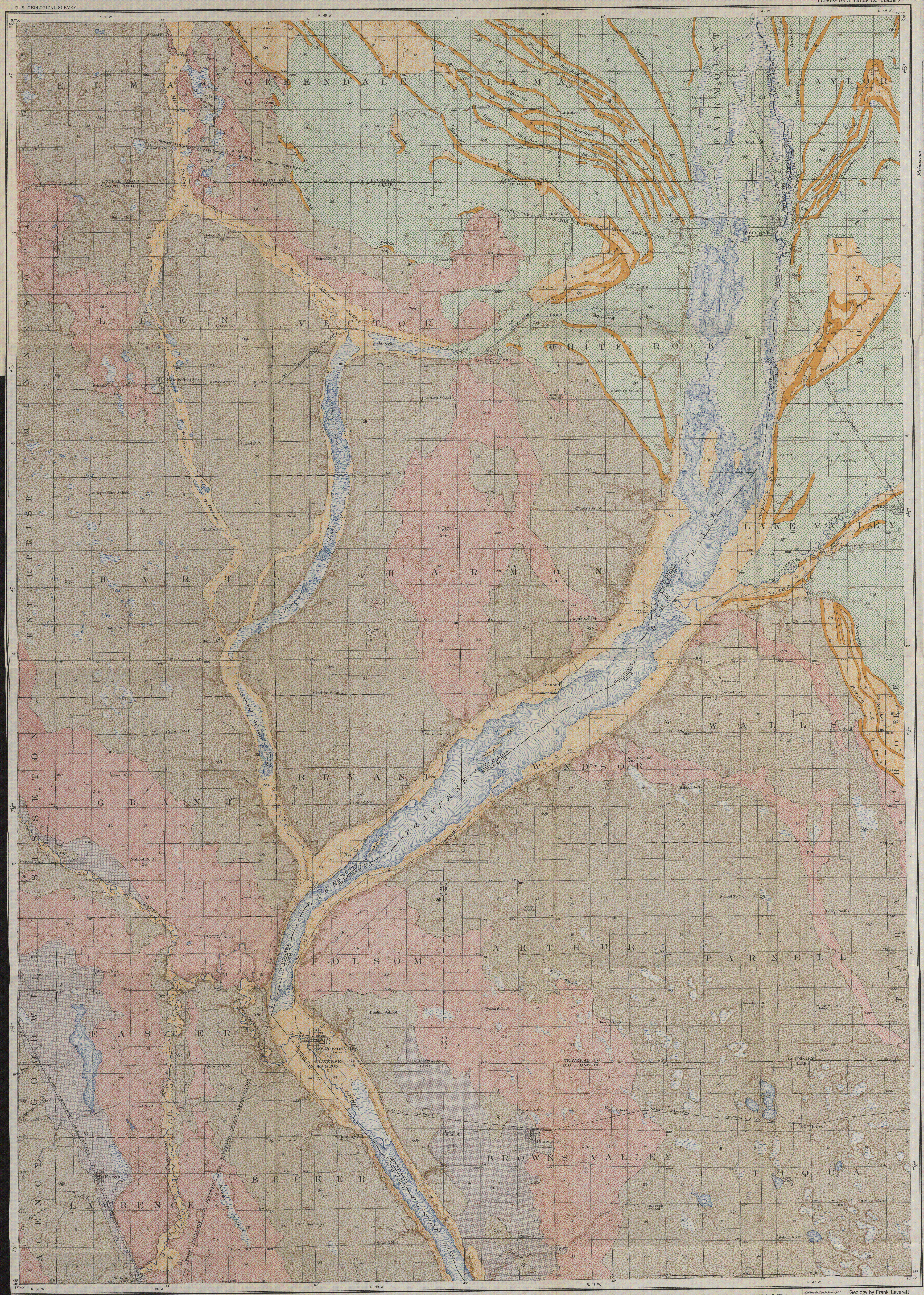




